BROWN
JUDAIC
STUDIES

\title{
Kol Nidre
}

Studies in the Development of Rabbinic Votive Institutions

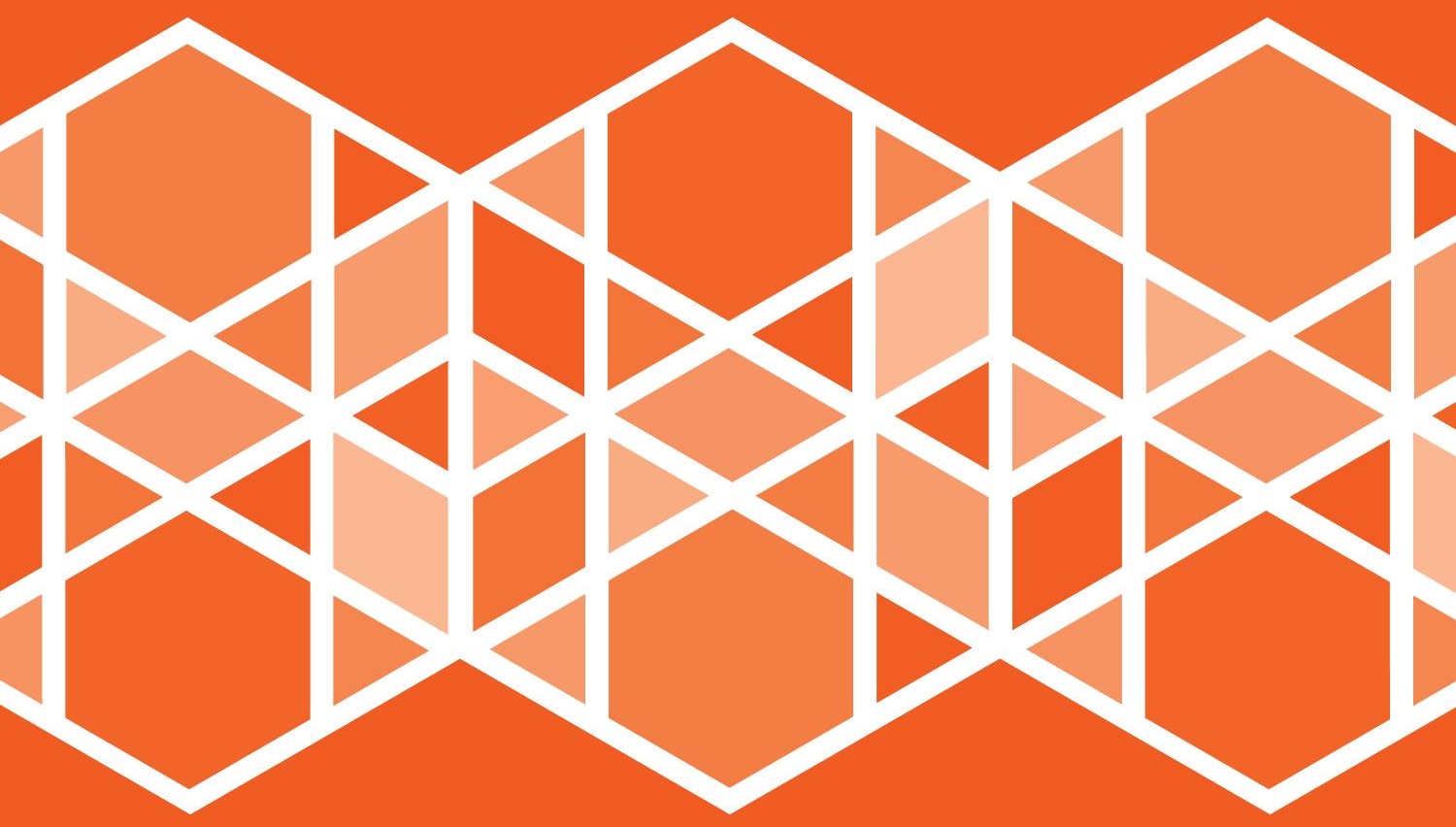

MOSHE BENOVITZ 


\section{KOL NIDRE}

Studies in the Development of

Rabbinic Votive Institutions 
Program in Judaic Studies

Brown University

BROWN JUDAIC STUDIES

Edited by

Shaye J. D. Cohen

Number 315

KOL NIDRE

Studies in the Development of

Rabbinic Votive Institutions

by

Moshe Benovitz 


\section{KOL NIDRE \\ Studies in the Development of \\ Rabbinic Votive Institutions}

by

Scholars Press

Atlanta, Georgia 


\section{KOL NIDRE \\ Studies in the Development of Rabbinic Votive Institutions}

by

Moshe Benovitz

Copyright $(92020$ by Brown University

Library of Congress Control Number: 2019953677

Open access edition funded by the National Endowment for the Humanities/Andrew W. Mellon Foundation Humanities Open Book Program.

The text of this book is licensed under a Creative Commons AttributionNonCommercial-NoDerivatives 4.0 International License: https:// creativecommons.org/licenses/by-nc-nd/4.0/. To use this book, or parts of this book, in any way not covered by the license, please contact Brown Judaic Studies, Brown University, Box 1826, Providence, RI 02912. 


\section{CONTENTS}

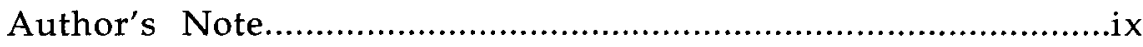

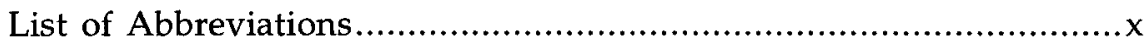

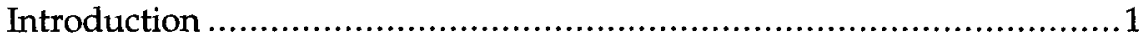

1 NEDER: The Origin and Meaning of the Post-Biblical

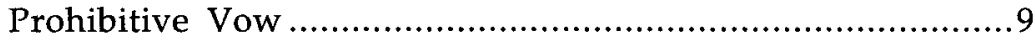

[1] Vows in the Hebrew Bible ......................................... 9

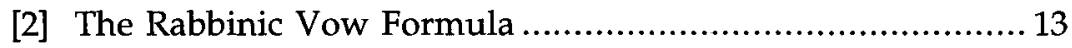

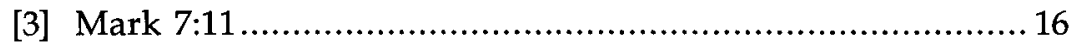

[4] The Kidron Valley Sarcophagus Inscription................... 27

[5] The Consecration of Food in the Damascus Document.......... 30

[6] The Vow in Philo's Hypothetica ..................................... 33

[7] The Prohibitive Vow in Tannaitic Literature.................... 35

2 ISSAR: A Term in Search of Meaning...........................................4 41

[1] Five Meanings of the Term Issar .................................. 41

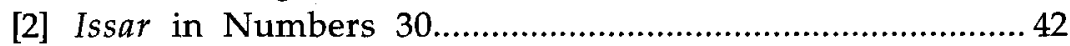

[3] The "Commemorative Days" Baraita ............................... 46

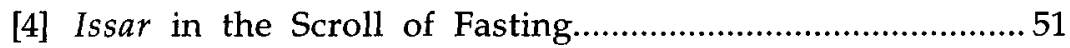

[5] The "Issar is an Oath" Baraita............................................ 55

[6] Amoraic Interpretations of the Term Issar ....................... 59

[7] Issar as the Standard Term for Vow in Fourth-Century

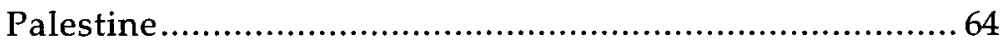

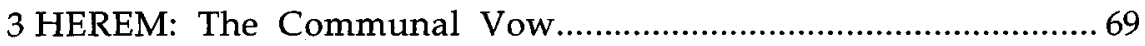

[1] Various Meanings of the Word Herem .............................6 69

[2] Herem as a Communal Wartime Offering ......................... 71

[3] The Herem in Pre-Deuteronomic Law and Narrative........... 75

[4] The Herem in Deuteronomy......................................... 79

[5] The Herem in the Priestly Literature ............................ 81

[6] The Herem of Persons in Second Temple Literature ............ 87

[7] Herem as a Ban on Social Intercourse............................. 95

[8] Excommunication at Qumran........................................100

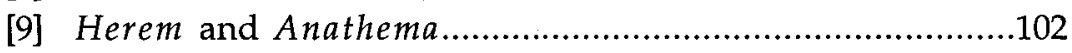

[10] Herem and Community ...............................................107 
4 QONAM, KINNUI, and QONAS: Substitute Vow Formulae........111

[1] The Kinnuyim of Mishnah Nedarim 1:2 ..........................111

[2] Qonam is not a Phoenician Term ..................................117

[3] Greek Koinon and Hebrew Qonam................................122

[4] The Transcription of Koinon, Koine, and Koinos .................125

5 SHEVUAH: Taking the Name of the Lord ...............................127

[1] The Biblical Executor-Type Oath Formula ......................127

[2] Divine and Human Executors.........................................131

[3] Ancient Greek Oath Formulae......................................132

[4] The Greek Model Cannot Explain Rabbinic Usage .............135

[5] Roman Oath Types and Rabbinic Usage ........................137

[6] Further Examples of Roman Influence............................139

[7] Rabbinic Surety-Type Sanction Oaths and

Doubly-Conditional Rabbinic Prohibitive Vows ................143

[8] The Divine Name in Rabbinic Oaths .............................145

6 HATARAT NEDARIM: The Dissolution of Vows.......................149

[1] Hatarat Nedarim and Lack of Proper Intent......................149

[2] Hatarat Nedarim as a Power Vested in the Rabbis............152

[3] The Evidence of Philo.................................................153

[4] Hatarat Nedarim Prior to the Destruction of the

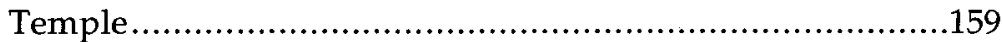

[5] Hatarat Nedarim in Talmudic Law..............................162

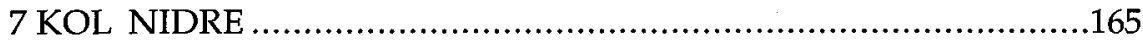

[1] The Origin and Development of the Kol Nidre

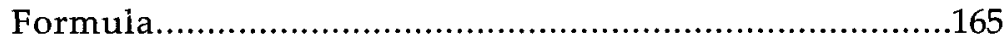

[2] Kol Nidre and the High Holy Days ..............................173

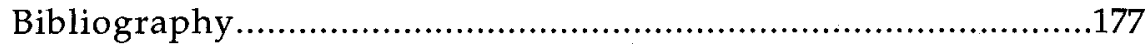

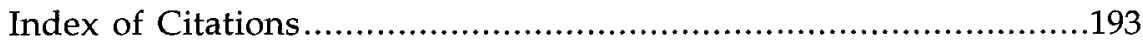




\section{Publishers' Preface}

Brown Judaic Studies has been publishing scholarly books in all areas of Judaic studies for forty years. Our books, many of which contain groundbreaking scholarship, were typically printed in small runs and are not easily accessible outside of major research libraries. We are delighted that with the support of a grant from the National Endowment for the Humanities/Andrew W. Mellon Foundation Humanities Open Book Program, we are now able to make available, in digital, open-access, format, fifty titles from our backlist.

Moshe Benovitz's KolNidre: Studies in the Development of Rabbinic Votive Institutions (1998) remains a foundational and original study of how the rabbis in antiquity understood vows and oaths. Benovitz puts these rabbinic discussions in both diachronic (with the Bible and later liturgical texts) and synchronic (with contemporary Greek and Roman discourse) contexts.

This edition contains typographical corrections of the original text.

Michael L. Satlow Managing Editor October, 2019 



\section{Author's Note}

\section{ברוך שהחיינו וקיימנו והגיענו לומן הזה.}

This book is dedicated to the memory of my student Matthew Eisenfeld ל"צi, whose beautiful life was so cruelly cut short in a terrorist attack in Jerusalem this past year. May his death move the Almighty and inspire us to turn the land of Israel,

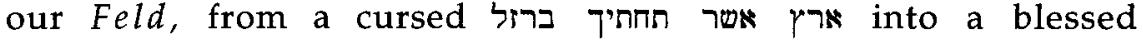
איד. ארי לא תחסר כל בה ארץ אשר אבניה ברזל

When this book was no more than a glint in its author's eye, Professor Shaye J.D. Cohen, editor of the Brown Judaic Studies series, asked me whether any part of my doctoral dissertation, a detailed Hebrew critical commentary on Chapter Three of BT Shevuot, dealing with personal oaths, was publishable in English. I replied that I did not think so, but that I had an idea for a general introduction to the history of the rabbinic laws of oaths and vows. He asked me to send in a proposal for publication, and thus Kol Nidre was born.

Three chapters of the book are based upon previous publications of mine. Chapter One was originally published in Hebrew in Tarbiz 64 (1995). Chapter Two is based upon my analysis of the second sugya of Chapter Three of BT Shevuot in my Ph.D. dissertation. A more detailed version of Chapter Four is forthcoming in Hebrew in Sidra 12. The other chapters were written expressly for this work.

I am deeply grateful to Professor Cohen for making this book possible and for his comments and suggestions. I am also indebted to my teacher, Professor Shamma Friedman, for his encouragement, assistance, and insightful contributions; and to my friend, Aaron Amit, and my wife Nancy, who both read the entire manuscript and offered valuable suggestions. In addition, I would like to thank the many people who read and commented on earlier versions of parts of the book: these include Professors Daniel Sperber and Elisha Qimron, and my friends David Frankel, Hillel Newman, and Adiel Schremer.

I further acknowledge the inspiration of the works of Professor Saul Lieberman of blessed memory, whose methodology, ideas, and pioneering work in the field of Oaths and Vows and their cultural context inform this work on every level, even in cases where I differ with his analyses.

The preparation of this work was carried out with the support of the Memorial Foundation for Jewish Culture.

Despite my debts of gratitude to all of the above, I take full responsibility for the ideas expressed in this work. As for any errors or proposals that may prove untenable, כלהון איחרטנא בהון כלהון יהון שרן, בטלין ומבוטלין, לא שרירין ולא קיימין.

Moshe Benovitz - Jerusalem, Erev Yom Kippur 5757 


\author{
Abbreviations \\ BT Babylonian Talmud \\ CAD Chicago Assyrian Dictionary \\ CDC Cairo (Geniza) Damascus Covenant \\ LCL Loeb Classical Library \\ LXX Septuagint \\ OCD Oxford Classical Dictionary \\ PT Palestinian Talmud
}




\section{Introduction}

The most popular prayer in the Jewish liturgy is also one of the most arcane. Jews all over the world assemble in synagogues as the holiest day of the Jewish year is ushered in, only to hear the cantor chant, three times, in Aramaic, a formula absolving them of all resolutions undertaken under the rubric of seven ancient votive institutions: nidrei, esarei, haramei, qonamei, kinnuyei, qinnusei, and shevu'ot. The precise meaning of these terms is unclear even to the foremost translators of the prayer book into English, who for the most part substitute a shorter list of general terms such as "vows, oaths, and pledges," or the like. ${ }^{1}$ These translators are in good company. Rav Natronai Gaon of eighth-century Babylonia attests that in his day the laws of vows had not been studied in Babylonia for over one hundred years. ${ }^{2} \mathrm{He}$ cites one of his predecessors, Rav Yehudai Gaon, one of the most eminent rabbinic scholars of the seventh century, as follows:

And Rav Yehudai Gaon, light of the world, said as follows: we do not study Nedarim [the talmudic tractate that deals with vows], nor do we

\footnotetext{
${ }^{1}$ So Birnbaum 1951:490: "All personal vows we are likely to make, all personal oaths and pledges we are likely to take...." Birnbaum justifies this paraphrase in his introduction (1951:xvi) as follows: "The Kol Nidre passage...contains words like konam and konas, used as substitutes for the word korban ("sacrifice") to express a self-imposed vow. Synonyms such as these cannot of course be translated literally." While this may very well be the case, it is not clear that Birnbaum himself was aware that a herem is not a personal vow, oath, or pledge, but a communal vow or resolution (see Chapter 3 below). Other translators translate qinnusei "penalties" (see Birnbaum 1951:xvi), apparently unaware that the term is derived from (see Chapter 4 below), not oup, "penalty." Moreover, neither Birnbaum nor most other translators see fit to explain, whether in a note or in the introduction, the difference between the various terms included in their abridged list, e.g. the difference between an oath and a vow. It is clear that the exigencies of translation can account only in part for the liberties taken by the translators of the prayer book in their treatment of Kol Nidre.

${ }^{2}$ See below, Chapter 7, section 1, and note 8 there.
} 
know how to rule strictly or leniently in this area, neither regarding oaths nor regarding vows. ${ }^{3}$

The laws of vows also engendered confusion among ancient Christians. The church father Origen terms a votive practice cited in the New Testament asaphestaron, "rather obscure." Contemporary scholars studying Second Temple Judaism and early Christianity also often write that ancient texts dealing with oaths and vows are obscure or unclear. ${ }^{5}$ In large measure, this is due to the fact that to this day there is no introduction to the laws of oaths and vows in the Bible, Talmud, and ancient Judaism. This volume is designed to address that need.

The seven votive institutions mentioned in the Kol Nidre prayer: neder, issar, herem, qonam, kinnui, qonas and shevu'ah, are not mere synonyms. Each has a history and a meaning of its own. Most originated in biblical times, and evolved throughout the Second Temple period before achieving their final form in rabbinic literature. The sheer number of terms would indicate that such institutions were widely used in ancient Israel, and, indeed, a number of tractates of the Talmud, among them Nedarim, Shevuot, and Arakhin, are devoted to these institutions alone. Unfortunately, these tractates are still not widely studied, and the obscure nature of the subject is the cause of much confusion when contemporary scholars encounter oaths or vows in Second Temple sources and in rabbinic literature. ${ }^{6}$

This book is conceived as an English introduction to the laws of oaths and vows of various types as they appear in biblical, Second Temple, and rabbinic sources. It should be noted that no comparable work exists in Hebrew or English. From the methodological point-ofview, the present work differs significantly from the little scholarship that does exist on the subject. Previous scholarship has tended to interpret obscure references to votive institutions in Second Temple texts in light of the dominant rabbinic conceptions expressed in the Mishnah and Talmud. ${ }^{7}$ It is my belief, however, that these institutions developed over time, and that pre-rabbinic sources represent an interim stage between biblical and rabbinic usage of votive terminology. These sources should not be understood in light of subsequent rabbinic development; on the contrary: it is precisely the Second Temple texts, however obscure

\footnotetext{
${ }^{3}$ Lewin 1942, volume 11:22-23. See also references cited below, Chapter 7, note 8 . 4See below, Chapter 4, section 3, and references cited in notes 53-54 there.

${ }^{5}$ See below, Chapter 1 , section 3 , and references cited in note 22 there.

${ }^{6}$ See previous note, and see also references cited below in Chapter 1 , notes 1,16 , $23,24,36,45$ and 56.

${ }^{7}$ See examples cited immediately below.
} 
they may be, that provide the clues toward understanding the evolution of these institutions in rabbinic literature.

The first five chapters of the book are devoted to the institutions mentioned in the Kol Nidre prayer: neder, issar, herem, qonam/kinnui/gonas, and shevu'ah. The terms neder, issar, herem and shevi ah are of biblical origin, and the chapters devoted to these terms begin with an extensive treatment of the biblical usage or usages, followed by an analysis of the development of these usages during the Second Temple and rabbinic periods. Neder, herem and shevi 'ah are biblical votive institutions. The use of the terms neder and shevu ah in the Bible is relatively straightforward, while the term herem, by contrast, is used in a number of different senses in the various strata of biblical literature. Issar in the Bible is not a votive institution in its own right at all; it is simply a word meaning obligation used in conjunction with the word shevu ah. It is only in rabbinic literature that the term issar takes on technical meanings of its own. Qonam, kinnui and qonas are institutions that originated in the rabbinic period, and the chapter devoted to these terms focuses on their etymology and origin.

The term neder, "vow," is used in two senses in rabbinic literature. A dedicatory vow is a promise to devote something or someone to the Temple; a prohibitive vow is a ban placed on a specific property, barring its use by the votary himself or by another person mentioned in the vow. A votary can either devote his property to the Temple outright, or liken his property to dedicated property with formulae such as "qorban ('offering') is that which I/so-and-so shall eat," prohibiting its use as if it were an offering. The Rabbis conceived of both of these as biblical institutions. $^{8}$

Contemporary scholarship has taken the rabbinic conception at face value. Numbers 30 is often interpreted by modern scholars as referring to prohibitive vows, in the wake of rabbinic interpretation. ${ }^{9}$ References to prohibitive vows in the Damascus Document, ${ }^{10}$ Philo, ${ }^{11}$ the New Testament, ${ }^{12}$ and an ossuary inscription discovered in the Kidron Valley ${ }^{13}$ are interpreted by most scholars as rabbinic-type prohibitive vows, in which the banned object is likened to a Temple offering without actually being donated to the Temple. ${ }^{14}$ Following the rabbis, scholars

\footnotetext{
${ }^{8}$ See below, Chapter 1 , section 1 .

${ }^{9}$ See Chapter 1 , note 1 , below.

${ }^{10}$ CDC XVI, 13-15. See below, Chapter 1, section 5.

${ }^{11}$ Philo, Hypothetica, cited in Eusebius's Praeparatio Evangelica VIII, 7.3-7.5 (LCL, Philo, volume 9, pp. 424-427). See below, Chapter 1, section 6.

${ }_{12}$ Mark 7:11, Matthew 15:5. See below, Chapter 1, section 3.

${ }^{13}$ See below, Chapter 1, section 4 .

${ }^{14}$ See references cited below in Chapter 1, notes 25, 45, 55 and 56.
} 
assume that this type of vow is of biblical origin, and therefore are not surprised to encounter it in Second Temple sources. They often note, however, that the texts themselves are obscure, and seem to indicate that an actual offering to the Temple may be contemplated. ${ }^{15}$

In fact, the prohibitive vow is nowhere mentioned in the Bible. Biblical vows are all dedicatory. ${ }^{16}$ The notion of likening property to an offering is quite strange in its own right. Moreover, analysis of the formulae used in prohibitive vows in both Second Temple and rabbinic literature suggests that originally, prohibitive vows were actually dedicatory vows of a specific type, which could not take effect for technical reasons. The only practical effect was a personal prohibition. These vows represent a transitional stage between the biblical dedicatory vow and the rabbinic vow likening property to an offering. This type of vow was apparently originally conceived as an oath substitute. Oaths were avoided by the populace and discouraged by the Rabbis because they involved the use of God's name, and, in the words of the Decalogue, "the Lord will not acquit him who takes his name in vain." 17

The term issar in the Bible simply means obligation or promise. ${ }^{18}$ It is used only in conjunction with the term shevi ah, "oath," 19 in order to distinguish a future-tense promissory oath from a past-tense asseverative oath. In rabbinic literature the term issar is used and defined in a number of different ways. In the Palestinian Talmud it refers primarily to a prohibitive vow of the type discussed above, but not all the references to issar in PT are easily interpreted in this light. ${ }^{20}$ The term was clearly not in use at all in Babylonia, and thus the fourth-century scholars Rava and Abaye have no choice but to offer their own conjectures as to its meaning. ${ }^{21}$

Once again, a Second Temple source provides the link between biblical and rabbinic usage. The Scroll of Fasting, a proto-rabbinic document from the Second Temple period, mentions the term issar. ${ }^{22} \mathrm{~A}$ reading unprejudiced by later rabbinic usage would indicate that in the Scroll of Fasting issar is used in yet another sense: it is a solemn promise to undertake a fast. This promise is binding even if no votive terminology is used, and therefore it is referred to by the biblical word issar, "promise." Once we have established that this meaning is the one

\footnotetext{
${ }^{15}$ See references cited below in Chapter 1 , note 22 .

${ }^{16}$ See below, Chapter 1, section 1 .

${ }^{17}$ See below, Chapter 1, at the end of section of 3 , and note 33 there.

18 See below, Chapter 2, section 2 .

${ }^{19}$ Numbers 30:3-15.

${ }^{20}$ See below, Chapter 2, sections 5 and 6 .

${ }^{21}$ BT Shevuot 20a. See below, Chapter 2, section 6.

${ }^{22}$ See below, Chapter 2, section 4 .
} 
attested in pre-rabbinic sources, it becomes clear that it lies behind tannaitic and early amoraic usage as well. It is only toward the end of the third century that the custom of undertaking a fast with an issar fell into disuse, and at that point the amoraim began to suggest other interpretations of the term, reading those interpretations into earlier sources as well. ${ }^{23}$

The term herem is used in the Bible in a number of senses. At root, a herem was a communal dedicatory vow. A herem is the dedication to the Lord as an offering of communal property or of human beings whose lives are declared forfeit by the community either in the context of war or as a punitive measure. ${ }^{24}$ People and property declared herem become sacred, and their sanctity is contagious: anyone who touches them becomes herem himself. ${ }^{25}$ Thus the salient feature of herem property is the fact that it is off-limits. In rabbinic literature, however, the term herem is used primarily in the sense of "excommunication," without any inherent sanctity, and the link between this herem and the biblical herem has not been satisfactory explained by scholars and lexicographers. ${ }^{26}$ Here, too, Second Temple literature provides the missing link: there are a number of references to communal haramim in Second Temple texts, ${ }^{27}$ in which a group of confederates bind themselves to carry out a certain plan, declaring anyone who shirks their responsibility to the group herem. Each member of the group consents in advance to become herem in the event that he shirks his responsibility, and the penalty is thus death as an offering to God. Since the herem victim's sanctity (and condemnation) was contagious, no one would have been permitted to come into contact with him unless and until the herem was carried out. When actual sacrifice of the victim became impossible or impractical, the contagion remained the sole effect of the herem. This practice, coupled with the fact that in Akkadian the verb haramu (etymologically unrelated to the Hebrew herem) means "cut off," gave rise to the use of the term herem in rabbinic Hebrew and Aramaic in the sense of excommunication. ${ }^{28}$

As we have seen, the prohibitive vow probably originated as a substitute for the oath formula. In rabbinic times, even the vow formula was shunned, and the people began to use substitute terms (kinnuyim) that sounded like the Hebrew words for vow, herem, oath, and other authentic votive terminology instead. Mishnah Nedarim 1:2 lists substitute formulae for vows, oaths, bans, and the undertaking of

\footnotetext{
${ }^{23}$ See below, Chapter 2, sections 5 and 6 .

${ }^{24}$ See below, Chapter 3, sections 2, 3, and 4.

${ }^{25}$ See below, Chapter 3, sections 3 and 4 .

26 See below, Chapter 3, section 1 .

${ }^{27}$ See below, Chapter 3, section 6 .

${ }^{28}$ See below, Chapter 3 , sections 7,8 , and 9.
} 
naziriteship. The Talmud records a debate as to whether these substitute terms are nonsense words that sound like the authentic terms, or foreign language terms. ${ }^{29}$ Neither view is entirely correct from the historical point of view: each of the substitute terms has a history of its own, and each must be studied in its own right. ${ }^{30}$

The original formula of the prohibitive vow was "qorban the food that I shall eat," which was interpreted by the Rabbis to mean that the food is likened to a qorban, or offering. The substitute formulae for qorban listed in the Mishnah are qonam, qonah, and qonas (the first and last being the qonamei and qinnusei of the Kol Nidre prayer). ${ }^{31}$ Most scholars view the term qonam as a variant of a Phoenician oath formula $\mathrm{gnm}$ found in the Eshmunazar inscription of the fifth century B.C.E., ${ }^{32}$ while qonah and qonas are seen as nonsensical substitute formulae for qonam. ${ }^{33}$

However, these scholars have failed to explain adequately how an obscure and ancient Phoenician term found its way into rabbinic literature, especially in a catalogue of vow formulae that clearly originated in popular usage. Moreover, an alternate definition of the Phoenician term has nothing to do with oaths or vows, and it would seem that the meaning "oath" is informed largely by rabbinic usage. In this work a new etymology of qonam is proposed: it is a transliteration of the Greek word koinon, "common," which was used by the Jews of Palestine during the Second Temple period in the sense of "alms," donations to the "common fund." 34 Once again, Palestinian reality of the Second Temple period is seen as the background against which a rabbinic institution developed. The development of substitute formulae is explained as a response to the destruction of the Temple, and the ensuing change in the mechanics of the prohibitive vow. ${ }^{35}$

The last of the institutions mentioned in Kol Nidre is shevu $a h$, "oath." The theoretical basis of this institution remained the same throughout biblical, Second Temple, and rabbinic times: an oath is a curse or imprecation which the swearer invokes upon himself if he is lying. In form, however, the oath underwent significant development. In biblical oath formulae the curse itself is usually left unstated, being too horrible to mention, but God's name is invoked, the intention being to call upon God to punish the swearer as he sees fit. ${ }^{36}$ This is in keeping

\footnotetext{
${ }^{29}$ BT Nedarim 10a. See also below, Chapter 4 , note 9.

${ }^{30}$ See below, Chapter 4 , section 1 .

${ }^{31}$ See below, Chapter 4 , note 1 .

${ }^{32}$ See below, Chapter 4 , section 2 , and note 27 there.

${ }^{33}$ See below, Chapter 4 , note 30 .

${ }^{34}$ See below, Chapter 4, sections 3 and 4 , and references cited in note 55 there.

${ }^{35}$ See below, Chapter 4, section 3 .

${ }^{36}$ See below, Chapter 5, section 1 .
} 
with ancient near Eastern practice. ${ }^{37}$ The Rabbis insisted in theory that God's name be invoked in every oath, ${ }^{38}$ but in the citations of oaths in rabbinic literature, the term shevu'ah itself, preceding a declarative statement, is used instead of a curse and instead of God's name. ${ }^{39}$ In oaths recorded in rabbinic dialogue, on the other hand, a substitute for God's name is often invoked. ${ }^{40} \mathrm{~S}$. Lieberman has sought to explain these developments in light of classical Greek usage, ${ }^{41}$ but it is the contention of this author that the formulae current during the rabbinic period have their analogues in Roman, rather than Greek, practice. ${ }^{42}$

In the Bible oaths and vows were considered absolutely sacred and inviolable. Rabbinic literature, however, devotes considerable attention to the dissolution of vows: sages and rabbinical courts were somehow empowered to declare vows, and according to some, oaths as well, not binding. ${ }^{43}$ The last two chapters of the book are devoted to this issue.

This dissolution of vows is usually seen as a type of annulment: the sage in his wisdom finds a loophole in the original vow which renders it not binding $a b$ initio. ${ }^{44}$ This interpretation, however, fails to account for the rapid development of the practice into a nearly automatic power granted the sages or the courts to annul any and all vows, even on extremely dubious grounds. Once again, a Second Temple source provides the key to uncovering the true origin of the institution. Philo alludes to the fact that the power granted to men of authority to dissolve vows is rooted in the procedures enacted in the Temple treasury during Temple times: the treasurer of the Temple, or his agent, had the authority to reject an offering on God's behalf. ${ }^{45}$ Since even a prohibitive vow was originally a type of conditional dedicatory offering that had not yet taken effect, ${ }^{46}$ Temple treasury officials or influential lay people acting on their behalf could "reject" the donation at the request of the votary himself, rendering a prohibitive vow no longer binding. ${ }^{47}$

Nowhere in talmudic literature, however, do we read of the dissolution of vows en masse without a personal interview, in the manner

${ }^{37}$ See below, Chapter 5 , section 2 .

${ }^{38}$ Mishnah Shevuot 4:13; see below, Chapter 5, section 8 . But see reference cited in notes $99,104-105$ there.

${ }^{39}$ See below, Chapter 5 , section 8 .

${ }^{40}$ See examples cited in Chapter 5, notes 101 and 102.

${ }^{41}$ Lieberman 1942:115-141.

42 See below, Chapter 5, sections 5, 6, and 7 .

${ }^{43}$ See Mishnah Nedarim, Chapters 3 and 9, and see below, Chapter 6, section 1.

${ }^{44}$ See below, Chapter 6, section 1, and references cited in notes 11 and 12 there.

${ }^{45}$ Philo, Hypothetica, cited in Eusebius's Praeparatio Evangelica VIII, 7.5 (LCL, Philo, volume 9, pp. 426-427).

46 See above, in the introduction, and Chapter 1 below.

${ }^{47}$ See below, Chapter 6 , sections 3 and 4 . 
of Kol Nidre. The last chapter of this work deals with the Kol Nidre formula itself: how and why did the dissolution of vows come to be connected with Yom Kippur? And how did it develop from a personal appeal to a sage or tribunal into a blanket declaration that all vows, oaths, issarin, haramin, and substitute formulae are not binding? Unlike the various votive institutions themselves, which have suffered neglect by scholars both ancient and modern, the Kol Nidre prayer has been treated by many scholars over the past hundred years. ${ }^{48}$ Various theories have been proposed concerning the provenance and date of the original Kol Nidre formula, as well as its halakhic status and its connection with the high holy day season. ${ }^{49}$ These theories are discussed and evaluated anew in the final chapter. ${ }^{50}$

The work as a whole is conceived both as a description of the history of votive institutions in ancient Israel, as well as an introduction to the voluminous rabbinic literature on the subject. As such, it is my hope that it will be of use and interest to historians, historians of ideas, and students of biblical and rabbinic literature.

\footnotetext{
${ }^{48}$ See bibliographies in references cited below, Chapter 7, notes 6 and 16 .

${ }^{49}$ See below, Chapter 7, section 1 .

${ }^{50}$ See below, Chapter 7, section 2 .
} 


\section{1}

\section{NEDER: The Origin and Meaning of the Post-Biblical Prohibitive Vow}

\section{[1] Vows in the Hebrew Bible}

Prohibitive vows are nowhere mentioned in the Hebrew Bible. The term neder, "vow," is used solely to refer to the dedication of persons or property to God. ${ }^{1}$ The biblical vow is usually conditional: ${ }^{2}$ Jacob vows a tithe to God, if God will watch over him on his journey (Genesis 28:2022). Hannah offers her son to the divine service, if God will give her a son (I Samuel 1:11). The Psalms often refer to vows fulfilled in the wake of a positive response to the votary's prayer, which is the condition upon which the vow was predicated. ${ }^{3}$ The laws of vows are discussed in Leviticus 27: one can devote either an animal fit for sacrifice or other property. Sacrificial animals are offered upon the altar, while other consecrated property is turned over to the Temple treasury, and is

\footnotetext{
${ }^{1}$ See Milgrom 1990:488-489. This is also evident from a reading of the texts themselves. Some scholars nonetheless find allusions to prohibitive vows in certain biblical passages. Haran (1968:787-790), for example, cites three examples of biblical prohibitive vows: (1) the vows discussed in Numbers 30 along with "oaths obligating self-denial;" (2) David's vow in Psalm 132:2, which is mentioned in parallelism with an oath of self-denial; and (3) the vow of the Nazirite in Numbers 6:1-21. However, as we shall see immediately below, Numbers 30 according to the plain meaning of the text treats dedicatory vows, as well as oaths of self-denial. David's vow is a vow to dedicate a site for the restingplace of the ark; at the same time he swears an oath of self-denial, to refrain from sleeping at home until his vow is fulfilled. The Nazirite dedicates his own person to the divine service.

${ }^{2}$ According to Milgrom 1990:488-489, the biblical vow is always conditional. This may be correct, although I Samuel 1:21 and Jonah 1:16 could be taken to indicate that vows were taken as a matter of course, during worship, and not necessarily in the context of a specific petition.

${ }^{3}$ Psalm $22: 26 ; 56: 13 ; 61: 6-9 ; 116: 17-18$, to cite but a few occurrences.
} 
considered sacred until it is sold by the Temple treasury to a third party or redeemed by the votary at cost plus one-fifth. Both the sacrificial and non-sacrificial types of consecration are referred to as qorban, "offering," in Second Temple literature, ${ }^{4}$ although the term is most commonly used to denote a sacrificial offering.

The biblical vow is thus a ritually binding declaration obligating the votary to give something to God. ${ }^{5}$ One can render commitments other than pledges to the Temple ritually binding by means of the שבועת אסר, or "oath of obligation"6 (Numbers 30:14), which the Rabbis refer to as the "future-tense oath of utterance." These oaths are commitments to do, or not to do, anything at all. A special type of future-tense oath of utterance/obligation is the "oath obligating self-denial" (Numbers $30: 14)$, by means of which a person undertakes a self-imposed prohibition as a private act of religious devotion, in addition to the negative commandments binding on all Israel. There are a number of examples of this in the Bible, such as the Israelites' oath not to eat until Saul is avenged (I Samuel 14:24), and David's oath not to sleep at home until a resting-place is found for the ark (Psalm 132:1-5).

The biblical vow in effect transfers the ownership of the devoted property from the votary to the Temple. ${ }^{7}$ Non-fulfillment engenders liability for trespass against Temple property. ${ }^{8}$ The consequences of

\footnotetext{
${ }^{4}$ For a qorban that is not a sacrificial offering, see Numbers 31:50, and see BT Yoma 63b. In Matthew 27:6 and Josephus, War II, 175, the Temple treasury is referred to as korbanas.

${ }^{5}$ One can also dedicate persons, in which case their financial value is donated to the Temple. See Leviticus 27:1-9; for a different system of evaluating the worth of the person dedicated, see Mishnah Arakhin, Chapter 5. The vow of the Nazirite is also a form of self-dedication; he devotes himself to the divine service by fulfilling the special obligations of the Nazirite, including the offering of sacrifices at the end of the period of his Naziriteship.

${ }^{6}$ For the term issar, "obligation," see Chapter 2 below. In Numbers 30 the term means "obligation," positive or negative, and not "prohibition." See Weinfeld 1975:123.

${ }^{7} \mathrm{Cf}$. Mishnah Qiddushin 1:6: "A pledge to heaven is tantamount to [physical] transfer to a commoner." This rabbinic notion is assumed in Scripture as well. Throughout Leviticus 27, it is assumed that if the votary wishes to release his property from its consecrated state he must redeem it from the Temple treasury, even if he has not yet given it over physically. From Leviticus 27:10 it is clear that the sacrificial animal is considered Temple property even before it is physically given over; therefore, if the votary switches the animal before transfer, both are considered consecrated.

${ }^{8}$ This is the case if one vows a specific item. If one simply pledges to give an offering, without earmarking a specific animal or possession, he is in violation of a negative commandment if he does not fulfill his pledge within a reasonable amount of time (Deuteronomy 23:22).
} 
violation of an oath, by contrast, are built in to the oath itself: an oath is a curse invoked upon the swearer in the event that the oath is violated. In the biblical oath formula, the curse is usually not explicit. Instead, some form of the divine name is usually invoked, by which the swearer indicates that God will exact punishment in case of violation. ${ }^{9}$

The Rabbis were of course familiar with both the biblical vow and the biblical oath. In addition, however, they knew of a third institution: the prohibitive vow. The talmudic tractate Nedarim, "Vows," deals almost exclusively with this type of vow. A prohibitive vow bars the votary or another person named in the vow from deriving benefit from a given possession. The property itself remains the possession of the votary, and is not transferred to the Temple treasury.

Prohibitive vows are usually explained in talmudic and posttalmudic halakhic literature as likening the banned object to Temple property..$^{10}$ According to this explanation, the votary declares that a given possession is (כ), "(like) an offering," and just as benefit from a Temple offering is forbidden to commoners, so the prohibited property is "off limits." In rabbinic literature, the substitute formula qonam usually takes the place of the formula 1 pב(כ). ${ }^{11}$ Mishnah Nedarim 7:6, for example, refers to the vow "this produce is qonam upon me," which is usually understood to mean: this produce is unto me like an offering, i.e., prohibited to me like an offering. Prohibitive vows are commonly referred to in the Talmud as qonamot, because of the qonam formula. ${ }^{12}$ Like the biblical oath of self-denial, the gonam vow is a personal prohibition. However, the subject of the vow is not the votary but the object prohibited, which changes its status, and becomes "forbidden." As we shall see below, the prohibitive vow was probably originally used as

The penalty for unwitting trespass against Temple property is specified in Leviticus 5:14-16. The penalty for willful trespass is not specifically mentioned in the Bible. Two views are recorded in Tosefta Zevahim 12:17: according to Rabbi trespass is a capital crime, while according to the Sages it is a simple negative commandment, presumably punishable by flogging. See also Joshua 7:25; Philo, De Specialibus Legibus III, 83, and the citation from his Hypothetica, below, section 6; Josephus, Antiquities V, 1 and Mishnah Sanhedrin 9:6. See also Chapter 3, note 43.

${ }^{9}$ For a discussion of biblical oath formulae, see Chapter 5 , sections 1 and 2, below, and references cited there, notes 3-5.

${ }^{10}$ See Mishnah Nedarim 1:3-4; Sifre Bemidbar, 153; PT Nedarim 1:4 (37a); BT Nedarim 14a. See discussion immediately following and at the end of this Chapter. This is also the way prohibitive vows were understood in rabbinic literature throughout the centuries. See Tur and Shulhan Arukh, Yoreh De'ah 204 , and commentaries ad loc.

${ }^{11}$ Mishnah Nedarim 1:2, and Chapter 4 below.

${ }^{12}$ So in BT. In PT, the common term for prohibitive vows is issarin/issarot. See Chapter 2, section 7, below. 
an oath substitute. Oaths were generally avoided because of the dire threat in the Decalogue (Exodus 20:7): "The Lord will not clear one who swears falsely by his name."

Despite the fact that the prohibitive vow is not mentioned explicitly in the Hebrew Bible, the Rabbis considered it a biblical institution, with the status of Torah law. Although all the specific examples of vows in the Bible are dedicatory vows, the Rabbis interpreted the word "vow" in Numbers 30 (and only in this chapter) as referring to prohibitive vows. Numbers 30:3, which reads:

If a man vows $a$ vow to the Lord, or takes an oath imposing an obligation upon himself, he shall not break his word; he must carry out all that has crossed his lips,

This is considered the Torah prohibition against violating a prohibitive vow. In BT Nedarim 14a this verse is said to refer to a vow likening a prohibited object to Temple property: "vows a vow to the Lord' - he must vow by something that is vowed [to the Lord]" i.e. liken the banned object to another object vowed to the Lord..$^{13}$ According to this exegesis, a dedicatory vow is a 'vow to the Lord', while the cognate accusative syntactical construction 'vow a vow to the Lord', entailing as it does the double usage of the word "vow," implies a secondary vow that is "linked" to the dedicatory vow. The same conception apparently lies behind the parallel comment on the same verse in the tannaitic Midrash Sifre Bemidbar, 153: "If a man vows a vow to the Lord' - when one juxtaposes a vow to something (im)possible to him, this is a vow." The exact meaning of this comment is unclear, ${ }^{14}$ but the most likely explanation is that the "something impossible to him" is a sacrificial offering.

Needless to say, this interpretation of Numbers 30:3 is far-fetched. The most obvious interpretation is that the "vow to the Lord" of this verse is none other than the dedicatory vow known throughout the Hebrew Bible. And indeed, the early tannaitic Midrash Sifre Zuta, which is known to preserve unique traditions, ${ }^{15}$ rejects the mainstream rabbinic interpretation cited above in favor of the plain meaning of the text:

"If a man vows a vow" - Does this perhaps refer both to a vow that involves consecration to the Lord and to a vow that does not involve consecration to the Lord? Scripture teaches: "to the Lord" a vow that involves consecration to the Lord.

\footnotetext{
${ }^{13}$ See also BT Nedarim 13a; BT Shevuot 20b.

${ }^{14}$ For a detailed discussion see Benovitz 1995:206, note 18.

${ }^{15}$ See Lieberman 1968:64-74. Of special interest to us are the examples of stringent (and presumably early) halakhot regarding trespass against Temple property, discussed by Lieberman on pages 65 and 67.
} 
The author of this midrash is well aware of the existence of qonamot ("a vow that does not involve consecration to the Lord"). However, he specifically denies that this type of vow is rooted in Scripture, ${ }^{16}$ and he insists that the prohibition in Numbers 30:3: "he shall not break his word," refers only to vows of consecration. This midrash corroborates the plain meaning of Scripture, according to which the prohibitive vow is nowhere mentioned in the Torah or the Hebrew Bible. The qonam vow, which likens an object to Temple property without actually consecrating it, is a post-biblical development, and the rabbinic interpretation of Numbers 30:3 is an attempt to invest this post-biblical institution with Torah sanction.

\section{[2] The Rabbinic Vow Formula}

If prohibitive vows are nowhere mentioned in the Hebrew Bible, when and how did they first appear? Where did the strange idea of likening an object to Temple property, without actually dedicating it, originate?

It would seem that the rabbinic notion according to which qonamot liken the banned object to Temple property is not the original explanation of the mechanism whereby these prohibitive vows take effect. As stated above, the "likening" conception is well-attested in rabbinic literature. It is explicitly mentioned in Sifre Bemidbar 153 and BT Nedarim 14a, cited above, as well as in PT Nedarim 1:4, 37a; and it is alluded to in Mishnah Nedarim 1:3-4 and Tosefta Nedarim 1:2-3. However, except for the few examples cited in these passages, vow formulae never explicitly liken the banned object to Temple property. ${ }^{17}$ The normal vow formula is not כקרבן ("[x is] like an offering"), but קרבן, and its substitute plp, which literally mean: $x$ is an offering.

And even if we were to ignore the question of explicit simile, most vow formulae cited in rabbinic literature simply cannot be explained as

\footnotetext{
${ }^{16}$ See Albeck 1959:137, note 1. Albeck claims that the following passage in Sifre Zuta explains the next words in the verse (Numbers 30:3), "imposing an obligation (לאסר אסר (ל) on himself" as referring to prohibitive vows. But this interpretation is in no way borne out by the text of Sifre Zuta itself; rather, it would seem that Sifre Zuta explains the words as referring to self-imposed obligations that do not involve ritual formulae, such as a commitment to fast. This is in fact the early rabbinic interpretation of the term issar. See Chapter 2 below, note 15. Albeck's erroneous interpretation of the Sifra Zuta on לאסר is presumably based on Maimonides' Mishneh Torah, Hilkhot Nedarim 1:1 (q.v.), which is in turn based on the use of the term issar in PT to denote a vow (see note 12 above, and below, Chapter 2, section 7).

${ }^{17}$ In Mishnah Nedarim 3:2 and Mishnah Nazir 2:1 certain corrupt witnesses read in prohibitive vow formulae, but most witnesses (including the important mss. Parma, Kaufman and Cambridge) read pרבן.
} 
likening the banned object to Temple property. At the beginning of this chapter, we cited one vow formula that does fit this bill: "qonam is $\mathrm{x}$ upon me." If qonam is taken to mean "like an offering," then the votary does indeed compare the banned object to an offering as far as he himself is concerned. However, this formula is attested in only six Mishnah passages, and twice more in the Tosefta. ${ }^{18}$ Far more common is the formula "qonam is the wine that $I^{19}$ drink," "qonam is the dish that I taste" (Mishnah Nedarim 6:1) and the like, a formula attested fifteen times in Mishnah Nedarim alone, and another ten times in Tosefta Nedarim. This formula cannot easily be explained as likening the banned object to Temple property. The votary has not tasted the dish, and he does not intend to do so. According to the "likening" conception, he wishes to render the dish off limits by comparing it to Temple property before he eats it. If his intention is to prohibit potential benefit, why does he refer to the dish "that I taste," as if he is actually tasting or intends to taste the object? Why doesn't he say: "qonam is the dish that I would have tasted," or "qonam is this dish upon me, and I shall not taste it?"

Other common vow formulae prohibit the votary from deriving benefit from any of the property of another, or prohibit another from deriving benefit from any of the property of the votary. In such cases the votary says "qonam is that which I benefit from you" (see, for example, Mishnah Nedarim 9:7), or "gonam is that which you benefit from me" (see, for example, Mishnah Nedarim 7:9). These formulae are also not easily explained according to the "likening" conception. If the intention is to compare the banned property to an offering in order to prohibit potential benefit, then the formula ought to be "qonam ('like an offering') is my property upon you" or "qonam ('like an offering') is your property upon me." It makes no sense to say "that which I benefit from you is like an offering," since there is not, and will not be, any actual benefit.

Let us reexamine these common vow formulae: "gonam is the wine that I drink" and "qonam is that which you benefit from me." According to Mishnah Nedarim 1:2, qonam is a substitute formula for qorban, "offering." These vows are thus formulated as dedicatory vows: the votary declares that certain property of his is an offering. Taken literally, these formula mean "the wine that I drink is an offering" and "that which you benefit from me is an offering," respectively. At first glance, these vows are patently absurd: if the votary drinks the wine, or if his neighbor makes use of his property, then the wine or the property can no longer be turned over to the Temple treasury. However, in point of fact,

\footnotetext{
${ }^{18}$ Mishnah Nedarim 3:2, 7:6, 11:2, 4; Nazir 2:1-2; Tosefta Nedarim 4:6, 7:3.

${ }^{19}$ Reading with Epstein 1948:496-505 and most witnesses in this and all similar formulae שאני, rather than the less clear and rather poorly-attested reading שאיני
} 
the votary has no intention of actually consecrating his property. This type of vow is a sophisticated means of creating a personal prohibition. The wine dedicated is precisely "the wine that I drink," and it thus becomes Temple property retroactively, as soon as the votary drinks it. The ownership of the digested wine, of course, cannot actually be transferred to the Temple, but the votary is retroactively guilty of trespassing with regard to Temple property. The consecration and its violation take effect simultaneously. The only practical consequence of this dedicatory vow is the creation of a personal prohibition: it is dedicatory in form, but prohibitive in effect.

The same is true of the vow prohibiting another party from deriving benefit from one's property. "That which you benefit from me is an offering" (Mishnah Nedarim 9:7) means precisely that: any property that you use of mine is dedicated to the Temple. Until such time as you use the property, it is mine, but as soon as you make use of it, it becomes Temple property. Since the consecration takes effect in tandem with its violation, I cannot actually transfer the property to the Temple, and thus the only practical effect is to prohibit you from deriving benefit from my property, for the moment you do so, you are guilty of trespassing with regard to Temple property.

As stated above, this technique can also be used to prohibit the votary himself from deriving benefit from the property of another. "That which I benefit from you is an offering" (Mishnah Nedarim 7:9) means precisely that: any property of yours of which I make use is dedicated in advance to the Temple. Although this property is not the votary's to dedicate at the time of the vow (it belongs to his neighbor), it will become his technically as soon as he derives benefit from it. Property belongs to the host until the guest derives benefits from it, at which point ownership is transferred to the guest (see Mishnah Nedarim 5:6). Therefore the potential guest can dedicate the property in advance, the dedication taking effect only when he uses the property and makes it his own. In this case, too, no actual transfer of the property to the Temple is contemplated. The consecration takes effect upon its violation, and therefore the only practical effect is to ban the votary from making use of his neighbor's property, if and when he is invited to do so. ${ }^{20}$

\footnotetext{
${ }^{20}$ In all honesty, it must be admitted that not all similar formulae can be easily explained in this sense. The vow "qonam is your house into which I enter" is cited in Mishnah Nedarim 5:3, 8:7, and Tosefta Nedarim 4:8-9; clearly the votary has no right to consecrate his neighbor's house, even if he is invited to enter therein. The same is true of the similar vow in Mishnah Nedarim 9:2, where it is clear from the context that the house is not that of the votary himself (on the other hand, in Midrash Sifre Zuta to Numbers 30:3 an earlier version of this vow is cited in the name of Hillel, and here the reference can easily be to the votary's own property).
} 
The owner of property can thus consecrate any or all of his property in the event that he himself derives benefit from it ("qonam is the wine that I drink"), or in the event that another derives benefit from it ("qonam is that which you benefit from me"). A potential guest can consecrate the property of his host in advance, in the event that he is invited to make use of the property by the host ("qonam is that which I benefit from you"). In all three cases, no actual dedication is contemplated. The vow is formulated such that the consecration takes place only upon its violation. The votary makes use of a dedicatory formula to "trap" himself or his neighbor, creating a personal prohibition subject to liability for trespass against Temple property. ${ }^{21}$

The vow formula "qonam is x upon me," found in six Mishnah passages and twice more in the Tosefta, does not quite fit this conception. According to our theory, the property is not an offering "upon" the votary specifically, but is consecrated outright. It would seem that this formula is secondary; it was derived from the formula "qonam is the $x$ that I eat." Since even according to our conception it is clear that the only practical effect of these conditional dedicatory vows that take effect upon violation is to create a personal prohibition, the formula "qonam is $x$ upon $\mathrm{me}^{\prime}$ " is used as a convenient shorthand formulation for "qonam is $\mathrm{x}$ [that I eat, and therefore it is prohibited] upon me."

According to the conception outlined here, qonamot are indeed vested with Torah sanction. A prohibitive vow is actually a dedicatory vow, and he who violates a prohibitive vow actually commits trespass with regard to Temple property. Prohibitive vows are indeed "vows to the Lord" (Numbers 30:3), even according to the plain meaning of the biblical text, since technically the banned property is consecrated, the consecration taking effect upon its violation.

\section{[3] Mark 7:11}

Vows with the formula gorban, or which otherwise make reference to consecration, are found in a number of Second Temple sources. Scholars have encountered major difficulties in their attempts to interpret these

There are other vows that cannot be explained either according to the rabbinic "likening" theory or according to the theory proposed here; for example: the vow "qonam that I shall marry (שאני נושא) so-and-so, whose father is bad" (Mishnah Nedarim 9:3). It would seem that in all of these cases the reading is preferable to the reading ש שאני in context, and these are examples of oaths misformulated with the word qonam (see the baraita at the end of BT Shevuot 20a and Tosafot ad loc.).

${ }^{21}$ See above, note 8 , and references cited there. 
vow formulae. ${ }^{22}$ On the one hand, it is clear from their contexts that these vows are not dedicatory vows in the classic sense: they create personal prohibitions, and do not involve transfer of property to the Temple treasury. On the other hand, the rabbinic conception, according to which such vows liken the banned object to an offering without actually consecrating it, does not seem to adequately explain these particular usages. Like the vast majority of rabbinic qonam formulae, these Second Temple examples are best explained as dedicatory vows which are formulated such that they create personal prohibitions, in the technique described above.

The best known of these vows dating from the Second Temple period is the vow cited in Mark 7:9-13. The context is a complaint of Jesus' against the Pharisees. The following translation is that of the New English Bible, except for the underlined words, for which see below:

(9) He also said to them, 'How well you set aside the commandment of God in order to maintain your tradition! (10) Moses said, "Honour your father and your mother," and, "The man who curses his father or mother must suffer death." (11) But you hold that if a man says to his father or mother, "Anything of mine which is used for your benefit is Corban"' (meaning, set apart for God), (12) 'he is no longer permitted to do anything for his father or mother. Thus by your own tradition, handed down among you, you make God's word null and void. And many other things that you do are just like that.'

And in the parallel passage in Matthew 15:3-6:

(3) He answered them: 'And what of you? Why do you break God's commandment in the interest of your tradition? (4) For God said, "Honour your father and mother," and, "The man who curses his father or mother must suffer death." (5) But you say, "If a man says

\footnotetext{
${ }^{22}$ Virtually all of the Second Temple prohibitive vows that have come down to us have engendered confusion among scholars: Origen designates the vow of the son in Mark 7:11 // Matthew 15:5 (for which see immediately below) "asaphesteron," or "rather obscure;" see citation in Chapter 4, section 3, below, and A. I. Baumgarten 1984-85:5-6, note 6. Even after Fitzmyer clearly described the vow inscribed on the sarcophagus from the Kidron Valley (see below, section 4, and Fitzmyer 1959:60-65) as a dedicatory vow, his view was misunderstood by Falk 1966:311-312, who thought that Fitzmyer believed that the vow was a prohibitive vow (see below, note 24). This type of vow is discussed in the Damascus Covenant (CDC) in a section entitled "On the law of votive offerings," but nonetheless Rengstorf (1965:864) writes: "...it is not clear whether p implies true transfer to the sanctuary or a plot to cheat the workers of their reward" (see below, note 55). Regarding Philo's treatment of this type of vow, A. I. Baumgarten (1984-85:8) writes: "What is unclear from our point of view is whether Philo envisions actual dedication to the Temple..., or the forbidding of objects from use as if they were korban...."
} 
to his father or mother, 'Anything of mine which is used for your benefit is set apart for God, (6) then he must not honour his father or his mother." You have made God's law null and void out of respect for your tradition.

There are two common interpretations of the son's vow. ${ }^{23}$ According to the first interpretation, the son dedicates his property to the Temple,

${ }^{23}$ There are two other interpretations of the son's vow, neither of which has gained wide support among scholars:

(1) Hart (1907:638-650) believes that in this passage Jesus is lamenting his own fate: he was a Nazirite or quasi-Nazirite, and as such all of his earnings were forfeit to the Temple, and the Pharisees forbade him to support his parents. But according to no source are the earnings of a Nazirite consecrated automatically, and the personal background envisioned by Hart is nowhere mentioned in the text.

(2) Belkin (1940:163) and Buchanan (1965:319) suggest that the formula uttered by the son is an oath "by the offering," in which the term qorban is a substitute for the divine name. Matthew 23:16-22, in which Jesus criticizes the Pharisees for legitimizing oaths by qorban, could ostensibly be cited as a prooftext for this interpretation (but see below, note 38, and section 7 of this chapter, for another interpretation of Matthew 23:16-22). However, the formula "anything of mine which is used for your benefit is qorban" simply is not an oath by qorban. The biblical oath formula would require "qorban if you make use of my property," or the like, while the rabbinic oath formula would be "qorban that you will not make use of my property." Belkin in fact suggests erasing the word ho from the son's vow, yielding the biblical-type oath formula korban ean ex emou ophelethes, "qorban if you benefit from me." But there is no evidence for this reading in any of the Greek witnesses to either Gospel. The only shred of evidence is provided by the Sinaiticus Syriac manuscript to Matthew 15:5, but even this translation follows the received reading in Mark, and it would seem that in Matthew the Syriac translator attempted to interpret the puzzling vow as a biblical-type oath. Belkin himself offers this interpretation only as a possibility; he does not rule out the possibility that the son's vow is a rabbinic-type prohibitive vow.

At any rate, the textual evidence does not justify emendation in this case. Buchanan therefore prefers to retain the received reading. In his view the Hebrew Vorlage of the Greek read קרבן שאתה נהגה לי, "qorban is that which you benefit from me," which, as we have seen, is a common rabbinic vow formula. In Buchanan's view, both the Gospels and the Rabbis misinterpreted the formula as a vow formula with some connection to dedicatory vows, while in fact the relative pronoun $-\varpi$ is an oath formula, in which the rabbinic $-v$ replaces the biblical $ם$, "if." קרבן שהת in this formula actually means "qorban if you...," not "qorban is that which you...."

But it is hardly likely that Mark, Matthew, and the Rabbis all misinterpreted this common contemporary oath formula. Moreover, according to this view, the formula is correctly understood in Matthew 23:16-22, where it is termed an oath. Why then is it mistranslated in Matthew 15:5 as korban ho ean..., "qorban is that which...?" Moreover, in rabbinic literature the laws of the $-w$ pormulae are discussed in tractate Nedarim, "vows," and not in tractate Shevuot, "oaths." The Rabbis clearly connected this formula in some fashion with dedicatory vows. It is 
thus preventing his parents from deriving benefit from it. ${ }^{24}$ According to the second interpretation, which is based upon the rabbinic understanding of the prohibitive vow, the son simply states that his property is like an offering, in that it is off-limits to his parents. ${ }^{25}$

clear, therefore, that neither the son's vow in the Gospels nor the rabbinic qonam should be interpreted as an oath.

It should be noted, however, that Lieberman (1942:129-139) considers some of the rabbinic gonam formulae rabbinic attempts to legitimize what were originally popular oaths "by the offering" (see note 38 below, and section 7 of this Chapter), but in his view there were other vow formulae in which the word qorban or qonam meant "like an offering," including the formula קונם שאתה נהנה לי

At any rate, there are compelling reasons why the formula as attested in rabbinic literature and the Gospels simply cannot be an oath formula. The particle $-\square$ is nowhere attested in the sense of "if," and this translation is etymologically unsound. Moreover, the son in Mark 7:11 cannot and does not adjure his parents not to use his possessions; they would have no reason to acquiesce and swear accordingly. He himself is said to have "sworn" that they will not use his possessions. But this is ridiculous. What has the son to gain by such an oath? He invokes a curse upon himself in the event that he provides support for his parents, and even so he has not relieved himself of the burden of their support, which is required by the Torah (see note 35 below). According to tannaitic law, the oath is not binding since it contravenes Torah law, while according to sectarian law, the oath is binding, but the swearer is forbidden to carry it out, even at the risk of a death curse (see note 36 below). In either case, there is no basis for the assumption that the Pharisees would have forbidden the son to support his parents because of this oath, a position that conforms with neither sectarian nor rabbinic halakhah, and which is illogical and unattested anywhere.

However, even if Buchanan's position is unfounded, it is clear that in the popular consciousness this type of vow was considered akin to a future-tense negative oath. See the end of this chapter.

${ }^{24}$ See, for example, Buechler 1895:83; Allen 1907:164; Gould 1896:129-130; Fitzmyer 1959:60-65; Derret 1969-70:364-368; and see also Origin's commentary to Matthew 15:1 (for citation and discussion see below, Chapter 4, section 3, and see A. I. Baumgarten 1984-85:14, and Baumgarten's note 6 on pages 5-6). Fitzmyer correctly states that after consecration the dedicated object is prohibited for common use; Falk (1966:311-312) erroneously concluded that Fitzmyer explained the son's vow as a rabbinic-type gonam. But Fitzmyer is clearly referring to the general liability for trespass with regard to Temple property. Derret distinguishes

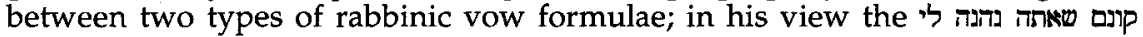
vows discussed in tractate Nedarim, banning a neighbor from deriving benefit from all of the votary's property or banning the votary from deriving benefit from all of his neighbor's property, are actually dedicatory vows in which the property is transferred to the Temple treasury, while the "qonam is the wine that I drink"-type vow likens the wine to Temple property. However, there is absolutely no basis for this distinction.

${ }^{25}$ Lightfoot 1859:226-229; Wuensche 1878:184; Wellhausen 1903:57; Mann 1917:267-268; Strack and Billerbeck 1922:711-712; Klausner 1927:306; Klostermann 1926:79; Montefiore 1968:148; Kaufmann 1929:350-352; Manson 1943:316-317; 
Both interpretations are difficult. The language of the vow does not fit either one: According to the first interpretation, the son devotes all of his property to the Temple, preempting its use by his parents. However, the vow itself, as recorded, does not devote all of the son's property to the Temple, but only that property "which is used for [his parents'] benefit." The second interpretation is also belied by the language of the vow. If the son's intention is to prevent potential benefit from his property on the part of his parents, he ought to have declared, "Anything of mine which might have been used for your benefit is [like a] Corban." And indeed, this is the translation of the New English Bible, and most modern European translations are similar. But this construction does not accurately reflect the Greek korban, ho estin doron, ho ean ex emou ophelethe(i)s, which is the construction used for a general statement (literally: "Corban, that is a gift, is whatever you enjoy of mine"). If the New English Bible translation were accurate, the Greek would have read: korban, ho estin doron, ho an ex emou ophelethes (an instead of ean, and ophelethes in the indicative, without iota subscript), which is the syntax of a conditional sentence when the condition is contrary-to-fact. A number of scholars have suggested emending the text accordingly, ${ }^{26}$ but there is no support for the emendation in any of the Greek witnesses, all of which read ean and ophelethe(i)s in both Gospels.

In addition to the fact that both of these interpretations are belied by the language of the vow, there are a number of other problems with each. The notion that the son actually consecrates his property in order to prevent his parents from deriving benefit from it is difficult for the following reasons:

(1) If the property is actually transferred to the Temple treasury, why does Jesus object to the Pharisaic position? Dedicatory vows are clearly mentioned time and again in the Torah, and they can hardly be considered rabbinic paradosis. If a man dedicates all of his property to the Temple, he clearly cannot use that property to support his parents. Even if he were to become impoverished because of reckless generosity to a

Bowman 1965:166-167; Taylor 1965:340; Falk 1966:309-312; A. I. Baumgarten 198485:13-15.

${ }^{26}$ For the emendation see Taylor 1965:341, and references cited there. The form ophelethe(i)s in the received text is the aorist subjunctive of the verb opheleo. The aorist subjunctive is not a past-tense verb, and a relative clause constructed with the word ean and a verb in the aorist tense yields a general indicative statement ("Whatever you use is qorban"). See Smith 1966:515, paragraph 2295. On the other hand, ophelethes is the aorist indicative of the same verb, which, when used with an, yields a conditional statement in which the condition is contrary-to-fact ("Were you to use my property [which you cannot do], it would be qorban"). See Smith 1966:577, paragraph 2564. 
friend, he would be unable to support his parents, and a gift to the Temple is no different. How could Jesus possibly consider this setting aside God's commandment in favor of rabbinic tradition, when both are equally God's law?27

(2) Why does the son formulate his vow as though it were directed specifically against his parents, if in fact he is devoting all of his property to the Temple? Theoretically we can explain that the son consecrated all of his assets simply in order to spite his parents. But is it conceivable that a son would so wish to harm his parents, that he would renounce all of his assets in order to prevent them from using the property? What will he himself eat from now on? One might assume that the young man will earn fresh assets after the vow takes effect. However, in such a case, he would once again be obligated to support his parents, since the new property has not been dedicated to the Temple.

It has been suggested that the son dedicates only that property set aside for his parent's sustenance. ${ }^{28}$ But if this were the case, the son would still be obligated to support his parents using other funds.

These considerations have led most New Testament scholars with even a rudimentary familiarity with rabbinic sources to interpret the son's vow as a rabbinic qonam, in accordance with the classic rabbinic interpretation of such vows. ${ }^{29}$ The son does not consecrate his property; he simply declares it off-limits to his parents "like an offering." But this interpretation is difficult as well:

(1) In both Gospels the term gorban, "offering," is translated doron (literally: "gift, offering;" New English Bible: "set apart for God"). A doron is an outright offering. It is quite clear, therefore, that the Evangelists themselves assumed that Jesus was referring to actual consecration using the gorban formula, and not to the likening of an object to an offering. Bowman suggests that just as the Rabbis used the terms qorban and qonam to mean "like a qorban," so too the Evangelists used the term doron in the sense of "like a doron."30 However, this explanation is extremely far-fetched. The Evangelists translated the Hebrew term qorban for a Greek speaking readership unfamiliar with the intricacies of Jewish law. It is hardly likely that they would have misleadingly translated qorban as doron without explaining that the actual intention is "like a doron." They could

${ }^{27}$ For this question, see Wellhausen 1903:57.

${ }^{28}$ Thus Origen (see citation and discussion below, Chapter 4, section 3), and Derret 1969-70:365.

${ }^{29}$ See above, note 25 .

${ }^{30}$ Bowman 1965:167-168. 
easily have written "korban, ho estin homoios doro(i)...," or the like; or clarified the fact that qorban is a technical term by beginning the sentence with the statement, "He who vows regarding his father and mother, "Anything of mine which is used for your benefit is qorban," in which case the Greek reader would have assumed that qorban is a technical term used in prohibitive vows, whose true significance is not really relevant. The fact that the Evangelists stressed that gorban means "offering" indicates that they believed that the vow referred to actual consecration.

(2) In Matthew 15:6-7, immediately following our passage, Jesus castigates the Pharisees as hypocrites, citing Isaiah 29:13: “...this people approach me with their mouths and honor me with their lips while their hearts are far from me, and their religion is but a precept of men, learned by rote." The same verse is cited in Mark 7:6-7, immediately preceding our passage. Isaiah accuses the people of hypocrisy: they worship God with lip service, by rote, taking seriously the outer forms of worship, but not the inner content. This citation is relevant only if we assume that the reference is to a cultic ritual; namely, a dedicatory vow that is not intended for the sake of heaven, because its sole result is to prevent one's parents from benefiting from one's property. If the vow is indeed a rabbinic-type qonam deeming the son's property off-limits to his parents like Temple property, then the purport of the vow is unabashedly to prevent the parents from benefiting from their son's property. The citation from Isaiah is completely irrelevant: on the one hand, the prohibitive vow is not, and does not claim to be, a cultic institution; on the other hand, the son is not hypocritical in the least: he is openly wicked. ${ }^{31}$

It would seem, therefore, that the son's vow in Mark and Matthew is best understood literally. The son declares that any and all of his property from which his parents derive benefit is consecrated for the Temple service. This vow cannot be fulfilled: if his parents do derive benefit from any of his property, it will be too late to transfer the property to the Temple. But in fact, the son has no intention of consecrating any property. The dedicatory vow is a clever means of denying the parents the use of any of their son's property. As soon as the parent places a morsel of food from the son's table in his mouth, the ownership of that food is transferred to the Temple treasury, and the parent is guilty of trespass against Temple property. This liability of the

\footnotetext{
${ }^{31}$ For this question, see Rengstorf 1965:866.
} 
parents is the only actual consequence of the vow. The son does not dedicate all of his property to the Temple; he dedicates only that property from which his parents will derive benefit. At no stage is he required to actually transfer property to the Temple, since the consecration takes effect simultaneously with its violation, at which point it is too late to actually give the property to the Temple.

This elegant turn of phrase enables the son to bar his parents from using his property. He does so by making cynical use of the biblical dedicatory vow. Jesus' criticism must be seen in this light: The son is making use of a cultic form, the dedicatory vow, in order to bypass the fifth commandment, "Honor thy father and mother." But it would seem that Jesus would have objected to the use of this type of vow even if it were directed at someone other than the votary's parents, as is evident from the citation of Isaiah 29:13. The use of a dedicatory vow formula for personal ends is hypocrisy and lip service. The votary makes an outward consecration of property, without any intention of actually donating the property to the Temple.

It is clear from Jesus' criticism that he viewed this as a case in which rabbinic legislation conflicts with Torah law. In his view, if a dedicatory vow is formulated in such a way that the property will never actually be transferred to the Temple, it does not take effect, even if it is technically flawless. The fact that the Rabbis differed with Jesus and gave sanction to these prohibitive vows is an example of the way in which they preferred their paradosis over the Torah commandment to honor one's parents. The Pharisees, however, presumably viewed this type of vow (which is technically a flawless dedicatory vow) as binding according to Torah law, and even if they had been inclined to agree with Jesus that this type of vow is hypocritical, they would not have considered themselves authorized to declare such vows null and void.

It would seem, however, that the Rabbis looked with favor upon the use of dedicatory vows to create personal prohibitions (except, of course, in cases like the one described in the Gospels, in which a son bars his parents from his property). As stated above, this type of a vow can serve as an oath substitute. The violation of an oath was considered especially sinful, because of the dire warning in the third commandment: "for the Lord will not clear one who swears falsely by his name (literally: takes his name in vain)" (Exodus 20:7). The people therefore tended to avoid oaths, and the Rabbis encouraged the use of certain substitutes instead of direct oaths in God's name. ${ }^{32}$ A dedicatory vow that results in a personal prohibition can serve as a substitute for a future-tense negative oath. Unlike the violation of an oath, for which, according to the Decalogue,

${ }^{32}$ See Lieberman 1942:125-141. 
there can be no acquittal, ${ }^{33}$ unintentional trespass against Temple property can be atoned for with relative ease. Even intentional trespass is, according to one view, a simple negative commandment punishable by flogging. According to a second tannaitic view, intentional trespass is punishable by death, ${ }^{34}$ but even according to this opinion, violation of a vow does not have the same emotional and religious significance as taking the name of the Lord in vain.

It is important to note, however, that in the case under discussion in the Gospels the vow is not used as an oath substitute. The assumption of the Gospels is that the son is obligated to support his parents by virtue of the fifth commandment. ${ }^{35}$ The son cannot absolve himself of this obligation. An oath "I swear that I will not support my parents" is an oath in contravention of Torah law, and according to tannaitic halakhah such oaths do not take effect. Even if we were to assume that this tannaitic halakhah was not prevalent during Jesus' time, ${ }^{36}$ the son's oath not to support his parents would still not relieve him of the burden of supporting his parents. If the parents were to sue for the son's support, he would be obligated to support them in violation of his oath, calling down upon his own head the curse implied in the oath. The vow, on the other hand, places the ball in the parents' court. The son can continue to fulfill his obligation by inviting his parents to his home and even serving them food, but it is they who are forbidden to eat the food by dint of the trespass liability that hangs over their head. And if one were to point out

${ }^{33}$ It should be noted, however, that the Rabbis reinterpreted Exodus 20:7 in a way that does not preclude expiation (see Mekhilta Bahodesh 7; PT Shevuot 3:11, 34a; BT Temurah 3b; BT Shevuot 21a). Pre-talmudic halakhah, however, was extremely stringent with regard to oaths (see Belkin 1940:144-156 and references cited there), and even in talmudic times, perjury was considered a very serious offense. ${ }^{34}$ See above, note 8 .

${ }^{35}$ In accordance with the position of Huna b. Hiyyah in PT Qiddushin 1:7, 61a, and R. Judah in BT Qiddushin 32b. I assume that this view was considered authoritative in Jesus' time, and the Pharisees did not dispute this basic premise. ${ }^{36}$ See CDC XVI, 8-9: "Anything that a person obligates himself to do in violation of the Torah, he shall not carry out even at the cost of death." The oath is binding, but it is forbidden to fulfill it, even at the risk of the death invoked in the oath curse (see above, note 23). Belkin 1940:147-148 concludes on the basis of this passage that perjury is punishable by death according to CDC. But all the text is really saying is that the curse invoked in the oath may place the violator at the risk of death. Schiffman (1991:202-203) claims that no death sanction at all is implied here. He believes that according to CDC, as in rabbinic halakhah (Mishnah Shevuot 3:6), an oath contradicting Torah law does not take effect, and therefore the violation of such an oath is inconsequential. According to Schiffman, the phrase "even at the cost of death" is simply an expression meaning that under no circumstances should the swearer fulfill his vow. I see no evidence whatsoever for this interpretation. 
to the son that he is not living up to his moral obligation toward his parents, he could cynically reply that he has dedicated the food that they eat to the Temple, and honoring God is more important to him than honoring his parents.

The son's use of the vow formula is not in the least bit innocent. It is not motivated by the fear of God and the wish to avoid taking the Lord's name in vain, but rather by a wish to bar his parents from using his property. The Pharisees certainly would not have encouraged the use of vows under such circumstances. They were very concerned with parental respect, and tannaitic halakhah explicitly allows for the abrogation of vows out of respect for one's parents. ${ }^{37}$ However, if the son is indeed intent upon barring his parents from his property, he will hardly seek to abrogate his vow, and thus the rabbinic dispensation is useless in this case. And, despite the rabbinic concern with the issue of respect for parents, the Pharisees did not consider it possible to prohibit the use of a prohibitive vow in this particular case. The formula used by the son is an actual dedicatory formula, and as such, it takes effect according to Torah law. The Pharisees had no problem with this type of vow, and once they sanctioned it, they were powerless to distinguish

\footnotetext{
${ }^{37}$ Mishnah Nedarim 9:1 (see also Mishnah Nedarim 3:2). Those who interpret the son's vow as consecration or qonam have a hard time explaining the difference between Jesus' point-of-view and that of the Rabbis, since both believe that the vow can and should be annulled in order to allow the son to honor his parents. Some scholars have therefore argued that the institution of absolution of vows in rabbinic halakhah, or at least the loophole allowing annulment out of respect for one's parents, postdates Jesus. See inter alia Epstein 1957:377; A. I. Baumgarten 1984-85:15-17; and Baer 1966:120, note 8. This may well be the case (see discussion below, Chapter 6), but according to our interpretation of Jesus' criticism, it is irrelevant. Jesus objects to the very institution of prohibitive vows, which in his view makes a mockery of the consecration formula. In his view vows that do not result in the actual donation of property are simply invalid.

S. Abramson, cited in Baer 1966:120-121, likewise argues that the issue of absolution of vows is irrelevant. Following Kaufmann (1929:350-352), Abramson argues that the son's vow is a classic rabbinic-type qonam, likening his property to an offering vis-a-vis his parents, and Jesus objects to the rabbinic view that qonamot (as opposed to oaths) apply even when they violate Torah law (Mishnah Nedarim 2:2). The fact that the vow could be absolved at the request of the son is irrelevant, since until that point the vow is in effect. There is a problem, however, with Abramson's claim. In Mark 7:12 it is stated specifically that according to the Pharisees "he is no longer permitted to do anything for his father or mother," implying that he now wishes to support his parents, and seeks absolution of his vow, but the Pharisees will not permit it. According to our interpretation, however, Jesus objects to all prohibitive vows, and his choice of an extreme example which is morally reprehensible and contrary to Torah law is merely a rhetorical device.
} 
between moral and immoral uses. The vow takes effect once uttered, whether the Pharisees approve or not.

Even if we are correct in assuming that the Pharisees, like Jesus, would have found the son's use of the prohibitive vow reprehensible, it is clear that there is nonetheless a major difference of opinion between Jesus and the Pharisees regarding the prohibitive vow per se. In Jesus' view, dedicatory vows that cannot be fulfilled are a sacrilege. Their validation by the Rabbis is an example of rabbinic paradosis that is reprehensible in its own right, ${ }^{38}$ and certainly in cases where the vow is

${ }^{38}$ Jesus' objection to the use of dedicatory vows in order to create personal prohibitions is reflected in Matthew 23:16-22 as well:

(16) Alas for you, blind guides! You say, "If a man swears by the sanctuary, that is nothing; but if he swears by the gold of the sanctuary, he is bound by his oath." (17) Blind fools! Which is the more important, the gold, or the sanctuary which sanctifies the gold? (18) Or you say, "If a man swears by the altar, that is nothing; but if he swears by the offering that lies on the altar, he is bound by his oath." (19) What blindness! Which is more important, the offering, or the altar which sanctifies it? (20) To swear by the altar, then, is to swear both by the altar and by whatever lies upon it; (21) to swear by the sanctuary is to swear both by the sanctuary and by him who dwells there; (22) and to swear by heaven is to swear both by the throne of God and by him who sits upon it.

Lieberman (1942:134) explains that the Rabbis did not accept the use of concrete nouns as substitutes for the divine name in oath formulae (see Mishnah Shevuot $4: 13)$, and therefore they did not recognize oaths by the sanctuary or the altar. On the other hand, they legitimized what were originally oaths by the offering that lies upon the altar and the gold of the sanctuary by reinterpreting them as qonamot, prohibitive vows, in which the banned object is likened to an offering or Temple property.

Why does Jesus object to this distinction? Is he unaware of the difference between oaths and vows? From the formulation of the vow in Mark 7:11 // Matthew 15:5 it is clear that Jesus (or the author of the report in the Gospels) understood full-well that an "oath" by an offering is not an oath at all, but a vow formula declaring the property "qorban." It would seem therefore that Jesus did know the difference between an oath and a vow, but the vow to which he refers is not the likening of an object to Temple property, but an actual dedicatory vow that is phrased such that it cannot be fulfilled. Jesus objected vehemently to this profane usage of the institution of consecration. However, it was difficult to convey this opposition to the public, on whom the technical distinction between oaths and vows was, to a large extent, lost (see the end of this chapter). Therefore Jesus employs rhetorical devices in order to express his opposition to the Pharisaic legitimization of prohibitive vows. In Mark 7:9-13 and Matthew 15:3-9, Jesus cites an extreme example in which a prohibitive vow is used to circumvent Torah law and common decency, while in Matthew 23:16-22 Jesus compares the prohibitive vow to an oath, mocking the rabbinic hairsplitting that distinguishes one type from the other. In both cases he uses rhetorical devices to express his 
designed to contravene a Torah obligation. The Pharisees, by contrast, viewed these vows as real dedicatory vows that are binding according to Torah law, even if no actual donation of property ensues. The use of the dedicatory vow for personal ends is not a sacrilege in their view, since the votary clearly states the circumstances under which his vow will take effect, and does not disguise the fact that no actual donation is contemplated. As we have surmised above, it is likely that the Rabbis encouraged the use of this type of vow as an oath substitute. In the example cited by Jesus, the vow is misused in a case where an oath would not have been effective. The Rabbis no doubt considered this abuse reprehensible, but they considered themselves powerless to prevent it.

\section{[4] The Kidron Valley Sarcophagus Inscription}

A vow similar to that of the son in Mark 7:11 is attested in an Aramaic inscription on a sarcophagus discovered in the Kidron Valley (Jebel hallat at-Turi), ${ }^{39}$ which reads as follows:

כל די אנש מתהנה בחלתה דה קרבן אלה מן דבגוה

Anything that anyone uses in this sarcophagus is a qorban to God from him who is in it.

Milik defined the term qorban here in the sense of curse, and theorized that the inscription is a curse designed to ward off grave robbers. ${ }^{40} \mathrm{He}$ suggests that the text of the inscription is corrupt, and the word די דיuld be omitted, yielding:

כל אנש מתהנה בחלתה רה קרבן אלה מן דבגוה

Anyone who uses this sarcophagus is [liable to] a qorban/curse of God from him who is in it.

However, even though some scholars argue that qorban occasionally served as an oath formula, at least in popular usage, ${ }^{41}$ the word qorban is never attested in the sense of curse, nor is there any reasonable etymology that would allow for such a meaning. Moreover, the reading posited here requires emendation, and the syntagma כל מתהנה ב-, as found in the emended text, is unusual, to say the least.

deeply felt opposition to any use of the prohibitive vow. The opposition itself is based upon Jesus' sense that the use of a dedicatory vow formula when no actual donation ensues is a sacrilege.

${ }^{39}$ For a description of the find, see Fitzmyer 1959:60.

${ }^{40}$ Cited by Fitzmyer 1959:60-61. See reference there.

${ }^{41}$ See above, notes 23 and 38 , and the end of this chapter. 
Fitzmyer explains that the inscription is an actual dedicatory vow: ${ }^{42}$ the grave goods ${ }^{43}$ are offerings to God, and therefore they are off-limits for personal use. However, the concept of burial offerings is unquestionably alien to Judaism, and they are nowhere mentioned in Jewish literature. Burial objects discovered in Jewish graves of the Second Temple period were not offerings to God. They were most probably personal effects buried with the deceased, either to honor him or to serve him in the world-to-come. Offerings to God are donated only to the Temple treasury, and if the deceased did in fact intend to consecrate his possessions as posthumous offerings, he ought to have seen to it that they were transferred to the Temple treasury, rather than having them buried along with his remains. According to Fitzmyer's view, the deceased himself is guilty of trespass with respect to Temple property!44

Other scholars interpret the inscription as a rabbinic-type prohibitive vow directed against potential grave robbers. ${ }^{45}$ However, the phrase

${ }^{42}$ Fitzmyer 1959:62-63.

${ }^{43}$ According to A. I. Baumgarten (1984-85:7), the inscription warns against making use of the sarcophagus itself (and perhaps the bones in the sarcophagus as well; see note 18 there, and note 45 below). But it seems more reasonable to translate the בחלתה of the usual sense, "in the sarcophagus," as referring to the grave goods, as all other scholars who discussed this inscription interpreted it. See also the interesting interpretation of Qimron 1994:271, who interprets as אל, yielding an inscription banning the use of the grave goods by anyone other than the deceased himself: "Anything from which anyone other than he who is inside it derives benefit in this grave is qorban."

${ }^{44}$ Fitzmyer actually refers to the vow as "a vestigal survival of much older mortuary offerings." But since he goes on to state that the vow reserves the grave goods for sacred use, it is unclear how this vow differs from an actual mortuary offering. It would seem that in his view the vow at this later stage was intended only to deter grave robbers, and not to honor God.

For grave goods in ancient Israel, see Stern (1976:16-23). For the possibility that the goods were intended for the use of the deceased in the world-to-come, compare the custom of מבחי מתים, food offered to the deceased. These offerings were customary in pre-exilic and post-exilic Israel (Deuteronomy 26:14, Tobit 4:17, and Ecclesiasticus 30:18, which opposes the custom). If according to this conception the deceased is in need of sustenance, it follows that he was thought to need other personal effects as well. In BT Berakhot $18 \mathrm{~b}$, a ghost asks that certain personal effects be sent to her by means of another woman who was to be buried the next day.

The notion that the goods were buried out of respect for the deceased can be compared with a similar tannaitic custom, which according to the Rabbis is rooted in pre-exilic practice: the burning of the clothes and personal effects of the deceased, in order to prevent others from using them. See BT Avodah Zarah 11a; PT Sanhedrin 2:8, 20c.

${ }^{45}$ Falk 1966:311-312; A. I. Baumgarten 1984-85:7; Greenfield 1976:59-60. See also above notes 22 and 44, for Fitzmyer's position. Greenfield defines this vow as a 
קרבן אלה מן דבגוה ,an offering to God from him who is in it" makes little sense according to this view. According to the rabbinic conception, prohibitive vows liken the banned objects to Temple offerings. The word qorban in rabbinic vows simply means "like an offering." The banned property is not necessarily compared to an offering from the votary himself, but to Temple property in general. Just as Temple offerings in general are off-limits for common use, so the property mentioned in the vow is off-limits to the person mentioned in the vow. If this had been the intention in the Kidron Valley inscription, the vow would not have specified that the contents of the sarcophagus are an offering to God from the deceased buried within. Why specify the recipient of the offering (אלה) and the donor (Dן דבגוה), ${ }^{46}$ when no actual offering is being described, and the intent is simply to liken the contents of the grave to Temple property in general?

The vow in this inscription is identical in form to the vow in Mark $7: 11$, and it would seem that it, too, should be taken literally. The vow is a real dedicatory vow to God from the one buried within (קרבן אלה מן דבגוה). But the deceased did not consecrate the contents of the grave in toto, but only those contents that will be used by potential grave robbers (כל די אנש מתהנה בחלתה דה), so that these grave robbers will be guilty of trespass against Temple property if and when they make use of the contents of the grave. Until the grave is robbed, its contents are not consecrated, and therefore there is no reason to give the property to the Temple. The consecration takes effect only upon its violation by the grave robbers. ${ }^{47}$

qonam, but he does not specifically say that in his view rabbinic qonamot operate through the mechanism of likening the objects banned to Temple property. He compares the term qonam to the Phoenician word מp, which he interprets as an oath formula (see the Chapter 4, section 2, below), and it may be that he considered the sarcophagus formula an oath.

${ }^{46}$ A. I. Baumgarten 1984-85:7, note 18, cites an oral suggestion of Greenfield's according to which בחלתה דה stands in apposition to מן רבור , and the vow means: "Any benefit that a person derives from this sarcophagus, from he that is in it, is gorban to God." According to this explanation, the vow is directed against the use of the bones of the deceased themselves. But this interpretation is not convincing. ${ }^{47} \mathrm{Like}$ the vow of the son in the Gospels, this vow, too, is not an oath substitute. The deceased cannot adjure potential grave robbers not to rob his grave, nor can he himself swear, before his death, that his grave will not be robbed, since the fulfillment of this oath is not under his control. According to later rabbinic halakhah, future-tense oaths concerning the actions of others, over which the swearer has no control, are not binding (see PT Shevuot 3:5, 34c; BT Shevuot 25a), and even if we were to assume that this restriction postdates the Second Temple period, it would be absurd for the deceased to have invoked a curse upon himself before his death in the event that his grave is robbed. This does not deter potential grave robbers, and the curse would take effect only after the swearer's 


\section{[5] The Consecration of Food in the Damascus Document}

The Gospels and the sarcophagus inscription from the Kidron Valley date from the first century C.E. But the use of dedicatory vows to create personal prohibition is attested as early as the first century B.C.E. ${ }^{48}$ In the Damascus Document (CDC), XVI, lines 13-15, in the context of the laws of votive offerings, we read: ${ }^{49}$

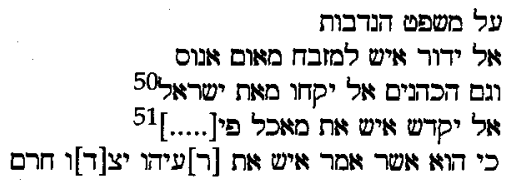

On the law of votive offerings:

Let no man vow for the altar anything taken by force.

Also the priests shall not take from an Israelite.

Let no man consecrate the food of [his] mouth [to Go]d,

death, at which point it would be meaningless. The prohibitive vow in this case is not an oath substitute. It is designed to implicate potential grave robbers in an additional sin, that of trespass against Temple property, if and when they decide to violate his grave. Even grave robbers who would otherwise justify their actions by saying that they are unlikely to get caught, and that they are only robbing from a dead man who does not know the difference, would likely be deterred by the sanction against trespass with regard to Temple property (pace Derret 1969-70:367). This vow is thus similar to the vow of the son in the Gospels, but unlike that vow, this one is not morally reprehensible.

${ }^{48}$ Some of the fragments of CDC found in Qumran date from the Hasmonean period. See J. M. Baumgarten, in Broshi 1992:57.

${ }^{49}$ The passage has been preserved in fragment 4QDf from Qumran and in the Geniza manuscript T-S $10 \mathrm{~K} 6$, first published by Schechter (for our passage, see Schechter 1970:103). Qimron has recently published a facsimile of the Qumran text with a transcription in which lacunae are reconstructed on the basis of the Geniza manuscript (in Broshi 1992; for our passage see Broshi 1992:40-41). In our passage their are no variants, even in orthography, between the Geniza text and that of $4 \mathrm{QDf}$, and the two texts taken together enable us to reconstruct a substantial portion of the text. The transcription which follows is based on the two texts; letters enclosed in brackets are illegible or missing in both texts.

${ }^{50}$ There is a lacuna in the Geniza fragment following the word מרו", which in the past had led scholars to assume that a word meaning "by force" (such as בחז (אנוס) is missing, since the priests are, of course, entitled and obligated to take offerings from an Israelite under other circumstances (see Schechter 1970:88; Rost 1933:28; Rabin 1958:77). But it is clear from the Qumran fragment that no word is missing, and the lacuna in the Geniza fragment was originally a space between laws, preceding the word $\$$, which belongs to the next law. Nonetheless, it is clear from context that the verb "P", "take," is used here in the specialized sense of "take by force." Compare I Samuel 2:12-17 (the description of the sins of the sons of Eli), in which the verb לקח, "take," is used in this sense a number of times. 51Rabin 1958:77 and Qimron in Broshi 1992:41 reconstruct: אל יקדש איש את מאכל פי[הו לא]ל For other reconstructions, see note 55 below. 
for that is what it says (Micah 7:2): "And each hunts his neighbor (MT: brother) ${ }^{52}$ with a net (also: a ban)."

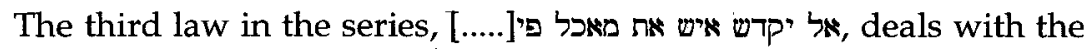
consecration of the food of one's mouth. It is clear from context ("the law of votive offerings"), that the reference is to actual consecration, and not to mere prohibition or ban..$^{53}$ If the reference is to actual consecration, then it is impossible to explain that the Damascus document prohibits the consecration of potential foodstuffs, i.e. food or money set aside for personal consumption, since all Temple offerings are offerings of potential foodstuffs. The only way this law can be understood is literally, in the manner that we interpreted the vows in Mark 7:11 and the Kidron Valley inscription: the reference is to a person who consecrated the food

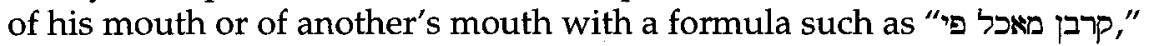

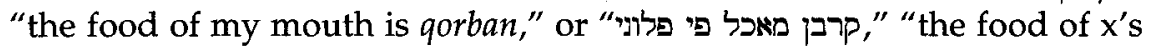
mouth is qorban." This vow does not involve the actual donation of property to the Temple, since the property donated is מאכל פה, property that is actually eaten by himself or another. Once the food is eaten, it can no longer be given to the Temple. The only practical consequence of the vow is to create a personal prohibition, the consequence of which is liability for trespass against Temple property, as in the vows in the Gospels and the Kidron Valley inscription.

The translation of the line from CDC is based upon the reconstruction אל יקדש איש את מאכל פי[הו ל] אל , which seems most likely. ${ }^{54}$ According to this translation, the law deals specifically with a votary who consecrates the food of his own mouth, creating a self-imposed prohibition. Presumably such vows were limited in time; the votary said: , "the food of my mouth today is qorban," or the like, in which case the vow is tantamount to a self-imposed fast for a limited period. Although the fast itself is an act of religious devotion with which $\mathrm{CDC}$ would have no quarrel, the scroll forbids the use of dedicatory vows for any purpose other than actually transferring property to the Temple treasury. Fasting is noble its own right, but it is forbidden to impose a fast by means of a dedicatory vow, when the votary has no intention of giving anything to the Temple, since this is an outward ritual form with no content, or lip service to God.

${ }^{52}$ The Vorlage $r$ "yhw, "neighbor," is reflected in LXX as well. Some scholars suggested reconstructing " $b d w$, "his servant," instead of $r^{\prime} y h w$ (see note 55 below), but this reading is impossible according to either manuscript fragment.

${ }^{53}$ But see the citation from Rengstorf 1965:864, in note 22 above.

${ }^{54}$ See above, note 51. The words $ל[. . .[$ מאכל פי are found only in the Geniza fragment; they are missing entirely from 4QDf because of a lacuna. In the Geniza fragment part of the letter following $פ$ is visible, and it looks like the letter $\pi$ or a similar letter. 
$\mathrm{CDC}$ forbids the use of this type of vow even where there is no moral problem, as in the case of fasting. However, the placement of the law in the scroll shows that the author of the scroll was well aware of the fact that this type of vow could be abused in morally reprehensible cases such as the one described in the Gospels. The laws immediately preceding the law under discussion prohibit the consecration of property taken from another by force, and the forceful appropriation of "offerings" from the people on the part of the priests (cf. I Samuel 2:1217). Then comes our law, "Let no man consecrate the food of his mouth to God," followed by a prooftext, "And each hunts his neighbor (so also LXX, MT: brother) with a herem" (Micah 7:2). There follow a number of further laws directed against the abuse of consecration. Since the prooftext from Micah follows upon our law immediately, it would seem that the author of CDC was well aware that the consecration of foodstuffs could be used to "hunt" one's neighbor, preventing someone who is dependent upon the votary (such as a parent or an employee) from deriving benefit from his property. ${ }^{55}$ Thus both the Gospels and $\mathrm{CDC}$ object to the use of dedicatory vows in order to create a personal

${ }^{55}$ In view of the prooftext Micah 7:2, perhaps it would be preferable to explain that the pronoun 1 - in the word refers back to the ישראו "Also the priests shall not take from an Israelite; let no man consecrate the food of his [=an Israelite's] mouth to God." Perhaps we should even reconstruct

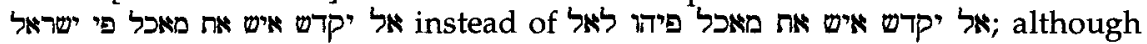

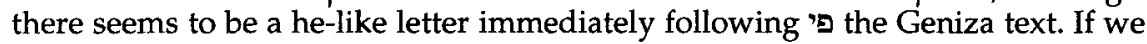
take פיהו as referring back to the Israelite of the previous law, or if we reconstruct פי ישראל, the reference would be to an Israelite dependent upon the votary for support, as in the son's vow vis-a-vis his parents in the Gospels.

A number of scholars have suggested that in view of the prooftext Micah 7:2, the text should be reconstructed so that it refers explicitly to a vow used to cheat others of their due. Rengstorf (1965:864) reconstructs as follows, on the basis of various suggestions cited by Rost (1933:28) in his critical apparatus: (ואל יקדש איש את מאכל פעלו כי הוא אשר אמר איש את עבדו יצודו חרם declare holy the sustenance of his worker, for this is what (Scripture) says (cf. Mi. 7:2): This one and that takes his servant with herem." According to this reconstruction, the reference is to an employer who owes his employee wages or sustenance. He pays them their due, but as he does so he declares "the food of my employee is qorban." Rengstorf (and presumably the scholars who first suggested this reconstruction) explains that the food consecrated was food intended as sustenance or wages for the employee, but in that case the employer would by law be required to give the employee other food or wages. According to our interpretation of the vow, the consecrated food would be the actual food given the employee, which becomes sacred as soon as the employee eats it. At any rate, a cursory look at the witnesses reveals that this reconstruction is untenable: the letter ' in the word פיהו is not missing in the Geniza fragment, and

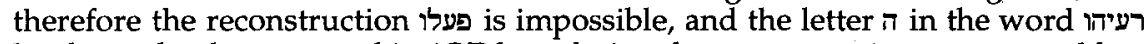
has been clearly preserved in 4QDf, rendering the reconstruction עבדו untenable. 
prohibition for two reasons: (1) it makes a mockery of the institution of consecration, since the votary has no intention of actually dedicating any property, and (2) it can easily be abused as a means of denying a dependent his due.

The Pharisaic halakhah undoubtedly objected to the abuse of this type of vow, but the Pharisees nonetheless viewed it as a valid dedicatory vow, which creates liability for trespass against Temple property. Jesus does not consider such vows valid at all, since the consecrated object is defined as something that the votary himself or another will eat or use, and thus nothing is actually dedicated. Jesus considered the validation of this type of vow a hypocritical rabbinic tradition rather than a Torah law, which the Rabbis had to accept.

Morally, the sectarian view of this type of vow outlined in CDC is identical to that of the Gospels. The scroll therefore prohibits the use of such vows for any purpose whatsoever. However, since the scroll refers to such vows in the context of the laws of votive offerings, it would seem that CDC agrees with the Pharisees that these vows are technically valid according to Torah law, and must be honored once vowed. Nonetheless, it is forbidden to vow such vows, since they make a mockery of consecration and are open to abuse.

\section{[6] The Vow in Philo's Hypothetica}

Philo of Alexandria, writing at the beginning of the common era, deals with prohibitive vows in the context of his treatment of dedicatory vows in his book Hypothetica. Only two fragments of this work have been preserved, since they are cited in Eusebius' Praeparatio Evangelica. The work is an apology for Judaism. In the first fragment, Philo surveys a number of Jewish laws, including the laws of dedicatory vows, and in the second he describes the lifestyle of the Essenes. The following is a translation of the discussion of vows (Praeparatio Evanglica VIII, 7.3-7.5). The translation is that of F. H. Colson in the Loeb Classical Library edition of Philo, volume 9, pp. 424ff., except for the italicized words, for which see below:

7.3 ...Each individual is master of his possessions unless he has solemnly named the name God over them or declared that he has given them to God. And if he has merely made a chance verbal promise of them he must not touch or handle them, but hold himself at once debarred from them all.

7.4 I need not consider the case of his robbing what belongs to the gods or plundering what others have dedicated; even with his own, I repeat, a chance word of dedication spoken unawares deprives him of them all and if he repents or denies his promise his life is forfeit also. 
7.5 The same holds of any other persons over whom he has authority. If a man has devoted his wife's sustenance to a sacred purpose [lit. : "named a sacred name over his wife's sustenance"] he must refrain from giving her that sustenance; 56 so with a father's gifts to his son or a ruler's to his subjects....

Baumgarten is uncertain whether this passage treats dedicatory or prohibitive vows. ${ }^{57}$ It is clear, however, that the phenomenon described in 7.5 is identical to that which lies behind the son's vow in Mark 7:11 and the "hunting of the neighbor" in CDC. It is possible to shirk one's responsibility toward one's dependents ("any other persons under his authority") by consecrating the food that they eat. He need not actually give any property to the Temple, and he can actually claim to be supporting his dependents, for it is they who are forbidden to eat the food, which becomes sacred as soon as it is eaten. Surprisingly, Philo is not in the least bit critical of this type of vow; on the contrary, his intention is to describe with pride the scrupulous conduct of the Jews with respect to vows.

It would seem that "naming the name of God" over property, as described in paragraphs 7.3-7.4, also refers to this type of prohibitive vow. In 7.3 Philo describes two cases in which a person is debarred from his possessions: if he has "solemnly named the name of God over them," or if he has "given them to God." Colson thinks that the second modifies the first, and he therefore translates "unless he has solemnly named the name of God over them declaring [emphasis mine] that he has given them

\footnotetext{
${ }^{56}$ Greek: trophes anekhein; literally: "to refrain from the sustenance." In an appendix, Colson (1941:539) cites Edersheim (1873:367), who claims that according to the Mishnah, a man could not vow what of his fortune he owed to others nor his widow's portion. Colson wonders why Philo allows and seemingly approves such wicked behavior. In the wake of this comment, Rokeah, in his Hebrew translation of the Hypothetica (in Daniel-Nataf 1986:160), translates "he is banned from her sustenance." But this interpretation is far more problematic, since the husband is prohibited from eating his wife's sustenance or widow's portion even without a vow. Moreover, if the reference is to a dedicatory vow, the wife is banned from the sustenance as well, as are all commoners.

It is clear that Colson's translation is correct. Edersheim's representation of the mishnaic view is absolutely wrong. According to Mishnah Ketubot 7:1, a man can deny his wife her sustenance by means of a gonam, which takes effect, although if he persists in this behavior, he is required to divorce her. This vow is analogous to that of the son in the Gospels, and is clearly the type of vow that Philo envisions here. Moreover, according to Mishnah Arakhin 6:2, if a man vows mortgaged property or his wife's widow's portion to the Temple, the vow takes effect (although a technical resolution of the plight of the wife and the creditor is suggested, which see).

${ }^{57}$ See citation above, note 22 .
} 
to God." 58 But the Greek me theon ge epiphemisanta autois med' hos to(i) theo(i) tauta aniesin refers specifically to two different actions: one can either dedicate property to God outright, ${ }^{59}$ or one can name the name of God upon the property without actually donating it to the Temple. Philo goes on to explain that "a chance verbal promise" debars the owner from the property. It would seem that this line refers specifically to one who named the name of God upon an object without actually donating it, for if the reference were to actual consecration, Philo would simply have said that the votary must transfer the property to the Temple as soon as possible, taking care to avoid touching it in the meantime. And in light of the law regarding "naming a sacred name" over the sustenance of one's wife, it would seem that in 7.3 as well, "naming the name of God over" one's possessions refers to the consecration of the votary's own sustenance, the equivalent of CDC's "consecrating the food of one's mouth." The votary formulates his vow such that the object of the vow is precisely that property of which he will make use ("qorban is the food of my mouth," "qorban is the wine that I drink"). That is why in paragraph 7.4 Philo makes much of the fact that this case differs from the usual trespass against Temple property. Even if the property trespassed against has not actually been transferred to the Temple treasury, "a chance verbal promise" can engender liability for trespass.

Philo, too, was thus familiar with the use of dedicatory vows in order to create personal prohibitions. He terms this type of vow "naming the name of God" over a possession. The votary can bar himself from his own property by means of this technique (incurring obligatory selfdenial as an act of religious devotion), and he can also avail himself of this technique in order to bar his dependents from his property.

\section{[7] The Prohibitive Vow in Tannaitic Literature}

The four Second Temple sources concur in their evidence that it was customary to make use of dedicatory vows in order to create a personal prohibition. All of the sources refer directly or indirectly to the use of such vows in order to bar others from using one's property: in the Gospels the son uses this technique to deny his parents their due; in the Kidron Valley inscription the deceased uses this technique to deter grave robbers; CDC alludes to the fact that the consecration of foodstuffs could be used to entrap one's fellow man; and Philo writes that a householder could consecrate the food of his dependents. It is thus clear that one primary use of this type of vow during the Second Temple period was to

\footnotetext{
58 See Colson 1941:425; Rokeah, in Daniel-Nataf 1986:160, note 11.

${ }^{59}$ The verb aniemi can mean either "let loose" or "consecrate." See Liddel and Scott, s.v.
} 
make others liable for trespass, and in some cases this technique was used vis-a-vis others in order to deny them their due. It may be, therefore, that the technique of using dedicatory vows in order to create personal prohibitions was originally designed as a means of oppressing others. But it seems more likely that this type of vow was originally. developed as an oath substitute, which does not involve the potential abuse of God's name: the votary who consecrates the food of his mouth, in the words of CDC, or solemnly names the name of God upon one or other of his possessions, in the words of Philo, bars himself from using a certain possession or eating certain food. This is a personal commitment akin to a negative future-tense oath. However, since technically one can just as well bar others from making use of one's property by means of the same technique, the technique was applied to others soon after its inception, and banning others from using one's property by means of a vow was used by the unscrupulous as a means of denying dependents their due.

The passages from the Gospels make it clear that the Pharisees considered this type of vow valid, even when used unscrupulously. The Pharisaic position is based upon three elements:

1. Technically, this type of vow is a valid dedicatory vow according to Torah law, and the Rabbis were powerless to declare it invalid.

2. In contrast to the sectarian position and that of Jesus, the Pharisees saw nothing wrong with dedicating property to God that by definition cannot actually be turned over to the Temple treasury. The votary is in no way cheating the Temple treasury, since it is clear from the start that his intention is merely to create a personal prohibition, and not to donate property to the Temple.

3. The Pharisees discouraged the taking of oaths in God's name. This type of vow is a convenient substitute.

This type of vow thus became a legitimate institution in Pharisaic halakhah, despite the vehement opposition of the sectarians and Jesus. The rabbinic qonam is undoubtedly rooted in this type of vow. Nonetheless, the rabbinic sources that have come down to us seem byand-large unaware of the fact that the gonam is a type of dedicatory vow. In rabbinic literature as we know it, prohibitive vows are clearly distinguished from dedicatory vows, and are considered a different phenomenon altogether. Dedicatory vows are discussed in a number of tractates in the order Kodashim: Arakhin, Temurah, and Me ilah, while qonamot are dealt with in tractate Nedarim of the order Nashim. As stated above, the dominant view among Tannaim and Amoraim is that qonam formulae are not actual formulae of consecration, but rather 
formulae that liken specific objects to Temple offerings vis-a-vis the votary himself or someone else mentioned in the vow. ${ }^{60}$ Similarly, the votary can liken all of his property to an offering vis-a-vis someone else, or liken all of someone else's property to an offering vis-a-vis himself.

But, as we have seen, the most common rabbinic vow formulae belie this explanation of the vow phenomenon and reveal the true meaning of the prohibitive vow. The specific vow "the $\mathrm{x}$ that I eat is qorban/qonam," and the general vows "that which you use of mine is qorban/qonam" and "that which I use of yours is qorban/qonam" indicate that the prohibitive vow prevalent in rabbinic times is none other than the vow that we encountered in the Gospels, the Kidron Valley inscription, CDC, and Philo; it is a dedicatory vow that cannot be fulfilled, because by definition it takes effect only upon its violation. ${ }^{61}$

Some of the tannaim, however, were well-aware of the true origin and meaning of the prohibitive vow. Rabbi Meir and Rabbi Simeon differ in Tosefta Nedarim 2:962 as to whether one who violates a gonam incurs liability for trespass against Temple property. Rabbi Simeon's view is that he does not, since a vow is only a likening of an object to a Temple offering, not an actual act of consecration. Rabbi Meir, on the other hand, believes that liability for trespass against Temple property is incurred, presumably because it is a real act of consecration, which takes effect upon its violation.

Rabbi Simeon's view is cited in the parallel passages in BT and PT Nedarim ${ }^{63}$ in the name of "the Sages," and presumably his view was the dominant one at the end of the tannaitic period. The notion that gonamot liken the banned object to consecrated property without actually consecrating it finds expression in Mishnah Nedarim 1:3-4, according to which כאימר ("like a [sacrificial] sheep"), כקרבן ("like an offering"), and other similar formulae are effective vow formulae. ${ }^{64}$ According to the interpretation of these Mishnah passages in PT, these formulae are in fact

\footnotetext{
${ }^{60}$ See references above, note 11 .

${ }^{61}$ Moreover, two Mishnah passages in tractate Nedarim, Mishnah Nedarim 3:5 and Mishnah Nedarim 4:2 (presumably early passages stemming from Temple times or shortly thereafter), clearly indicate that prohibitive vows were originally considered dedicatory vows even in rabbinic literature. See Benovitz 1995:224225. See also Mishnah Nedarim 5:6, and the discussion in Benovitz 1995:225, note 73.

${ }^{62}$ See also parallels in PT Nedarim 4:2, 38c; PT Ketubot 13:2, 35d; BT Nedarim 35a; BT Shevuot 22a-b. And see Lieberman 1967:430-432.

${ }^{63}$ See references in the previous note.

${ }^{64}$ See also parallel passages in Tosefta Nedarim 1:2-3. Both the Mishnah and Tosefta passages are difficult to understand, and they seem to contradict each other in a number of places; for a cursory survey of the problems, see Benovitz 1995:226, notes 76-77.
} 
the ideal, and the Sages and Rabbi Judah differ as to whether qorban (normally considered the classic vow formula) is a valid formula at all (PT Nedarim 1:4, 37a):

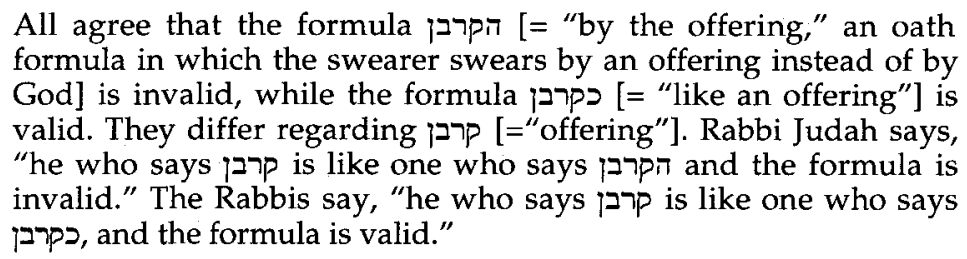

It would seem therefore that by the end of the tannaitic period most Rabbis explained qonamot as likening the banned object to an offering, and not as an actual consecration formula. Rabbi Meir in Tosefta Nedarim 2:9 preserved the original conception of the prohibitive vow, reflected in Second Temple sources, but his colleagues differed with him and interpreted the classic formula qorban and its substitute gonam in the sense of כקרכן, "like an offering." This interpretation is reflected in Sifre Bemidbar 153 to Numbers 30:3, in Mishnah Nedarim 1:3-4, in BT Nedarim 14a, and in PT Nedarim 1:4 (37a).

This new rabbinic conception most likely originated shortly after the destruction of the Temple. Even before the destruction of the Temple, the populace did not clearly understand the technique that lay behind the prohibitive vow formula. Qorban was considered a promissory formula akin to an oath, which results in a personal prohibition. The exact meaning (consecration that takes effect upon violation) was lost on most people, as is evident from the following sources:

1. In Matthew 23:16-22, Jesus mocks the Pharisees who legitimize the oath formulae "qorban" and "the gold of the Temple," while invalidating oaths by the altar or the Temple itself. The reference is clearly to the distinction the Pharisees made between the valid prohibitive vow formulae "the food that I eat is qorban" and "the gold that I use is dedicated to the Temple," on the one hand, which are valid consecration formulae that take effect upon violation, and the oath formulae "I swear by the altar" or "I swear by the Temple," on the other hand, which are invalid because the swearer uses the terms altar and Temple as substitutes for the divine name. Jesus was no doubt aware of the distinction, as his sophisticated claim concerning the son's vow in Mark 7:11 makes clear. Nonetheless, he mocks the rabbinic distinction by terming the prohibitive vow an 
oath "by qorban." 65 This mocking rhetoric can be effective only if the audience is unaware of the true nature of the qorban vow.

2. Josephus, ${ }^{66}$ writing shortly after the destruction of the Temple, cites a Greek philosopher by the name of Theophrastus, ${ }^{67}$ who mentions a Jewish oath formula qorban which has no parallel in other tongues, the use of which was prohibited in Tyre. Lieberman's view, ${ }^{68}$ that the reference is to an oath using the word qorban as a substitute for the divine name, is problematic. Lieberman himself provides ample documentation of the fact that the gentiles swore by all that is holy and profane, ${ }^{69}$ and even if he is correct in interpreting certain sources in rabbinic literature as indicating that Jews, too, swore by their Temple sacrifices, ${ }^{70}$ the qorban oath would hardly qualify as a uniquely Jewish phenomenon unparalleled in other tongues. On the other hand, prohibitive vows using the word qorban, i.e. dedicatory vows that create personal prohibitions and serve as oath substitutes, are most certainly a uniquely Jewish phenomenon. It would seem that Josephus was referring to this phenomenon, ${ }^{71}$ but he nonetheless terms the qorban formula horkos, "oath," rather than euche, "vow." This shows that in the popular consciousness prohibitive vows were considered more like oaths than dedicatory vows. When the theoretical basis of the prohibitive vow is unclear, it makes little sense to term the qorban vow "euche," a Greek word that refers specifically to dedicatory vows and the accompanying prayers. It is more like a horkos, or "oath."

3. In the passage cited above from Philo's Hypothetica, he does not refer to the vow as a horkos or euche. But elsewhere he uses the terms interchangeably to describe future-tense oaths, ${ }^{72}$ demonstrating that the cultic nature of the vow was unclear to him.

\footnotetext{
${ }^{65}$ See above, note 37.

${ }^{66}$ Josephus, Contra Apion, I, 167. See citation and discussion in Stern 1974:12-13.

${ }^{67}$ A pupil of Aristotle. See Stern 1974:8-9. If Josephus is correct in his citation of Theophrastus, then the practice of using dedicatory vows to create personal prohibitions, which is otherwise first attested in the first century B.C.E., can actually be dated as early as the third century B.C.E.!

${ }^{68}$ Lieberman 1942:130.

${ }^{69}$ Lieberman 1942:117-141.

${ }^{70}$ But see discussion below, Chapter 5 , sections 5 and 6 .

${ }^{71}$ See also Halevy (1906:314) and Belkin (1940:158-159), who offer a similar interpretation, except that they envision a classic rabbinic qonam likening an object to Temple property.

72 See, for example, Philo, De Specialibus Legibus, II, 12-13. And see Belkin 1940:156-158.
} 
Thus even during Second Temple times, the popular consciousness viewed the prohibitive vow as a ban formula akin to an oath, and not necessarily as an act of consecration that cannot be fulfilled. It is only natural, therefore, that after the destruction of the Temple people continued to use formulae such as "the food of my mouth is qorban," or "this wine that I drink is qorban," even though offerings to the Temple treasury were no longer possible. But after the destruction of the Temple these vows lost their halakhic sanction, since the violator of such vows could no longer be considered liable for trespass against Temple property. The consequence of violation was theoretical only, and certainly was no longer a real deterrent. The Rabbis therefore revalidated the prohibitive vow formula by reinterpreting the word qorban and its substitute qonam: these were no longer seen as actual consecration formulae, but rather as shorthand for כקרב, "like an offering." In order to anchor this new votive institution in Torah law, the Rabbis reinterpreted Numbers 30: the "vow to the Lord" referred to in this chapter is not the dedicatory vow familiar from the rest of the Torah, but rather a different type of vow, likening an object to Temple offerings and thus placing it under a ban. The Rabbis felt that this reinterpretation of the vow of Numbers 30 was legitimate, since the prohibitive vow as they understood it is akin to the "oath obligating self-denial" discussed in the same chapter.

But, as we have seen, traces of the original meaning of the prohibitive vow have been preserved throughout rabbinic literature: the most common vow formulae in rabbinic texts give evidence of the true meaning of the prohibitive vow. Sifre Zuta, a halakhic Midrash known to preserve early, non-mainstream halakhic positions, interprets Numbers 30 as referring to dedicatory vows, which would indicate that prohibitive vows, to the extent that they are binding, are actual dedicatory vows that cannot take effect unless they are violated. A number of other passages in rabbinic literature also reflect this more ancient conception, most notably Rabbi Meir's position rendering non-fulfillment of a vow liable for the penalty incurred for trespass against Temple property. 


\section{2}

\section{ISSAR: A Term in Search of Meaning}

\section{[1] Five Meanings of the Term Issar}

As we have seen in the previous chapter, the first of the votive institutions mentioned in the Kol Nidre prayer, neder, is treated extensively in biblical, Second Temple, and talmudic literature. The second votive institution mentioned in Kol Nidre, issar, is far less wellknown. Although mentioned repeatedly in Numbers 30, the term is not found elsewhere in the Hebrew Bible. ${ }^{1}$ Because the biblical usage is so limited, the precise meaning of the term was never quite clear, and it took on different connotations over time.

No fewer than five distinct meanings of the term issar can be clearly differentiated. Three of these are attested as actual usages: the term issar was used in three different senses during the biblical, tannaitic, and late amoraic periods, respectively. The issar of Numbers 30 is a future-tense oath; the term is either used alone in the sense of oath of obligation, or in conjunction with shevu'ah, the more common word for oath, in order to indicate that the shevu ah referred to is a future-tense oath of obligation. During the first three centuries of the common era, the term was used in Palestine to denote a resolution to fast $t^{2}$ for a single day. In late third- and fourth-century Palestine the term was used as a synonym for vow, and issar was often used as a substitute vow formula instead of the mishnaic term qonam. ${ }^{3}$

\footnotetext{
${ }^{1}$ An Aramaic cognate occurs a number of times in Daniel 6, in the sense of "edict."

${ }^{2}$ Or abstain from certain foods. Abstention from meat and wine often took the place of a complete fast as a sign of mourning or penitence. See Daniel 10:3, Testament of Reuben 1:10 (where this type of abstinence is actually termed "fasting"), Testament of Judah 15:4, IV Esdras 9:24, and Cowley papyrus no. 30. See also G. F. Moore 1927:257.
}

${ }^{3}$ See below, Chapter 4 . 
Two further definitions are also attested, but these are in all likelihood merely theoretical, and do not reflect actual usage. These definitions are cited in the name of the Babylonian amoraim Abaye and Rava respectively in BT Shevuot 20a. Abaye believed that the biblical issar was a secondary oath linked to an already existing oath, in which the swearer "likens" his status vis-a-vis a certain item to his status vis-avis an item previously forsworn. ${ }^{4}$ Rava, on the other hand, defined the biblical issar as a commitment formula using the word issar, which could be either an oath or a vow, depending upon how it is phrased. It is clear that Abaye and Rava were not referring to institutions with which they themselves were familiar; ${ }^{5}$ they were merely attempting to define the elusive term issar as it appears in Numbers 30 and in rabbinic literature.

\section{[2] Issar in Numbers 30}

Numbers 30, which the Rabbis term פרשת נדרים, "the vow passage," actually treats both vows and oaths. As we have seen in the previous chapter, the mainstream position in rabbinic literature is that the vows treated in this chapter are not the dedicatory vows mentioned elsewhere in the Hebrew Bible, but prohibitive vows likening an object to Temple property vis-a-vis the votary himself or another individual. ${ }^{6}$ The rabbinic interpretation was shown in the previous chapter to be a secondary development; the biblical text itself actually refers to "vows to the Lord," in the usual sense of donations to the Temple. ${ }^{7}$

One reason the Rabbis may have allowed themselves the liberty to claim that the vow of Numbers 30 is a prohibitive vow is that throughout Numbers 30 the word neder, "vow," is mentioned in tandem with the words shevu ah, "oath," or issar, "obligation," or some combination thereof:

(3) If a man vows a vow to the Lord, or takes an oath imposing an obligation (השבע שבועה לאסר אסר) upon himself, he shall not break his

\footnotetext{
${ }^{4}$ See below, section 6 of this chapter. This notion is patterned on the rabbinic conception of the prohibitive vow, according to which a prohibitive vow likens the banned object to property already vowed to the Temple. See above, Chapter 1.

${ }^{5}$ The concept of likening one oath to another makes little sense, and is unattested in rabbinic literature except in Abaye's interpretation. Issar is nowhere attested as a votive formula in its own right in texts that predate Rava. This usage is found only in Palestinian literature of the generations following Rava, as a result of Rava's interpretation, which was brought to Palestine by his colleague, Rabbi Yirmiyah. See below, section 7 .

${ }^{6}$ See above, Chapter 1 , section 1 .

${ }^{7}$ See above, Chapter 1, section 1, and the citation from Sifre Zuta in section 3 of this chapter.
} 
word; he must carry out all that has crossed his lips. (4) If a woman vows a vow to the Lord and imposes an obligation (וזר while whe still in her father's household by reason of her youth... (5) all her vows shall stand and every self-imposed obligation (וכל אסר אשר אסרה על נפשה) shall stand. (6) But if her father restrains her on the day he finds out, none of her vows or self-imposed obligations (אסריה אשר אסרה על נפשה) shall stand... (7) If she should marry while her vow or the commitment to which she has obligated herself (מבטא שפתיה אשר אסרה על נפשה) is still in force, (8) and her husband learns of it and offers no objection..., her vows shall stand and her self-imposed obligations (ואסריה אשר אסרה על נפשה) shall stand. (9) But if her husband restrains her... he thereby annuls her vow which was in force or the commitment to which she obligated herself (ואת מבטא שפתיה אשר אסרה על נפשה)...(10) The vow of a widow or of a divorced woman, however, whatever she has imposed upon herself (כל השר אסרה על נפשה) shall stand. (11) So, too, if, while in her husband's household, she vows a vow or imposes an obligation upon herself by oath (אסרה אסר על נפשה בשבועה) (12) and her husband learns of it, yet offers no objection - thus failing to restrain her - all her vows shall stand and all her self-imposed obligations (וכל אסר אמר אסרה על נפשה) shall stand. (13) But if her husband does annul them on the day he finds out, then nothing that has crossed her lips shall stand, whether vows or self-imposed obligations (ולאסר נפשה)... (14) Every vow and every oath obligating self-denial may be upheld by her husband or annulled by her husband. (15) If her husband offers no objection from that day to the next, he has upheld all the vows or obligations (או את כל אסריה) she has assumed; he has upheld them by offering no objections on the day he found out.

As the following table indicates, in nearly all of the verses cited, two distinct institutions are clearly mentioned, the first of which is always a vow:

$\begin{array}{ll}\text { v. 3: vow or } & \text { oath imposing obligation } \\ \text { v. 4: vow and } & \text { obligation } \\ \text { v. 5: vow and } & \text { obligation } \\ \text { v. 6: vow and } & \text { obligation } \\ \text { v. 7: vow or } & \text { commitment...obligated } \\ \text { v. 8: vow and } & \text { obligation } \\ \text { v. 9: vow and } & \text { commitment...obligated } \\ \text { v. 10: vow which she has imposed (lit.: } & \text { obligated) } \\ \text { v. 11: vow or } & \text { obligation } \\ \text { v. 12: vow and } & \text { obligation } \\ \text { v. 13: vow and } & \text { obligation } \\ \text { v. 14: vow and } & \text { oath obligating self-denial } \\ \text { v. 15: vow or } & \text { obligation }\end{array}$

In the majority of verses, the vow is mentioned alongside the "obligation" (issar). The vow is mentioned alongside the "oath imposing obligation" (שבועה לאסר אסר) in verses 3 and 11; in verses 7 and 9 the vow 
is mentioned along with the "commitment obligating oneself" (מבטא שפתים אשר אסרה על נפשה); and in verse 14 the vow is mentioned alongside the "oaths obligating self-denial." It is clear from the context that all of the verses are dealing with the same pair of institutions: the terms issar, "obligation," and מבטא שפתים, "commitment" (literally: "utterance of the lips"), are synonyms for shevu ah, "oath."

These two institutions, the dedicatory vow and the oath of obligation, are not identical, or even similar, in function. What they have in common is not the fact that both are means of imposing personal prohibitions, as the Rabbis believed, but rather the fact that both are means of taking upon oneself religious obligations beyond those mandated by the Torah: a vow is a self-imposed obligation to make an offering to the Temple, while an oath obligating self-denial is a selfimposed restriction undertaken as an act of worship, such as a fast. The passage as a whole warns men to take these acts of personal devotion seriously, while at the same time giving men authority to overrule their wives and daughters when they undertake such devotions. The man of the house is thus responsible for the religious life of his household: it is up to him to decide when and how God will be worshipped by himself, his wives, and his daughters.

The word issar, "obligation," whether used alone or in construct with the word shevi ah, plays an important role in the passage. It is not a mere

${ }^{8}$ Verse 4 , in which the woman is said to "vow a vow and impose an obligation," may perhaps have led the Rabbis to believe that a vow is a commitment tantamount to other self-imposed obligations, and not a separate category (see Chapter 1, above). The same conclusion can be adduced from verse 10, in which only the vow is mentioned as an institution, and that very institution is referred to with the verb "obligate," implying that a vow is a subcategory of issar, obligation. However, verse 5 makes it clear that the particle - in verse 4 is to be understood in the sense of "or," not "and," and that two distinct institutions are referred to in verse 4: vows and obligations. And although as far as verse 10 is concerned no such counterproof can be cited, verse 10 is the only one in the entire chapter in which vows are mentioned alone, without a second category of oath or obligation. Instead, the verse speaks of vows to which the widow or divorcee obligates herself, whereas elsewhere in the chapter the verb "vow" governs the noun "vow." This would indicate that the text should be emended to yield (or understood as shorthand for) "the vow of a widow or divorced woman, and whatever she has imposed upon herself (וכל אשר אסרה על נפשד), shall stand."

In verse 14, which in Hebrew reads literally "Every vow and every oath of obligation to afflict the soul," the modifying phrase "to afflict the soul" can be understood to refer back to "vow" as well. This, too, may have led the Rabbis to believe that the passage as a whole treats vows and oaths which impose personal prohibitions. However, there is no need to interpret the verse in this way, and it is far more likely that "to afflict the soul" modifies "oath of obligation" only, yielding the above translation: "Every vow and every oath obligating self denial." 
synonym for shevi ah; it is necessary in order to clarify the fact that the "oath" treated in Numbers 30 is a future-tense oath of obligation, and not a past-tense asseverative oath. Issar is thus shorthand for shevu'at issar, oath of obligation, a phrase which is meant to distinguish the oaths of this chapter from past-tense oaths, which are discussed in the Decalogue (Exodus 20:7) and Leviticus 19:12. Likewise, the phrase מבפא שפתים in verses 7 and 9 (literally: utterence of the lips), which we have translated commitment, is used in place of the word shevu ah because it refers specifically to future-tense oaths, as is clear from Leviticus 5:4: "Or when a person swears to commit himself to good or evil לבפא בשפתים להרע או להטיב), literally: "to utter with his lips to do good or evil").

We have translated the word issar "obligation." 9 According to this translation, the word technically can refer to either positive or negative future-tense oaths. Only in Numbers 30:14 are the oaths said to obligate specifically "self-denial," in which case they are unquestionably religious in nature and negative in form. Does the passage give the husband and father authority over all oaths of commitment, even those that do not involve self-denial and are not meant as acts of devotion? Presumably the answer is yes, but since women were not usually thought to be involved in commerce or other public affairs that would involve "secular" oaths, the primary reference is to oaths of religious obligation. And since positive acts of worship come under the rubric of vows, the oaths referred to in the chapter are primarily "oaths obligating selfdenial," namely fasts and other forms of abstinence undertaken as acts of worship.

Some, however, translate the word issar "prohibition," 10 in accordance with the meaning of the similar term in rabbinic Hebrew. ${ }^{11}$ The verb Binding can be used as a metaphor for any type of obligation. However, in rabbinic Hebrew, the metaphor was taken literally, and hence a person "bound" (אסור) was thought to be prohibited from doing something, while a person "released" (מותר) was thought to be permitted to do something. Eventually, the terms מותר ane came to be applied to the prohibited or permitted acts themselves, although the metaphor is really not apt in that case. ${ }^{12}$ At any rate, in biblical Hebrew the term issar probably refers

\footnotetext{
${ }^{9}$ Following Weinfeld 1975:123.

${ }^{10}$ See Milgrom 1990:251.

${ }^{11}$ During the late amoraic period issar became a synonym for prohibitive vow in Palestine, at least in part because of the connotation of the rabbinic word See below, section 7 .

${ }^{12}$ See Breuer 1987:132-134.
} 
to all kinds of future-tense oaths, whether positive or negative, to which the swearer binds himself.

\section{[3] The "Commemorative Days" Baraita}

The tannaitic Midrash Sifre Bemidbar, paragraph 153, interprets the terms issar and mivta' as synonyms of the word shevu 'ah, "oath," in accordance with the plain meaning of Scripture. In the comment on Numbers 30:4, Sifre Bemidbar states: "issar is none other than an oath;" in the commentary to Numbers 30:7 in the same paragraph, Sifre Bemidbar interprets the term מבטא, which we have translated "commitment," in the exact same way. Elsewhere in the same passage in Sifre Bemidbar various laws concerning oaths are derived from the modifying phrase לאסור אסר על נפשו, "imposing an obligation upon himself" (Numbers 30:3), such as the fact that an oath (as opposed to a vow) cannot be taken with regard to the actions of others, or to violate Torah law.

This type of exegesis is typical of the school of Rabbi Ishmael, to which Sifre Bemidbar is usually ascribed. According to this school, "the Torah spoke in human language," and therefore elegant variation and modification are legitimate means of expression, even if somewhat redundant or pointless from the point-of-view of content. ${ }^{13}$ However, the rival (and more influential) school of Rabbi Akiba, to an offshoot of which $^{14}$ a second tannaitic Midrash on Numbers, Sifre Zuta, is usually ascribed, believed that every variation in terminology and every modifier that is not strictly necessary from the point-of-view of content has specific legal significance. Sifre Zuta, therefore, considers the issar a third institution, identical with neither the shevu ah ("oath") nor the neder ("vow"). Thus Sifre Zuta to Numbers 30:3:

"If a man vows a $v o w$ " - Does this perhaps refer both to a vow that involves consecration to the Lord and to a vow that does not involve consecration to the Lord? Scripture teaches:

"to the Lord" - a vow that involves consecration to the Lord.

If he violates [the prohibition in this verse] by [breaking] vows, how do we know [that he violates it] also by [breaking] oaths? Scripture teaches: "or takes an oath."...

If he violates [the law] by [breaking] vows and oaths, how do we know [that he violates it] also with by [breaking] others? Scripture teaches: "imposing an obligation" (לאר ראר (לא).

\footnotetext{
${ }^{13}$ See Epstein 1957:521-536 (especially 522).
}

14 See Epstein 1957:741; Lieberman 1968. 
Sifre Zuta thus interprets Numbers 30:3 as referring to vows, oaths, and "other" commitment formulae. Albeck takes the term "others" at the end of this passage to refer to vows other than vows of consecration. ${ }^{15}$ But this interpretation is impossible, since the beginning of the midrash specifically rules out the possibility that our passage is dealing with nondedicatory vows. It is clear from the structure of the passage that the word "others" cannot refer to any type of vow: vows that do not involve consecration are ruled out in the first paragraph; oaths and vows of consecration are dealt with immediately prior to the discussion of "others." The word "others" must refer to commitment formulae other than oaths and vows. ${ }^{16}$ The prohibition against violating such promises is derived from the words לאסר זסר , "imposing an obligation."

What are these "other" commitment formulae? There are no clues in the Bible, because the Bible itself, as we have seen, uses the term issar as a synonym or modifier of shevu'ah, "oath." We must turn to rabbinic literature for elucidation of the interpretation of issar found in Sifre Zuta.

Which rabbinic texts use the term issar to denote commitment formulae other than oaths or vows? Two baraitot purport to define the term issar. Both are cited in the sugyot in BT and PT with bearing on this issue: BT Shevuot 20a-b and PT Nedarim 1:1 (36c-d). One of the baraitot has been preserved in Tosefta Nedarim 1:4 as well. Let us begin our discussion by citing this baraita, which we shall henceforth refer to as the "commemorative days" baraita, as it appears in the Tosefta:

What is the issar referred to in the Torah?

He who says: "It is incumbent upon me not to eat meat and not to drink wine, like the day (כיום) that I saw Jerusalem destroyed, or like the day (וכיום) that so-and-so was killed, he is bound [by his word].

The baraita as cited is difficult to understand. The basic premise of the baraita, that an issar is a commitment formula likening meat and wine to "the day I saw Jerusalem destroyed" or some other commemorative day, is clearly based upon the rabbinic interpretation of the qonam as "likening," which we discussed in the previous chapter. Apparently, we are to assume that the person making the issar had been prohibited by vow or oath from eating on the commemorative day in question, and he now likens a new oath or prohibitive vow to his former one. However,

\footnotetext{
${ }^{15}$ Albeck 1959:137, note 1 . See above, Chapter 1, note 16.

${ }^{16}$ The midrash gradually adds to the list of votive institutions discussed in Numbers 30:3. It begins by asserting that only dedicatory vows are included in the prohibition against breaking one's word; it then adds oaths as well; and finally it asserts that even "other" commitment formulae are included. If Albeck were correct, the literary structure of the midrash would be incomprehensible (dedicatory vows, not prohibitive; oaths, too; prohibitive vows, too).
} 
this important information is not explicitly stated in the baraita. ${ }^{17}$ Moreover, it is not clear what the function of the issar is, according to this baraita. Why would anyone liken a new undertaking to a previous one, rather than simply vowing or swearing anew not to eat meat and drink wine?

The versions of the baraita in BT and PT, although slightly different, ${ }^{18}$ do not seem to preserve more original readings or readings that resolve any of the questions raised above. The reading of the Tosefta translated above is found in the three main witnesses to the Tosefta: the Vienna and Erfurt manuscripts, and the printed edition, with only minor differences. One difference is worthy of note: the Vienna manuscript has "like the day (כיום) that I saw Jerusalem destroyed, or on the day (וביום) that so-andso was killed." The reading וביום is corroborated by a Geniza fragment. In

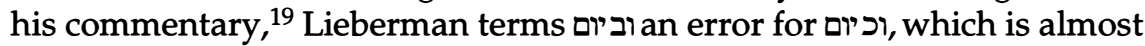
the same graphically. Indeed, $ב$ and $\supset$ are indistinguishable in some hands, and, since the Vienna manuscript has כיום ב כhe first time, it would seem that the issue should end there. Nonetheless, Lieberman is careful to note that the reading is corroborated not only by the Geniza fragment, but also by a geonic citation of the baraita. ${ }^{20}$ In Rabbi Hefetz's Book of Precepts, an Arabic halakhic work of the tenth century, our baraita is cited in Hebrew with ביום both times:

What is an issar? On the day (ביום) that the Temple was destroyed, on the day (ביום) that Rabbi so-and-so died, it is incumbent upon me not to eat meat and not to drink wine. ${ }^{21}$

According to this reading, "the day the Temple was destroyed" 22 and "the day Rabbi so-and-so died" are clearly the anniversaries of the days in

${ }^{17}$ It is stated in an amoraic gloss on the baraita cited in PT Nedarim 1:1, 36c, and BT Shevuot 20a. See citations below, at the end of this section. However, as we shall see below, this amoraic gloss originally meant something entirely different, and it has been reinterpreted by the editors of the talmudic sugyot.

${ }^{18}$ See citations below, at the end of this section.

${ }^{19}$ Lieberman 1967:403.

${ }^{20}$ Lieberman 1967:403, note 37; and 404.

${ }^{21}$ See the edition of Halper 1915:182.

${ }^{22}$ All other versions of the baraita (Tosefta Nedarim 1:4, PT Nedarim 1:1, 36c, and BT Shevuot 20a) have "the day that I saw Jerusalem destroyed." Hefetz's reading is difficult, since the fast of the Ninth of $\mathrm{Ab}$ commemorating the destruction of the Temple is considered obligatory even without a resolution to fast; moreover, one must abstain from all food and drink, and not only meat and wine.

It would seem that the vow was "updated" in Hefetz's Book of Precepts. The original baraita as cited in the Tosefta, presumably formulated shortly after the destruction of Jerusalem in 70 C.E., referred to "the day that I saw Jerusalem destroyed," and "the day so-and-so was killed" (presumably during the war that preceded the destruction of Jerusalem). The dates were changed in the Geonic 
question. The issar is simply a resolution to abstain from meat and wine as an act of mourning on the anniversary of a death. This reading is far preferable to the other, since it does not involve recourse to the strange concept of "likening" one oath to another. It provides us with the key to understanding not only the baraita itself, but the nature of the issar according to Sifre Zuta. The "other" commitment formulae referred to in Sifra Zuta, which are neither oaths nor vows, are commitments with no formula at all: "It is incumbent upon me not to ... on such-and-such a day." The word shevu ah, with its presumed curses, is not used here, nor is the word qorban or qonam, with its ensuing trespass sanction. ${ }^{23}$

Sifre Zuta and this baraita interpret the word issar in light of the rabbinic usage of the term in the sense of prohibition. According to these tannaitic sources, an issar is simply a self-imposed prohibition, which takes effect despite the fact that it lacks the formalistic trappings of an oath or prohibitive vow.

It would seem that the issar institution as reflected in the "commemorative days" baraita and in Sifre Zuta undermines the very notion of a commitment formula. If, indeed, Numbers 30:3 requires that one keep an informal promise to fast called an issar, under penalty of law, what additional significance does a formal oath or vow have?

In our view, an amoraic statement which follows immediately upon the citation of the "commemorative days" baraita in both PT and BT originally addressed this very issue. However, because the redactors of both PT and BT read ביום in the baraita instead of were forced to reinterpret the amoraic statement as well. The following is a translation of the "commemorative days" baraita and the ensuing amoraic comment as it appears in BT Shevuot 20a:

work to "the day the Temple was destroyed" and "the day Rabbi so-and-so died," since hundreds of years later one can hardly be expected to have witnessed the destruction. The fast of the Ninth of $\mathrm{Ab}$ must have slipped the mind of the tradent or scribe responsible for updating the baraita, who was concerned only with making the dates relevant to his contemporaries.

BT raises a similar problem vis-a-vis the mention of the anniversary of Gedaliah's death in its version of the baraita (see citation below, at the end of this section), since it assumes that the fast of Gedaliah, on the anniversary of Gedaliah's death, is obligatory. See Shevuot 20b, and Tosafot ad loc., s.v. דכי לא נדר. It would seem, however, that the tradent responsible for BT's version of the baraita did not view the fast of Gedaliah as obligatory or even as a widespread custom.

${ }^{23}$ Even according to the dominant rabbinic conception, which views the qonam vow as mere "likening" to Temple property, in which case no trespass sanction follows (see Chapter 1, section 1), the very likening to Temple property is what makes the vow effective and brings it under the rubric of Numbers 30:3. If Numbers 30:3 prohibits breaking one's word even without likening a banned object to Temple property, what is the point of this "likening?" 
What is the issar referred to in the Torah?

He who says: "It is incumbent upon me not to eat meat and not to drink wine, like the day (כיום) that my father died, like the day that so-and-so died, like the day Gedaliah son of Ahikam was killed, like the day that I saw Jerusalem destroyed, he is bound [by his word].

And Samuel said: providing that he had been bound by vow since that day (מאותז היום).

Samuel's statement is not cited here in its original form. In a parallel passage in BT Nedarim 12a the same baraita is cited, and Samuel comments "providing he vowed on that day (באותו היום). It is the Talmud in Nedarim that emends Samuel's statement to read "since that day" (מאותו היום) because of the exigencies of the passage in Nedarim, which are not relevant to our issue. ${ }^{24}$ The reading באותו is corroborated by the parallel passage in PT Nedarim 1:1, 36c, which cites a slightly different form of the baraita:

What is an issar? This loaf is to me like the day (כיום) that father died, like the day so-and-so was killed, like the day that I saw Jerusalem destroyed. That is the issar referred to in the Torah.

Rabbi Ba in the name of Rabbi Yohanan and Rav; both say: This is only if he took a vow on that day (באותו היום).

The statement cited in the name of Samuel in BT is thus brought by Rabbi Ba in the name of Rabbi Yohanan and Rav in PT. Since in the version of the baraita cited in both Talmudim the issar is an oath ${ }^{25}$ or vow likening a new undertaking to a former one, the amoraic statement has always been taken to mean that the issar is valid only if the votary was initially bound by a vow to abstain on the day that he saw Jerusalem destroyed, or so-and-so killed. In the context of the redacted talmudic passages, that is indeed the meaning. However, as we have seen, the correct reading in the baraita is ביום ather "It is incumbent upon me not to eat meat or drink wine on the day that I saw Jerualem destroyed, or on the day that so-and-so was killed." If we assume that Samuel and/or the amoraim cited in PT were familiar with the original

${ }^{24}$ See BT Nedarim 12a; Benovitz 1993:625-626, note 27.

${ }^{25}$ According to BT, the issar described in the "commemorative days" baraita is a vow; in fact, it is more like an oath (see Tosafot Shevuot 20a, s.v. שלא אוכל). BT asserts (in a line from BT Shevuot 20a not quoted here) that Abaye interpreted the baraita as referring to a vow, and then applied the principle of likening to oaths as well (מדמתפיס בנדר נדר, מתביס בשבועה שבועה). Despite this assertion, it is clear that Abaye understood the likening in the baraita as the likening of one oath to another, and this baraita is in fact the source of his "likening" concept as applied to oaths. See below, section 6. If this is the case, then Abaye no doubt thought that Samuel was using the term "vowed" loosely, in the sense of "swore." 
ביום version of the baraita, the amoraic statement takes on an entirely different meaning: because the issar commitment does not make use of formalistic language, and is linguistically indistinguishible from any offhand promise, it is binding only if uttered on the day of the fast/abstinence. The issar thus compensates for its lack of formality with its immediacy: it is binding because it is uttered immediately prior to the onset of the fast.

This amoraic statement does not reflect the plain meaning of the baraita. If the votary says "on the day my father died," he clearly is not uttering the issar on the day in question, but long beforehand; most likely, he declares on the actual day of his father's death that he will abstain from meat and wine each year on the anniversary of the death. However, the amoraim were disturbed by the fact that this issar is considered binding even though it does not make use of the formal language of an oath or vow; they therefore insisted that the issar is binding only if uttered (or reiterated) immediately prior to the fast.

\section{[4] Issar in the Scroll of Fasting}

The term issar is also used in the sense of an undertaking to fast in what is often considered the earliest extant rabbinic text, the Megillat Ta anit, or Scroll of Fasting. ${ }^{26}$ The title of the scroll is misleading: it is actually a list of minor festivals on which fasting is prohibited. The text dates to the end of the Second Temple period. ${ }^{27}$ It is thus earlier than our baraita, which clearly assumes that Jerusalem is destroyed.

The Scroll of Fasting opens with the statement: "These are the days on which one may not mourn and on which one may not fast." The list of days follows, after which the scroll concludes with the statement: "except a person who has previously undertaken 28 an issar $\left(70 / 70^{29}\right)$ in prayer;" in other words, no one may fast on these days except someone

\footnotetext{
${ }^{26}$ See Lichtenstein 1931-32:257-351, for an edition of the Scroll.

27 Lichtenstein 1931-32:257-258.

${ }^{28}$ Hebrew דאטיתי עלוהי מן קדמת דנו, lit. "who there is upon him from beforehand." The word for "there is" is "אית. Some witnesses have " instead of "א. $\$$ " and "are interchangeable in Palestinian Jewish Aramaic at the beginning of a word. See Dalman 1894:97-98, and see next note.

${ }^{29}$ The readings איא, רos, and are all attested in the witnesses. See Lichtenstein 1931-32:322. The latter two are probably corruptions (but see BT Ta anit 12a; Epstein 1948:29-30). I vocalize the same. The former spelling is used in Numbers 30:5,6,8 and 13; the latter spelling is found in Numbers $30: 3,4,5,11,12,13$ and 14, but esar is the form in biblical Aramaic (Daniel 6:8,9,10,13,14 and 16). (yisar) is also a biform of issar (perhaps misread in BT 12a as a verb form, yeyaser). In Palestinian Jewish Aramaic, ' and $*$ are interchangeable at the beginning of a word. See Dalman 1894:97-98, and previous note.
} 
who had already taken upon himself an issar. If I take upon myself an obligation to fast in the context of prayer, and one of these festivals falls out during my fast, the fast overrides the festival, and I am permitted to fast.

The Scroll of Fasting thus uses the term issar in the sense of a selfimposed obligation to fast ${ }^{30}$ undertaken during prayer. ${ }^{31}$ It thus corroborates the usage found in Sifre Zuta, in which the issar of Numbers 30 is said to refer to commitment formulae other than formal oaths and vows, and the "commemorative days" baraita as cited in the Book of Precepts, according to which an issar is a resolution to abstain from meat and wine on a day of mourning. ${ }^{32}$

This interpretation is corroborated by BT Taanit $12 \mathrm{a}$, which cites the last line of the Scroll of Fasting discussed above as evidence for another ruling of Samuel, according to which a fast must be undertaken during the daylight hours of the day preceding the fast:

Samuel said: Any fast that was not undertaken during daylight hours [of the previous day] is not considered a fast.

And if he does fast, what [is the law]?

Rabbah b. Shilah said: He is like a bellows filled with air.

When must he undertake it?

Rav said: At minhah-time [=in the afternoon].

Samuel said: During the minhah prayer service.

Said Rav Yosef: Samuel's position is more convincing, for it says in the Scroll of Fasting: "except someone who has previously undertaken, רoי" [let him forbid/mortify]." Does this not mean "forbid/mortify himself during the prayer service?"

No. [It can simply mean] forbid himself [יאר עצמו].

The Talmud seems to have had a corrupt reading of the last line of the Scroll of Fasting. Instead of להן אנש דאיתי עלוהי מן קדמת דנא איסר/ייסר בצלו "except a person who has previously undertaken an issar in prayer," BT apparently read להן כל אינים רייתי עלוהי מקדמת דנא ייסר/, without the word

\footnotetext{
${ }^{30}$ When a total fast was intended, the usual formula was apparently shall be fasting." See BT Taanit 12a, where this formula is cited in a statement of Rabbi Yohanan. Cf. Nedarim $5 b$, Nazir 2b, and Qiddushin $5 b$, where this formula is considered parallel to the formula הריני מיר, "I am hereby a Nazirite." Tur Orah Hayyim 563 cites the formula הריני בתענית, "I am hereby fasting" in the name of Rabbenu Hananel to Ta'anit 12a, but Rabbenu Hananel in the printed edition of the Talmud has אהז בתענית.

${ }^{31}$ Others translate בצלו as "in a vow," rather than "in prayer." See pseudo-Rashi, ad loc., Dalman 1896:34; Rosenthal 1993:42-43; but see below, note 33.

${ }^{32}$ Although the Scroll of Fasting is clearly referring to a total fast, and not just abstention from meat and wine. See above, note 2 .
} 
בצלו, "in prayer" at the end. "יסר/ "יאסר BT a verb rather than as a variant of the noun issar. ${ }^{34}$

${ }^{33}$ It should be noted that Rosenthal (1993:37-43) cites a variant reading of this passage from a Geonic responsum, which he prefers, according to which Rav Yosef cited the last line of the scroll with the word בצלו as proof for Samuel. According to the talmudic response on behalf of Rava, however, בצלו (which Rav Yosef understood as "let him forbid himself during prayer") could just as well mean מסר בצלו, which Rosenthal emends to "איסר בצלו, "an obligation in a vow." That is to say: Rav Yosef cites in support of Samuel the last words of the Scroll of Fasting, which he interprets as "let him forbid himself during prayer," but the Talmud states that these words could also be read and translated "an obligation in a vow."

This, however, cannot be correct. First of all, צלו simply does not mean vow. Rosenthal cites the prooftext cited by pseudo-Rashi ad loc.: Targum Onkelos to Genesis 14:22, which translates the Hebrew, "I raise my hand to the Lord," as "I raise my hand בצלו to the Lord." Since what follows is an oath, not a prayer, Abraham in the Targum is using the term בצלו in the sense of vow, according to pseudo-Rashi and Rosenthal.

If, however, a vow is not a prayer, it is not an oath either. Translating בצלו as "in a vow" does not help the situation, since what follows is clearly an oath. Moreover, vows are never accompanied by the raising of a hand, as are oaths. The other Targumim have בצלו Instead בשבועה, and if Onkelos wished to refer to an oath, he could have used the correct term. It should be noted that in the Ixar 1490 edition of Onkelos, בשלו was emended to בשלועה, because what follows is an oath, not a prayer. בצלו here would seem to be a reflex of other places in which בצלו hands (Exodus 9:28, 9:33, 17:12).

Rosenthal also cites semantic parallels in Greek and Latin, in which euche and votum, respectively, mean both "vow" and "prayer" (also: "curse"); and Ugaritic, in which the verb צלי means "curse." The translation "curse" is irrelevant to the issue at hand. Euche and votum both refer to sacrificial vows, which were often accompanied by prayer, and hence the semantic development in Greek and Latin. In these cases "vow" is the primary meaning; "prayer" is a secondary development. Rosenthal would have us believe that the opposite is true in Aramaic: the verb צמ can mean "vow," in addition to the usual meaning of "prayer." Thus even if Rosenthal were correct, the Greek and Latin parallels would be mere coincidence, since the semantic development itself is not parallel. Moreover, the proposed semantic development in Aramaic is inexplicable, while the opposite phenomenon in Greek and Latin is easily explained. Rosenthal's claim that means vow thus rests on the evidence of a single instance in Onkelos, in which the usage requires the translation "oath," not "vow." And all this to "explain" the perfectly reasonable statement that fasts must be undertaken during צלו, which is so easily explained in light of a well-attested halakhic tradition according to which fasts are undertaken during the minhah prayer!

(For other cogent arguments against Rosenthal, see Vered Noam's Ph.D. dissertation on the Scroll of Fasting [forthcoming, Jerusalem]. It should be noted that Vered Noam's critique of Rosenthal and my own were developed independently of one another. I would like to express my appreciation for her insights and comments on this issue, as well as those of Adiel Schremer.) 
The first law cited in the name of Samuel in BT Ta anit 12a, namely, that a fast must be formally undertaken during the daylight hours preceding the fast, bears striking resemblence to the original version of Samuel's statement in Shevuot 20a, "providing he vowed on that day," as we have interpreted it. An issar is a resolution to fast, usually on a special commemorative day. As stated above, the unglossed baraita in Shevuot 20a would seem to imply that normally such issarim were undertaken well in advance of the commemorative day in question: the potential faster proclaims that he takes it upon himself to abstain from meat and wine on the day his father died, implying that this day is not imminent. Indeed, the baraita seems to be referring to one who proclaims once, and only once, that he intends to fast every year on the anniversary of his father's death, or the death of Gedaliah, or the day that he saw Jerusalem destroyed. Samuel insists that nonetheless the fast be formally undertaken immediately prior to the fast day each year, or else the undertaking has no halakhic significance. This is very similar to his insistence in BT Ta'anit 12a that a resolution to fast be taken immediately prior to the onset of the fast.

PT Nedarim cites the gloss on the baraita in the name of Rav, inter alia, rather than Samuel. This should not surprise us. BT Ta`anit 12a makes it clear that Rav agrees in principle with Samuel that fasts must be undertaken the previous afternoon. They differ only as to whether this undertaking must be part of the afternoon prayer service. It should be noted that PT preserves a third variant of this restriction, according to

It is clear therefore that בצלו in the Scroll of Fasting means "during prayer." Rav Yosef undoubtedly had this reading in the Scroll, which he cited in support of Samuel. The response of the redactor of the sugya, who omits the word בצלו, is not entirely clear. It may be that he did not have the text of the Scroll before him, and he therefore assumed erroneously that the word בצלו in Rav Yosef's citation of the Scroll was not part of the citation, but rather his own gloss, interpreting the verb as referring to the customary resolution to fast during the afternoon service on the eve of a fast. The Talmud therefore responded to Rav Yosef on Rav's

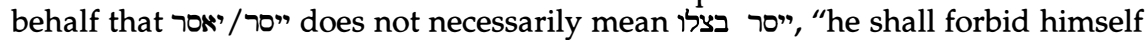
during prayer," but it could also mean, according to Rav יאסר (ye'aser), "[if his vow preceded the promulgation of the Scroll of Fasting], let him be forbidden [to eat,$"$ in keeping with the scholion to the Scroll, cited in BT ad loc.

${ }^{34}$ According to Rosenthal, it was only Rav Yosef who mistook 7 " for a verb. The Talmud itself, which responds to Rav Yosef with the reading רo' (which Rosenthal emends to (איסר), understood that the Scroll was referring to the biblical issar. However, if BT were in fact aware of the reading איסר, and if the connection to the biblical issar were clear to the redactors of BT, then they ought to have taken Rav Yosef's reference to "יס" as a biform of this noun, and not as a verb. BT is well aware of the $/ / \wedge$ switch in Palestinian Aramaic (see notes 28 and 29 above), since it reads in the same line in the Scroll דיית, , דיתי, which is closer to the standard form in Babylonian Aramaic, דאיתא or דאיתי 
which personal fasts, which begin at sunrise, must be undertaken on the evening prior to the fast. This ruling is found in PT Taanit 2:13,66a // PT Megillah 1:6, 70c, which cites the last line of the Scroll of Fasting:

...which teaches that the night is permitted and the daytime is forbidden, in accordance with that which has been taught: "Except a person who has undertaken an issar in prayer."

Rabbi Yose b. Bun said: He must mention it in the evening.

Samuel, Rav, and Rabbi Yose b. Bun all agree that an issar is valid only if undertaken (or reiterated) on the eve of the fast: they differ only as to when exactly on the eve of the fast the issar must be taken. The amoraic statement of BT Shevuot and PT Nedarim, cited variously in the names of Samuel, Rav and Rabbi Yohanan, according to which the issar of the "commemorative days" baraita is only valid if he reiterates it on the fast day itself (באותו היום), thus reflects a widespread amoraic tradition.

To sum up: The word issar was used during the Second Temple period and in the years immediately following in the sense of "resolution to fast." This resolution does not involve any special votive language, and therefore it is binding only if undertaken on the eve of the fast itself: during the evening, according to PT Taanit and Megilla, during the previous afternoon prayer service, according Samuel in BT Taanit 12a, or on the previous afternoon, according to Rav in BT Taanit. The original ביום version of the "commemorative days" baraita, along with the amoraic comment thereon which is variously attributed to Rav, Samuel, and Rabbi Yohanan in BT Shevuot 20a and PT Nedarim 1:1, 36c, defines the biblical issar in accordance with this Second Temple usage of the term issar, and restricts the effectiveness of the issar to cases in which it was uttered immediately prior to the fast (באותו דיום).

\section{[5] The "Issar is an Oath" Baraita}

In addition to the baraita listing the commemorative days, which we have discussed until this point, both Talmudim cite another baraita that attempts to define the biblical term issar. It is cited in PT Nedarim 1:1, $36 \mathrm{c}$, as follows:

Issar is an oath. מבטא is an oath.

If you say issar is an oath, he is liable for each issar and each oath [independently].

If you say issar is not ${ }^{35}$ a type of oath, then he is liable for this [the issar] in its own right and for that [the oath] in its own right.

\footnotetext{
${ }^{35}$ The word "not" is missing from our PT text. Emend with Qorban Ha'edah, as the
} sense and the continuation of the PT passage (see note 42 below) require. 
The baraita is clearly problematic. The first part states unequivocally that issar is an oath, while the second part is not sure. Moreover, the meaning of the second part of the baraita is unclear: the consequences of the two possibilties, "he is liable for each issar and each oath" and "he is liable for this in its own right and for that in its own right," seem nearly identical.

The first question is addressed by the amoraim, in a discussion that immediately follows the citation of the baraita in PT:

You say "issar is an oath," and then you say "if you say...?"

Rabbi Eleazar said: These are two different tannaim [i.e., the baraita is composite].

Rabbi Yirmiyah said: It is one tanna. If he phrases the issar as a vow, you must take it as a vow; if he phrases it as an oath, you must take it as an oath. If he says "issar it is upon me," take it as a vow; if he says "issar and I shall not eat it," take it as an oath.

As we shall see below, Rabbi Yirmiyah's view is cited in BT Shevuot $20 \mathrm{a}$ in the name of the Babylonian amora Rava, to whom it should probably be credited. ${ }^{36}$ According to this view, "if you say issar is an oath," means "if you phrase the issar as an oath," while "if you say an issar is not a type of oath" means "if you do not phrase the issar as an oath, but rather as a vow." This interpretation is clearly far-fetched. Rabbi Eleazar's view, that the baraita is composite, ${ }^{37}$ would seem to be correct. We have already noted that Sifre Bemidbar 153 correctly interprets both the issar ("obligation") and the ("commitment") of Numbers 30 as synonyms for oath, in terse comments nearly identical to the first part of the baraita. It would seem, therefore, that the first part of the baraita, "issar is an oath. mizta' is an oath," is simply a citation of a tannaitic midrash to Numbers $30 .^{38}$

But what is the meaning of the baraita attached to this tannaitic midrash which now forms the second half of the composite baraita? This baraita reads as follows:

If you say issar is an oath, he is liable for each issar and each oath [independently].

If you say issar is not a type of oath, then he is liable for this [the issar] in its own right and for that [the oath] in its own right.

\footnotetext{
${ }^{36}$ See note 51 below.

${ }^{37}$ This answer, akin to the type of interpretation used by modern critical scholars, is typical of Rabbi Eleazar. See BT Shabbat 92b, BT Ketubot 75b, BT Bava Qamma 48b and BT Bava Metsi a 82b, inter alia. In BT, Rabbi Eleazar uses the expression: "break it apart. He who taught this [the first part] did not teach this [the second part]."

${ }^{38}$ See Epstein 1948:300, note 2.
} 
The consequences of the two options seem, at first glance, to be nearly identical: "he is liable for each issar and each oath" sounds a lot like "he is liable for this independently and for that independently." 39 However, there is no doubt as to the reading in PT, since PT quotes the two possibilities once again later on the sugya, and goes on to analyze each in depth.

What then is the meaning of the two alternatives introduced in the PT version of the baraita with the phrase "if you say?" The phrase "if you say" is quite common in PT, where it is used both to introduce a simple indicative statement, "if you say $x$, then $y$ follows," and to introduce a question, "if you say $x$ [as you just did], then $y$ follows [and $y$ is impossible]." However, the phrase is very rare in tannatic literature. It occurs only six times other than in our case. ${ }^{40}$ In five out of the six cases, it is used to introduce a question. In the sixth case (Sifra Shemini, Chapter 11, paragraphs 3-4), it is used to introduce two alternatives, as in our baraita. The two alternatives in that case are two alternative interpretations of a biblical verse, Leviticus $11: 38,{ }^{41}$ and it would seem

\footnotetext{
${ }^{39}$ This is probably the reason that the baraita is cited in BT in truncated form: the tradent responsible did not understand the last words of the baraita, so he simply lopped them off. See below, section 6 .

${ }^{40}$ Sifra Shemini Chapter 11, sections 3-4 (see citation below); Sifra Zavim parashah 5, section 7; Sifra Emor Chapter 12, section 2; Sifre Bemidbar 8 // PT Sotah 4:4, 19c; PT Sotah 3:4, 18d; and BT Menahot 64a // BT Menahot 68b.

${ }^{41}$ The Sifra passage reads as follows:
}

"But if water is put on the seed and any part of a carcass falls upon it, it shall be unclean for you" (Leviticus 11:38)...

If you say produce attached to the ground is [capable of becoming ritually] unclean [when touched by water], but detached produce is clean, then you have deemed everything unclean,

but if you say attached produce is clean and detached is unclean, then you have deemed some unclean and some clean;

if you say that [produce brought into contact with water] by heaven is clean, but [produce brought into contact with water] by man is unclean, then you have deemed everything unclean,

but if you say that by heaven it is unclean and by man it clean, then you have deemed some unclean and some clean.

In this passage, unlike in our baraita, the presentation of the two alternatives ("if you say...but if you say...") is a rhetorical device. The first alternative is by implication rejected as being unrealistic, and only the second is to be taken seriously. This may be the reason that the two alternatives are presented in the Sifra in a manner slightly different from that of our passage: our baraita has "if you say... if you say...," while Sifra to Leviticus 11:38 has "if you say...but if you 
that the same is true of our baraita: the two alternatives are two midrashic interpretations of Numbers 30:3:

If a man vows a vow to the Lord, or takes an oath imposing an obligation (השבע שבועה לאסר אסר) upon himself, he shall not break his word; he must carry out all that has crossed his lips.

We have already seen that the first part of our composite baraita is a midrash on Numbers $30: 3$; the second part of composite baraita is a further midrash on the same verse. Like the midrash on Leviticus 11:38, this midrash also distinguishes between two alternate interpretations of the biblical verse in question. The words לאסר are prima facie superfluous, since it is clear from the context that the oath referred to is an oath imposing obligation. Why then did the Torah specify ראר "imposing an obligation?" There are two possiblities, according to our midrash: either issar is a synonym for oath, or it is an independent institution. If issar is a synonym for oath (as per the plain meaning of Scripture, Sifre Bemidbar, and the first half of the composite baraita), then, reasons our midrash, the Torah juxtaposed two synonyms in order to teach that if one breaks more than one oath/issar, he is liable independently for each. ${ }^{42}$ If, however, an issar is not a type of oath, then, reasons our midrash, the Torah mentioned both oath and issar in order to teach that if a person breaks both an oath and an issar he is liable independently for each. ${ }^{43}$ According to this interpretation, however, we cannot conclude from this verse whether one is liable more than once for breaking more than one oath or more than one issar.

If an issar is not an oath, as per the simple meaning of Scripture, Sifre Bemidbar, and the first half of our composite baraita, then what is it? Rabbi Yirmiyah in PT assumes that if an issar is not an oath then it must be a vow (i.e., a vow formulated with the word issar). However, in view of the well-attested Palestinian usage of the term issar to refer to a nonformulaic resolution to fast, it is far more likely that the alternative "if you say that issar is not a type of oath" in our baraita/midrash refers to this well-known Palestinian concept. The author of the baraita does not need to specify that the alternate interpretation of issar is a resolution to

say" or according to some witnesses "if you say...once you say." However, even in the Sifra, both alternatives are hypothetical interpretations of Leviticus 11:38.

${ }^{42}$ Further on in the PT sugya (in a section not cited in this chapter), the baraita is said to refer to a case in which more than one oath are applied to a single item. See PT Nedarim 1:1, 36d (top).

${ }^{43}$ Further on in the PT sugya (see citation below, section 6), the baraita is said to refer to a case in which an oath and a vow (issar = vow according to this interpretation in PT) are applied to the same item. 
fast, because this was the common usage of the term in his day, and the interpretation would have been obvious to his audience.

\section{[6] Amoraic Interpretations of the Term Issar}

Two interpretations of the word issar in Numbers 30 were thus current during the tannaitic period. The first interpreted the word as a synonym for "oath," or, more precisely, "future-tense oath," in accordance with the plain meaning of Scripture. This interpretation is found in Sifre Bemidbar, a Midrash of the school of Rabbi Ishmael, according to whom the Torah makes use of human language, and therefore a synonym or modifier does not necessarily have halakhic significance.

A second school of thought, however, simply could not accept the notion that a word repeated so often in Numbers 30 is a mere synonym for oath; this school therefore sought a distinct yet specific meaning for the term issar. In view of the usage of the verb איסור in and the noun rabbinic Hebrew in the sense of "prohibit, prohibition," the notion developed that the biblical issar is a self-imposed "generic" prohibition that does not make use of any particular vow or oath terminology. This development took place already prior to the destruction of the Second Temple, and the Scroll of Fasting assumes that its readership is familiar with the איסר בצלו, "a resolution to fast undertaken during prayer." Because the language of the issar does not, ipso facto, imply any sanction in case of violation (as does the language of oaths and vows), a legal tradition developed which limited the effectiveness of an issar to specific circumstances; namely, when it is proclaimed immediately prior to the fast day in question (according to the Babylonians, in the afternoon; according to the Palestinians, in the evening), and, according to Samuel and Rav Yosef, only when it is a formal part of the prayer service on the eve of the fast. This tradition is alluded to in the Scroll of Fasting itself, and is also recorded in the Palestinian and Babylonian Talmudim. However, there is a difference between the traditions as recorded in the two Talmudim: PT is aware of the fact that the institution under discussion is known as issar, while BT refers to the resolution as קבלת תענית and is unaware that the last line of the Scroll of Fasting refers to the institution known as issar that developed in the course of the exegesis of Numbers 30.

The first generation of amoraim in both Palestine and Babylonia were well aware of the usage of the term issar in the sense of "resolution to fast," as is clear from the amoraic comment (attributed variously to Samuel, Rav, and Rabbi Yohanan), according to which an issar resolution is valid only if taken on the day of the fast, that is, immediately prior to 
the onset of the fast. This is also apparently the sense in which we should interpret the word issar as it appears in the following third-century Palestinian amoraic dispute (PT Nedarim 1:1, 36c):

Rabbi Jacob b. Aha said: Rabbi Yohanan and Rabbi Eleazar disputed the following point. Rabbi Yohanan said one is not $^{44}$ flogged for [breaking] issarot. Rabbi Eleazar said one is flogged.

We cannot interpret the word issarot here either in the sense of "oaths" (in accordance with the plain meaning of Numbers 30), nor in the sense of "vows" (in accordance with the dominant late amoraic Palestinian usage ${ }^{45}$ ). Both of these institutions are mentioned explicitly in Numbers $30: 3$, and therefore in either case it should be obvious that violation is punishable by flogging, as is the case with all negative commandments whose penalty is unspecified. The only interpretation of the word issarot that makes sense here is "resolutions to fast." Rabbi Eleazar believed that the issar mentioned in Numbers 30:3 was the issar of his day, namely, a resolution to fast, and therefore the penalty for breaking such a resolution is flogging. Rabbi Yohanan, who of course was also aware that in the rabbinic language of his day the term issar was used in the sense of resolution to fast, nonetheless did not believe that the word issar in Numbers 30 referred to this type of informal undertaking. He therefore felt that a resolution to fast without any special terminology was not technically binding according to Torah law, and its violation is not punishable by flogging. Rabbi Yohanan presumably interpreted the issar of Numbers 30 as a synonym for oath, in accordance with the plain meaning of Scripture and Sifre Bemidbar.

Following the first generation of amoraim, throughout the first half of the amoraic period in the third and early fourth centuries, the use of the term issar in the sense of resolution to fast was still current in Palestine. However, it was completely forgotten in Babylonia. Because this usage was not current in Babylonia, the Babylonian amoraim were faced with a vacuum of interpretation waiting to be filled: what is the issar mentioned in the Torah? The two baraitot defining the term issar were poorly preserved in Babylonia, in part because both refer (directly or indirectly ${ }^{46}$ ) to the definition of issar in the sense of "resolution to

\footnotetext{
${ }^{44}$ In the extant texts, the positions are reversed: Rabbi Yohanan says that one is liable, while Rabbi Eleazar says that he is not. In PT Nazir 1:1, 51a, however, the positions are cited in reverse, and the context there makes it clear that this is the correct reading. We have therefore translated the text as emended by the commentators, which see ad loc. in Nedarim.

45 See below, section 7 of this chapter.

46I refer here to the original ביום version of the "commemorative days" baraita, according to which the word issar is clearly defined as a resolution to fast. In the original PT version of the "issar is an oath" baraita, this interpretation is alluded to
} 
fast," a sense that was lost on the Babylonians. The "commemorative days" baraita, which originally defined the issar as a resolution to fast on a commemorative day, such as the anniversary of a death, was not completely understood, because the Babylonians were unaware that this type of resolution was considered by some to be the biblical issar. ביום was therefore corrupted to כיום, a reading which eventually became standard in Palestine as well, as can be seen from PT Nedarim 1:1, 36c, and most witnesses to Tosefta Nedarim 1:4.

The Babylonian attempts to invest the term issar with meaning are recorded in BT Shevuot 20a:

Our Rabbis taught [in a baraita]:

פבטה is an oath. Issar is an oath.

The prohibition ${ }^{47}$ of an issar: If you say issar is an oath, then he is liable, but if not, then he is not liable.

"If you say issar is an oath?" You just said issar was an oath! ${ }^{48}$

Said Abaye: The baraita should be understood as follows: מבטא is an oath. Issar is likening to an oath. The prohibition of issar: If you say that likening to an oath is tantamount to uttering an actual oath, than he is liable, but if you do not, than he is not liable.

Rava said: I say to you that likening to an oath is most assuredly not tantamount to uttering an actual oath. The baraita should be understood as follows: מבט is an oath. Issar is also an oath. The prohibition of an issar was mentioned in Scripture (Numbers 30:3) between oaths and vows, in order to teach that if he phrased the issar as a vow, it is considered a vow, and if he phrased it as an oath, it is considered an oath.

Armed with the כersion of the "commemorative days" baraita, Abaye was able to provide an interpretation of the term issar in Numbers 30 , our "term in search of meaning." Abaye explained that an issar is "likening to an oath," the precise analog of the qonam in the world of

with the phrase "if you say issar is not a type of oath." The author assumed his audience would know that if issar is not a synonym for oath, it is a resolution to fast. See above, section 5 .

${ }^{47}$ Hebrew: איסור. A number of witnesses, including the medieval commentator Rabbenu Hananel, read אסר אסר איסר איסר איסר. This is probably only an orthographic variant. However, Rabbenu Hananel developed his own interpretation of the baraita which revolves around this reading. See his commentary to Shevuot $20 \mathrm{a}$, and Tosafot s.v. issar.

${ }^{48}$ The Munich 95 manuscript of BT and some of the medieval commentators read the general question מאי "what does this mean?," instead of the question as cited here. This is probably a secondary reading. A scribe was disturbed by the fact that Abaye does not really seem to answer the question as phrased in BT (see below), and he therefore emended the text so that the question is not quite so specific. 
vows. Just as a qonam likens hitherto permitted property to property prohibited by a preexistent vow of dedication, so an issar likens the swearer's postion vis-a-vis a given item to his position vis-a-vis an item previously forsworn. Abaye then read this definition of issar into the other baraita, reinterpreting the simple statement "issar is an oath" as "issar is likening to an oath."

Abaye's colleague, Rava, also felt the need to find an interpretation of the word issar as it appears in Numbers 30 and in the "issar is an oath" baraita. However, unlike Abaye, Rava was apparently unfamiliar with the "commemorative days" baraita in either the ביום version. He thus had no evidence that would allow him to interpret the issar as either a resolution to fast (as per Palestinian usage) or as "likening" to an oath. He therefore proposed that issar be taken as a votive formula in its own right. If phrased as a personal prohibition ("issar I shall not eat"), it takes on the character of an oath, with the term issar substituted for the term shevu ah. If phrased as a ban on an object (issar is this loaf to me), it takes on the character of a qonam vow, issar replacing the word qonam.

Rava's position is apparently based on the "issar is an oath" baraita as cited in PT:

Issar is an oath...

If you say issar is an oath, he is liable for each issar and each oath; if you say issar is not a type of oath, he is liable for this in its own right and for that in its own right.

Rava was disturbed by the question asked in both Talmudim: why does the first part of the baraita state categorically that issar is an oath, while the second part reopens the question? Rava's solution is to reinterpret the latter part of the baraita. According to Rava, "if you say issar is an oath" actually means "if you phrase the issar as an oath;" while "if you say issar is not a type of oath" actually means "if you phrase the issar as something other than oath," namely, a vow.

The version of the "issar is an oath" baraita found in BT,

מבטN is an oath. Issar is an oath.

The prohibition of an issar: If you say issar is an oath, then he is

liable, but if not, then he is not liable,

is simply a truncated version of the original PT text, with minor variations. Abaye probably received the baraita in an even more truncated form:

מבטא is an oath. Issar is an oath.

If you say issar is an oath, he is liable,

consisting only of those words common to the PT and BT versions. The continuation of the baraita as it appears in PT, "for each issar and each 
oath; if you say issar is not a type of oath, he is liable for this in its own right and that in its own right," was apparently unintelligeable to the tradent responsible for the version Abaye recieved, and he therefore lopped off the end.

Abaye, who received this truncated version of the baraita, was familiar with the כיום version of the "commemorative days" baraita, which, as we have seen, seems to refer to the issar as a type of "likening" akin to a qonam. Abaye therefore "filled out" the truncated version of the "issar is an oath" baraita as follows:

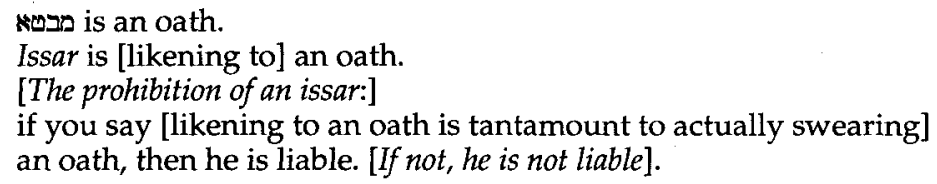

The words in brackets are those that Abaye added to the truncated baraita. The underlined words within the brackets, although originally part of Abaye's interpretation, were incorporated by the editor of the talmudic passage into the initial citation of the baraita itself, since the version that Abaye and the editor had before them was clearly defective. ${ }^{49}$

Abaye's interpretation of the baraita was not originally offered in response to the question "'If you say issar is an oath', but you just said 'issar is an oath'!," as presented in BT. In fact, Abaye's comment does not really answer this question at all. ${ }^{50}$ Abaye's comment was originally a

${ }^{49}$ As a result, the sugya as a whole is confused, since Rava is presented as interpreting the phrase "if not, he is not liable" in the baraita in the sense of "if it is not an oath but a vow, he is liable as if for a vow." In fact, however, the words "if not, he is not liable" are Abaye's addition to the truncated baraita, while Rava probably had the original ending, "if you say issar is not a type of oath, he is liable for this in its own right and for that in its own right," which Rava paraphrases as "if he phrased the issar as a vow, it is considered a vow."

${ }^{50}$ The medieval commentators went to great lengths to explain how Abaye answers BT's question. For a survey, see Benovitz 1993:77-78. Here we shall limit ourselves to a discussion of Rashi's approach. Rashi explains Abaye's interpretation of the baraita in a rather unusual manner, namely: The formula " Iבטא I shall not eat this loaf" is an oath formula, while the formula "issar I shall not eat this loaf" is a "likening to an oath" formula, tantamount to saying "this loaf is like a loaf from which I am already forsworn." If likening to an oath is a legitimate concept, then the issar formula works; if likening is not a legitimate concept, then the issar formula does not take effect.

This interpretation is based upon Rava's interpretation of the baraita in BT Sheuvot 20a (see below), and Rabbi Yohanan's paraphrase of the baraita in BT Shevuot 20b: "מבטא I shall not eat your food is an oath; issar I shall not eat your food is an oath." According to both Rabbi Yohanan and Rava, the issar and of the baraita are oath formulae. Rashi, who was troubled by the fact that Abaye 
free-standing interpretation of the truncated "issar is an oath" baraita in light of his reading and understanding of the "commemorative days" baraita. This interpretation was not initially intended to reconcile the discrepancy between the first and second parts of the "issar is an oath" baraita. In fact, it would seem that Abaye considers the "issar is an oath" baraita composite (as does Rabbi Eleazar in PT), or, more precisely, he considers it two-tiered: it consists of the citation of a position and the evaluation of that position. The baraita, as filled out by Abaye, cites the view that the issar of Numbers 30 , for which one is liable, is likening to an oath. It then goes on to state that this is the case only according to those who consider likening to an oath a valid procedure.

\section{[7] Issar as the Standard Term for Vow in Fourth-Century Palestine}

Rava's interpretation of the term issar and the "issar is an oath" baraita, according to which issar is a votive formula that can be used as either an oath or a vow, was brought to Palestine by his contemporary Rabbi Yirmiyah. ${ }^{51}$ It would seem that at about this time, the usage of issar in the sense of "resolution to fast" began to fade even in Palestine, and issar thus became "a term in search of meaning" in Palestine as well. As we have seen, oaths, whether explicitly in God's name or using the rabbinic formula sheou ah, were generally avoided, because of a popular fear that was reinforced by rabbinic disapproval. Vows were commonly used as oath substitutes, and even in these the original formula qorban was replaced by the substitute formula qonam. This substitute formula originally had a meaning, but by the amoraic period this meaning was

differed with Rava and Rabbi Yohanan on so basic an issue as what an issar is, reads this interpretation into Abaye's view as well. In so doing he must maintain that the issar formula does not count as a real oath, but only as "likening to an oath," and its effectiveness depends upon how one views the likening process. This is incomprehensible: there is no reason at all why the formula issar used in actual oath should be linked to the likening process. Moreover, it is clear that the phenomenon described by Abaye is the same as the one described in the version of the "commemorative days" baraita, which also clearly served as the source for Abaye's connection between issar and "likening." Therefore, when Abaye says "issar is likening to an oath," he clearly means that the issar of Numbers 30 consists of likening to an oath, as per the כיום version of the "commemorative days" baraita.

${ }^{51}$ We do not have solid evidence that the interpretation cited in BT in the name of Rava and in PT in the name of Rabbi Yirmiyah is originally Rava's rather than Rabbi Yirmiyah's. However, this seems more likely, since Rabbi Yirmiyah emigrated from Babylonia to Palestine, and Rava knew him in Babylonia. However, Rava and Abaye were said to have received word of him even after his emigration (see BT Ketubot 75a), and it is possible, though rather unlikely, that Rava heard of an interpretation that Rabbi Yirmiyah gave in Palestine, and transmitted in Babylonia. 
forgotten, and the gonam was considered a nonsensical play on the word qorban. ${ }^{52}$ Rava's ruling, brought to Palestine by Rabbi Yirmiyah, according to which the biblical word issar could be used as a valid vow formula, fell on fertile ground. Issar was felt by the public to be far preferable to the nonsensical formula gonam, both because of its biblical origin and its similarity to the word issur, "prohibition," so common in rabbinic Hebrew and Aramaic. ${ }^{53}$ Issar soon replaced qonam as the Palestinian vow formula, and vows became known as issarot rather than nedarim or qonamot. 54

In addition, three Palestinian texts from the tannaitic and early amoraic periods, in which issar had been used in what was then the usual Palestinian sense of "resolution to fast," were reinterpreted in light of the late amoraic Palestinian usage of issar as synonym for vow. These texts are the "commemorative days" baraita, the "issar is an oath" baraita, and the dispute between Rabbi Yohanan and Rabbi Eleazar concerning liability for flogging in case of violation of an issar.

Let us begin by citing the PT discussion of the "commemorative days" baraita. We cite the text of the baraita again, along with the ensuing amoraic comments:

What is an issar? This loaf is to me like the day (כיום) that father died, like the day so-and-so was killed, like the day that I saw Jerusalem destroyed. That is the issar referred to in the Torah.

Rabbi Ba in the name of Rabbi Yohanan and Rav; both say: This is only if he vowed on that day (באות היום).

Rabbi Yose asked: if he took a vow on that day, why do I need an issar? Let him say "like that day."

\footnotetext{
${ }^{52}$ See detailed discussion of the etymology of the qonam formula below, Chapter 4.

${ }^{53}$ It is possible that the amoraic gloss on the "commemorative days" baraita cited variously in the names of Samuel, Rav, and Rabbi Yohanan (see above, section 3), was another catalyst for the spread of the usage of issar in the sense of vow in late-third-century Palestine. The amoraim state that an issar is valid "only if vowed on that day." Originally the word "vowed" was probably used as a catchall term instead of "uttered an issar." But the fact that the verb רדו, "vow," is used in this statement to refer to an issar may have led people to believe that it was an alternate vow formula, like gonam.

${ }^{54}$ See PT Nedarim 4:2,38c, where the phrase מעל באיסרות ("he is liable for trespass against Temple property if he violates vows) is used instead of the parallel בקונמות in the parallel passage in BT Shevuot 22a, and PT Nedarim 1:1, 36d (the end of the discussion of the issar in PT, not cited here), in which issar is used repeatedly in a catalogue of vows as the standard vow formula. Note that the text of this passage is corrupt in all standard editions. Better readings are found in Nahmanides' citation of the passage in his comment on Nedarim 16b, but see Benovitz 1993:626, note 34 .
} 
As we have seen, the baraita originally read ביום instead of and it originally referred to a self-imposed fast. This was also the intention according to the amoraim cited by Rabbi $\mathrm{Ba}$, who insisted that the resolution to fast be "vowed" (i.e., undertaken) immediately prior to the fast, "on that day." However, the text was later corrupted to כיום, and interpreted as likening a new undertaking to a prior fast. Rabbi Ba's citation was reinterpreted to mean that the issar takes effect only if the original fast "on the day father died" was enshrined in a vow. If the original fast was vowed, then the new fast linked to the old also has the status of a vow.

The fourth-century amora Rabbi Yose was familiar with the baraita and the ensuing comment in their secondary form, with the reading in the baraita. Rabbi Yose is therefore puzzled, because issar in his day was the normal word for vow. He therefore assumed that when the baraita says, "What is an issar? This loaf is to me like the day my father died," the votive formula issar is omitted in the citation of the vow because it is self-understood. The baraita's example of an issar is therefore simply an example of a vow: "What is an issar? [Issar] is this loaf upon me like the day my father died." The formula "issar is this loaf upon me" is a classic vow formula, and it is binding in its own right, even without the comparison to the commemorative day. Rabbi Ba's citation is therefore unintelligible to Rabbi Yose: why insist that the votary be obligated by vow to fast on the commemorative day before linking another vow to the original one, if the new vow is a complete votive formula in its own right? This is the meaning of Rabbi Yose's statement: if he had indeed vowed on the original day, why do I need a new vow (issar)? Let him say "[This bread is upon me] like that day," rather than "issar is this bread upon like that day"! 55

Rabbi Yose therefore differs with what he believes the amoraim cited by Rabbi Ba are saying, and insists that the baraita is not referring to a comparison of a new vow to a former vow, but rather to a simple vow formula. The commemorative days are merely decorative: the binding formula of this and all issarot is simply "issar is this loaf upon me."

\footnotetext{
${ }^{55}$ Of course, this is precisely what the votary says: "This loaf is upon me like the day...." But, as stated above, because this statement is referred to in the baraita as an issar, Rabbi Yose assumes that the word issar is to be read into the beginning of the statement.

Lieberman (1967:403, note 39) interprets Rabbi Yose's question slightly differently. According to Lieberman, Rabbi Yose does not supply the word issar in the formula itself, but rather wonders why the vow is not considered a yad, or "handle" on an issar, i.e. an elliptical formulation in which key words are left out, but which is nonetheless valid (see Mishnah Nedarim 1:1).
} 
The second baraita, "issar is an oath," was also reinterpreted during the latter part of the amoraic period in accordance with the then current usage of issar in the sense of vow, as is attested by the following sugya which comments upon the latter part of the baraita (PT Nedarim 1:1, 36d):

If you say issar is not a type of oath, then he is liable for this [the issar] in its own right and that [the oath] in its own right.

Rabbi Yudan said: This is only if he uttered the oath and then the vow, but if he uttered the vow and then the oath, ${ }^{56}$ vows take effect even with regard to prohibited items, but oaths do not take effect with regard to prohibited items. ${ }^{57}$

The fourth-century Palestinian amora Rabbi Yudan assumes that the baraita comes to teach that he is liable for oaths and vows independently. According to Rabbi Yudan's interpretation, the baraita is referring to a case in which an oath and a vow ("issar") are applied to the same item, for example: "I swear that I will not drink wine; issar is wine upon me." If he swears and then vows with regard to the same item, he is liable for each independently. If he vows and then swears, the oath simply does not take effect at all.

Rabbi Yohanan and Rabbi Eleazar's dispute regarding the penalty for violating an issar, which we have already interpreted as referring to resolutions to fast, was also reinterpreted by late third- and fourthcentury Palestinian amoraim as referring to vows, in accordance with late Palestinian usage of the term issar which was projected onto the early amoraim (PT Nedarim 1:1, 36c):

Rabbi Jacob b. Aha said: Rabbi Yohanan and Rabbi Eleazar disputed the following point. Rabbi Yohanan said one is not liable to flogging for [breaking] issarot. Rabbi Eleazar said one is liable to flogging.

Said Rabbi Jacob b. Aha: This is how Rabbi Yohanan would refute Rabbi Eleazar: According to your opinion, that one is liable to flogging for breaking issarot, does the Mishnah not teach, "If one is barred by vow from benefitting from his friend, and he goes to visit him [(at his sickbed), he may stand but not sit] (Mishnah Nedarim

\footnotetext{
${ }^{56}$ In our editions, the reading is "the vow and then the oath... the oath and then the vow," rather than the reverse. But this reading makes no sense, since vows can be applied to oaths or other vows, but oaths do not take effect when applied to items previously forsworn. See Mishnah Nedarim 2:3; Mishnah Shevuot 3:7. This translation therefore follows the emendation of Pene Moshe ad loc.

${ }^{57}$ Note that the word that we have translated "prohibited items" is the Hebrew איסורין But this reading makes no sense in this context. The word should be "prohibited items." The scribal error is quite understandable, in view of the context.
} 
4:4)? [If an issar, or vow, is punishable by flogging,] he ought not go visit at all!

Said Rabbi Yirmiyah: That case is different, because of "the ways of peace" [in other words, visiting the sick is permitted even to a person banned by vow, because it is an act of kindness to one in need].

Rabbi Yose asked: If because of "the ways of peace," it ought to be permitted even [to one banned] by oath, and yet it was taught: "it is permitted under vow, but not under oath."

In this discussion, Rabbi Jacob b. Aha, Rabbi Yirmiyah, and Rabbi Yose all assume that the issarot under question are vows, in accordance with the late Palestinian usage introduced by Rabbi Yirmiyah himself, and not resolutions to fast. They thus reinterpret an early third-century dispute in light of late third-century usage.

To sum up: the word issar, mentioned repeatedly in Numbers 30, simply means "obligation." In that context, it is used to refer to futuretense oaths. In late Palestinian usage, it comes to mean vow. On the road from oath to vow the term was used in at least one other sense: a resolution to fast. The term was also interpreted (though probably never actually used) in two other senses: Abaye, basing himself on a corrupt reading in a baraita, interpreted the issar as a secondary oath attached to a primary oath by "likening." Rava viewed the issar of Numbers 30 as a votive formula that can take on the meaning of either an oath or a vow. While neither of these Babylonian interpretations is attested in actual usage, the latter gave rise to the late Palestinian usage of issar as the standard term for vow, and the standard vow formula, in fourth-century Palestine. 


\section{HEREM: The Communal Vow}

\section{[1] Various Meanings of the Word Herem}

The term herem, like the term issar discussed in the previous chapter, is used in a number of different senses in biblical and rabbinic Hebrew. ${ }^{1}$ In this case, however, most of the senses are found in the Bible, and therefore the greater part of this chapter will be devoted to biblical, rather than rabbinic, usage.

The noun herem (often translated "ban") and the verb החרים (usually translated "ban" or "proscribe"), are used in two senses in the Hebrew Bible. A herem is a type of dedicatory vow, similar to the dedicatory neder in all respects except that it is irrevocable and unredeemable (Leviticus 27:28a), but herem can also mean total destruction, usually in the context of war or the annihilation of idolaters. In Second Temple sources a herem seems to be a type of pact, binding conspirators to carry out their mutual plan. $^{2}$

Two further meanings are attested in rabbinic literature:

\footnotetext{
${ }^{1}$ In addition to the meanings of the root used in the following senses in biblical and rabbinic Hebrew: חרים, "fishnet;", "fisherman;" חרם, "tax collector," and $\pi$, "canal, body of water." These words do not derive from the Semitic root חרם "The words for "fishnet" and "fisherman" are probably derived from the root "ח " "tax collector," see Lieberman and Kutscher 1963. For "canal, body of water," see Lieberman 1962:1011. In Syriac the root חרם is used with the meaning "savage" (חורמא also means "snake"), but this meaning derives from the Semitic root ערם The same may be true of the Arabic hirmah/haramah, "sexual desire (particularly of female animals)." For the Akkadian uses of the Semitic roots of which are likewise irrelevant to the ensuing discussion, see below, note 115 . The root $\pi$ in languages which distinguish between $\pi$ and ' $\pi$ (Ugaritic and חרמים Arabic) should not be considered in a discussion of the biblical and rabbinic (pace Stern 1991:13-16).

${ }^{2}$ E.g. I Enoch 6:4 (=4QEna iii, line 5); Acts 23:12. See below, section 6.
} 
(1) In Chapter One, we saw how the biblical dedicatory neder developed into the rabbinic prohibitive neder. The herem formula is likewise attested in rabbinic literature as a prohibitive formula, but its precise nature is not clear. Mishnah Nedarim 2:4, for example, mentions as a vow formula, akin to the rabbinic prohibitive vow likening property that was hitherto permitted to Temple property. ${ }^{3}$ But the next mishnah, Nedarim 2:5, refers to one who vows "by a herem," a construction usually associated with oaths. ${ }^{4}$ Mishnah Nedarim 5:4 seems to refer to another type of prohibition formula using the word herem: the votary declares his neighbor herem vis-a-vis himself. This declaration resembles neither an oath nor a vow, since the subject of the sentence is a prohibited person, not a prohibited object (as in a vow), or the swearer himself (as in an oath).

(2) In amoraic literature, the word is used to refer to a type of excommunication, a meaning attested only in late Aramaic dialects and in late Rabbinic Hebrew of the amoraic and post-amoraic periods. ${ }^{5}$ Some scholars believe that this meaning is based loosely upon Ezra 10:8: "anyone who did not come in three days would, by decision of the officers and the elders, have his property devoted (יחרם כל רכושו) and himself excluded (יבדל) from the congregation of the returning exiles." 6 Although this verse clearly distinguishes between the fate of the truant's property and his person, and although only the former is referred to with the verb $ם$, These scholars believe that herem came to mean excommunication because the two concepts were associated in this verse. A further development of this meaning occurs in post-talmudic halakhic literature: the noun herem comes to refer to a type of communal legislation (תקנת הקהל). ${ }^{7}$ The usual explanation is that this is an expansion of the "excommunication" meaning, since the violation of this type of communal decision is punishable by excommunication. ${ }^{8}$

In other Semitic languages, the root rimply means "holy," and thus "forbidden for common use." 9 This meaning clearly lies behind the

\footnotetext{
${ }^{3}$ See above, Chapter 1 , section 1 .

4 See Lieberman 1942:128, and below, Chapter 5 .

${ }^{5}$ See below, section 6 .

6Malamat 1961:149; Cohn 1971:344. But see below, section 6 .

${ }^{7}$ See sources cited by Baer 1950:24, note 26; Albeck 1960:102.

${ }^{8}$ See below, section 9 .

${ }^{9}$ Thus in Old South Arabic, Classical Arabic, and Nabatean. See Biella 1982:189-

190; Lane 1863-1893, s.v. חרם; Hoftijzer and Jongeling 1995:405. The root is also found as an element in many Semitic names (Stern 1991:17), but it is not clear to what extent this indicates sacral usage.
} 
biblical use of the term herem in the sense of an irrevocable dedicatory vow. However, the etymology of the other meanings is not at all clear: How did herem come to mean the destruction of enemies and idolaters in biblical Hebrew, a meaning which is ostensibly far removed from the sense of "holy," if not its opposite? And what is the nature of the herem mentioned in Second Temple sources and the herem of the Mishnah? Are they identical? If so, is this type of herem a prohibitive vow formula, a type of oath, or something else? How did this meaning evolve? We have seen in Chapter One that the dedicatory neder of the Bible gradually evolved into a prohibitive formula, and we have found evidence of an interim usage of neder as a vow dedicatory in form but prohibitive in meaning in Second Temple sources. Can the rabbinic attestations of herem as a type of self-imposed prohibition be explained in the same way? And what of excommunication? How did this meaning develop from the root sense of "holy?"

\section{[2] Herem as a Communal Wartime Offering}

G. R. Driver has suggested that two distinct proto-Semitic roots, חרם and $\pi$, underlie the two senses of the word herem in biblical Hebrew. ${ }^{10}$ The root חרם is attested in many Semitic languages in the sense of "holy,"11 and this is clearly the root that underlies the biblical votive herem. But according to Driver, the herem of destruction derives from the root $\pi$, which in many Semitic languages, including Hebrew, has the sense of "cut."12 However, this view has correctly been disputed by other scholars. ${ }^{13}$ Biblical texts from the earliest through the latest periods make it clear that herem does not simply mean total destruction, but rather total destruction as an offering to God. ${ }^{14}$ Thus we read in the early conquest

\footnotetext{
${ }^{10}$ Driver 1967:56-59. His thesis is accepted by Stern 1991:16 with regard to some of the less clearly "sacral" examples of חר in the Bible. See below, note 14.

${ }^{11}$ See note 9 above.

${ }^{12}$ Cf. Biblical Hebrew חרום, "slit, mutilated" (Leviticus 21:18).

${ }^{13}$ See Lohfink 1986:188-189, and Niditch 1993:40-42, who critiques other scholars who deny the sacral nature of the herem. And see next note.

${ }^{14}$ Stern insists that the root $\pi$ as it appears in the context of warfare in the following passages has no sacral connotation, and therefore derives from $\square$ ' $\pi$, not חר: II Kings 19:11 = Isaiah 37:11; Jeremiah 50:21 and 51:3 (but not 50:26!); Daniel 11:44 and II Chronicles 20:23. See Stern 1991:185-187, 199-200, 213-215. He argues that the Assyrians, the enemies of Babylon, the Ammonites and Moabites, and Antiochus Epiphanes would not have considered their wartime destruction sacred. But this argument confuses history with literature: it is not necessary to posit that the foreign kings themselves actually conducted a herem; it is the authors of these verses who considered certain wartime devastation herem. Stern is willing to admit that the author of Jeremiah 50:26 describes the fall of Babylon in cosmic terms as a herem, because other "chaos vs. order" terminology occurs in
} 
narratives of Numbers 21:1-3 and Joshua $6: 17-19,15$ of conquered cities that are placed under herem "for the Lord":

Then Israel made a vow to the Lord and said, "If you deliver this people into our hand, we will make their town herem." The Lord heeded Israel's plea and delivered up the Canaanites; and they and their cities were made herem. So that place was named Hormah. (Numbers 21:2-3)

Joshua commanded the people, "Shout! For the Lord has given you the city. The city and everything in it are to be herem for the Lord...but you must beware of the herem, or else you will be herem; if you take anything from that which is herem, you will cause the camp of Israel to be herem; you will bring calamity upon it. All the silver and gold and objects of copper and iron are consecrated to the Lord; they must go into the treasury of the Lord." (Joshua 6:1619)

The above narratives are usually ascribed to the tenth or ninth century B.C.E. This usage of the word herem continues during the period of classical prophecy (eighth century B.C.E.):

Up and thresh, fair Zion! For I will give you horns of iron and provide you with hoofs of bronze. And you will crush the many peoples. You will make their riches herem for the Lord, their wealth for the Lord of all the earth. (Micah 4:13) 16 $^{16}$

close proximity (Stern 1991:200). Why then is it necessary to posit the existence of a different root חרם, used by the same prophet in the same context five verses earlier and one chapter later? And why is it any less likely that the author of II Chronicles considered the destruction of Seir by the Moabites (who have a wellattested sacral herem; see below, at the end of this section) a "cosmic" herem war, or that the author of the apocalypse in Daniel 11 saw Antiochus' campaign as a herem, even if the Hellenistic king himself did not? (Cf. Isaiah 34:1-8, cited immediately below, which may also be an apocalypse concerning foreign powers, and which is the most explicit description of a sacral war herem.) The prophet Isaiah considers the Assyrians God's agents (Isaiah 10:5-11); why then is it is impossible that the author of Rabshaqeh's speech in II Kings 19:11 and Isaiah 37:11 has him describe his campaign as a herem? The fact that in some of these verses the verb החרים is found alongside other verbs of destruction in no way indicates that התרים means mere destruction, as Stern maintains.

${ }^{15}$ For arguments against a late date for any or all of Joshua 6, see Stern 1991:140145.

חיל 16, translated "wealth," can also mean army (so LXX; see Stern 1991:201), and if so Micah attests not only to the herem of property, but to the herem of persons as well. Another passage from this period refers specifically to enemies destroyed in wartime as an offering to God (Isaiah 30:33, which, incidentally, seems to indicate that Isaiah did not object to the Tophet cult; see below, section 6). Cf. also II Kings 23:20, which, of course, is later. There is no reason to suppose that Micah 4:13 is post-exilic as suggested by many scholars; if the verse is in fact inspired by Canaanite myth (see Bordreuil cited by Stern 1991:201-203), a pre-exilic date is far more plausible. 
God himself renders Israel herem according to Jeremiah 25:9 (sixth century B.C.E.):

I am going to send for all the peoples of the north - declares the Lord - and for my servant, King Nebuchadnezzar of Babylon, and bring them against this land and its inhabitants, and against all those nations round about. I will cause them to be herem and make them a desolation...

Even in this passage it would seem that the meaning remains "offering to God;" God sends for Nebuchadrezzar and bids him offer Israel up as a herem. ${ }^{17}$ Similarly, God calls upon Babylon's enemies to make Babylon a herem in Jeremiah $50: 21,26 ; 51: 3$, verses usually ascribed to the end of the sixth century. ${ }^{18}$

In late-sixth-century prophecy, the verb החרים and the noun herem are used to refer to destruction by God himself (Zechariah 14:11, Malachi 3:24). ${ }^{19}$ However, even when God himself is the agent of destruction, the sacral character remains central to the notion of herem: God slaughters the victim of the herem as a meal for himself. In fact, the clearest expression of the herem of destruction as a sacrificial divine meal is Isaiah 34:1-8, a passage variously attributed either to deutero-Isaiah (a sixthcentury prophet) or to an apocalyptic visionary of the Second Temple period, in which God himself is the slaughterer: ${ }^{20}$

Approach, $O$ nations, and listen, give heed, $O$ peoples! Let the earth and those in it hear; the world, and what it brings forth. For the Lord is angry at the nations, furious at all their host; he has made them herem, consigned them to slaughter...For my sword shall be drunk in the sky; lo, it shall come down upon Edom, upon the people of my herem, to wreak judgment. The Lord has a sword, it is sated with blood, it is gorged with fat - the blood of lambs and hegoats, the kidney fat of rams. For the Lord holds a sacrifice in Bozrah, a great slaughter in the land of Edom. Wild oxen shall fall with them, young bulls with mighty steers; and their land shall be drunk with blood, their soil shall be saturated with fat. For it is the Lord's day of retribution, the year of vindication for Zion's cause.

\footnotetext{
${ }^{17}$ See Stern 1991:197-199.

${ }^{18}$ See note 14 above.

${ }^{19}$ See Stern 1991:204-207. Cf. also Isaiah 43:28, which, however, may be corrupt. Note that in Arabic חר, "sacred," is the opposite of חל,, "profane," while in Isaiah 43:28 the two words are found in synonymous parallelism.

${ }^{20}$ Pace Stern 1991:191, whose argument is unclear to me. If herem is a votive offering, and if God himself is executing a sacral herem in this passage (both premises accepted by Stern), then it follows that God is, in effect, making an offering to himself; i.e., preparing his own meal. Cf. Niditch 1993:40, who makes a similar argument against Stern, but even she is for some reason unsure whether God is the one who eats the herem meal in this passage.
} 
In this passage "the Lord holds a sacrifice;" he slaughters the nations as an offering to himself. This is, of course, a metaphor for wartime destruction. The fact that the herem is often mandated by God or even metaphorically carried out by God in no way vitiates its status as an "offering."

In fact, it would seem that in all biblical verses but one, ${ }^{21}$ herem is used in one sense and one sense only: a herem is a communal dedication to God. It differs from a neder in that a neder is a personal vow of dedication, made from private property, while a herem is communal property set aside for God: these can be either spoils of war, or people and property condemned by the authorities, sometimes metaphorically said to be "sacrificed" by God himself. Human beings or livestock devoted to God under these circumstances are slaughtered as an offering, albeit usually without the trappings of an altar and temple. Gold, silver, and other precious objects are placed in the Temple treasury. Cities are destroyed, and their sites are sacred and off-limits.

This sense of the word herem is attested in other Semitic languages as well. In the inscription of Mesha, the ninth-century Moabite king, the king describes his campaign against Israel: ${ }^{22}$

And Chemosh [the god of Moab] said to me, "Go, take Nebo from Israel!" So I went by night and fought against it from the break of dawn until noon, taking it and slaying all, seven thousand men, boys, women, girls and maidservants, for I had made them herem for Ashtar-Chemosh. (lines 14-17)

Similarly, in Nabatean, Old South Arabic, and Arabic, sacred precincts are referred to as haram and muharram; ${ }^{23}$ these are presumably public property set aside for the divine service. In these languages, however, the meaning has come to be extended to all types of sacred and forbidden things. Hence in Arabic, the women's quarters are declared harim, ${ }^{24}$ even though the twin elements of community and sanctity are missing, and in Nabatean, family (i.e. private) burial sites are declared herem to various gods, and therefore off-limits to non-family members. ${ }^{25}$ In this usage the element of sanctity is present, but the element of community is missing.

\footnotetext{
${ }^{21}$ Leviticus 27:28a, on which see below, section 5 .

${ }^{22}$ See Stern 1991:19-56, and literature cited there.

${ }^{23}$ See lexicon citations in note 9 above.

${ }^{24}$ But harim, "harem, women's quarters," a word which also means "wife" (cf. also hurma, "woman, wife"), may instead be related to hirmah/haramah, "sexual desire," which may ultimately be a reflex of the root ערם (see above, note 1).

${ }^{25}$ See citations in Hoftijzer and Jongleing 1995:405.
} 


\section{[3] The Herem in Pre-Deuteronomic Law and Narrative}

The use of the term herem to refer to a communal vow is common to the three major corpora of biblical law and narrative: pre-deuteronomic literature, deuteronomic literature, and priestly literature. However, the exact nature of the herem and the laws governing its execution are slightly different in each of these corpora.

In pre-deuteronomic law and narrative the herem is mentioned both in the context of war and in the context of the campaign against idolatry. Most of the haramim of the conquest narratives in Joshua and Judges, as well as the Amalek herem of I Samuel 15, stem from the predeuteronomistic layers of these books. ${ }^{26}$ Two important features are common to these haramim: (1) they involve not only the wholesale slaughter of persons, but also the destruction of the cities of the conquered peoples, ${ }^{27}$ and usually of their livestock ${ }^{28}$ and possessions as well (with the exception of gold, silver, and other precious items, which are deposited in the Temple treasury ${ }^{29}$ ); (2) the herem is contagious - the spoils devoted as herem render those who come in contact with them herem, with the result that they, their families, and their livestock must be put to death as an offering to God, and their other property destroyed or devoted as well. ${ }^{30}$ It would seem that these two issues are related:

${ }^{26}$ The only exception is Joshua 10 and 11, on which see Stern 1991:157-160; Weinfeld 1993:131-155, 167-170.

${ }^{27}$ See Joshua 6:24, 8:28 (where, however, the spoils are not herem); Judges 1:17, and cf. also Numbers 21:3. Cf. also the burning of Hazor in Joshua 11:11, which is usually considered Deuteronomistic, but which may reflect an older tradition (which Joshua 11:13 seeks to "excuse" in light of the Deuteronomistic view of the herem).

${ }^{28}$ Samuel and Saul in I Samuel 15 differed only on the precise terms of the herem: Saul wished to sacrifice the more beautiful livestock as an altar offering (see Milgrom 1990:430). Note that Samuel does not protest about the fact that Agag was kept alive (I Samuel 15:14, 19), but only about the livestock; Milgrom believes that he may have believed that Saul intended to slay him publicly later, as Samuel himself does in verse 33. Stern's assertion that Saul only claimed to have saved the livestock for sacrifice (1991:173-174) is more far-reaching than the accusation of Samuel himself, who does not deny that Saul meant to sacrifice the livestock (vv. 22-23). Nonetheless, it should be noted that Saul's herem is less stringent than Samuel's; the altar sacrifices are זבחים that are to be eaten by the people. Cf. Numbers 18:14, which allots the meat of the herem offerings to the priests (see below, section 5).

29 See Joshua 6:19, and below in this section.

${ }^{30}$ See Joshua 7:24-25, and below in this section. For the concept of sancta contagion in the priestly code, see Milgrom 1981:278-310, Milgrom 1991:443-456, and section 5 below. Stern 1991:149, 224-225, plays down the notion of the herem contagion, noting that Joshua and his messengers are not afraid to touch the proscribed objects in 7:23-24. However, they are authorized to burn the herem, and therefore their role is analogous to that of the priests in the sancta contagion 
because the herem is highly contagious, the cities and possessions of the conquered people, having come into contact with the herem people, must be destroyed, in order to prevent the herem from spreading further. Since the city itself is declared herem, even the land on which the burnt city stood is rendered a תל עולם, "an everlasting ruin," never to be rebuilt or cultivated. Joshua lays a curse upon whomever rebuilds Jericho (6:26), but this curse is only meant to reinforce a prohibition already extant, as is evident from the parallel description of the Ai (Joshua 8:28). ${ }^{31}$

The only mention of herem in pre-deuteronomic literature outside of the context of war $^{32}$ is Exodus 22:19: "Whoever sacrifices to a god shall be made herem, other than to the Lord alone." From this brief ${ }^{33}$ law it is difficult to ascertain precisely what the herem involved. It would seem that this early source ascribed a measure of sanctity to the foreign god; $; 4$ the idolater thus contracts herem sanctity from his idolatrous offering, and therefore he, too, must be ritually immolated in a herem. According to some scholars, the idolater's family and possessions are also condemned under the herem. ${ }^{35}$ However, this is not mentioned explicitly in the verse. Perhaps Exodus 22:19 envisions an idolater caught in the act and hauled immediately before a court, before he had time to go home and impart the contagion he contracted to his family and possessions. Numbers $25: 1-5$ provides an example of the pre-deuteronomic herem

of the priestly code, for whom the contagion does not prove lethal (the predeuteronomic material does not have a hereditary priesthood). The herem was clearly contagious; otherwise, Achan's family and possessions would not have been destroyed. See also Joshua 6:18, which clearly indicates that the herem is contagious even in cases of unintentional trespass.

${ }^{31} \mathrm{Cf}$. the destruction of Hazor in Joshua 11:11. In Joshua 11:13 Hazor is contrasted with other cities that are עמדים על תלם, literally, "standing on their hill/ruin."

${ }^{32}$ The herem against Jabesh Gilead (Judges 21:11) is a war herem against fellow Israelites, which has been reinterpreted in light of the Second Temple pact herem by the addition of verse 5 . See below, section 6 .

${ }^{33}$ The construction (literally "whoever sacrifices to [a] god shall be made herem, but to the Lord alone") is a bit awkward, and the Samaritan Pentateuch has a different reading (see summary of scholarship in Stern 1991:123-125). Niditch (1993:56) is uncomfortable with this verse; in her view the pre-deuteronomic literature knew of the herem only as "God's portion" and not as a punitive measure ("God's justice"). Niditich is forced to adopt A. Alt's proposal to substitute יחרם for in this verse; in her view, the editor who substituted יחרם was influenced by Deuteronomy. But Alt's proposal seems arbitrary, and it would seem that this verse is solid proof that even pre-deuteronomic sources knew of the herem as "God's justice" (although the primary reason for the herem in this verse is not justice, but the sancta contagion imparted to the worshipper by the foreign god). It is this verse that engendered the Deuteronomic conception, rather than the reverse.

34See von Rad 1962 (volume 1):210; Weinfeld 1993:118.

${ }^{35}$ Schmitt, cited in Lohfink 1986:194. 
against idolaters. Although the term herem is not used here, the victims are put to death publicly "for the Lord," immediately following their act of idolatry (verse 4$){ }^{36}$

We noted above that the only property under the herem that is not to be destroyed is gold, silver, and other precious items, which are instead deposited in the Temple treasury. The classic example of this is of course the herem of Jericho, against which Achan committed trespass. After describing the herem as it affects man and beast, and the herem contagion, Joshua says, "All the silver and gold and objects of copper and iron are consecrated to the Lord; they must go into the treasury of the Lord" (Joshua 6:19). What was done with this gold and silver once it was deposited into the Temple treasury? If the herem is indeed contagious, it would make no sense if this property were to be sold, and the proceeds used to purchase animals for sacrifice and to fund the maintenance of the Temple. The gold and silver themselves are contagious, and this contagion would not be removed simply because the gold was sold. ${ }^{37}$ Indeed, we have evidence that according to pre-deuteronomic sources the gold and silver in the Temple treasury were not sold in order to fund the Temple budget, but was stored in the Temple treasury. From the fact that the contents of the Temple treasury are frequently given by the kings of Judah to foreign powers as bribes, ${ }^{38} \mathrm{M}$. Haran infers that the gold and silver of the Temple treasury were held in reserve. ${ }^{39}$ Some of the herem gold and silver may have been used to make the gold and silver vessels used in the Temple service: according to II Kings 12:14, the funds collected for the repair of the Temple were not used for this purpose, perhaps because the gold and silver in the herem treasury were sufficient. ${ }^{40}$ It may be that the use of herem metals for this purpose was considered preferable to the use of the collected funds, because the use of

${ }^{36} \mathrm{Cf}$. also II Samuel 21:6.

${ }^{37} \mathrm{Cf}$. the priestly law of Leviticus 27 , according to which regular votive offerings may be redeemed or sold, but haramim cannot. See below, section 5 .

${ }^{38}$ See I Kings 15:18; II Kings 12:19, 16:8; 18:14-15.

${ }^{39}$ Haran 1978:285.

${ }^{40}$ Some explain that the donated silver was diverted from making vessels (its usual use) to finance the repair of the Temple itself (Gray 1964:187; Haran 1978:284). But it is hard to believe that normally silver donated to the Temple was cast into vessels either for use, as argued by Gray, or before being stored in the Temple treasury, as argued by Haran. How many vessels did the Temple need? Rather, it would seem that the Temple repair work itself involved making new vessels. II Kings 12:14 takes special note of the fact that the silver collected was not used for this purpose; the metals in the herem treasury were recast into the new vessels, and the silver collected was used to pay the workmen or purchase other materials. 
private donations would lead to an unseemly system of patronage: the Temple belongs to God, and not to any individual donor. ${ }^{41}$

This pre-deuteronomic evidence that the contagious gold and silver in the Temple treasury was held in reserve or used for sacred purposes, rather that sold to finance the Temple budget, dovetails nicely with the priestly account in Numbers 17:1-5, according to which copper used for illicit cultic purposes was nonetheless considered sacred, and thus it had to be melted down and used to form a plating for the altar. The sacred copper must itself be used in the divine service; it cannot, like other Temple property, be used to finance the Temple budget. ${ }^{42}$

Gold and silver under herem can legitimately be found only within the sacred precincts, and only authorized personnel can come into contact with it. Thus in Joshua 7, Achan, who steals metal objects from the herem, contracts contagion, as do his family and property, among whom and which the objects are stored. All of Israel is ultimately threatened, since Achan, his family, and property will ultimately come into contact with other Israelites and the herem will spread. Contagion is the reason that Achan is condemned; he and his family are themselves herem and must be ritually immolated. Their death is not a punishment for trespass against sacred property. ${ }^{43}$

\section{[4] The Herem in Deuteronomy}

The herem in Deuteronomy does not significantly differ from the herem of the pre-deuteronomic texts. Herem is mentioned in Deuteronomy in the same two contexts as in the pre-deuteronomic

\footnotetext{
${ }^{41}$ But note that in the parallel account in II Chronicles 24:14 the silver collected for the renovation project was cast into vessels. This is because Chronicles reflects the view of the priestly school, according to which the metals of the war herem are the personal possession of the priests. See below, section 5 .

${ }^{42}$ Metals used in foreign cults are not sacred according to the priestly school; see previous note, and section 5 below. Nonetheless, the copper censers used by Korah's men in the service of the Lord must be put to sacred use even according to P.

43Josephus (Antiquities V, 1), Philo (De Specialibus Legibus III, 83), and Rabbi Judah the Patriarch (Tosefta Zevahim 12:17) all believe that intentional trespass with regard to any temple property is a capital crime. But the Sages, who differ with Rabbi Judah the Patriarch in Tosefta Zevahim, maintaining that trespass is a simple negative commandment punishable by flogging, apparently understood the uniqueness of the herem contagion. The fact that intentional trespass against non-herem temple property is not punishable by death does, however, seem anomalous: the ruling regarding illicit use of temple property should certainly not be more lenient than the ruling regarding entering the Temple, where the death penalty is called for (Numbers 18:7). However, since there is no scriptural verse that calls for the death sentence in the case of trespass, Mishnah Sanhedrin 9:6 indicates that "zealots" may kill the violator without trial.
} 
literature: war and the campaign against idolatry. However, while in the pre-deuteronomic literature the herem is presented as an ad hoc decision to devote certain conquered cities to God, in Deuteronomy the Israelites are commanded to put all seven nations of Canaan under the herem. This change in conception engendered the reworking of the conquest narratives of Joshua by Deuteronomistic editors. ${ }^{44}$

Deuteronomy presents the reason for this blanket herem decree as follows (Deuteronomy 20:17-18; cf. Deuteronomy 7):

(17) You must make them herem - the Hittites and the Amorites, the Canaanites and the Perizzites, the Hivites and the Jebusites - as the Lord your God has commanded you, (18) lest they lead you into doing all the abhorrent things that they have done for their gods and you stand guilty before the Lord your God.

One of the well-known characteristics of the Deuteronomic source of the Pentateuch is its tendency to provide social rationales for laws which were originally cultic or magical in nature. ${ }^{45}$ The herem contagion, like other pre-deuteronomic legal concepts, is also developed in this manner in Deuteronomy. ${ }^{46}$ What was originally a cultic contagion rooted in the sanctity of the foreign cult becomes a social contagion, a safeguard against the possibility that the idolaters will influence the worshippers of the Lord. The war herem is not a mere communal vow to please the Lord; it is an extension of the herem against idolaters, which has been reinterpreted as a safeguard against idolatrous influence. The Deuteronomic source has thus created a single herem from the predeuteronomic wartime herem and the pre-deuteronomic idolatry herem: both are designed to prevent the spread of idol worship. There is thus no longer any reason to distinguish between certain Canaanite cities and others: all Canaanites are idolaters, hence they all must be put under the herem. Their idols are also, needless to say, to be considered herem (Deuteronomy 7:25-26):

(25) You shall consign the images of their gods to the fire; you shall not covet the silver and gold on them and keep it for yourselves, lest you be ensnared thereby; for that is abhorrent to the Lord your God. (26) You must not bring an abhorrent thing into your house, or you will be herem like it; you must reject it as abominable and abhorrent, for it is herem.

In the above passage, herem, which actually means sacred, is understood to mean abominable and abhorrent, because sacred to idolatry. This reflects the Deuteronomic reinterpretation of the herem of idolatry and its

\footnotetext{
${ }^{44}$ See Greenberg 1971; Weinfeld 1993:84-98.

${ }^{45}$ See Weinfeld 1972:190-243.

${ }^{46}$ See Greenberg 1971:348-350.
} 
contagion. However, it is clear that even Deuteronomy ascribes sanctity to the objects consigned to herem, for in Deuteronomy 13:17-18 the herem is referred to as "a holocaust to the Lord your God."47

The herem contagion is thus retained in Deuteronomy. However, the other salient feature of the war herem in the pre-deuteronomic literature, the wholesale destruction of the cities of the Canaanites, is not mentioned in Deuteronomy. In fact, Deuteronomy 6:10-12, which refers to God's bequest to the Israelites of "great and flourishing cities which you did not build, houses full of all good things which you did not fill, hewn cisterns which you did not hew, vineyards and olive groves which you did not plant," seems to suggest that the Canaanite herem did not involve the destruction of property other than cult objects according to Deuteronomy. ${ }^{48}$ This makes sense. In the pre-deuteronomic literature select cities were made herem in their entirety. Deuteronomy, which applies the herem to all the Canaanite cities across the board, could hardly retain the totality of the herem, since this would involve a conquest without any booty whatsoever, with all urban sites rendered "everlasting ruins," never to be rebuilt. Moreover, since the contagion is reinterpreted as a social rather than cultic matter, it is not strictly necessary to destroy property; it is the people and the idols that are the bad influences. ${ }^{49}$

${ }^{47} \mathrm{Niditch}$, for whom the salient feature of the deuteronomic herem is divine justice, rather than offering, is nonetheless compelled to admit that Deuteronomy 13:17 is "the most literal reference to the ban as sacrifice" (Niditch 1993:63).

For other examples of sanctity taboo in Deuteronomy, see 22:9 and 23:18, which, however, use the root rather than the root word תועבה to describe the sancta of the Egyptians (Exodus 8:22), which the Egyptians therefore avoided (Genesis 43:32, 46:34); these verses may have led to the Roman (mis)conception that the prohibition of pork, which is described as a תועבה (see Plutarch, Moralia 669e-671c).

Of course, one must distinguish between the notion that the idols are inherently sacred, and the notion that the pyre in which the idols are destroyed is sacred because it is an offering to God. Nonetheless, the language of Deuteronomy 7:26 seems to indicate that the idols have a certain inherent sanctity (note that the same word דבק "stick," used here in connection with the idolatry taboo, is used in Deuteronomy to refer to man's relationship with God, e.g. 4:4, 13:5). Cf. Stern 1991:115, who, however, apparently does not believe that the herem on idolatry in Deuteronomy is a sanctum תועבה.

${ }^{48}$ See Greenberg 1971:345. Note that this does not really contradict the predeuteronomic notion. In the pre-deuteronomistic material the herem is an actual vow, and therefore conquered persons, livestock, gold, silver, and the city itself may be devoted, but they need not be (cf. Joshua 8:28), depending upon the terms of the vow. However, since the herem of the Canaanites often involved the destruction of the city and its contents in the pre-deuteronomic material, Deuteronomy's laxity in this regard requires explanation.

${ }^{49}$ So Greenberg, 1971:345. 
Canaanite cities are thus not condemned to total destruction in Deuteronomy in the context of the conquest because this is impractical. Nonetheless, where practical, Deuteronomy does retain the total herem as a safeguard against contagion, reflecting the older tradition. We have seen above that in the pre-deuteronomic literature, the war herem usually involves total destruction of property, while in the idolatry herem, if there is no reason to believe that the herem has spread to property, property is probably spared, as are the family members of the idolater. ${ }^{50}$ In Deuteronomy the exact opposite is the case. The war herem, as we have seen, is not applied to booty for practical reasons: the herem has been reinterpreted as a safeguard against the spread of idolatry, rather than a true contagion. However, the Israelite idolatry herem is still understood in its sacral context, and thus it renders the property of the inhabitants of an idolatrous Israelite city herem (Deuteronomy 13:13-18):

(13) If you hear it said, of one of the towns that the Lord your God is giving you to dwell in, (14) that some scoundrels from among you have gone and subverted the inhabitants of their town, saying "Come let us worship other gods...." (16) Put the inhabitants of that town to the sword. Make it, and its cattle, and all that is in it herem: (17) gather all its spoil into the open square, and burn the town and all its spoil as a holocaust to the Lord your God. And it shall remain an everlasting ruin, never to be rebuilt. (18) Let nothing of the herem stick to your hand....

This does not necessarily contradict the ruling of Exodus 22:19 and Numbers 25:4, which do not mention the destruction of property. The pre-deuteronomic verses referred to individual idolaters caught in the act, before they had a chance to impart their contagion to family and property. Since the reference in Deuteronomy is to a city all of whose inhabitants were idolaters, the contagion has already spread, and must be strictly contained.

\section{[5] The Herem in the Priestly Literature}

The term herem is not used in the narratives of the priestly source of the Pentateuch. Moreover, it would seem that the earlier priestly traditions, which developed independently of the non-priestly traditions, ${ }^{51}$ did not know of the herem at all. Thus idolatry in the priestly legal material is forbidden (Leviticus 19:4, 26:1), but does not engender herem contagion and is not necessarily even punishable by death. ${ }^{52}$ Phineas' zealous slaying of Zimri (Numbers 25:7) had as much to do

\footnotetext{
${ }^{50}$ See above, section 3.

${ }^{51}$ See Frankel 1994:5.

${ }^{52}$ The only exception is Moloch worship: Leviticus 20:2.
} 
with his public carnal act as with his worship of Peor, which is not even mentioned specifically as an act of Zimri. Sacrificing to demons is considered more of a cultic nuisance than anything else, to be remedied by a ban on slaughter outside the sacred precincts. ${ }^{53}$

The priestly narrative material has an institution parallel to the war herem, but very different from it. A proportion of the livestock spoils of the war against Midian are deemed "a levy for the Lord" (Numbers 31:28), but this is given to the priests and Levites as their personal property (Numbers $31: 29,30,41,47$ ), since they "attend to the duties of the Lord's tabernacle." An additional contribution to the Lord of gold was deposited in the Tabernacle as a reminder on behalf of the Israelites before the Lord (Numbers 31:54). This distinction between livestock and gold is reminiscent of the earlier material, but the livestock is given to the priests and Levites, and not immolated for the Lord, while the deposit of gold is a reminder, akin to the jar of manna (Exodus 16:33-34) and Aaron's rod (Numbers 17:25), and not a treasury to be replenished with the spoils of war on a regular basis. It is one-time-only token, presumably not to be used at all..$^{54}$

It is possible that this account is a polemic against the notion of herem and the waste that it entailed. Yes, argue the priests, it is important to devote some of the spoils of war to God, but these should be given to the priests and Levites, rather than immolated. And if some of the spoils of war do find their way into the Temple itself, and not into the hands of the priests, it should be clear that these are token contributions. There is no need for a Temple treasury consisting of "contagious" metals despoiled in war.

We have noted above that priestly narratives do not use the term herem to refer to devoted spoils of war or to the fate of idolaters. However, the term herem is used in priestly legal material: it is found four times in Leviticus 27, once in Numbers 18, and once in Ezekiel's priestly law code. Leviticus 27:21 refers to one who dedicated a field by means of a neder, and then the field was sold:

When it is released in the Jubilee, the land shall be holy to the Lord, like herem land; it becomes the priest's holding.

The law of the herem itself is found in Leviticus 27:28-29:

\footnotetext{
${ }^{53}$ See Leviticus 17:7.

${ }^{54}$ Or perhaps, as suggested to me by David Frankel, it was melted down and used in the construction or repair of the Temple furnishings. Cf. the use of the term "reminder before the Lord" in Exodus 30:16 to refer to silver collected for use in making sockets for the sanctuary (see Exodus 38:25-28), and the use of the term "reminder" in Numbers 17:5 to refer to the copper plating of the altar.
} 
(28a) But no herem, be it man or livestock or land of a man's holding, nothing that a man has made herem may be sold or redeemed. (28b) Every herem is totally consecrated (םשיש מדש Lord. (29) No human being who is made herem can be ransomed: he shall be put to death.

Numbers 18 lists the herem among the various sacred offerings that belong to the priest:

(12) All the best of the new oil, wine, and grain - the choice parts that they present to the Lord - I give to you. (13) The first fruits of everything in their land...shall be yours; everyone of your household who is clean may eat them. (14) Every herem in Israel shall be yours. (15) The first issue of the womb of every being, man or beast, that is offered to the Lord, shall be yours....

A similar list is found in Ezekiel 44:29-30:

(29) The meal offerings, sin offerings, and guilt offerings shall be consumed by them. Every herem in Israel shall be theirs. (30) All the choice first fruits of every kind, and all the gifts...shall go to the priests.

These verses present a number of difficulties. They are not all of one cloth. Leviticus 27:28a uses the term herem in a different sense than we have seen hitherto; it is not a communal vow at all, but a personal donation to the Temple, identical to the neder except in that it is unredeemable. It would seem that this half-verse is a later addition to Leviticus 27, for the following reasons:

(1) As it stands, Leviticus 27:28 consists of two sentences, each of which begins with the words כל חרם, and both of which state the same idea: that the sanctity of the herem is absolute and irrevocable. The two half-verses are doublets, and it would seem that the more explicit of the two, 28a, was added in order to interpret the less explicit 28b.

(2) The juxtaposition of Leviticus 27:28 with Leviticus 27:29 creates an ethical crux: the implication is that a man can devote his slave as herem, whereupon the slave is immolated as an offering to God. Commentators and scholars from the Rabbis on have interpreted verse 29 in various other ways, ${ }^{55}$ but all of these ignore the immediate context of the previous verse. If, however, we consider Leviticus 27:28a a later addition, Leviticus 27:28b-29 can be seen as a recapitulation of the law of the pre-deuteronomic war herem: the spoils of war devoted as herem are contagious (קדש קרשים), and therefore human beings who are dedicated as herem, or those who come into contact with haramim, must be put to death.

55See below, section 6; Rashi, Nahmanides, ad loc.; Stern 1991:131-133. 
Leviticus 27:28b blatantly contradicts both Leviticus 27:21 and Numbers 18:14. In all other priestly laws in the Pentateuch pדש קדשים means contagious sanctity. "Totally consecrated" sancta impart holiness to all who come into contact with them. If those who come into contact are ritually clean priests who are found within the Temple precincts, nothing happens; if they are lay or unclean people, the contagion proves lethal. ${ }^{56}$ Since the herem is described in both the pre-deuteronomic and Deuteronomic literature as contagious, and since usually means contagion, any other interpretation of p p in Leviticus 27:28b is out of the question. ${ }^{57}$ This verse clearly restates the contagious nature of the pre-deuteronomic and deuteronomic haramim in priestly terms. However, according to Leviticus 27:21, herem land is the personal possession of the priest. One can hardly imagine a contagious field counted among the personal possessions of a priest, yet off-limits to his wife and daughters, and to all farmhands who are not ritually pure priests..$^{58}$ Moreover, the produce of the field would presumably also be herem and therefore not marketable. ${ }^{59}$

Numbers 18:14 also indicates that haramim are the personal possessions of the priests, and thus not contagious. As J. Milgrom has pointed out, this verse lists the herem among the non-contagious sancta given to the priests (Numbers 18:11-19), rather than among the contagious קדשי קדשים (Numbers 18:9-10). ${ }^{60}$ However, Ezekiel 44:29, which is parallel to Numbers $18: 14$, lists the herem along with the contagious sancta; non-contagious sancta are listed in the next verse. ${ }^{61}$

56Milgrom 1991:443-456.

${ }^{57}$ Pace Milgrom 1976:53, note 187, and 66, note 235; Milgrom 1990:428-429; Milgrom 1991:182-183. It is true that Ezekiel accords the status of pשרשים to the entire Temple complex (43:12), and the entire territory of the priests (48:12); however, it would seem that is best understood as a utopian ideal (Levenson 1976:143), rather than as a different usage of the term pas maintained by Milgrom 1991:321).

${ }^{58} \mathrm{Cf}$. Milgrom 1990:152, who maintains that the herem is not contagious in the priestly source, and yet for some reason posits that herem lands and unclean animals were put to use for the Sanctuary, a view that is not consonant with Leviticus 27:21, or with Milgrom's own view as stated elsewhere (1976:53, note 187; 1990:429).

${ }^{59}$ Milgrom 1990:152 says that "the grain harvested from herem lands comprises the grain offerings on the altar" (again, not in consonance with Leviticus 27:21 or with Milgrom 1976:53, note 187). But even if this were correct, a tiny plot would suffice to provide all the grain necessary for the public grain offerings; there simply are not that many of them.

60Milgrom 1990:429.

${ }^{61}$ The designation pמדש קרשים is not used here, but the distinction between the sancta of verse 29 and those of verse 30 is obvious. Stern's claim (1991:126) that Ezekiel $44: 29$ is clearly a conflation of Numbers $18: 9$ and 14 is absurd; by the 
It would seem that two distinct priestly rulings existed with regard to the herem of the other Pentateuchal sources: communal property dedicated to God in war, and possibly also the ritual immolation of idolaters. Leviticus 27:28b-29 considered the herem to be קרש קרשים, contagious, as did the non-priestly sources. Humans, both those consigned to the herem in wartime, and those who contract the herem by touching haramim, are to be immolated (Leviticus 27:29); livestock is presumably to be sacrificed and treated as paten by the priests, like the sin and guilt offerings, and like the meal offering (Ezekiel 44:29). Gold and other precious metals are not mentioned, and presumably even this layer of the priestly source, although clearly influenced by nonpriestly material, does not recognize the herem status of metals deposited in the Temple treasury. ${ }^{62}$

What of the ruins of the herem cities, considered nלי עולם, "everlasting ruins," by the pre-deuteronomic ${ }^{63}$ and deuteronomic ${ }^{64}$ sources? It stands to reason that these are the שדי החרם, the herem lands, of Leviticus 27:21.65 However, that verse is composite: the last three words לכהן תהיה אחוחו, "it becomes the priest's holding," are syntactically problematic, ${ }^{66}$ and are best considered a later gloss. It would make little sense if fields dedicated by neder were to be considered Temple property until the Jubilee, and the private property of the priests after the Jubilee. The original verse read "when it is released in the jubilee, the land shall be holy to the Lord, as the herem land." Land devoted permanently to the Lord is not merely the property of the Temple treasury. It attains the status of herem, the desolate land upon which the ruins of the herem cities once stood. This contagious land is not to be cultivated by the priests or anyone else.

This conception of the status of herem, however, conflicts with the attitude toward the spoils of war demonstrated elsewhere in the priestly

same token one might argue that Ezekiel 44:30 is a clear conflation of Numbers $18: 13,11$, and 19 and 15:20. Ezekiel devotes only two verses to the priestly gifts: the first verse lists contagious sancta, while the second lists non-contagious sancta. I see no reason to assume that this concise, well-organized list is dependent upon the parallel laws in Numbers 18 (but nor is the reverse necessarily true). Both codes are independent formulations of priestly traditions. See Haran 1979:63-66.

${ }^{62}$ It is therefore doubtful that the story of the renovation of the Temple in II Kings 12 , which alludes to the fact that herem metals were used to make the Temple vessels (12:14, see section 3 above) stems from a priestly source, as maintained by Gray 1964:583, inter alia. See above, note 41.

63Joshua 8:28.

${ }^{64}$ Deuteronomy 13:17.

${ }^{65} \mathrm{Cf}$. the first suggestion made by Stern 1991:129, which he then rejects.

${ }^{66}$ These words, taken literally, form an independent clause meaning "The priest's holding belongs to him," a tautology that has nothing to do with the herem lands. 
material in the Bible. Therefore, other priestly writers classified the herem as the personal possession of the priests, to be used by himself and his family (Numbers 18:14). This is in keeping with the priestly tradition regarding the levy for the Lord in Numbers 31.

A later priestly writer felt the need to reconcile these contradictory laws regarding the herem. He therefore added Leviticus 27:28a: "But no herem, be it man or livestock or land of a man's holding, nothing that a man has made herem may be sold or redeemed." This half-verse casts a new light on all the other references to herem in the priestly corpus. A herem is no longer a communal neder; it is an irredeemable personal neder. It is thus pot in the usual sense of contagion, but in a relative sense: it is holier than a mere neder in that it is irredeemable. ${ }^{67}$ If a human being, this type of herem must still be immolated (since there is no getting around the categorical law of Leviticus 27:29). ${ }^{68}$ But Numbers 18:14 and Ezekiel 44:29 are now understood to mean that herem livestock becomes the personal, non-contagious possession of the priest. The herem land of Leviticus 27:21 is no longer the eternal ruin of the herem city; it is now understood to refer to private land dedicated to the Temple in perpetuum. This, too, becomes the private property of the priest, as the late priestly writer made clear by adding the words "it becomes the priest's holding" to Leviticus 27:21.

The Rabbis were not inclined to accept this reinterpretation of Leviticus 27:28b. For them, קרש קדשים cannot possibly refer to the personal possession of the priests. They therefore maintained that the herem of Leviticus 27:28a and Numbers 18:14 differs from the herem of Leviticus $27: 28 \mathrm{~b}$, and these two haramim differ, in turn, from the herem of Leviticus 27:29. Tosefta Arakhin 4:34 reads as follows:

There are three types of haramim:

"But no herem, be it man or livestock or land of a man's holding, nothing that a man has made herem may be sold or redeemed"

(Leviticus 27:28a) - these are the haramim of the priests.

"Every herem is totally consecrated (קדשים) to the Lord"

(Leviticus 27:28b) - these are the haramim of heaven.

"No human being who is made herem can be ransomed: he shall be put to death" (Leviticus 27:29) - these are those who are sentenced to the death penalty in court.

According to this source, ${ }^{69}$ a herem can be designated either pדשים pרשים in which case it is used for Temple repairs, or the personal possession of

\footnotetext{
${ }^{67}$ See above, note 57.

${ }^{68}$ For the circumstances under which persons are made herem according to this late gloss on the priestly law, see below, section 6 .

${ }^{69}$ Another interpretation is found in BT Arakhin 29a: the herem is pשדש putil it is physically transferred to the Temple, at which point it becomes the personal
} 
the priests, depending upon the intention of the donor. ${ }^{70}$ We have evidence that this interpretation was actually put into practice during the Second Temple period. The copper scroll discovered at Qumran lists certain caches of treasure as herem. The reference is clearly to Temple property, and not to the personal possessions of the priests; if these haramim were personal property of the priests, there would be no need to store them in separate caches. ${ }^{71}$

\section{[6] The Herem of Persons in Second Temple Literature}

Let us return now to the herem of persons. We have seen that according to Leviticus 27:28-29 in its current form, the herem of persons is a personal dedicatory vow, under the terms of which the dedicated person is consigned to death. This is the result of the juxtaposition of the supplementary verse 28 a with verse 29 , which originally referred to the war herem and those affected by the herem contagion. But how did the editor who added Leviticus 27:28a envision the dedicatory herem of persons? Since the herem of persons is mentioned along with the herem of land and beasts, ${ }^{72}$ it would seem that the reference is to the sacrifice of a dependent of the votary: a family member or slave. ${ }^{73}$

Human sacrifice per se is not categorically outlawed by the priestly code. Ezekiel, the prophet of the priestly school, specifically states that God commanded human sacrifice at some point in order to punish Israel $(20: 26),{ }^{74}$ he castigates the Israelites for sacrificing their children to idols instead of to God (16:20). ${ }^{75}$ Leviticus 18:21 and Leviticus 20:2-6 likewise outlaw human sacrifice to Moloch only, and Moloch is clearly

property of the priests. For other rabbinic explanations, see Rashi and Nahmanides to Leviticus 27:28-29.

${ }^{70}$ See Mishnah Arakhin 8:6, Mishnah Nedarim 2:4 and Tosefta Nedarim 1:6 for cases in which the type of herem is not specified, and see next note.

${ }^{71}$ The fact that the Qumran caches are in Judea may indicate that the version of Tosefta Nedarim 1:6 found in the manuscripts, "Unspecified haramin are permitted (for common use, i.e. they are considered personal property of the priest) in the Galilee," is correct; in Judea the haramim were usually placed in the Temple treasury, because of its proximity, while in Galilee the local priests took possession of them. Lieberman 1967:411 prefers the reading in the printed editions, "Unspecified haramin are forbidden in the Galilee, and permitted in Judea," which agrees with Mishnah Nedarim 2:4 and the baraita as cited in BT Nedarim $19 \mathrm{~b}$, but this may be a secondary reading designed to harmonize the various sources.

72Note also that the term מכל אשר לו, "of his holding," in Leviticus 27:28a refers to man, beast, and land. However, the reference is not necessarily to a slave; children were also said to belong to their father. Cf. Numbers 16:32.

73Levine 1989:199; Stern 1991:134 (under desperate circumstances only!).

${ }^{74}$ See Greenberg 1983:368-370.

75. See Greenberg 1983:281, 293. 
understood by Leviticus 20:5 to be a foreign god. ${ }^{76}$ Pre-deuteronomic sources clearly do not condemn the sacrifice of humans to the Lord at all; Jephthah's sacrifice of his daughter is not in any way condemned in Judges 11, and Genesis 22 does not outlaw human sacrifice per se; on the contrary, Abraham is considered a paragon of virtue because of his willingness to sacrifice his son. ${ }^{77}$ It is only Deuteronomy 12:30-31 and Deuteronomy 18:10 that specifically outlaw human sacrifice whether to the Lord or to other gods. ${ }^{78}$

It would seem, however, that the consent of the offering is required; otherwise, the sacrifice is murder. This is indicated by Judges 11:36, in which Jephthah's daughter expresses her willingness to be sacrificed. ${ }^{79}$

The consent of the offering can also legitimize the sacrifice of humans other than the children or slaves of the offerer. This is implied in Judges 21:1-14, a source that is key to understanding the herem of

${ }^{76}$ I follow the general consensus that these verses refer to child sacrifice (pace Weinfeld 1972, who argues that the reference is to ritual dedication by non-lethal passing through fire) to a god named Moloch (pace Eissfeldt 1935, who argues that Moloch is a type of sacrifice to the Lord).

${ }^{77}$ An earlier layer of Genesis 22 may have had Abraham actually sacrifice his son. The story as it stands presents a mixed message: it is certainly not a polemic against child sacrifice, since God himself orders such sacrifice and Abraham is blessed for obeying; nor is it a perfect test of Abraham's faith, since he does not actually have to go through with the deed. It reads as something of a cruel joke played by God, a fact which led later authors to attribute the idea to Satan (see Jubilees 17:16). The story would make much more sense if it actually involved a perfect test of Abraham's faith, demanded by God and carried out (see also Niditch 1993:44-46).

As the Rabbis have noted (see Spiegel 1969, Ibn Ezra to verse 18), Abraham returns alone at the end of the story (verse 19). Moreover, the angel says explicitly in verse 16 that Abraham has "done this deed," and "not spared" his son, phrases that cannot easily be explained in their present context. The double call of the angel (verses 11 and 15) is unnecessary in the present version of the story: verse 16 is a doublet of verse $12 \mathrm{~b}$. The angel could have uttered his blessing immediately after calling upon Abraham to stay his hand. All of this evidence points to an original version of the story consisting of all or most of verses 1-9; a modified version of verse 10 , viz. "And Abraham picked up the knife and slayed his son and offered him up as a burnt offering," and verses 15-19 without the word ("a second time") in verse 15.

${ }^{78}$ The only exceptions to the deuteronomic prohibition of human sacrifice are the communal haramim (the herem of the Canaanites and the herem of the idolatrous city), for which see above, section 4.

${ }^{79}$ While there is no specific indication in Genesis 22 that Isaac consented to be sacrificed, neither is there any mention of objection on his part. It would seem that verses 7 and 8 are meant as a poignant, artistic portrayal of Isaac's realization that he is the intended victim and his consent, as the Rabbis have noted (see Genesis Rabbah 56:4; Rashi to verse 8). 
persons. This story follows immediately upon a tale of civil war between the tribe of Benjamin and the rest of the Israelites:

(1) Now the men of Israel had taken an oath at Mizpah: "None of us will give his daughter in marriage to a Benjaminite." (2) The people came to Bethel and sat there before God until evening. They wailed and wept bitterly, (3) and they said "O Lord God of Israel, why has this happened in Israel, that one tribe must now be missing from Israel?" (4) Early the next day the people built an altar there, and they brought burnt offerings and offerings of well-being. (5) The Israelites asked, "Is there anyone from all the tribes of Israel who failed to come up to the assembly before the Lord?" For a solemn oath had been taken concerning anyone who did not go up to the Lord at Mizpah: "He shall be put to death." (6) The Israelites now relented toward their kinsmen the Benjaminites, and they said, "This day one tribe has been cut off from Israel! (7) What can we do to provide wives for those who are left, seeing that we have sworn by the Lord not to give any of our daughters to them in marriage?" (8) They inquired, "Is there anyone from the tribes of Israel who did not go up to the Lord at Mizpah?" Now no one from Jabesh Gilead had come to the camp, to the assembly. (9) For, when the roll of the troops was taken, not one of the inhabitants of Jabesh Gilead was present. (10) So the assemblage dispatched 12,000 of the warriors, instructing them as follows: "Go and put the inhabitants of Jabesh Gilead to the sword, women and children included. (11) This is what you are to do: Make every man and every woman who has known a man carnally herem." (12) They found among the inhabitants of Jabesh Gilead 400 maidens who had not known a man carnally...(13) Then the whole community sent word to Benjamin...(14)...and they gave them the girls who had been spared from the women of Jabesh Gilead....

Who swore the oath in verse 5 ? The oath would be pointless if it were sworn by those already assembled to fight the Benjaminites at Mizpah; apparently the Israelites, including the men of Jabesh Gilead, were adjured by those who summoned them to the meeting at Mizpah. ${ }^{80}$ The lives of the people of Jabesh Gilead were forfeit as herem because they bound themselves by oath on penalty of death, along with the rest of the Israelites, to join in the battle against the Benjaminites at Mizpah. A person can thus make himself herem, offering himself in sacrifice to God, by swearing to submit to sacred immolation if he violates his oath.

Many scholars believe that this story is loosely based upon Numbers 31 , the story of the massacre of the Midianites by the Israelites, and therefore dates shortly after the redaction of the priestly code during the

${ }^{80}$ Judges 19:30 implies that the emissaries of the Levite summoned the Israelites to the meeting at Mizpah. Our verse indicates that this summons was accompanied by an adjuration. 
Persian period. ${ }^{81}$ This would coincide precisely with our conjecture regarding the date of Leviticus $27: 28 \mathrm{a}$, which is a supplement to the redacted priestly code. ${ }^{82}$ However, another school of thought sees the story as a polemic against Saul, the Benjaminites, and their allies in Jabesh Gilead (see I Samuel 11:5-10; 31:11-13), in which case the story would date from the beginning of the Davidic dynasty. ${ }^{83}$ This argument is quite convincing. Nonetheless, it is possible that those elements reminiscent of the total war in Numbers 31, as well as other minor details, are later additions from the Persian period. Verse 5 would seem to be one of the later additions. The verse is clearly a doublet of verse 8 . Without this verse, the war against Jabesh Gilead is simply a secondary flare-up between the Israelites who fought in the main war and a tribe that did not join in the main war, a recurrent motif in the book of Judges, ${ }^{84}$ and the herem of verse 11 is simply the usual war herem. However, the use of the herem against fellow Israelites (a plot device needed to free up the orphan maidens for marriage to the Benjaminites ${ }^{85}$ ) was very disturbing to a post-exilic editor, who added verse 5 in order to establish that the people of Jabesh Gilead brought this fate upon their own heads by swearing, in a communal oath, that they will participate in a herem against shirkers, and submit to a herem if they do not attend the rally at Mizpah. ${ }^{86}$

This is not the only occurrence of this type of herem in Second Temple literature. I Enoch 6:1-6, written in Aramaic probably not long after Leviticus 27:28a and Judges 21:5, ${ }^{87}$ reads as follows:

(1) In those days, when the children of man had multiplied, it happened that there were born unto them handsome and beautiful daughters. (2) And the Watchers, the children of heaven, saw them

\footnotetext{
${ }^{81}$ See literature cited by Amit 1992:288, note 1.

${ }^{82}$ In accordance with the view held by most scholars, that the priestly code was redacted during the Persian period.

${ }^{83}$ This position seems to now be the majority view. See Amit 1992:292-293. Amit herself adopts a compromise position: she accepts the later dating, but regards the story as part of a polemic between Judahites and Benjaminites during the Persian period (Amit 1992:321-324).

${ }^{84}$ See Judges $5: 16-17,23 ; 8: 1-3 ; 12: 1-6$.

${ }^{85}$ See Stern 1991:162-163.

${ }^{86}$ See above, note 80 . Niditch (1993:69-72) detects in the story a possible critique of the herem ideology.

${ }^{87}$ According to Milik 1976:128, I Enoch 6-17 actually predates Genesis 6:1-4 and the priestly redaction of the Pentateuch. The earliest manuscript evidence, however, dates from the third or second century B.C.E. (Milik 1976:5; Stone 1991:256). At any rate, the Book of Watchers (I Enoch 1-36) predates Jubilees and Ben Sira, and according to Stone (1991:190) it is "a precursor of the Qumran type of Judaism." Stone does not rule out the possibility that the book dates from the Persian period.
} 
and desired them; and they said to one another, "Let us go and choose wives for ourselves from among the daughters of man and beget us children." (3) And Shemihaza, who was their leader, said unto them, "I fear that perhaps you will not consent that this deed should be done, and I alone will become responsible for this great sin." (4) But they all responded to him, "Let us all swear an oath and make one another herem not to abandon this suggestion but to do the deed." (5) Then they all swore together and made one another herem. (6) And they were altogether two hundred who descended in the days of Jared onto the summit of Hermon. And they called the mountain Hermon, for they swore and made one another herem.

Joseph's brothers are said to have made a similar pact according to the Testament of Zebulun 1:6: "I was afraid of my brothers because they had all agreed that, if any one disclosed the secret [of the sale of Joseph], he should be killed by the sword." 88 While the word anathema, the Greek equivalent of herem, is not used here, the agreement between Joseph's brothers is strikingly similar to the herem of the fallen angels in I Enoch. Moreover, the brothers' pact is actually termed a herem in an eighthcentury midrash. ${ }^{89}$ Since the word herem is not used in quite this sense in post-talmudic literature, it stands to reason that the use of the word reflects an older tradition.

In the Damascus Document (CDC IX,1), Leviticus 27:29 is interpreted as follows: "And that which [Scripture] states: 'Any herem ${ }^{90}$ that a man makes herem from among mankind shall be put to death by means of the laws of the gentiles." Given the fact that the herem could not be carried out by the sect itself under the political conditions in which they found themselves, the Qumran community suggests that the מוחרם be handed over to the authorities on a trumped up charge, ${ }^{91}$ so that the authorities will put him to death in accordance with their laws. The reference can hardly be to a slave sacrificed by a member of the Qumran community. Since the enactments of the community often took the form of communal oaths, ${ }^{92}$ and since the passage in I Enoch cited above was found at

${ }^{88} \mathrm{Cf}$. Testament of Naphtali 7:4.

${ }^{89}$ Pirke deRabbi Eliezer Chapter 38; Tanhuma Vayeshev. See below, section 9.

${ }^{90}$ Emending חרז with E. Qimron in Broshi 1992:27, note 1. The Genizah manuscript does not contain the words "And that which [Scripture] states" at the beginning of this sentence, but the Qumran manuscripts do, and therefore what follows must be a citation from a biblical verse. The only plausible candidate is Leviticus 27:28a, which begins with the words כל תרם.

${ }^{91}$ The reference is probably to the Hasmonean authorities, whose laws are termed "gentile" by the members of the sect because of Hellenistic influences. See below, note 127.

${ }^{92}$ Members of the sect took oaths to uphold communal regulations upon their initiation (Manual of Discipline V, 8-10; CDC XV, 5) and were adjured to come 
Qumran, it is likely that the reference is to a communal enactment agreed to under herem. ${ }^{93}$ The community member who violates the herem is to be handed over to the authorities on a trumped up charge, and "offered up to God" by means of his civil execution.

Another pact-type herem is mentioned in Acts 23:12-14:

(12) When it was day, the Jews made a plot and made themselves anathema neither to eat nor drink till they had killed Paul. (13) There were more than forty who made this conspiracy. (14) And they went to the chief priests and elders, and said, "We have anathematized ourselves with an anathema to taste no food till we have killed Paul."

The word anathema is often translated "curse." 94 But the word means "votive offering" in classical Greek..$^{95}$ In the Septuagint, it is used as the standard translation of the Hebrew word herem, and according to the explanation that we offered above, the reference is to a communal votive offering of people, animals, precious items, cities, and land, usually in the context of warfare. The Septuagint's use of the word anathema thus merely reflects the correct understanding of the biblical herem as a

forth with information about criminal activity (CDC IX, 10-12), a striking parallel to one of the uses of the excommunication herem in Geonic times (see Schiffman 1983:111-132). Cf. also the Ein Gedi oath and other parallels cited by Weinfeld 1986:58-64, in which members of a group adjured one another to secrecy.

${ }^{93}$ See below, section 8 . Similar interpretations have been suggested by A. DupontSommer and others (see references in Winter 1967:132-133, note 6). For other interpretations see Rabin 1958:44, Yadin 1983 (volume 1):382, Winter 1967:131136, Rabinowitz 1967:433-435, Falk 1967:569, Derret 1983:409-415; and Schiffman 1983:10 and 20, note 16. Most of these scholars contend that the passage condemns the מזרים to death by means of the Gentile courts, because he condemned another to death. But this is impossible, in view of the biblical verse upon which this law is explicitly based. The sect could hardly condemn someone to death for invoking the biblical herem, and then maintain that this is an interpretation of the biblical herem itself! Schiffman 1983:20, note 16, argues that the Qumran law may be based upon Genesis 9:6 (which sentences the murderer to death), but apart from the use of the word $ם$ (s, I cannot see any relationship between the two. At any rate, the words "And that which [Scripture] states" require a direct citation, and only Leviticus 27:28a can be intended. Leviticus 27:28-29 condemn the מוזרים to death, and not the

${ }^{94}$ See Behm 1964:364-365; Kuhn 1990:80-81.

${ }^{95}$ The usual spelling in classical Greek is anathema with eta following the theta, while the Hellenistic spelling is usually anathema, with epsilon (see Moulton and Milligan 1930:33). But this does not reflect a difference in meaning: anathema with epsilon is used for "offering" in the LXX, Plutarch, and Philo, while anathema with eta is used in the Hellenistic sense (for which see immediately below) in a curse tablet from Amathous. For detailed references, see Pardee 1995:158-163. 
dedicatory vow. ${ }^{96}$ The New Testament and early Christian usage of the word anathema is also precisely analogous to the various forms of herem that developed in post-Biblical Hebrew and Aramaic. ${ }^{97}$ In this case, the analogy is to the Second Temple herem described above. The conspirators invoked a herem, vowing one another as herem if they shirk their communal responsibility by partaking of food before Paul is killed. ${ }^{98}$

In all of the above passages, we have merely surmised that the herem involved death as a sort of ritual immolation or sacrifice, on the basis of the meaning of herem in the Bible. However, this is nearly explicit in another New Testament passage, Mark 14:71 // Matthew 26:74, which tells of Peter's denial of Jesus. The text in Mark reads as follows:

But he began to make himself anathema and swear, "I do not know this man of whom you speak."

The usual explanation is that Peter strengthened his oath by invoking a curse upon himself in the event that his words prove false. ${ }^{99}$ But as we have seen above in Chapter One, 100 the words "swear" and "oath" themselves refer to a curse invoked upon the swearer in the event that he is lying; anathema, on the other hand, means "offering," not "curse."101 The anathema must refer to something more specific: Peter makes a votive

\footnotetext{
${ }^{96}$ Those who translate "curse" do not consider the semantic development of the word in Hellenistic Greek anomalous. They consider the biblical war herem to be a type of curse, condemning the victim to death. See Behm 1964:354; Kuhn 1990:80-81; Pardee 1995:162-163. But as we have seen above (sections 2, 3 and 4), the biblical herem is a consecration, not a curse.

${ }^{97}$ In later Christian literature, anathema comes to mean excommunication from the Church (see note 135 below), in a development analogous to the development of the Jewish concept of herem in the amoraic period (see section 6 below). For other New Testament passages, see immediately below, and below, section 9 . In two non-Jewish curse texts, the word anathema is attested as a curse (see Pardee 1995:159-161 and note 9 there). These texts are probably influenced by Jewish magical texts (Kuhn 1990:81; Pardee 1995:161). This does not prove that the word anathema means curse; to declare someone herem or anathema is, of course, a curse, since he is doomed to death, but that does not mean that the word itself is a word for "curse." Moreover, votive terminology is often used as curse terminology in Aramaic Jewish magic spells and formulae, because the demons are adjured and bidden to make themselves herem and bidden to make a neder to carry out their magic (see below, Chapter 7). The word herem itself is attested in a Jewish Aramaic magic bowl from Babylonia (Naveh-Shaked 1993:128-129).

${ }^{98} \mathrm{Cf}$. Saul's adjuration of the Israelites not to eat until they have defeated their enemies in I Samuel 14:24. This adjuration is termed a herem (and recast as a Geonic herem of excommunication) in Pirke deRabbi Eliezer Chapter 38/ / Tanhuma Vayeshev. See below, section 9.

${ }^{99}$ See commentaries, ad loc.

${ }^{100}$ See above, Chapter 1 , section 1 , and below Chapter 5 , section 1.

${ }^{101}$ See above, note 97.
} 
offering of his own life to God in the event that he is lying. And indeed, this is precisely what he promised Jesus he would do in Mark 14:30-31 (// Matthew 26:34-35):

(30) And Jesus said to him, "Truly, I say to you, this very night, before the cock crows, you will deny me three times." (31) But he said vehemently, "If I must die with you, I will not deny you...."

When he denies Jesus, his life is thus forfeit "with Jesus;" like Jesus, Peter takes it upon himself to die as a human sacrifice. ${ }^{102}$

Most of the Second Temple sources that refer to the herem of persons thus indicate that it is a conditional vow made by a group of conspirators to ritually immolate anyone in the group who does not follow through with the group's plan. It was also possible to declare oneself herem in the event that one is lying. Since these sources, like Leviticus 27:28a, date from Second Temple times, it may be that the herem of persons envisioned by the author of Leviticus 27:28a is akin to this type of herem; the swearer agrees to forfeit his own life or that of his dependents (מכל אשר לו) if he fails to carry out the terms of a pact. At any rate, it is clear from the sources cited above that the herem of persons as practiced or envisioned during the Second Temple period differed significantly from the war and idolatry haramim of persons: the sacrificial victim was neither an enemy nor an idolater, but an Israelite who agreed to forfeit his own life, either in the context of a pact or oath, or at the request of the head of his household, who vowed him as herem.

\section{[7] Herem as a Ban on Social Intercourse}

Chronologically speaking, the next clearly attested usage of the word herem is in the Mishnah, where the word is used as a prohibitive vow formula. As we have seen above, ${ }^{103}$ however, these references are difficult to interpret and classify. Some of them seem to presuppose another meaning of the word herem, "excommunication," a meaning clearly attested only in amoraic sources. ${ }^{104}$ We shall therefore deviate for the moment from chronology and study the use of the term herem in the sense of "excommunication" and the related, post-talmudic, sense of "communal enactment," and then return to the tannaitic allusions to herem as a prohibitive vow formula.

We have seen above that herem is used in the sense of excommunication only in the Late Aramaic dialects of Syriac, Palestinian

\footnotetext{
102 Jesus' death is in fact reminiscent of the Qumran herem, in which the "offering" is handed over to the gentile authorities for execution.

${ }^{103}$ See above, section 1 .

${ }^{104}$ Primarily PT Moed Qatan 3:1, 81 c-d; BT Moed Qatan 16a-17b. See immediately below.
} 
Christian and Jewish Aramaic, Mandaic, and Babylonian Jewish Aramaic. It is also attested in Babylonian amoraic Hebrew and later Hebrew, but the Hebrew use is clearly based upon the Aramaic. ${ }^{105}$ This can hardly be seen as a development of the biblical Hebrew herem. ${ }^{106}$ Even in Deuteronomy, where the votive element is not so apparent, the herem is not a curse, but a type of offering to God.107 The excommunication herem has been considered ${ }^{108}$ an outgrowth of Ezra's decree "that anyone who did not come within three days would, by decision of the officers and elders, have his property made herem (יחרטי) and himself excluded (יבדל) from the congregation of the returning exiles" (Ezra 10:8). However, in Ezra the excommunication is specifically not referred to with the term herem: the property is made herem and presumably given to the priests or the Temple; ${ }^{109}$ the people themselves are "excluded (יבדל) from the congregation of the exiles," but not by means of a herem. 110

Given that the meaning excommunication is attested only in Late Aramaic, it would be most logical to seek an Akkadian etymology for the usage, since Akkadian influences on Aramaic are well-attested. ${ }^{111}$ Haramu is attested in Akkadian lexical texts as a synonym for parasu, "to cut, divide, separate."112 This meaning is clearly relevant to the notion of excommunication. It is probably not related at all to the root $\pi^{113}$ it most likely derives from a'n, "to cut," the root that Driver sought to connect with the war herem, ${ }^{114}$ and which is reflected in the biblical Hebrew word תרום, "slit, mutilated."115

${ }^{105}$ In Mishnaic Hebrew, the word for excommunication is נדונ. See below in this section.

${ }^{106}$ See $A r u c h$, s.v. חרם, which connects the biblical and amoraic uses. Kohut (Aruch Hashalem, ad loc.) apparently derived both from $\pi$, but Krauss in the Tosefet Ha aruch corrects חרם The also biblical lexica, which invariably cite the Aramaic usage as cognate with the biblical 1 ; Behm 1964:354; Pardee 1995:169.

${ }^{107}$ See above, sections 3 and 4 , and note 96 .

${ }^{108}$ See Malamat 1961:149; Cohn 1971:344.

${ }^{109}$ Yohoram should not be translated "confiscated;" this sense is modern Hebrew only. See Lieberman and Kutscher 1963:38.

${ }^{110}$ In the New Testament excommunication from the synagogue or church is never referred to as anathema. See below, note 135 .

${ }^{111}$ See Kaufman 1974.

${ }^{112} \mathrm{CAD}, \mathrm{H}, 89-90$.

${ }^{113}$ Pace Stern 1991:8-9, citing Brekelmans; Levine 1974:129. While Akkadian h is occasionally a reflex of proto-Semitic $\pi, \pi$ usually becomes $e$ in Akkadian. In this case, since parasu means almost exactly the same thing as Semitic 4 'ri, a connection with would seem to be out of the question.

${ }^{114}$ See above, section 2 .

${ }^{115}$ The use of haramu and the root 0 ' $\pi$ in Akkadian is anomalous, quite like the Aramaic use of חרם in the sense of excommunication. In addition to the verb 
Herem is clearly attested with the meaning "excommunication" only in amoraic texts. ${ }^{116}$ The mishnaic Hebrew word for excommunication is נדוי (from the verb נרה (17). 117 In the Palestinian Talmud the Aramaic verb אתרם In the Babylonian Talmud the words herem and החרים are used in both Hebrew and Aramaic with the sense "excommunication," and an artificial distinction is made between נדוי and herem, the former being a less severe, preliminary stage in a process which leads up to the latter. ${ }^{119}$ In Babylonia, excommunication was used as a punitive device and a means of enforcement in the Jewish court system, and it therefore became a formal, multi-tiered process. ${ }^{120}$ In Palestine, on the other hand, excommunication was an informal, extra-legal device used by the Patriarchate and later by Rabbis outside the court system. ${ }^{121}$

Analysis of the Palestinian usage of the Aramaic root however, that a distinction should be made between herem and נרוי in PT

haramu II (=parasu) discussed above, haramu I is the Old Babylonian and Old Assyrian spelling of neo-Babylonian aramu/eremu, "to cover, to place a tablet in a clay envelope," for which von Soden lists no cognates in other Semitic languages (but cf. ערם, "to pile up," in Hebrew, Aramaic and Arabic; Akkadian arammu, "dam, ramp"). Harimtu means prostitute, and scholars have suggested that this is evidence that haramu II (=parasu) is cognate with Semitic $ם$ ח, because the word harimtu comes to mean prostitute in the sense of either "social outcast" (cf. the Aramaic herem), "cloistered one" (cf. Arabic harim, "women's quarters") or sacred prostitute (related to חר in the sense of holy, as qedeshah is related to Hebrew (קד). However, this cannot be the case, because the masculine form harmu, "lover," is used to describe the gods Tammuz and Apsu, the lovers of Ishtar and Tiamat respectively. No sense of prostitution, cultic or otherwise, cloistering, taboo, or social denigration can possibly be imputed to these relationships. Perhaps harmu and harimtu are related to Arabic ע'רם, "to obligate, love," or Arabic haramah/hirmah, "sexual desire" (which, in turn, may derive from ערם via Syriac, see note 1 above).

${ }^{116}$ But see below, section 9 .

${ }^{117}$ Finkelstein 1962:78 believes that נדוי during the late Second Temple and tannaitic periods did not denote ostracism from the Jewish community as a whole, but only from the חבורה (the community of Pharasaic who were stringent with regard to ritual purity). Leibson 1975:298-299, 319 and 1979-80:188, note 64, argues cogently that tannaitic involved primarily expulsion from the house of study. Cohn 1971:350, on the other hand, argues against Finkelstein on the basis of sources that describe tannaitic נדוני all late amoraic accounts, which no doubt recast the tannaitic in accordance with their own practice. See also below, note 123 .

118 See Leibson 1979-80:185, note 50.

${ }^{119}$ See BT Moed Qatan 16a and other references cited by Cohn 1971:350-351.

${ }^{120}$ See Leibson 1975:340-342.

${ }^{121}$ See Leibson 1975:298-321. According to Leibson 1975:314-316, lay people could also impose a herem in Palestine during the amoraic period. But see immediately below. 
as well. In tannaitic literature, Iדוי refers to the ostracism of a scholar or communal leader by the Patriarchate or the Rabbis. ${ }^{122} \mathrm{He}$ was banished from the house of study, and it was forbidden to study with him. ${ }^{123}$ The Aramaic root $\pi$, on the other hand, is used only in the following three examples in PT Moed Qatan 3:1, 81d:

Rabbi Joshua ben Levi summoned a certain man three times, but he did not come. He [Rabbi Joshua ben Levi] said: "If not for the fact that I have never made anyone herem (חרמית) in my life, I would have made herem (מחרם) that man..."

One of Bar Pata's maidservants passed by a synagogue and saw a teacher beating one of his pupils more than was necessary. She said, "Let that man be מחררם..."

Rabbi Simeon ben Laqish was guarding fig trees in Barbarit. Thieves came at night to steal some figs. Eventually he noticed them and said, "Let these people be מוחרמין." They said, "Let this man be מוחרם...."

All three of these cases are considered מרוי, or "excommunication," in the ensuing talmudic discussions in Hebrew; in some cases the ensuing

122 See Leibson 1975:298-314.

נדוי 123 See Leibson 1979-80:186-190. However, tannaitic sources record threats made against the non-rabbinic figures Onias the Circle Drawer (Mishnah Taanit 3:8) and Thaddeus of Rome (PT Moed Qatan 3:1, 81d). If tannaitic (and pretannaitic) נדוי consisted of banishment from scholarly circles, as argued by Leibson and Finkelstein (see note 117 above), how could נדור have been threatened against non-rabbinic figures? Bokser 1987:125 has demonstrated on the basis of parallels that the threat of נדוי is a secondary addition in the Thaddeus story on the basis of the Onias story. As far as Onias himself is concerned, the story takes place during Temple times, and according to Mishnah Middot 2:2 the מנודה had to enter the Temple court through a side entrance, while Mishnah Eduyot 2:2 indicates that he was barred from the Temple court entirely. These rulings may very well be retrojections of the tannaitic practice barring the מuדה from the house of study; the tannaim simply assumed that contemporary practice regarding the house of study was based on Temple practice. The sanction of נדוי threatened against Onias would thus be exclusion from the Temple court. For another view, see Green 1979:638, who argues on the basis of the that the Mishnah has recast Onias as a rabbinic figure (as did the Babylonian Talmud, Taanit 23a, which refers to Onias entering the house of study and answering questions clearly). However, there is no real evidence of this in the Mishnah, and Sarfatti 1957:143 has demonstrated that the reference in BT Taanit 23a is a reworking of a Palestinian tradition that originally referred to the Temple. Nonetheless, it is clear that the Rabbis based their description in Mishnah Taanit 3:8 of the relationship between the rival communal leaders, the charismatic Onias and the scholarly Shimon ben Shetah, on the relationships between their contemporaries in the house of study and the Sanhedrin. 
discussion is presented as part of the original story. ${ }^{124}$ However, only the first could possibly be interpreted as excommunication in the classical sense the word. According to the ensuing talmudic discussion, examples two and three indicate that even maidservants and thieves have the authority to declare someone "excommunicated," if they deserve excommunication. But it is hardly likely that either the maidservant or the thieves expected all of Israel to ostracize the "excommunicants." It would seem that the references here were originally to a type of personal excommunication, a vow binding upon the excommunicant forbidding him from making contact with the votary. The maidservant may have called upon her master and other parents to "boycott" the teacher, while Resh Laqish and the thieves may have excommunicated one another from the fellowship of thieves, since Resh Laqish is reported to have been a thief himself, who maintained his relationship with gangs of thieves even after becoming a scholar. ${ }^{125}$ Although in the examples cited the root חר is used in this sense in Aramaic only, it would seem that this personal ban is the type of herem described in the Hebrew text of Mishnah Nedarim 5:4:

[If one says] "I am herem to you," the one mentioned in the vow is forbidden [to derive benefit from the votary's property].

[If he says] "You are herem to me," the votary is forbidden [to derive benefit from the property of the one mentioned in the vow].

[If he says] "I to you and you to me," both are forbidden [to derive benefit from one another]. Both are permitted to derive benefit from property declared public by those who came up from Babylonia [during the Restoration following the Babylonian exile], but are forbidden to derive benefit from municipal property [which is considered owned in partnership by the residents of the town, including the מוזרמין].

Such a vow thus has drastic consequences, even if it does not involve total ostracism. The מוחרם is forbidden to derive benefit from municipal services. It would seem that the vow formulae מופרשני ממך, "I am separated from you," and מנודה אני לך, "I am excommunicated from you" (Mishnah Nedarim 1:1), were also used in this type of vow.

The Aramaic herem was thus codified and "hebraized" by the Rabbis in Mishnah Nedarim 5:4. But the concept of personal herem is attested as early as the first century C.E. In Romans 9:3 Paul declares that he is so committed to his brethren that for their sake he would even be willing to "wish himself an anathema from Christ." The usual, erroneous

\footnotetext{
${ }^{124}$ The stories as cited are in Aramaic in the original. What follows immediately after each story is mostly in Hebrew, which would indicate that it is part of an editorial layer, and not an original part of the story.

${ }^{125}$ See BT Bava Metsia 84a; PT Terumot 8:10, 46b.
} 
interpretation of anathema as "curse" makes no sense here, and thus translators are forced to render "accursed and cut off from Christ" or the like. However, if we render herem in the sense found in Mishnah Nedarim 5:4, the meaning is clear: Paul is willing to declare himself herem to Christ, and therefore prohibited from having contact with him or deriving benefit from him.

How did the root herem come to refer specifically to this type of personal ban? We have already seen that haramu in Akkadian means to "cut off," and this meaning, which ultimately derives from the protoSemitic root ח'רם (which is not connected with Hebrew and Aramaic dialects in the sense of "excommunicate." However, it is hard to believe that the institution of personal herem derives directly from the Akkadian, since this institution is nowhere mentioned in Akkadian texts. It would seem that the herem of personal ban derives from the Second Temple herem of persons. We have seen that it became increasingly difficult to actually carry out the herem sanction against those who violate a herem agreement; the Qumran community resorted to libeling the "sacrifice" before the civil authorities, which was obviously not always practical. But even when the herem was not carried out, there was still a practical ramification of the herem that remained in effect: the sanctity of the מוחרם was contagious, and thus all contact with him must be avoided. It is easy to understand how the term herem then came to be used to refer to an obligation to avoid another person. The herem of excommunication thus derives from a combination of two factors: the Akkadian and Aramaic use of the root $\pi$ in the sense of "cut off," and the evolution of the Second Temple pact herem into a type of personal ban.

\section{[8] Excommunication at Qumran}

The Qumran texts shed further light on the development of the excommunication herem. We have already seen that CDC IX, 1 mandates the execution of the herem by means of the civil authorities, and we have proposed that the reference is to a person who has violated the communal agreements made binding by a Second-Temple-type pact herem. CDC XX, 1-3 seems to refer to the same issue:

And this is the regulation regarding any of those who join the men of holy perfection and then loathe to carry out the commands of the upright; he is the man who is "melted in the midst of the furnace."

The reference is to Ezekiel 22:19-22:

(19) Assuredly, thus said the Lord God: Because you have all become dross, I will gather you into Jerusalem. (20) As silver, copper, iron, lead and tin are gathered into a furnace to blow the 
fire upon them, so as to melt them, so will I gather you in my fierce anger and cast you and melt you. (21) I will gather you and I will blow upon you the fire of my fury, and you shall be melted in it. (22) As silver is melted in a furnace, so you shall be melted in it. And you shall know that I the Lord have poured out my fury upon you.

Clearly Ezekiel is referring to a type of death sentence by fire. The usual explanation is that the reference is to the gathering of the people of Judah into Jerusalem immediately prior to the destruction of the city by fire in 586 B.C.E. 126 the verses are thus reminiscent of some of the predeuteronomic and Deuteronomic examples of herem (Joshua 6:24, Deuteronomy 13:17).

According to the pesher on this verse in CDC XX, 1-3, the silver to be melted in the furnace is the renegade sect member. This melting is very likely identical to the denunciation of the מותרם to the gentiles in CDC IX, 1. The link between trial in a gentile court and melting in a furnace is found in 4QpPsa 2:18-20:

The interpretation [of Psalm 37:15] concerns the wicked of Ephraim and Manasseh who will attempt to lay hands upon the priest and the members of his council in the period of testing [=purifying in a crucible] which will come upon them. However, God will save them from their hands, and afterwards they will be delivered into the hands of the terrible gentiles for judgment.

The word "testing," מצרף, actually refers to the testing of impure metals in a furnace or crucible, precisely as in Ezekiel 22:19-22. In the "period of testing," עת מצרף, God will deliver the wicked into the hands of the terrible gentiles for judgment. Although the wicked in this case are not necessarily the renegade sectarians of CDC IX, 1 and CDC XX, 1-3, the motif of testing impure silver in the crucible of gentile justice in 4QpPsa indicates that the two CDC passages, one of which refers to testing impure silver and the other of which refers to trial by gentiles, are referring to the same thing. ${ }^{127}$

${ }^{126}$ See commentators, ad loc.

${ }^{127}$ In 4QpPsa the reference is either eschatological, in which case the judgment of the gentiles is the campaign of a foreign power (the ascending Roman power?) against those who will, at the end of days, persecute a future righteous Priest and the Qumran sectarians (so Allegro 1956:95), or else historical, in which case the reference is to the campaign of the Seleucids against those who persecuted the righteous teacher, the founder of the Qumran sect (so Stegemann 1963:261, note 145). In either case, the "judgment" is not an actual trial, but divine punishment by means of a foreign power. CDC IX, 1, on the other hand, requires an actual gentile judiciary to sentence the renegade sect member to death. What foreign judiciary could the author of CDC possibly have in mind? The reference cannot be to the Roman authorities. A post-Hasmonean dating for CDC as a whole, and 
Immediately after referring to the renegade as "the man who is melted in the midst of the furnace," however, CDC XX proceeds to mitigate his sentence considerably: "When his deeds become apparent, he shall be sent away from the congregation..." (CDC XX, 3-4). Moreover, according to CDC XX, 4-8, if the excommunicant is penitent, he is to be accepted back into the community. ${ }^{128}$ This passage has troubled many scholars, some of whom have proposed complex literary histories to explain the composition of CDC XX, 1-8, according to which the death sentence, permanent excommunication, and temporary excommunication are mandated by different layers of the text, which were added on top of one another as conditions in the Qumran community changed. ${ }^{129}$ L. Schiffman, on the other hand, has proposed that the entire passage mandates only temporary excommunication, and the renegade is not a renegade at all, but a sect member who has committed the relatively minor infraction of violating a sectarian ordinance derived from Scriptural exegesis, for which the Manual of Discipline also mandates only temporary excommunication (VIII,1619). .130

Neither explanation is quite satisfactory. The question of source criticism of CDC is beyond the scope of this work; however, the complex analyses of this passage do not seem warranted by the evidence. Schiffman's proposal is also problematic, since the harsh language suggests a more general and more serious offense; Schiffman is thus forced to characterize the reference to Ezekiel 22:22 as "parenthetical."

this passage in particular, is impossible, since 4QDa, one of the Qumran manuscripts of CDC (which contains IX, 1), dates from Hasmonean times. CDC as a work is usually dated to Hasmonean times, when the Palestinian judiciary and civil authority were Jewish. But there are those who assign a pre-Hasmonean date to some or all of CDC (see survey of scholarship in Davies 1983:14-47), and even if CDC as a whole dates from the Hasmonean period, it is possible that CDC IX, 1 is a citation of an older interpretation of Leviticus 27:28a (note that other laws in CDC IX would seem to predate the sectarian boycott of the Temple, usually dated to the beginning of Hasmonean rule). If so, the reference could be to the Seleucid royal court or to the judiciary in Jerusalem during the period of direct Seleucid rule under Bacchides (159-152 B.C.E.). Stegemann, in fact, believes that the founder of the Qumran community served as high priest during this period, which would provide an ideal background for the cooperation between ecclesiastical and civil authorities envisioned in CDC IX, 1. However, it is more probable that the reference is to the Hasmonean judiciary in Jerusalem, whose laws are termed "gentile" because they are subject to Hellenistic influences.

${ }^{128}$ The Manual of Discipline (VII, 22-25) mandates permanent expulsion under similar circumstances. See Schiffman 1983:170-171.

${ }^{129}$ See Murphy-O'Connor 1972:553-555; Pouilly 1975:532-538.

${ }^{130}$ Schiffman 1983:171. 
Two other possible explanations suggest themselves in light of our interpretation of CDC IX, 1 and CDC XX, 1-8:

(1) In a pre-literary stage, the herem death sentence may have been carried out against traitors and those who violate communal agreements by the members of the sect themselves. At a later stage, the herem was executed at first by giving the מוחרם over to the authorities on a trumped-up charge. This law was incorporated into CDC (IX, 1). When, however, even this proved impractical, it was replaced by excommunication, since if the מוחרם cannot be executed, he is still contagious. This stage is reflected in CDC XX, 1-8. The law opens with a statement that the excommunicant is indeed worthy of death by means of the crucible of the gentile courts. In practice, however, he is to be excommunicated until such time as he repents.

(2) Perhaps the reference to the testing of silver in a crucible in CDC XX, 3 is not a metaphor for destruction at all, but a type of ordeal. The renegade is handed over to the civil authorities on a trumped-up charge, as per CDC IX, 1 . The trial in the court of the gentiles is meant to serve as a crucible for the renegade "silver;" if he is unworthy, he will be killed by the authorities, but if he survives the process he has been purified, and may therefore, upon repentance, reenter the community. Until then he is contagious and מוחרם in the sense of excommunication.

\section{[9] Herem and Anathema}

The Mishnah and Tosefta contain numerous references to herem, and the New Testament contains a number of references to anathema. Some of these can be explained in light of one of the meanings discussed above: communal votive dedication, personal irredeemable votive offering, mutual dedication as human sacrifice in the case of violation of an agreement (or personal dedication of oneself in the same manner), personal ban, or excommunication. In Mishnah and Tosefta Arakhin, and in references in halakhic Midrashim and baraitot to herem in the context of Leviticus 27 and related biblical verses, the meaning is obviously "votive offering" of one sort or another. This meaning is found in Tosefta Nedarim 1:6 as well, and the word anathema is used in this sense in Luke 21:5.

The meaning "human sacrifice" in the context of a mutual dedicatory vow made by the members of a group is found, as we have seen, in I Enoch 6, in the Damascus Document, in Acts 23, and in traditions regarding the conspiracy of Joseph's brothers. We have found the anathema as a personal invocation of immolation upon oneself if one's oath is violated in Mark 14:71. 
It is possible that this meaning is attested in Mishnah Nedarim 1:1 as well. A person who makes a vow using the word herem (נדר בחרם) is compared there to a person who makes a vow using the word "nazirite" (נדר בנזיר); it is clear from Mishnah Nedarim 2:3 that a vow בנזיר is not a vow of naziriteship per se, but to a vow declaring the votary a nazirite if he breaks his word. The analogous vow בחרם would be a vow declaring the votary herem if he breaks his word, precisely the type of Second Temple herem we have encountered above.

This meaning may lie behind the use of the phrase נדר בחרם in Mishnah Nedarim 2:5 as well:

If one vows using the word herem [דר בחרם] and then says, "I only meant to vow by a fishnet [herem of the sea];" if one vows by gorban and says, "I only meant gifts [קרבנות] to kings;" if one says "I myself [עצמי] gom gorban" and then says, "I was referring to a bone [עמי] that I keep in order to vow with it...."

S. Lieberman explains that in the first two examples the reference is actually to oaths using the words herem and gorban, and not to vows. ${ }^{131}$ However, the fact that the first example, of herem, is cited along with the third example, "I myself am qorban," may indicate that the word herem in this mishnah refers to a personal vow of self-immolation used to strengthen an oath, similar to the anathema of Peter in Mark 14:71, or a vow of immolation in the context of a pact. Rabbi Meir, who insists that these vows be carried out, must however have understood that the sanction in such a case is excommunication, and not actual immolation.

However, a third attestation of the phrase נרר בחרם suggests that the phrase refers not to the Second Temple type of herem, under which persons are declared anathema, but to a vow likening a permitted object to an object that is herem for the priests or for the Temple, a mere variant on the rabbinic-type prohibitive qonam vow, discussed above in Chapter One. ${ }^{132}$ Tosefta Nedarim 5:3 reads as follows:

One who intended to vow using the word עולה ("burnt offering"), but instead used the word ("nazirite"), or [intended to vow] using the word qorban ("offering"), but instead used the word shevu'ah ("oath"), is not bound. But if he intended to use the word עולה ("burnt offering") and instead used the word qorban ("offering"), or if he intended to use the word herem but instead used the word ("consecrated property"), he is bound.

This text clearly indicates that a vow using the word herem is analogous to a vow using the word הדק ה permitted property to sacred property. Accordingly, we must surmise

${ }^{131}$ Lieberman 1942:128.

${ }^{132}$ Chapter 1 , section 1 . 
that when the Rabbis reinterpreted the Second Temple prohibitive vow as a vow likening hitherto permitted property to Temple property, they sanctioned the use of the word herem in this sense as well. ${ }^{133}$ This is also apparently the meaning of the vow כחר discussed in Mishnah Nedarim 2:4, which is mentioned alongside the similar vow formulae כמעטר and כתרומה, and therefore it may also be the concept that lies behind the phrase נדר בחר in Mishnah Nedarim 1:1 and Mishnah Nedarim 2:5. In this case, all of these texts should be interpreted as rabbinic type personal vows, in which the word herem takes the place of the word qorban or qonam. ${ }^{134}$

As we have seen, herem serves as a type of personal ban in Mishnah Nedarim 5:4, as well as in the examples of haramim in popular Aramaic usage in PT Moed Qatan. This is also the meaning, as we have seen, of the anathema in Romans 9:3. This meaning of anathema is found in two other New Testament passages: I Corinthians 16:22 and Galatians 1:8. These verses were once thought to refer to a formal type of excommunication from the Church; however, the consensus is now that this meaning of anathema is first attested in later Christian literature. ${ }^{135}$

${ }^{133}$ See above, Chapter 1 , sections 1 and 7 . Note however, that the herem is never attested as a prohibitive vow (or more precisely, as a dedicatory vow designed never to take effect, whose only practical ramification is a personal prohibition) in Second Temple literature. The only possible reference is the pun on the word herem in CDC XVI, 15 (see above, Chapter 1, section 5), which is not an example of usage, but a clever prooftext, in which herem is taken as a near-synonym for neder.

${ }^{134} \mathrm{Cf}$. also Midrash Tehillim 10, in which Korah speaks of a widow harassed by Aaron, who finally declares all of her property herem, whereupon Aaron takes it for himself. The word herem may have a double meaning here: the widow intends a prohibitive vow, but Aaron pretends that she means the priestly herem. Cf. also Genesis Rabbah 41, which describes a conversation between Rabbi Eliezer and his father Hyrcanus:

His father said to him, "I came up [to Jerusalem], my son, in order to disinherit you (לנרותך מנכסי, lit. "to bar you from my property by means of נגדו"), but now all of my property is given to you as a gift. He replied, "They are herem to me. I shall have an equal share with my brothers."

Note, however, that Hyrcanus also used the term לנדות, usually reserved for the excommunication of persons, in the sense of "disinherit;" Eliezer thus retorts by making the possessions herem from himself.

${ }^{135}$ See commentaries ad loc. and Behm 1964:354, cited by most of the more recent commentaries. The word anathema is first used to refer to excommunication from the church at the Council of Elvira in 306 C.E. (see Cross-Livingston 1974:50). In the New Testament, removal from the synagogue or church are mentioned frequently, but they are never termed anathema. Schuerer concludes from this that in the New Testament, as in BT, herem/anathema is more severe than יור, which is only temporary removal (Schuerer-Vermes-Millar 1973-1987 [volume 2]:431-432). But in fact, the opposite is the case. נדוי or removal implies expulsion from the 
This development of the Church anathema is analogous to the development of the Jewish herem; what was initially a personal ban was later understood as a synonym for public excommunication (נדוי) in PT, and as a severe form of excommunication in BT. ${ }^{136}$ In I Corinthians 16:22 Paul simply declares "him who does not love the Lord" anathema from himself. In Galatians 1:8, Paul, as a rhetorical device, declares the preacher of a different gospel, even if he be an angel or Paul himself, worthy of being made personally anathema by his audience. ${ }^{137}$

I Corinthians 12:2-3 is a well-known crux. Paul explains to the Corinthians that not everything said by Christian ecstatics is inspired by the Spirit of God:

(2) You know that when you were heathen you were led astray to dumb idols, however you may have been moved. (3) Therefore I want you to understand that no one speaking by the Spirit of God ever says "Anathema Jesus," and no one can say "Lord Jesus" except by the Holy Spirit.

The verse has long puzzled commentators and scholars; what Christian ecstatic would curse Jesus? It is often suggested that the reference is to certain Gnostics who cursed Jesus, the man, while worshipping Christ, the Lord. ${ }^{138}$ But as we have seen, anathema does not mean curse, and therefore this far-fetched interpretation is unnecessary. Anathema is used here in the sense of personal ban. Some of the ecstatics may have found the gifts of the spirit overpowering and painful, and therefore may have sought to drive Jesus away. ${ }^{139}$ Paul therefore states that anyone who tries to force Jesus to keep his distance by declaring Jesus herem to his own person is not actually speaking by the Spirit. ${ }^{140}$

Pharasaic חבורה, house of study, synagogue, or church (see above, note 117; John 9:22, 12:42, 16:2; I Corinthians Chapter 5). Herem/anathema, on the other hand, prohibits only one-on-one contact, though even this has ramifications regarding the community as a whole (see Mishnah Nedarim 5:4, discussed in section 6 above).

${ }^{136}$ See below.

${ }^{137}$ In this context, the meaning may be "put to death by means of a herem," the death sentence of the false prophet in Deuteronomy 13:6 being interpreted in light of the fate of the idolatrous city in Deuteronomy 13:16.

${ }^{138}$ See references in Conzelmann 1975:205, note 10(b); Kuhn 1990:81. See also the other interpretations in Conzelmann 1975:204-205, and Conzelmann's refutation of the gnostic theory.

${ }^{139}$ As Paul himself nearly does in Romans 9:3, though he uses a more elegant formulation, declaring himself willing to become anathema from Jesus rather than vice versa. Cf. also Jeremiah 20:9.

${ }^{140}$ Perhaps the question addressed to Paul by the Corinthians referred to a specific case, in which an ecstatic uttered over and over a chant that sounded like "anathema(r)anathema(r)anathema," but which he and/or some of his fellows interpreted as speaking in the Aramaic tongue: "anatha/maranatha/ 
As we have seen, herem comes to mean formal excommunication in amoraic ${ }^{141}$ and later Church ${ }^{142}$ usage. In PT herem is analogous to נדוי ,143 while in BT it is a more severe form of נדי ${ }^{144}$ The Babylonian herem was accompanied by a formal ceremony which made use of shofarot. ${ }^{145}$ In Geonic times, the word herem comes to refer to תקנות הקהל, communal legislation made binding by the sanction of formal excommunication. ${ }^{146}$ This usage harks back to Second Temple times, when a group would enforce a communal decision by means of herem. It would seem that the use of herem to refer to a communal decision is actually based on this Second Temple usage; the difference is that under the terms of the Second Temple herem each individual in the group made the others herem in the sense of sacrifice, while in Geonic times the communal leadership simply declared potential offenders herem, in the sense of excommunication. A midrash cited in the eighth-century works Pirke deRabbi Eliezer (Chapter 38) and Tanhuma (Vayeshev) actually recasts a number of examples of herem rooted in biblical and Second Temple literature - the herem conspiracy of Joseph's brothers mentioned in the Testament of Zebulun 1:6, the herem of Jericho (Joshua 6-7), Saul's adjuration of the Israelites not to eat (I Samuel 14:24), and Ezra's herem

maranatha/maranatha," "Our Lord, come; our Lord, come." The possibility of blasphemy led some of the church elders to insist that the practice of speaking in tongues be discontinued (cf. I Corinthians 14:39), and that only prophecy (i.e. orderly, rational discourse in Greek, or preaching) be permitted. Paul's responsum "concerning the pneumatics" (I Corinthians 12:1) opens by stating that church members are not infallible, since beforehand they were idolaters $(12: 2)$. He then proceeds with the truism that if in fact the ecstatic was ordering Jesus away with a herem, then he was not divinely inspired, but if he was calling Jesus Lord, he was divinely inspired (12:3). Paul then advocates a compromise position: Not everyone can preach, but the church needs all of its members, whatever their gifts: prophecy, faith, healing, miracle working, administration or speaking in tongues (12:4-31). There is nothing wrong with speaking in tongues, if it is accompanied by love (Chapter 13). But prophecy is clearly superior to speaking in tongues (14:1-25), and therefore speaking in tongues should be regulated, interpreted, and given low priority as compared with prophecy, although not outlawed (14:25-40). Paul then closes the epistle by giving examples of some of the spiritual gifts discussed in Chapter 12: an example of prophecy (Chapter 15), examples of administrative issues (16:1-21), and a legitimate example of speaking in tongues, which makes correct use of both the word anathema and the phrase marana tha (16:22). A final greeting follows (16:23-24).

${ }^{141}$ See above, section 6 .

142 See above in this section.

${ }_{143}$ See PT Moed Qatan 3:1,81 c-d, and see above, section 6.

${ }^{144}$ BT Moed Qatan 16a. See Leibson 1979-80:190-192.

145BT Moed Qatan 16a, 17a. See Buechler 1901:54.

${ }^{146}$ See Baer 1950:24-25; Albeck 1960:102. 
(Ezra 10:8) - in light of the Geonic herem. ${ }^{147}$ Thus, according to this midrash, a quorum of ten men was required for the herem of Joseph's brothers; since Reuben was absent, God was counted as the tenth. Similarly, the oath binding the people of Jabesh Gilead to send men to Mizpah (Judges 21:5) was not actually taken by each of the Israelites; it was a communal enactment enforced by a communal herem.

\section{[10] Herem and Community}

The one element common to nearly all of the meanings of herem described above is the element of community. Although the priestly gloss in Leviticus 27:28a, which refers to a personal dedication as herem, seems to belie this notion, we have seen that even the herem of persons mentioned in this verse may encompass a mutual vow of immolation vowed by a group united for a common purpose. ${ }^{148}$ In the common era, the sanction used to enforce this type of vow becomes a form of excommunication or ostracism from the group, and ultimately herem becomes a term for both excommunication and communal enactments. Even the "personal" ban of the Mishnah is a disruption of communal life, in that the two people involved are no longer in communion with one another, and must abstain from using communal property and services.

Let us summarize the development of the term herem over time:

The earliest biblical texts refer to the herem as a most sacred offering, rendered to God not by individuals, but by the community or the authorities on behalf of the community. These texts refer to herem most often in the context of war, but also in the context of the punishment of the idolater in Exodus 22:19. The wartime herem, like other most holy offerings, engenders sancta contagion, and thus entire cities must be wiped out if devoted to God as a herem in the context of war. The idolater is also put to death as a herem primarily because he contracted contagion from his idolatrous offering, which according to these early biblical texts have a measure of sanctity.

In Deuteronomy and the Deuteronomistic literature, the wartime herem is merged with the idolatry herem and explained as a safeguard against the spread of idolatrous practice among the Israelites. It is thus applied wholesale to all the conquered peoples of Canaan. In such a context, strict application of the contagion was dispensed with because it was impractical, since it would render all the booty of Canaan off-limits to the Israelites. However, the contagion was retained in the herem

\footnotetext{
147 See Buechler 1901:69-71.

${ }^{148}$ Even Peter's "personal" anathema can be seen as a communal sanction. In denying Jesus, Peter separates himself from the apostolic community in its hour of need; he therefore feels it necessary to make himself anathema.
} 
against an idolatrous Israelite city, which is destroyed entirely as an offering to the Lord. The communal nature of the herem is thus enhanced in Deuteronomy: the herem is not only an offering by the people, it is an offering designed to protect the community-from bad influences.

According to most scholars, the priestly code knows nothing of the wartime herem; in fact, the herem of the priestly code is usually not considered a communal enterprise at all. According to Leviticus 27:28a, the herem is a type of personal vow, rendered irrevocable by the votary, and commentators and scholars have tended to view all references to herem in the priestly literature in this light. In our view, the earliest strata of the priestly code contain two distinct conceptions of the wartime herem: the herem of these texts is property devoted by the community in the context of war or as a punitive measure, as in the other pentateuchal sources. According to the last three words of Leviticus 27:21 and according to Numbers 18:14, property devoted to God in the context of war or the campaign against idolatry is given to the priests as their personal, non-contagious, possession, as in Numbers 31 (which, however, does not use the term herem). According to Ezekiel 44:29 and Leviticus 27:28b-29, however, this property is qodesh qodashim, contagious sancta, as in the other sources. Leviticus $27: 28 \mathrm{a}$ is a late harmonizing gloss, which provides a completely new definition of herem designed to encompass both views: a herem is a personal offering of property or persons to God, which can presumably be given either to the priests or immolated. This is in fact how the Rabbis understood the herem. However, this ad hoc definition of herem is not consonant with the other biblical evidence: Leviticus 27:28a is the only biblical verse in which herem is a personal, rather than communal, offering.

The communal herem can be applied to fellow Israelites, whether idolaters or others who accept upon themselves the fate of a human sacrifice. This type of herem is found in Judges 21 , as well as in the pact herem of Second Temple sources, in which a group of conspirators agreed that anyone who violated the terms of the pact would be rendered herem. This herem carries the communal element one step further than Deuteronomy: the herem not only protects the community against outsiders, but becomes a mean of enforcing communal discipline. The conspiracy herem, hitherto unidentified as a particular type of herem, is found in I Enoch 6:1-6, Testament of Zebulun 1:6, CDC IX,1, and Acts 23:12-14. According to the Qumran literature, ritual immolation was no longer possible as the means of carrying out the herem, and therefore the victim was handed over to the authorities to be put to death on a trumped-up charge.

Other Qumran texts indicate that in practice the "death sentence" under such a herem was commuted to excommunication. The connection 
between the biblical herem offering and the rabbinic use of the term in the sense of excommunication has hitherto not been satisfactorily explained. In our view excommunication was originally a safeguard against the contagion imparted by the herem victim until his death, but it later became a punishment in its own right. This, combined with the fact that a homonymous Semitic root $\square$ means "cut, cut off," engendered the use of herem both in the sense of excommunication and in the sense of communal decisions, the violations of which are punishable by excommunication: communal commitments par excellence. 



\section{4}

\section{QONAM, KINNUI, and QONAS: Substitute Vow Formulae}

\section{[1] The Kinnuyim of Mishnah Nedarim 1:2}

The next three votive formulae mentioned in the Ashkenazic version of the Kol Nidre prayer are qonam, kinnui, and qonas. ${ }^{1} \mathrm{~A}$ kinnui is a formula that can be substituted for one of the original votive formulae; qonam and qonas are two of the substitutes for the vow formula qorban. The kinnuyim are post-biblical in origin; those sanctioned by the Rabbis are listed in Mishnah Nedarim 1:2:

If one says:

- these are considered substitute qorban ${ }^{2}$ formulae.

- these are considered substitute herem ${ }^{3}$ formulae.

- these are considered substitute nazir ${ }^{4}$ (Nazirite)

formulae.

\footnotetext{
${ }^{1}$ These formulae appear (in the plural form) in different forms in the prayer books of the various rites. The earliest versions of Kol Nidre known to us, preserved in the Geonic literature, have ply only (see introduction to Goldschmidt 1970:26-27). The Sephardic prayer book has pונמי, קונחי, a reading which is based directly upon Mishnah Nedarim 1:2: קונם , קונח , these are considered substitute qorban formulae." This reading probably underlies the Ashkenazic reading, קונמי, כינויי, קינוס, but in the Ashkenazic version the second formula מונחי ("substitue formulae" in general), and the vocalization of the third word, מונסי, מינוי" has been corrupted to מינוסי

${ }^{2}$ For the qorban vow, see above, Chapter 1.

${ }^{3}$ See above, Chapter 3.

"In the formula הריני נזיר, "I am hereby a nazirite," which is a binding votive formula.
} 
מבותה, שבוקדה, שקוקה - or if one vows by מוהה [ore are considered substitute shevi'ah (oath) formulae.

J. N. Epstein ${ }^{6}$ distinguishes between two types of substitute formulae (kinnuyim) in this mishnah. ${ }^{7}$ The first substitute qorban formula, qonam, is in his view a Phoenician oath formula ${ }^{8}$ which for some reason was current in Palestine, while all the other substitutes are deliberate corruptions of the terms qonam, herem, nazir, and shevu'ah. This represents a compromise between two amoraic positions as cited in BT Nedarim 10a: ${ }^{9}$

5"Vows" in this context means "swears;" see Epstein 1938:10, note 4; Lieberman 1942:117-118, and literature cited in notes 13-19 there. The manuscripts of the

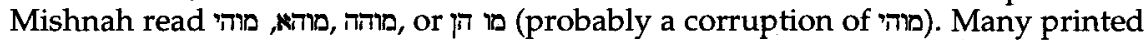
editions of the Mishnah have מות a secondary reading based upon the erroneous interpretation of this formula as a substitute for the Aramaic word wns, "oath" (see below, note 24). For complete documentation of the variants, see Lieberman 1967:396, note 11; Hershler 1985:70-71.

${ }^{6}$ Epstein 1938:10-11; Epstein 1957:376-377.

${ }^{7}$ Another type of substitute formula is found outside this mishnah: ordinary Hebrew words that serve to describe the type of vow being undertaken. See Mishnah Nazir 1:1, and Epstein 1938:10.

${ }^{8}$ See below, section 2 .

${ }^{9}$ The BT version of the dispute between Rabbi Yohanan and Rabbi Simeon ben Laqish is a generalized, "stylized" account of a dispute that originally referred to a specific, post-tannaitic, substitute naziriteship formula: פיק. Note that in BT Rabbi Simeon ben Laqish uses the word לשון, "expression," in the singular, although the plural is required in context. More original versions of the two statements have been preserved in PT Nazir 1:1 (51a). The sugya there has been interpreted in a number of ways, but most of these are problematic (see detailed analysis in Benovitz 1996, appendix). The PT passage should be translated and understood as follows:

נוז.... (Mishnah Nedarim 1:2):

[What of]

Rabbi Yohanan said: "No one may add to the expressions that the Rabbis selected (בררו)."

But did not Rabbi Hiyya teach [the following baraita]: "חיח,

Rabbi Shila said: "No one may add to the expressions selected in tannaitic literature." [But Rabbi Hiyya's formulae are valid, since they are mentioned in a baraita.]

[There follows an extraneous passage erroneously transferred from PT Nedarim 1:2 (37a).]

Rabbi Simeon ben Laqish said: "It [i.e.p Simeon ben Laqish was probably originally referring to the Greek noun peskos, "sheared hair," derived from the verb pokizein, "to shear," a reference to the Nazirite's shaving of his head at the end 
It was said of substitute formulae:

Rabbi Yohanan says that they are the language (לשון) of the nations; Rabbi Simeon ben Laqish says that it is an expression (לשון) that the Rabbis made up (בדו) with which to vow.

According to Epstein, qonam is "the language of the nations," while the other formulae in the Mishnah are expressions made up by the Rabbis. ${ }^{10}$ In a parallel passage in PT Nazir 1:1 (51a) Rabbi Yohanan refers to "expressions that the Rabbis selected (ברוn)," rather than expressions that the Rabbis made up (בדו), but Epstein suggests emending the word בררו), "selected," in PT to בדו, "made up," which would accord with BT.

S. Lieberman, by contrast, stresses the popular origin of the substitute formulae. According to Lieberman, the use of substitute formulae by the masses was rooted in a fear of the magic power of oath and vow formulae, common in the ancient world. ${ }^{11}$ He accepts the PT version of Rabbi Yohanan's statement, and argues that even בדו in BT can be understood in the sense of "selected." 12 The substitutes originated in popular usage, and the Rabbis had only to "select, regulate, and sanction" those formulae that they considered appropriate. ${ }^{13}$ Lieberman apparently believed that these formulae are more than simply nonsensical corruptions of the various votive terms, since in his view the Rabbis selected appropriate terminology from a pool of popular terms, and then "regulated" them before validating them.

In fact, it is quite clear that these terms are neither mere nonsense words nor foreign words. Most of the formulae mentioned in the

of the period of naziriteship (for the words peskos and pokizein elsewhere in rabbinic literature, see Lieberman 1955:670-671). Since פיק is an appropriate foreign term for Nazirite, it would presumably be valid.]

Rabbi Zeira [understanding Rabbi Simeon ben Laqish's statement differently than we have explained above] said: "It is Nabatean. For the Nabateans pronounce son ('pottery') like כo ('silver')." [They would thus presumably pronounce the mishnaic formula or פי].

Rabbi Yose said: [Rabbi Yohanan's] statement would seem to be correct elsewhere. But in a place [such as Nabatea] where they call a

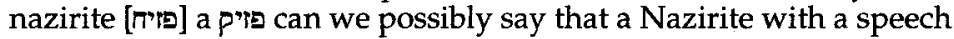
defect is not a Nazirite?

For detailed discussion and commentary, see Benovitz 1997, appendix.

${ }^{10}$ Epstein 1938:10, note 2.

${ }^{11}$ Lieberman 1942:124, 139. Epstein also believes that the substitute formulae were formulated by the Rabbis on the basis of popular usage. See Epstein 1938:10.

${ }^{12}$ Lieberman 1942:17, and note 14 there.

${ }^{13}$ Lieberman 1942:116. 
mishnah consist of well-known Hebrew or Aramaic roots. Each of these roots is related in terms of content to the original votive term for which it is meant to substitute, and each root differs by one letter only from the root of the original term. The roots of the substitute formulae have also been "regulated:" they have been declined and vocalized according to the pattern of the original formula.

The substitute oath formulae שבותה and are formed from the שבת Aramaic root ("abandon") and the Hebrew/Aramaic root ("cease, desist"), which have been declined according to the pattern of the word shevu 'ah, "oath." These roots differ by one letter only from שבע, the root of the word shevi ah, and they are clearly related to the concept of oath: if a person swears not to eat, for example, he abandons his food and desists from eating it. The Aramaic root שבק is foreign in the sense that it is not Hebrew, but it was chosen not because it is a foreign oath formula, but because it is a word in the Palestinian vernacular which is similar in both sound and content to the word shevi ah, "oath." The third substitute oath formula, שקp, from the root $\mathrm{P}$, "desire," is apparently based upon the notion that the forsworn object becomes an object of desire. This formula differs by one letter only from the first substitute oath formula שבוקה, and in effect constitutes a substitute of a substitute, which according to this mishnah are also valid formulae (see Tosefta Nazir 1:1, 2:1). ${ }^{14}$

The substitute formulae שבותה, שבוקה, and שקוקה replace the formula shevu ah, which is the most common rabbinic oath formula (see Mishnah Shevuot 3:1 and passim in that chapter). But there are other oath formulae that do not make use of the word shevu ah, "oath," itself. The biblical oath formula consists primarily of an invocation of the divine name, ${ }^{15}$ and rabbinic literature also refers to oaths using various names of God. ${ }^{16}$ Formulae in which another noun is substituted for God's name are usually considered invalid, ${ }^{17}$ but according to Tosefta Shevuot 2:16 an oath "by the Torah" is valid, ${ }^{18}$ and a number of amoraic sources cite an

\footnotetext{
${ }^{14}$ The term כינויי כינויין 1:1 probably originally referred to words such as (פקוקה (and for which see below). See Lieberman 1967:503. But see Tosefta Nazir 2:1, PT Nazir 1:1 (50c), and BT Nedarim $10 \mathrm{~b}$.

${ }^{15}$ See below, Chapter 5 .

${ }^{16}$ See Mishnah Shevuot 4:13. The oath formula האלהים ("by God!) is commonly used by Babylonian amoraim. See Berakhot $24 b$, Shabbat $94 b$, and passim.

${ }^{17}$ E.g. "by heaven and earth," Mishnah Shevuot 4:13. See also Lieberman 1942:125-141 and below, Chapter 5.

${ }^{18}$ The extant manuscripts and editions read: "If he says 'I swear,' he is liable; 'by the Torah' or 'by Heaven,' he is not liable." But all the medieval citations of the passage read "If he says 'I swear by the Torah' he is liable." See Lieberman 193739, volume 2:176; Lieberman 1967:402-403, note 34 .
} 
oath formula "by Moses,"19 which may be a shortened form of an oath "by the Torah of Moses."20 The Talmud and many commentators and scholars ${ }^{21}$ understand the phrase "if he vows by מורה/מוהא/22 as a substitute for the oath "by Moses." This substitute also fits the pattern described above: מוהז are two declensions of the Aramaic word for water (מוהי = מוהז = his water water). This substitute formula, if spelled מוהה, differs by one letter only from the name Moses spelled plene: מושה, 23 and the connection between Moses and water is obvious ("for I drew him from the water," Exodus 2:10). ${ }^{24}$

The substitute naziriteship formulae, which are valid when invoked instead of the word nazir in the formula הריני ניור, "I am hereby a Nazirite," also fit this pattern. The formula נr is derived from the

${ }^{19}$ Rabbi Haggai swears by Moses in PT Yoma 1:1 (38c) (although our editions have the corrupt reading משה instead of Taanit 4:1 (67b); Megillah 4:8 (75c); Nazir 5:1 (54a); Sanhedrin 2:1 (19d); and Horayot 3:2 (47a) (our versions have the corrupt reading מופב). Rav Safra swears by Moses in BT Shabbat 101b; Betsah 38b; Sukkah 39a; Hullin 93a.

${ }^{20}$ Lieberman 1967:396, note 14. For "Moses" as shorthand for "the Torah of Moses," see also II Corinthians 3:15. The Rabbis legitimized oaths by Moses because they conceived of these oaths as shorthand for oaths by the Torah of Moses, but it may be that the oath formula itself originally reflected a reverence for Moses himself. See Josephus, War II, 145. (This was suggested to me by Hillel Newman.)

${ }^{21}$ See below, note 24 .

${ }^{22}$ See above, note 5 .

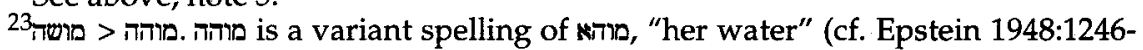
1247). The readings מוזה reflect the usual orthography of the words for "his water" and "her water" respectively, while the orthography of sim has been altered in other witnesses to the rarer form מוזה in order to make the orthography of the substitute formula conform more precisely to that of the name Mosheh (משר).

${ }^{24}$ Note also that Philo (De Vita Mosis I, 17) and Josephus (Antiquities II, 228) write that Pharaoh's daughter chose the name Moses (Mouses in Greek), because mou in Egyptian means water.

The interpretation of the term מורזי/מודה/ מודה cited here is clearly the original and correct one; see Tosefta Nedarim 1:2, PT Nedarim 1:2 (37a), and BT Nedarim $10 \mathrm{~b}$, which explain the vow "by מודי" as an oath akin to the oath that Moses swore to Jethro (Exodus 2:21, according to the rabbinic interpretation; see Rashi). Cf. also Ran to BT Nedarim 10a; Lieberman 1967:396-397.

According to others, however, the term מוהי is a substitute for the Aramaic word מומי or, "oath." See, for example, Rashi to BT Nedarim 10a; Albeck 1959, ad loc. This interpretation, however, is unlikely, for the following reasons: (1) Sources as early as the Tosefta already understand מוהי as a substitute for Moses (see above); (2) מומתא/מומיא means "oath," but unlike the word iעועה, it is never attested as an oath formula (in fact, BT Shevuot 26a cites an Aramaic oath formula using the word שבועתא, an Aramaized form of the Hebrew (בבועה); (3) (3) phrase "if one vows by Mohi (במוהי) indicates that the word מוהי is something to swear by, i.e. a substitute for the divine name. 
Hebrew root ("damage"), while the formula is based upon the Hebrew word (Exodus 28:28, BT Hullin 7a; the niph al form of the verb $\pi \Pi$ ז $/ \Pi$, "to be pushed aside"). The former term reflects the widespread notion that the ascetic Nazirite causes damage to himself, found for example in Rabbi Eleazar haKappar's famous statement in Sifre Bemidbar 30: "How did the nazirite sin, that he is required to atone [by bringing a sin-offering]? By depriving himself of wine." The term "pushed aside," reflects the fact that the nazirite is separated from society, a notion that underlies the word itself, which also means "separated." Both נויר differ from the original term and by one letter only.

The third substitute naziriteship formula, two Hebrew roots and $\mathrm{m}$, both of which mean "to act with reckless haste." The nazirite, like other votaries, is thought to have acted somewhat recklessly in taking upon himself additional religious requirements (see Ecclesiastes 5:1, 5-6). However, since both have only one letter in common with the root of the word nazir, רנ, the Rabbis selected the substitute formula פinstead, which differs by one letter only from the substitute formula נזיח, and constitutes a "substitute of a substitute."

The substitute herem formulae, חרק, חרך, also differ by one letter only from the original, חרם. These are also related to the original in content: The root is used along with the root in the sense of curse or blaspheme (see, for example, II Kings 19:22 = Isaiah 37:23), and in Isaiah 43:22 the word herem is found in synonymous parallelism with the word גידופים, and thus can also be understood in the sense of "curse."25 The formula חר is likewise related to "curse:" the phrase שרק, literally "gnash teeth," is an expression meaning curse (see Psalm 35:16, Lamentations 2:16). The root 7 , which means "singe, burn," is related to herem in the sense that the biblical herem is often consigned to flames.

The roots of the substitute formulae for herem, naziriteship, and oath, are thus common Hebrew or Aramaic roots, which resemble the original formulae herem, nazir and shevi ah in both sound and meaning. These roots have been declined and vocalized in accordance with the patterns of the original terms. The substitute formulae probably originated in popular usage, and the Rabbis selected the valid terms mentioned in our mishnah from a pool of such popular terms, as suggested by Lieberman. They are neither foreign votive terms nor nonsense words.

${ }^{25}$ But see above, Chapter 3 , note 96. 


\section{[2] Qonam is not a Phoenician Term}

The substitute formulae for herem, naziriteship, and oath thus fit a rigid pattern. Each is derived from a common Semitic root. Each differs from the root for which it is meant to substitute (or from another substitute for the original root) by a single letter. Each is semantically related to the original votive concept, and each has been vocalized in accordance with the vocalic pattern of the votive term for which it is meant to substitute.

The substitutes for the qorban formula, קונס , pare likewise vocalized according to the vocalic pattern of the word qorban $(\mathrm{CoCaC}) .{ }^{26}$ But unlike the other substitute formulae in the mishnah, which are derived from common Semitic roots that resemble the original, these terms are not derived from known Semitic roots, and their meaning is thus unclear. Moreover, all of them differ from the word qorban by more than one letter. In fact, only the initial letter $p$ is common to qorban and its substitutes. שמקו also differ significantly from nazir and shevu'ah, the terms for which they are meant to substitute, but these are technically substitutes of the substitute formulae נבוקה and respectively. By contrast, even the initial substitute formula, קוני from the word pר.

Contemporary Talmud scholars tend to see the word qonam as a Phoenician loan word. ${ }^{27}$ The term occurs only once in the Phoenician

\footnotetext{
${ }^{26}$ Since the word qorban is quadriliteral, the first syllable is closed, and therefore the /o/ is short (jop rop); in the triliteral substitute formula, the /o/ becomes long (חולם) because the first syllable is open. But the /o/ sound has been retained. The Kaufmann and Parma manuscripts of the Mishnah read qunnam, qunnah, and qunnas, vocalizations which seem to be designed to make the substitute formulae seem more exotic or nonsensical, in accordance with BT's understanding of the nature of the substitutes. But even this vocalization can be considered analogous to qorban, which is sometimes vocalized qurban (see Nehemiah 10:35). In Mishnah manuscripts with Babylonian vocalization qonam is pointed qunam, and qorban is pointed qurban (see Porat 1938:117-118, 136-137).

${ }^{27}$ Epstein 1938:10; Epstein 1957:376-377; Albeck 1959 ad loc. Lieberman 1942:129, note 106 rejects the Phoenician etymology on the basis of Torrey 1912 (see below, note 33), and he alludes to the fact that H.L. Ginsberg also rejected the alleged etymology. But in the Hebrew edition of the same work (Lieberman 1963:98, note 106), Lieberman leaves the question open.

A number of scholars of Phoenician also accept this etymology. All of these scholars, however, were interested in showing links between Phoenician and Hebrew. The first to explain the Phoenician term as a term of adjuration was Stade 1875:223; his article is entitled "Erneuete Pruefing des zwischen dem Phoenicischen und Hebraeischen bestehenden Verwandschaftgrades." He is followed by Driver 1913:xxv (Notes on the Hebrew Text of the Book of Samuel) and a number of Israeli scholars: Segal 1928-1929:225; Avishur 1979, volume 2:191-192; Kutscher 1975:18; Greenfield 1976:60.
} 
corpus, in the fifth century B.C.E. inscription on the tomb of Eshmunazar, king of Sidon:

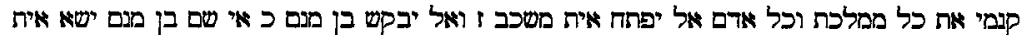

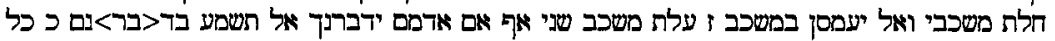

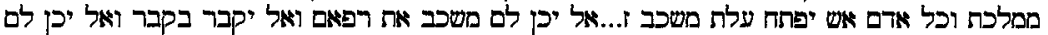
בן נחרע תחתנט. 28

Y. Avishur translates as follows:

My qonam is with every king and every man: Let him not open this bed of mine and let him not seek anything in it, for there is nothing there, in it. And let him not carry this coffin of my bed and let him not carry me away from this bed onto another bed. Even if people speak to you, do not listen when they speak (?), for any king and any man who opens upon this bed...they shall not have rest among the Rephaim, and he shall not be buried in a grave, and they shall not have son or seed after them. ${ }^{29}$

According to this interpretation, pנממ means "my oath" or "my adjuration." When the Rabbis sought a substitute for the qorban vow formula, they found this Phoenician adjuration formula beginning with $p$. On the pattern of this formula they created the additional substitute formulae pand pis. ${ }^{30}$

But this purported word for "oath" occurs only once in the Phoenician corpus. It is therefore hard to imagine that the Hebrew qonam is a Phoenician loan word. Moreover, most scholars of Phoenician do not consider the word pin the Eshmunazar inscription an oath formula at all. The sentence in which the word pup is found bears a striking resemblance to a sentence found in the tomb inscription of Eshmunazar's father, Tabnit:

$$
\text { מי את כל אדם אמ חפק אית הארן ו אל אל תבתח עלתי ואל תרגן }
$$

which Avishur translates: "Whoever you are (=whoever you may be), any man who finds this coffin, do not, do not, open upon me and do not

${ }^{28}$ For the text see Avishur 1979, volume 2:188; Donner and Roellig 1964, volume 1:3 (no. 14); Gibson 1982, volume 3:107.

${ }^{29}$ Avishur 1979, volume 2:188 (translated from Avishur's Hebrew translation). For other translations, which differ with that of Avishur on a number of points, see Rosenthal in Pritchard 1969:662; Donner and Roellig 1964, volume 2:19; Gibson 1982, volume 2:107. And see immediately below, and below, note 33 .

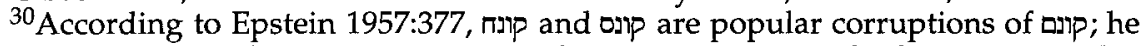
believes that the same is true of $\pi, \pi$, ניונ, which are popular mispronounciations of nazir. But we have already seen that the latter are carefully chosen substitute formulae, selected and regulated by the Rabbis according to strict criteria.

${ }^{31}$ Avishur 1979, volume 2:171; Donner and Roellig 1964, volume 1:2-3 (no. 13); Gibson 1982, volume 3:103. 
upset me."32 The phrase מי את כל אדם, "whoever you are, any man" resembles the phrase קנמי את כל ממלכת וכל אדם כלם "Wnmy you are, any king or any man" in the Eshmunazar inscription, which leads most scholars of Phoenician to understand the word pas a synonym of the word in the sense of "anyone at all, whosoever." 33 The word is considered a

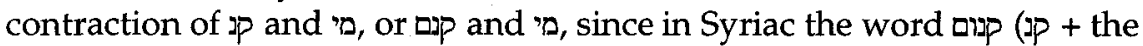

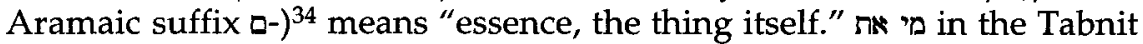

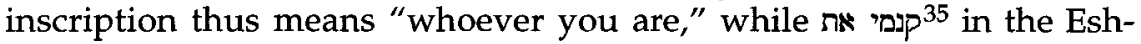
munazar inscription means something like "whosoever at all you are."

Avishur, however, cites four reasons for preferring the interpretation of pas an oath formula: ${ }^{36}$

1. Mishnah Gittin 4:7, "It happened in Sidon that a man said to his wife, "qonam if I do not divorce you'", clearly shows, in Avishur's view, that the Sidonian/Phoenician pis related to the rabbinic qonam.

2. The Talmud states that the substitute formulae are foreign terms, ${ }^{37}$ and Lieberman writes that "one who insists upon adjuring in a foreign language is considered worthy of praise." 38

3. H. Ehrentreu has cited other evidence of points of contact between Phoenician and Rabbinic Hebrew. ${ }^{39}$

4. The alternate explanation of p in accordance with Syriac pup creates a syntactical problem according to F. Rosenthal. ${ }^{40}$

However, none of Avishur's arguments stand up to careful scrutiny. Let us analyze them one by one:

1. In Mishnah Gittin 4:7 we read: "It happened in Sidon that a man said to his wife 'qonam if I do not divorce you."' Since this event took

${ }^{32}$ Avishur 1979, volume 2:171.

${ }^{33}$ So Lizbarski 1902-1915, volume 2:164; Torrey 1912:83-84; Torrey 1937:407-408; Friedrich 1951:52; Rosenthal 1952:173; Rosenthal in Pritchard 1969:662; Donner and Roellig 1964, volume 2:21; Gibson 1982:98; Segert 1976:181.

Cooke 1903:33-34 and Levias 1933:212-213 connect Phoenician pup to both Syriac קונם and the rabbinic in his own way, which see. Their explanations are, however, rather far-fetched.

${ }^{34}$ The suffix $-m$ in this word is the Aramaic adverbial suffix found in the words ברום ("however") at all"). See Torrey 1937:407.

35If the word "מק means "my oath" or "my adjuration," then the following word ת means "with" (see below, at the end of this section, and note 49 below). If the word pני means "whoever," then the following word nk means "you [are]."

${ }^{36}$ Avishur 1979, volume 2:192.

${ }^{37}$ See above, section 1 .

${ }^{38}$ Lieberman 1962:93.

${ }^{39}$ Ehrentreu 1912:193-197.

${ }^{40}$ Avishur cites Rosenthal 1952:173. But see below. 
place in Sidon and the Eshmnazar inscription is from Sidon, Avishur sees this as conclusive evidence that pup in the Eshmunazar inscription is an oath formula. But during the mishnaic period Phoenician was not spoken in Sidon, and the term pis nowhere found in Aramaic and Greek literature from Phoenicia. Moreover, the mishnah in Gittin is referring to a Jew from Sidon; the vow formula he is purported to have used is the Mishnah's own Jewish vow formula, attested over sixty times in the Mishnah, and not a formula used by Sidonians of Phoenician descent who may or may not have preserved Phoenician phrases in their own dialects. Furthermore, H. Albeck believes that the Sidon mentioned in this and other mishnayot is not the Phoenician Sidon, but the town of Beth Saida or Saidan on the northeastern shore of the Sea of Galilee. ${ }^{41}$ In fact, however, the phrase "It happened in Sidon" occurs so often in rabbinic literature ${ }^{42}$ that it stands to reason that it is a stock phrase used in rabbinic legend, which does not necessarily indicate an actual event that took place in either Sidon, or any connection with Sidonian life.

It is therefore doubtful whether the event discussed in Mishnah Gittin 4:7 took place at all in Sidon, and if it did, it is not clear whether the Sidon referred to is the one in Phoenicia. Qonam is the Mishnah's usual vow formula, and nothing can therefore be learned from the fact that a Sidonian Jew is said to have made use of this formula.

2. Rabbi Yohanan's statement as reported in BT, to the effect that the substitute formulae in the mishnah are foreign terms, has been taken out of context. The original amoraic statement (which is attributed to Resh Laqish, not Rabbi Yohanan) is found in PT Nazir 1:1 (51a). Resh Laqish there is referring not to the substitute formulae in the mishnah, but to another, post-tannaitic, substitute naziriteship formula, which he says is a foreign term. ${ }^{43}$

The citation from Lieberman refers to adjuration formulae found in amulets, which are not true votive formulae at all, but magic formulae. Lieberman simply made the common-sense remark that

\footnotetext{
${ }^{41}$ Albeck 1959, volume 3:404, 416; volume 4:490. See also Klein 1939:129; Reeg 1989:533-534.

${ }^{42}$ Four times in the Mishnah (Ketubot 7:10; Gittin 4:7; Gittin 7:5; Avodah Zarah 3:7), thrice more in the Tosefta (Avodah Zarah 3:7 [a different incident than the one in the Mishnah!]; Parah 2:1; Niddah 4:6), and once in a BT baraita (Shabbat $115 b)$. In the parallel to this last baraita in Tosefta Shabbat 13:4 no place name is mentioned, which supports our contention that the place name Sidon was sometimes added secondarily to reports of incidents in order to add "color." ${ }^{43}$ See above, note 9 .
} 
magic formula sound more magical if they are uttered in a foreign tongue. Needless to say, qonam is not a magical formula at all, and thus this citation is completely irrelevant.

3. The so-called "points of contact" between Phoenician and Rabbinic Hebrew cited by Ehrentreu are in fact one single point of contact: ${ }^{44}$ the addition of the letter $n$ before noun suffixes. In Phoenician one case is attested: the plural of the word sא, "god," is rather than אלם as one might have expected. Similarly the form is found twice in the late rabbinic Hebrew of BT (Eruvin 64a, Hullin 51a) instead of שמי, "my name." However, scholars of Phoenician consider sלניום to be the plural of הלן, "god" (על + עלי ון עליון, compare Hebrew, from and thus this word can in no way explain the unusual morphology of the word שמנ in BT.

4. In his fourth comment Avishur confuses the positions of a number of scholars. Many scholars do in fact object to the notion that Phoenician קנמי is the Syriac itself, because the Syriac documentation is much later than the Phoenician, and the adverbial suffix $-m$, typical of Aramaic dialects such as Syriac (cf. ברם, "however" and כלום, "at all"), is not attested in Phoenician. The consensus view is therefore that an ancient Semitic word ip underlies both Syriac a pup and Phoenician p, which is combined with "who," in the form pus far as etymology is concerned, C.C. Torrey connects the word with Persian gon, "color," found in the Aramaic forms כבגון, "like," and בגין, "because." 46 In the article cited by Avishur, Rosenthal suggests unequivocally that $i p$ is the imperative form of the root $\mathrm{up}^{4}{ }^{47}$ he sees no difficulty whatsoever in defining Phoenician p in the sense of "whoever."

No one would have suggested that psip in the Eshmunazar inscription means "oath" were it not for the rabbinic term put we have seen above that the other substitute formulae in Mishnah Nedarim 1:2 are not foreign terms at all, and therefore if we were to accept the Phoenician derivation of qonam, qonam would be exceptional. Moreover,

${ }^{44}$ Other genuine points of contact between Phoenician and rabbinic Hebrew are cited by Rendsburg 1992:225-240. However, all of these are already found in the northern dialect of biblical Hebrew.

${ }^{45}$ See Donner and Roellig 1964, volume 2:14-15; Harris 1939:37.

${ }^{46}$ Torrey 1937:407.

${ }^{47}$ Rosenthal 1952:173.

I would like to propose another possibility. Perhaps the element $\mathbb{P}$ is the passive participle of the verb p p "to create," with the sense of "creature, being." Cf. U. Cassuto's explanation of the name j'P, "Cain" (Cassuto 1969:197-198). In that case, Phoenician "מp would be the equivalent of the English "anybody who." 
the qorban vow is not an oath at all; it is derived from the dedicatory vow, as we have seen above. It would make no sense therefore for the Rabbis to choose a Phoenician oath formula as a substitute $v o w$ formula. ${ }^{48}$

Most significant, however, is the fact that the pukes no sense as an adjuration formula in the Eshmunazar inscription. את in Phoenician means "with;" קנמי את כל ממלכת וכל ארם would have to mean "my oath is with every king and every man," 49 and indeed, this is how Avishur translates the phrase. However, an adjuration is the imposition of an oath upon others, not with them. The Tabnit inscription parallel shows conclusively that whatever its precise etymology may be, קנמי a synonym of מי, "who, whoever."

\section{[3] Greek Koinon and Hebrew Qonam}

If qonam is not a Phoenician formula, what is it? The word is vocalized according to the pattern of qorban, but other than that it does not resemble gorban in sound, and its meaning is a mystery.

As we have seen in Chapter One, ${ }^{50}$ a qorban vow is a vow of consecration in which a person donates to the Temple the very property that he will use or give to another to use. He has no intention of actually donating the property to the Temple; he simply wishes to create a paradoxical situation in which the property becomes off-limits to himself or to whomever is mentioned in the vow, because the moment he or they derive benefit from the property in question, it becomes Temple property, and they are guilty of misappropriating Temple property. As we have seen, an example of this type of vow is found in Matthew 15:3-5:

(3) He answered them: 'And what of you? Why do you break God's commandment of God in the interest of your tradition? (4) For God said, "Honour your father and mother" ... (5) But you say, "If a man says to his father and mother, anything of mine which is used for your benefit is set apart for God [=qorban]," then he must not honour his father or his mother.

After the destruction of the Temple, when the Temple treasury was no longer in existence, the Rabbis reinterpreted the qorban vow as likening

\footnotetext{
${ }^{48}$ According to Epstein 1957:376, the Rabbis did not mind using a Phoenician oath as a vow formula, because confusion between oaths and vows is attested elsewhere in rabbinic literature, and sometimes the Rabbis sanctioned such "mistakes." However, even if the Rabbis sometime approved such vows after the fact, it is hard to believe that they would deliberately establish a vow formula that is based upon a Phoenician oath.

${ }^{49}$ Epstein erred on this count. He translated קממי את כל ממלכת, "I adjure every king...," taking את as the nota accusativi, as in Hebrew (1938:10; 1957:376). But the Phoenician nota accusativi is not not.

${ }^{50}$ See above, Chapter 1 , sections 2 and 3 .
} 
the prohibited object to an offering, rather than the actual consecration of property from which the votary or someone else is to derive benefit. ${ }^{51}$ But we have found evidence that some continued to consider the prohibitive vow formula a true (if paradoxical) vow of consecration; not all of the tannaim adopted the new "likening" conception. ${ }^{52}$ The church father Origen, writing in the second century, also explains the vow in Matthew as a true vow of consecration, although the paradox seems to have escaped him; he seems to think that the parent's food was actually to be given to the Temple. ${ }^{53}$ Origen writes that the concept of the prohibitive vow was somewhat unclear to him, until a Jewish acquaintance explained it to him as follows:

Sometimes, he said, creditors who are faced with stubborn debtors, who are able to repay their debts but do not care to do so, dedicate the debt to the poor, for whom money is donated to the treasury by anyone who wishes to share (koinonein, literally: "hold in common") his property with the poor. They would say to their debtors in their own language, "what you owe me is qorban," i.e. gift, "for I have dedicated it to the poor out of fear of God." Then the debtor, who now owes his debt not to men but to God and the fear of God, is forced to pay his debt not to the creditor, but to God, to the poor fund, in the name of the creditor. And that which the creditor did to the debtor, sons sometimes did to their parents, saying, "the benefit which you would have derived from me, father or mother, you must now receive from the qorban, i.e. from the poor fund dedicated to God. The parents, upon hearing that that which was to be given them is gorban, dedicated to God, do not wish to take it from their sons, even if they are in desperate need of food. ${ }^{54}$

The case cited by Origen's acquaintance could not possibly be accurate, since a loan is meant to be spent. The money lent is no longer in the possession of the creditor, and therefore he cannot pledge it to the Temple or to anyone else. Perhaps Origen misunderstood his acquaintance, who was originally referring to a lent object, which must be returned intact, and therefore can still be considered the possession of the creditor. In any case, it is clear from this description that the solution proposed by the Rabbis in their attempt to maintain the institution of the qorban vow even after the destruction of the Temple (the reinterpretation of the qorban vow as a vow likening an object to Temple property), was not the only solution. Others continued to vow gorban vows in which the food or property used was donated retroactively to charity, rather than

\footnotetext{
${ }^{51}$ See above, Chapter 1 , section 7 .

52 See above, Chapter 1 , section 7 .

53 See above, Chapter 1, section 3; Baumgarten 1984-85:14 and note 6 on pp. 5-6.

${ }^{54}$ Origenes, Matthaeuserklaerung, in Die Griechische Chrisliche Schriftsteller, volume 40 (Leipzig 1935), pp. 47-48.
} 
to the Temple. Just as actual donations to charity no doubt replaced offerings to the Temple in the popular mind, the prohibitive vow that took the form of a paradoxical Temple offering was replaced by a prohibitive vow that took the form of a paradoxical donation to charity. The votary would state, "that which you will benefit from me is hereby donated to charity," in which case the property was "given" to the poor fund the moment the person mentioned in the vow makes use of it, and the person mentioned in the vow is thus considered guilty of stealing from charity. The Greek verb that Origen uses for "donate to charity" is koinonein, "to share." In the New Testament we find that charity itself is termed koinonia, "sharing" (Romans 15:26; II Corinthians 9:13). Property donated to charity was termed koinon, "shared, common [thing]:" in Acts 4:32-35 the early Christians are said to have had no private property; all of their property was given to the apostles, and all was koina (the plural of koinon), "shared, common [property]" (verse 32), which was given to each according to his needs (verse 35).

In the first century C.E. the Greek adjective koinon was thus used to refer to property donated to charity. ${ }^{55}$ The word exists in three forms: koinon (neuter), koine (feminine), and koinos (masculine). At some point, presumably after the destruction of the Temple, it is only natural that the formula "koinon is that which you will benefit from me" or "koinos is the wine (oinos, a masculine noun) that I shall drink" replaced the earlier, obsolete formulae "qorban is that which you will benefit from me," and "qorban is the wine that I shall drink," respectively. koinon and koinos in these phrases mean "common, shared, donated to charity." It stands to reason that all three were originally used in Greek prohibitive vow formulae; the adjective agreed in gender with the noun, the object to be prohibited. At a later date the three were used interchangeably in Hebrew or Aramaic prohibitive vows, ${ }^{56}$ and koinon, koine, koinos are transliterated as the three substitute qorban formulae in our mishnah: קונים, and a

Other substitute formulae were probably also used by the masses after the destruction of the Temple instead of qorban. The Rabbis chose these three because they begin with the Hebrew letter $p$, as does the word qorban itself, just as they chose the other substitute formulae because they resembled the original terms.

${ }^{55}$ See Arndt and Gingrich 1952:438-440; Hauck 1972:789-809. Pינוני (koinonia) is found in rabbinic Hebrew and Aramaic (and in modern Hebrew) in the sense of "conspiracy."

${ }^{56}$ The word koinon was also translated into Hebrew as ("common, as opposed to sacred, food") for use in Hebrew and Aramaic vow formulae. See Tosefta Nedarim 1:3, Mishnah Nedarim 1:3, 2:1. See Benovitz 1996, section 5. 


\section{[4] The Transcription of Koinon, Koine, and Koinos}

The usual system of transcription of Greek employed in rabbinic texts would lead us to expect the forms pיניני , קיני koine, and koinos. However, the Greek adjectives were adapted in the Mishnah to conform with the substitute formulae system as a whole; and just as the vowels of the words herem, nazir, and shevu'ah were superimposed upon their substitute formulae, so too the vowels of the word qorban, /o/ and /a/, were superimposed upon the words koinon, koine, and koinos. ${ }^{58}$ is thus to be expected instead of pינוס we find the form for koinon, rather than for koine, rather than kנו or or ?

The Greek casing ending -on is transcribed with $\square-$ rather than the usual $\}$ - in the word qonam. This is the only such example in rabbinic literature ${ }^{60}$ However, a similar case is the word peganon, the herb "rue," 61 which is called פיג in rabbinic literature. ${ }^{62}$ But in the case of peganon, it is not the suffix -on that is transcribed as 0 -; the suffix has been apocopated, and the root letter $n u$ has been transcribed as $0 .{ }^{63}$ Nonetheless, it would seem that in both peganon and koinon $D$ replaces 3 for the purpose of dissimilation. Both words end in -non; in both cases the first $n u$ is part of the stem, while the second is the second declension neuter nominative ending -on. In order to avoid the double $n u$, the word peganon was transcribed פיגמן פיגנן instead and פיגן was later apocopated to פיגם Similarly, koinon was transcribed קונן rather than There are no other examples of an $n>m$ shift for the purpose of dissimilation in transcriptions of Greek in rabbinic Hebrew. ${ }^{64}$ According to $\mathrm{S}$. Krauss, the normal shift is $n>l$ or $n>r .{ }^{65}$ But he cites only one

\footnotetext{
${ }^{57}$ See Krauss 1898-99, volume 1:6,7,17,22.

58 See above, note 26 .

${ }^{59}$ Note that in other cases, too, the Greek case endings -on and -os are sometimes transliterated $\}$ - and 0 - respectively, rather than $\eta_{-1}$ and 0 -. See Sperber 1984:74.

${ }^{60}$ The Hebrew word גרדום, "platform, gallows," is probably not relevant here, even though the Greek cognate is gradon (the noun grados in the accusative case). Both Hebrew and Greek borrowed the word from the accusative form gradum of the Latin gradus. See Krauss 1898-99, volume 2:183; Sperber 1984:78-79. Another possibility, suggested to me by Hillel Newman, is that the Hebrew גרדום is a corruption of גרדוס (a form that is also attested in rabbinic literature, see Krauss and Sperber, ibid.) which is quite similar graphically.

${ }^{61}$ See Krauss 1898-99, volume 2:439; Loew 1924-1934, volume 3:317.

${ }^{62}$ Mishnah Kilayim 1:8; Sheviit 9:1; Uqtsin 1:2; Tosefta Shabbat 14:11; BT Shabbat 128a; BT Eruvin 34a.

${ }^{63}$ For some reason, Krauss 1998-99, volume 1:113 considers the final $\mathrm{a}$ in "Hebraization" of the Greek word.

${ }^{64}$ For the $n>m$ shift under other circumstances, see Krauss 1898-99, volume 1:99.

${ }^{65}$ Krauss 1898-99, volume 1:111.
} 
example of each, and both are from Latin, not Greek: annona > s, and Antoninus > אנטולינוס. Our shift $n>m$ should thus be added to the list of transcription shifts engendered by dissimilation in the case of double $n u$. It should be noted that in both of our cases the second $n u$ is part of the Greek case ending -on; in these cases $m$ may have been chosen instead of $l$ or $r$ on the analogy of the Latin case ending -um.

The form por koine probably originally read According to Krauss, final eta is usually transcribed ', but sometimes it is transcribed $\mathrm{T}$ or ${ }^{*}{ }^{66}$ In our case $\mathrm{n}$ is required instead of ' as a matris lectionis, since the word should be read with the vowel pattern of qorban: qonah, rather than qonei. The $\pi / \pi$ switch is a mere textual error. ${ }^{67} \pi / \pi$ shifts are common in rabbinic literature in general, ${ }^{68}$ and in Greek transcriptions in rabbinic texts in particular. ${ }^{69}$

66Sperber 1984:163 apparently agrees with Krauss. See also Wasserstein 1993:206207. But see Fraenkel 1898:299, who considers the final $*$ or $\pi$ Aramaic endings superimposed on the Greek words.

67Professor S. Friedman suggested to me the following reconstruction of the $\pi / \pi$ shift in our case: Popular orthography did not originally distinguish between and $\Pi$ (cf. the spelling $\pi$ for in the Bar Kochba letters). The distinction between $\pi$ and $\Pi$ was instituted later in standardized, formal script. But this is possible only when the etymology of the word is clear. In cases such as ours, where the etymology was unknown to the scribes, the popular spelling was preserved (for similar phenomena, see Friedman 1991:72, note 6, and 109-110; Friedman 1992:327-345). In our case, the spelling pas deliberately avoided by the scribes in order to prevent confusion with the homograph meaning "buys;" moreover, the substitute vow formulae were perceived as esoteric, and the more exotic spelling map was naturally preferred.

${ }^{68}$ See Epstein 1948:1232-1233.

${ }^{69}$ See Krauss, 1898-99, volume 1:61. 


\section{SHEVUAH: Taking the Name of the Lord}

\section{[1] The Biblical Executor-Type Oath Formula}

As we have seen in Chapter One, ${ }^{1}$ an oath is a curse to which the swearer subjects himself in the event that his words prove false: in a future-tense oath, the curse is to take effect if and when the oath is violated; in a past-tense oath, the curse is to take effect if the statement made is untrue. The curse itself can either be explicit or implicit, as the following examples indicate: "If I forget you, O Jerusalem, let my right hand wither" (Psalm 137:5); "So shall God do to me and more, also, if..." (I Samuel 25:22); "Annihilation ${ }^{2}$ is mine, if I should do so..." (Genesis 44:17). ${ }^{3}$

In the most common oath formula in the Bible, however, the curse is neither mentioned explicitly nor implied with the phrase "so...and more." Instead, God's name or another noun or pronoun is invoked with the formula חי פלוני or "The Lord lives" or "the life of [the soul of] soand-so," ${ }^{\prime 4}$ where so-and-so is either a divinity ${ }^{5}$ or the person to whom the

\footnotetext{
${ }^{1}$ See above, Chapter 1 , section 1 .

${ }^{2}$ For this interpretation of the Hebrew חלילה, see Lehmann 1969:81.

${ }^{3}$ The body of the oath, which usually follows these formulations, consists of either a direct statement or a conditional clause. See Segal 1928-1929:219-224, Lehmann 1969:86-91, Loewenstamm 1976:481-483, and Azar 1981:11-38, and literature and references cited there.

"The formula ' Lord lives, so shall I do such-and-such." However, this translation is untenable. See Pedersen 1914:141, Tur-Sinai 1956:177-178, Greenberg 1957:36, Loewenstamm 1976:484-485. See also note 21 below.

${ }^{5}$ The formula "the life of...," $\pi$, is never used of God. In Amos 8:14 it is used of false gods, and in Genesis 42:15,16, Joseph invokes פרעה, "the life of Pharaoh," presumably referring to Pharaoh as a divinity. See also Kutscher
} 
oath is addressed. The centrality of the 1 formula is attested by the fact that swearing is often referred to as "taking the name of the Lord," and indeed, Deuteronomy 6:13 and Deuteronomy 10:20 enjoin that the oath formula invoking God's name be used exclusively.

Scholars are divided as to the significance of this oath terminology. M.Z. Segal distinguishes between the formula 'חי הי הי וn in which vocalized as the participle $h a i$, and the formula vocalized as the noun $h e$. Segal asserts that in the formula ' lives"), God is invoked as executor of the oath ("The Lord lives to punish me if I speak falsely or violate my oath"), while in the formula פי ("the life of so-and-so"), the life of so-and-so is offered as surety for the execution of the oath ("If I speak falsely or violate my oath, may the life of so-and-so be forfeit"). However, since in the vast majority of cases soand-so is the addressee of the oath, and it hardly makes sense for the swearer to offer the life of the addressee as surety for the truth of the oath, Segal posits that this is an example of what the Rabbis called תולה קללתו באחרים, transference of a self-imposed curse onto others. ${ }^{6}$ The original oath was חי נפשי, "the life of my soul [is forfeit if the oath proves false]," but because even conditional self-cursing was avoided, this phrase was replaced by חי נפשך, "[I swear on] the life of your soul," or פלוני פלי פלוני in the addressee of the oath, rather than the swearer himself. $^{7}$

Most scholars, however, reject the distinction Segal proposes between the חי פלוני formula, on the grounds that hai and he are spelled the same way in consonantal Hebrew, and the difference in vocalization is probably a mere Masoretic nicety. ${ }^{8}$ According to these scholars, it would be too great a coincidence if the particle referred to a life given as a surety for an oath, while the particle in $\pi$ in referred to the Lord as executor of the oath, who lives to punish its violator. These scholars therefore propose either that both formulations are executor-type oaths, or that both are surety-type oaths.

1970:460-461, who reads פרעה as an invocation of the Egyptian god Re. According to a rabbinic tradition, Joseph intentionally invoked Pharaoh as a false god when swearing falsely. See note 89 below, and reference cited there.

${ }^{6}$ For this phrase in rabbinic literature, see BT Sotah 11a and parallels, referring to Exodus 1:10.

${ }^{7}$ Compare the rabbinic oath formula חיי as a response to the adjuration הישבע לי בחייך, "swear to me on your life." See below, section 4 .

${ }^{8}$ See references cited by Greenberg 1957:36, note 9 . But see below, note 15 . 
N. H. Tur-Sinai, ${ }^{9}$ followed by S. Loewenstamm, ${ }^{10}$ proposes that both

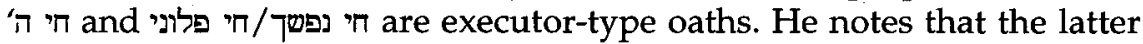
formula is used almost exclusively in cases in which the addressee of the oath is a king or another authority figure. In such cases, the king, like God, is appointed executor of the oath; it is up to him to determine the appropriate punishment if the oath proves false or unfulfilled.

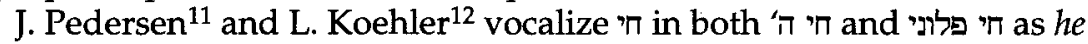
("the life of the Lord" and "the life of so-and-so"), asserting that both are surety-type oaths. The life of either God or the addressee is offered as surety for the fulfillment/truth of the oath. Koehler understands both literally, assuming that God and/or the addressee are dear to the swearer and therefore their deaths can be considered a sanction - despite the obviously problematic reference to the "death" of God. ${ }^{13}$ Pedersen, on the other hand, says that in both cases the sanction is that the life of the Lord or the addressee would be "lost" to the swearer; it is the swearer's relationship with God or the king/authority figure to whom he is swearing that will be cut off. ${ }^{14}$

Of these three views, only that of Tur-Sinai and Loewenstamm seems tenable. Although there is evidence that the hai/he distinction is not merely a Masoretic nicety, ${ }^{15}$ there is no evidence whatsoever for Segal's assertion that חי ופשי חי הדוני המלך is a modification and that the intention is to make one's own life a surety for the truth of the oath. Segal's view is influenced by rabbinic usage, in which חיי" ("by your life") is indeed a substitute for "ח ("by my life"). ${ }^{16}$ But the "original" formula חי נישטי nowhere attested in the Bible, and the notion of projecting a self-imposed curse onto others is a rabbinic midrashic

\footnotetext{
${ }^{9}$ See Tur-Sinai 1956:185.

${ }^{10}$ See Loewenstamm 1976:484.

${ }^{11}$ See Pedersen 1914:141-142.

12 See Koehler 1928:51.

${ }^{13}$ See Greenberg 1957:37, note 18, and Loewenstamm 1976:484, who call this notion blasphemous. But $\mathrm{cf}$. immediately below.

14"Ich bin von dir geloest, wenn...." See Pedersen 1914:141. According to Pedersen, an oath by God is in effect an acknowledgment that the existence of the swearer is dependent upon God (1914:142).

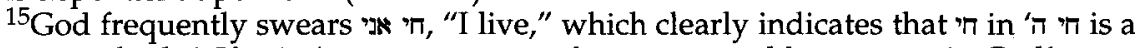
participle, hai. If ח ח ח $\pi$ in were a noun form, we would expect

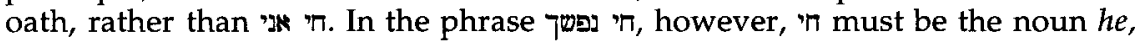
meaning "the life of," since נפש is feminine, and the participial form would thus be חיה נפשך. Nonetheless, both probably mean the same thing: "The Lord lives [to punish me if I do not keep my word/tell the truth]," and "The life of your soul [will make sure that I keep my word/tell the truth]."

${ }^{16}$ See Segal 1928-1929:222-223, and see below, section 4.
} 
concept, and it is doubtful whether it is found in the Bible itself. ${ }^{17}$ Moreover, it is incomprehensible that the swearer would project his curse onto the addressee of the oath, of all people. The addressee, who presumably doubts the truth of the assertion, would hardly consent to have his name invoked in connection with the sanction curse, even as a mere substitute for the name of the swearer. But the fact is that the he formula almost always invokes the addressee, and a powerful addressee at that. In the few cases where a third party is invoked, ${ }^{18}$ the third party is a deity such as Pharaoh or the false god of Dan, hardly an appropriate substitute for the swearer himself. If Segal were correct, we would expect a third party commoner to be invoked at least occasionally, if not exclusively.

Koehler's interpretation is more attractive: God and the addressee are invoked as loved ones, whose lives the swearer agrees to forfeit in case his words prove false. We need not consider this blasphemy; on the contrary, the oath can be understood as follows: "God's/your life is nominally forfeit if I am lying. Since, however, it is both impossible and unthinkable for me to kill God or my beloved king, I had better keep my word." 19 However, this type of oath would only make sense as an extension of a simple surety-type oath, in which the swearer declares forfeit his own life or the life of a loved one over whom he has jurisdiction. In other words, this meaning would only be plausible if we also found surety-type oaths in which the swearer himself or a beloved, mortal, commoner were invoked as surety, and such oaths are nowhere attested in the Bible.

Tur-Sinai and Loewenstamm are thus probably correct. The fact that it is always God, a deity, or a powerful addressee who is invoked in the formula indicates that this type of oath is not a surety formula, but the invocation of an executor. God, a god, and/or the powerful addressee are appointed by the swearer as executors of the oath; the swearer declares that his fate is in the hands of the executor should his words prove false. This type of oath is not really all that different from the curse type: in both cases the swearer curses himself conditionally. However, in the curse-type oath the curse is mentioned or implied, while the agent of the curse is not necessarily mentioned; in the executor type of oath the agent of sanction is mentioned, but the precise sanction is left

\footnotetext{
${ }^{17}$ The Rabbis find biblical precedent for this notion in Exodus 1:10; later rabbinic commentators applied the notion to Numbers $16: 14$ as well. See rabbinic commentaries ad loc. and reference cited above, note 6 . But modern commentators tend to interpret these verses otherwise. See, inter alia, Childs 1974:15 on Exodus and Noth 1968:125-126 on Numbers.

${ }^{18}$ See citations above, note 5 .

${ }^{19} \mathrm{Cf}$. the Egyptian oaths cited below, note 22.
} 
up to him. ${ }^{20}$ Biblical oaths are thus either of the executor type or the curse type. Surety-type oaths are nowhere found in the Bible.

\section{[2] Divine and Human Executors}

Tur-Sinai and Loewenstamm's interpretation of the biblical $\pi$ formula dovetails nicely with the evidence of other ancient Near Eastern cultures. Both ancient Egyptian and Mesopotamian oath formulae are of the executor type. The ancient Egyptian oath formula was " $n h \mathrm{X} n . i$, "soand-so lives for me," where so-and-so is the name of a god. ${ }^{21}$ The phrase "for me" in this formula clearly indicates that the god lives to execute the curse in case the oath is violated. ${ }^{22}$

The Akkadian oath formula is niš X, "so-and-so lives," where soand-so is either a god, the king, or "the city." In Akkadian, only a god is invoked in past-tense oaths, but in future-tense oaths the king or "the city" is sometimes substituted for the name of a deity. This clearly indicates that the entity invoked is executor of the oath: Only a god can take action against someone who swears a past-tense oath falsely, since mortals may never learn the truth. On the other hand, the king or the city officials can be appointed executors of a future-tense commitment, responsible for deciding the fate of the swearer if he violates or does not fulfill his oath. ${ }^{23}$

In biblical Israel, either $\mathrm{God}^{24}$ or the addressee of the oath or both are appointed executors of the oath. If the addressee is appointed executor, he is always a person of some power or authority: a king (I Samuel 17:55, inter alia), a priest (I Samuel 1:26), the king's son (I Samuel 20:3), a rebel

\footnotetext{
${ }^{20}$ Some anthropologists believe that the earliest oaths invoked curses directly, and only later were the gods called upon as agents of punishment. See Crawley 1917:430-433.

${ }^{21}$ See Wilson 1948:129-156 and oaths cited there. Wilson translates "As so-and-so lives for me" (p. 130 and passim), but the word "as" is not found in the Egyptian (cf. Lehmann 1969:85 and Kutscher 1970:460). Wilson is influenced by a once common translation of $A$ in the Bible, for which see above, note 4 .

${ }^{22}$ Occasionally, the name of the god itself is left out, but the context indicates that the reference is to a god, or else that "lives for me" has come to mean simply "I swear." See Wilson 1948:132. Some Egyptian oaths indicate that the formula is not merely an invocation of an executor. Thus Thutmose III swears "...lives for me; Re loves me; my father Amon favors me; my nostrils are rejuvenated with life and satisfaction; I have done these things." This and other similar oaths cited by Wilson, loc. cit., would indicate that the Egyptian formula is a combined executor and surety formula: If I have done things as I claim, then Re lives for me and loves me, Amon favors me, and my nostrils are rejuvenated. The implication is that if I am lying, none of the above are or will be true.

${ }^{23}$ See San Nicolo 1938:305-307 (Reallexikon fuer Assyrologie, s.v. "Eid").

${ }^{24}$ Or a god. See above, note 5 .
} 
leader and future king (I Samuel 25:26), or a prophet (II Kings 2:2, 4, 6; 4:30).

Placing one's fate in the hands of God in case of perjury can properly be called a conditional self-imposed curse; when a human executor is appointed, the oath is not exactly a conditional curse, but a conditional sanction. The swearer forfeits his life or fate to the recipient in the event of falsehood, as in the Second Temple herem..$^{25}$ An oath of this type is a herem without the sacrificial connotation ascribed to the slaughter; the executor's right to punish the swearer is not based upon a previous selfimposed sacrifice, but is rather inherent in the relationship between the swearer and the executor-addressee. The latter is always in a position of authority vis-a-vis the former.

In this light, perhaps certain biblical promises backed up by conditional sanctions should be viewed as curse-type oaths. When Reuben promises to bring Benjamin back to Jacob, he says "You shall slay my two sons, if I bring him not to you" (Genesis 42:37), and when Judah promises the same, he says "if I bring him not to you, let me bear my father's blame forever" (Genesis 43:9). Similarly, David and Absalom back up their assertions of good intent to Jonathan and Joab, respectively, with the statement "if there be in me iniquity, slay me" (I Samuel 20:8; II Samuel 14:32). These are not normally considered oaths, since no supernatural curse is invoked. However, in view of the fact that an executor-type oath can have either a divine or a human executor, it stands to reason that a sanction-type oath need not call upon the head of the swearer a divine curse; a conditionally imposed human sanction can also be considered an oath.

\section{[3] Ancient Greek Oath Formulae}

The vast majority of ancient Greek oaths are likewise of the executor type. A god or another power is invoked with the particle ma or ne, which functions in a manner similar to the Hebrew יח, Egyptian ' $n h$, and Akkadian niš, although the Greek particles are unrelated to the verb "to live." ${ }^{26}$ However, Greek oaths do at times cite a specific sanction or curse, instead of or in addition to the invocation of the deity, just like in the Bible. Lysias writes as follows: "When he had sworn, invoking annihilation on himself and his children...;"27 Demosthenes writes of one who swears "on (kata) his children," presumably referring to a similar oath. ${ }^{28}$ But a surety is never invoked in Greek literature with the

\footnotetext{
${ }^{25}$ See above, Chapter 3.

${ }^{26}$ See Liddell and Scott, s.v. ma and ne.

${ }^{27}$ Lysias, Eratosthenes xii, 10.

${ }^{28}$ Demosthenes, De Falsa Legatione, 292.
} 
prepositions ma or ne. The Greeks, like the ancient Israelites, had cursetype oaths and executor-type oaths, but no surety-type oaths in which the surety's name is invoked without further clarification. ${ }^{29}$

Although the vast majority of Greek oaths are executor-type oaths invoking the gods, the Greeks were often reluctant to appoint deities explicitly as executors of their oaths. They therefore substituted simple nouns such as "dog," "goose," "plane tree," and various vegetables for the names of the gods. ${ }^{30}$ According to some scholars, the first replacement nouns rhymed or sounded like the names of various gods; $; 1$ only at a later stage did they begin to use any noun as a substitute for the deity. An oath in which a common noun is used instead of the name of a god is termed rhadamanthuos horkos, a rhadamanthian oath, after the legendary king Rhadamanthys of Crete who is supposed to have ordered his subjects to refrain from swearing by the gods themselves. ${ }^{32}$

\footnotetext{
${ }^{29}$ In some oath formulae it is unclear whether the person invoked is invoked as executor or as surety; however, Lidell and Scott understand all of these cases to be executor-type oaths. Helen in Euripides' Helen swears to her husband, the king Menelaeus, by his head, to kill herself if he dies: hagnon horkon son kara katomosa (l. 835). If he is dead, he is in no position to act as either executor or surety, but clearly one or the other is intended. However, Lidell and Scott, s.v. katomnumi, define the verb "call to witness, swear by," thus making it clear that in their view, at least, in this and other cases in which katomnumi is used, the entity invoked is an executor. In a fragment from Callimachus' Lock of Berenice, a lock of Queen Berenice's hair swears to her that it was cut off of her head against its will: "I swear by your head and by your life," sen te karen omosa son te bion (fragment 3). From the fragment itself it is unclear whether the beloved queen is invoked as a surety for the truth of the statement, or whether she is appointed executor of the oath. However, Catullus' Latin translation preserves the end of the oath, which makes it clear that Berenice is invoked as executor: "I swear by both you and your head, by which, if any swear vainly, let him reap a worthy recompense" (Catullus 66). Since the recompense is to be reaped by the swearer himself, it is clear that Berenice and her head are executors, and not sureties. In the Iliad, Hera swears by earth, heaven, "and the dripping water of the Styx, which is the biggest and most formidable oath among the blessed immortals," as well as Zeus' head, and the marriage bed of Hera and Zeus (lliad 15, 37-39). While the last might conceivably be considered a surety, ("let our marriage break up if I am lying"), in context it is clear that all are invoked as deity- or sacred-object-type executors. In ancient Greece, the gods alone took oaths by sacred objects such as the Styx and their own marriage bed; mortals always invoked the gods as executors. See Liddell and Scott, s.v. horkos.

${ }^{30}$ See Cratinus (ed. Kock), fragment 231; Sosicrates in Jacoby, Fragmente der griechische Historiker, 461, fragment 3; the scholia to Plato's Apology 22a, Republic 398e, and Phaedrus 228b; Zenobius v, 81; Philostratus, Vita Apollonius vi; and Lieberman 1942:125-128 and citations there.

${ }^{31}$ See Kock's commentary to Aristophanes' Birds, 1. 521.

${ }^{32}$ Sosicrates (see above, note 30 ).
} 
S. Lieberman understands much rabbinic oath terminology in light of this classical Greek usage. In his chapter on oaths and vows in his book Greek in Jewish Palestine, Lieberman cites three types of rabbinic oaths which in his view echo the Greek practice of using substitutes for the divine name in oaths.

The first category of oaths cited by Lieberman are oaths בחיי פלוני: "by the life of my/your head,"33 "by the life of the fig-picker," 34 "by the life of my son," 35 and "by the life of the king." ${ }^{36}$ This type of oath, often referred to inexactly as a neder in rabbinic literature, is actually a substitution oath of the Greek type, according to Lieberman. ${ }^{37}$ According to Sifre Bemidbar 153, an oath proper is tantamount to an oath by the king himself, while a neder (in the sense of substitute oath) is like an oath by the life of the king. ${ }^{38}$ In fact, the Romans distinguished between oaths by the genius (or divinity) of the emperor and oaths by his welfare and safety. ${ }^{39}$ Lieberman is uncertain of the practical difference between these two types of oaths. He sees both of these as executor-type oaths, but the latter is limited in that it is connected with the life-span of an individual. Thus an oath by the life of the emperor is a rhadamanthian substitute for an oath by the emperor himself as divinity, ${ }^{40}$ and presumably the rabbinic oaths "by the life of my head," "by the life of my son," "by the life of the fig-picker," 41 are likewise substitutes for oaths "by God."

The second category of oaths cited by Lieberman are oaths by ordinary objects lacking any sanctity, true rhadamanthian oaths. Lieberman cites only one example of this in rabbinic literature: the reference in Mishnah Nedarim 2:5 to one who vows a herem and then claims to have been swearing or vowing by the herem of the sea (=fishnet). Lieberman cites the use of "fishnets" as a rhadamanthian substitute in a play by Aristophanes, ${ }^{42}$ and cites the Mishnah as evidence that such oaths were current in Jewish Palestine. ${ }^{43}$

\footnotetext{
${ }^{33}$ Mishnah Sanhedrin 3:2, Tosefta Sanhedrin 5:1.

${ }^{34}$ Tosefta Sanhedrin 5:1.

${ }^{35}$ Mekhilta Pisha, paragraph 16.

${ }^{36}$ Tosefta Sotah 6:1, Sifre Bemidbar 153.

${ }^{37}$ Lieberman 1942:115, 119.

38 See below, section 7 .

${ }^{39}$ See Lieberman 1942:118-119 and literature cited there. But see below, section 6 .

${ }^{40}$ Lieberman 1942:119.

${ }^{41}$ Lieberman 1942:127-128, but see note 99 there, and note 43 below.

${ }^{42}$ Aristophanes, Birds, 1. 194.

${ }^{43}$ Similarly, Lieberman suggests in a footnote that perhaps "by the life of the figs" should be read in Tosefta Sanhedrin 5:1 instead of "by the life of the fig-picker," in which case it would be an example of a true rhadamanthian vegetable oath. But see below, note 53 .
} 
Finally, Lieberman considers oaths by an offering, by Jerusalem, by the altar, by the ram, and the like, which for the most part are considered unacceptable according to tannaitic law, ${ }^{44}$ to be popular oaths by substitutes for the divine name current in Jewish Palestine. ${ }^{45}$

\section{[4] The Greek Model Cannot Explain Rabbinic Usage}

Analysis of each of these categories, however, indicates that the Greek model is inappropriate and insufficient to explain the rabbinic usage. An oath by the life of one's head or by the life of one's son can hardly be considered an executor-type oath, in which one's own life or the life of one's son is used as a divinity substitute. Rabbinic literature is replete with the adjuration $2,{ }^{46}$ or simply $7{ }^{4},{ }^{47}$ "[swear to me on] your life," and it is clear that in these cases the swearer is asked to put his own life on the line as surety for the truth of his statement. Surprisingly, $ך$ י" is used not only as an adjuration ("Swear to me on your life"), but also very frequently as an oath ("II swear on] your life").48 This is apparently a projection of ${ }^{\prime}$ onto the addressee, in keeping with the rabbinic practice of not cursing oneself explicitly. ${ }^{49}$ Although we rejected Segal's theory that the biblical $\pi$ is a projection of a self-imprecation onto the addressee, ${ }^{50}$ it would seem clear that the rabbinic ${ }^{2}$ oath should be understood thus, since virtually every adjuration imposed by another of this type has בחייך (implying the oath בחיי), but virtually every oath has

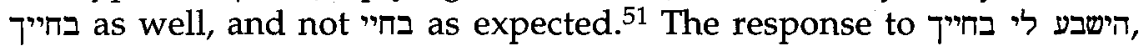

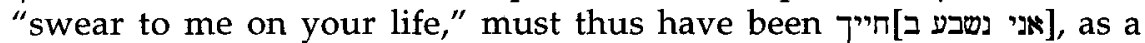

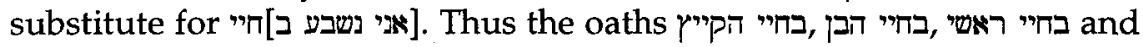
are not rhadamanthian type oaths in which the divine name is replaced with these terms, but surety-type oaths like חייך, in which these lives are made surety for the truth of the oath.

There is likewise no hard evidence for true rhadamanthian oaths in rabbinic literature. The only example of the use of ordinary objects in

\footnotetext{
${ }^{44}$ See Mishnah Nedarim 1:3-4, Tosefta Nedarim 1:2.

${ }^{45}$ Lieberman 1942:129-139.

${ }^{46}$ See Mishnah Sanhedrin 3:2, Tosefta Sanhedrin 5:1, Numbers Rabbah 2, Deuteronomy Rabbah 1, and other citations in the Ben-Yehudah Dictionary, volume 3:1520, s.v. $\pi$.

${ }^{47}$ See references and citations in Tur-Sinai 1956:185; the Ben-Yehudah Dictionary, volume 3:1517, s.v. $\pi$.

${ }^{48}$ See citations in the Ben-Yehudah Dictionary, volume 3:1517-1520, s.v. $\pi$.

${ }^{49}$ See above, notes 6 and 17.

50 See above, section 1 .

${ }^{51}$ See also Tur-Sinai 1956:186. His explanation, however, that the oath as a divine oath meaning "your life is my hands" is rather far-fetched. This sounds like a threat, and thus would be inappropriate in a divine promise of reward.
} 
rabbinic oath formulae cited by Lieberman is Mishnah Nedarim 2:5, which reads as follows:

If one vows a herem and then says "I was only swearing by a fishnet [herem]...the Rabbis say that we try to release him from his vow on other grounds, and we instruct him not to act light-heartedly with respect to vows. .52

This text is best understood in its plain sense: the votary vowed a herem and then claims to have been facetiously vowing by a fishnet. There is no evidence whatsoever that such an oath or vow was taken seriously by the Jews of Palestine. On the contrary, the mishnaic usage makes it clear that the votary could not imagine anyone taking a vow by a fishnet seriously, and therefore he wishes to avoid being bound by the herem. It is true that PT tells of a man who actually claimed to have been swearing by a fishnet under these circumstances; however, this hardly indicates that the word herem was used in rhadamanthian oaths in the sense of "fishnet." The man improvised this explanation in order to renege upon his vow. 53

The third category of oaths cited by Lieberman, oaths by the offering, by the Temple, by Jerusalem, by the ram, and the like, are oaths by sacred objects. These oaths are not substitute formulae of any kind: the sacred object itself is thought to have the magical power to bring about a curse in the event of perjury. This type of oath was common in many ancient cultures, ${ }^{54}$ but is quite rare in Greek or Hellenistic culture. ${ }^{55}$ For the most part, the Rabbis forbade the use of such oaths; ${ }^{56}$ the people nevertheless

\footnotetext{
${ }^{52} \mathrm{PT}$ Nedarim 2:5, 37c. The Talmud states that a single person vowed all the vows and made all the claims of facetiousness mentioned in Mishnah Nedarim 2:5. Thus, even if we were to consider the story historical, it would hardly indicate that the oath "by the fishnet" was common in Palestine, pace Lieberman 1942:128. ${ }^{53}$ The only other such oath cited by Lieberman, the oath "by the life of the figs," בחיי הקיץ, is an alternate vocalization of an oath cited in Tosefta Sanhedrin 5:1 (see below, section 6). Lieberman cites this vocalization as a possibility only, in a footnote (Lieberman 1942:128, note 99). The context, however, clearly indicates that the reading בחיי הקי"ץ, "by the life of the fig-picker," is to be preferred. The oath in the Tosefta is prompted by the adjuration "Vow to me by the life of your head." It would thus seem that the swearer himself was a fig-picker, or else he transferred his own curse onto the head of the fig-picker.

${ }^{54}$ See Crawley 1917:431-432.

${ }^{55}$ Only the gods swore by objects, rather than gods, in ancient Greece. See above, note 29. But cf. also the scholion to Aristophanes' Birds, 1. 521, where it is asserted, apparently erroneously, that the rhadamanthian oath "by the goose" is an oath by a sacred object used in augury.

${ }^{56}$ See above, notes 44 and 45 .
} 
continued to use such formulations, ${ }^{57}$ and some of them were sanctioned by some of the Rabbis. ${ }^{58}$

\section{[5] Roman Oath Types and Rabbinic Usage}

Lieberman's attempt to connect these three oath types with Greek cultural influences is thus doubtful. Nonetheless, the question must be asked: How did these rabbinic oath formulae develop? How is it that surety-type oaths by the life of the swearer or a substitute (" $T$ " $T$ ") are so common in rabbinic literature, when these are unattested in the Bible, in the ancient Near East, and in Greece? Moreover, how did the formula חיי פלוני, so similar to the biblical formula חי פלוני, develop in rabbinic Hebrew with so different a meaning? And how did the custom of swearing by sacred objects, which is hardly known in ancient Israel or Greece, develop in Jewish Palestine of the rabbinic era?

The answers lie in the influence of another culture, that of Rome. These oath types are Roman oath types, poorly understood in the Eastern empire, ${ }^{59}$ but nonetheless quite common.

In addition to simple executor-type oaths by the gods, classical Latin authors often refer to surety-type oaths invoking the swearer himself and his loved ones, and even a beloved addressee; executor-type oaths invoking the spirits of the dead; and sacred-object-type executor oaths, in which an object is deemed capable of wreaking vengeance on the perjurer ${ }^{60}$ These types of oaths are used interchangeably; occasionally, a single oath will mix the various types. In all types of Roman oaths: divine executor oaths, surety-type oaths, executor-type oaths invoking spirits, and executor-type oaths involving sacred objects, the noun, proper noun, or pronoun is introduced by the preposition per. Thus Horace refers to an oath by (per) the swearer's head (surety-type), ${ }^{61}$ Pliny the Younger refers to "the worse than perjury of a man who swears a false oath on (per) the life his son...calling down the wrath of the gods on the head of his unfortunate son" (surety-type), ${ }^{62}$ while Juvenal refers to the lying Greeks who swear an oath on (per) someone else's head (surety-

\footnotetext{
${ }^{57}$ Lieberman 1942:130-131.

${ }^{58}$ See above, Chapter 1 , note 38 .

${ }^{59}$ See references to Philo and Athanaeus of Nacritus below, section 6 .

${ }^{60} \mathrm{In}$ addition to the references cited below, see summary and classification of Roman oaths in Smith 1890, s.v. jusjurandum.

${ }^{61}$ Odes 2,8,5-6.

${ }^{62}$ Epistles II, 20.
} 
type). ${ }^{63}$ Juvenal also refers to an oath by (per) the gods' weapons, ${ }^{64}$ clearly not a surety oath but a sacred-object-type oath. That same oath also contains a curse called down upon the life of the swearer's son. ${ }^{65}$ Ovid cites the following oath: "Yet you had sworn that you would ever be comerade of mine, by me and by your eyes." ${ }^{\prime 66}$ In this case it would seem that both the swearer's eyes and the addressee are invoked as sureties, though the addressee may be an executor. Similar is the following citation, also from Ovid: "swearing it by his own head and by thine, which I know he counts not cheaper than his own." ${ }^{167}$ In this case it is clear that both the swearer and his beloved are sureties. Virgil ${ }^{68}$ and Silius Italicus ${ }^{69}$ refer to Aeneas' oaths by (per) the head of his son, and, according to Virgil, Aeneas' son, Ascanius, continued to swear by his own head, by which his father used to swear. ${ }^{70}$

Often a single oath will contain a list of two or even all three types of nouns: sureties, sacred objects, and executors. For example, in the following citation from Martial, a sacred object is cited along with a surety: "You swore by your sacred rites and by your head."71 In two other oaths cited by Ovid, sacred objects, beloved sureties, and executors are invoked side by side:

By my weapons, the torch and arms, by my mother, and by Caesar's head.... ${ }^{72}$

By the bones of my wedded lord, bones ever to be held sacred in my eyes, and by the brave souls of my three brothers, now spirits divine...and by your head and mine, which we have laid each to each, and by your sword.... ${ }^{73}$

It is thus Roman culture, not Greek, that influenced popular oath formulae in Jewish Palestine. Adjurations such as "vow/swear to me on your life," and the corresponding oath 7 , "by your (i.e. my) life;" oaths by "the life of my head," "the life of my son," "the life of the fig-picker" and the "life of the king" are surety-type oaths invoking the swearer

\footnotetext{
${ }^{63}$ Juvenal VI, 16. The reference to the Greeks in no way indicates that Juvenal actually knew of Greek oaths of this type. The Greeks are cited as notorious liars, who would use any trick to lie safely under oath. See commentaries, ad loc.

64Juvenal XIII, 77-83.

${ }^{65}$ Juvenal XIII, 84-85.

${ }^{66}$ Amores II, 16, 44.

${ }^{67}$ Tristia $\mathrm{V}, \mathrm{iv}, 45$.

${ }^{68}$ See Pease $1935: 310$ to Aeneid 4:357.

${ }^{69}$ Silius Italicus 8:106.

${ }^{70}$ Aeneid 9:300.

${ }^{71}$ Martial IX, 48, 2.

${ }^{72}$ Ex Ponto 3, 3, 68.

${ }^{73}$ Heroides III, 103-110.
} 
himself or those he loves, common in Roman literature but rare or nonexistent in Greek. ${ }^{74}$ Similarly, oaths invoking sacred objects are common in Roman sources but not in Greek. ${ }^{75}$ On the other hand, the Greek custom of substituting an ordinary noun for the name of the divine executor in an oath is not attested in rabbinic literature.

\section{[6] Further Examples of Roman Influence}

Other Palestinian sources cited by Lieberman should likewise be understood in light of Roman, rather than Greek, usage. Matthew 5:36 is cited by Lieberman ${ }^{76}$ as an example of an oath in which a profane (not sacred) object ("the head") replaces the name of God:

And do not swear by your head, for you cannot make one hair white or black.

But the head here is clearly a surety. Jesus mocks the custom of swearing on one's head, since the curse is ineffective.

In Midrash Shir Hashirim Rabbah 2:7 the adjuration of the daughters of Jerusalem by the ("deer") and the ("gazelles") (Song of Songs 2:7) is variously interpreted:

By what did he adjure them? Rabbi Eliezer says by heaven and earth ("the hosts," צבאות, of heaven and earth)...the gazelles, these are the beasts of the field...

Rabbi Hanina bar Papa says by the Patriarchs and Matriarchs, who did my will (צביוני)...

Rabbi Judah ben Simon says by the circumcised host (צבא שיש בו אות), whose blood is shed like that of deer and gazelles...

The Rabbis say by the generation of [the Hadrianic] persecution, who did my will (צביוני (צn and shed their own blood like the deer and the gazelle on my account.

Lieberman understands all of the above as divinity substitutes. ${ }^{77}$ But these are hardly akin to the Greek rhadamanthian substitutes. Heaven and earth and the beasts of the field are invoked as executors in their own right, elements of nature that are called upon to wreak vengeance upon the perjurer (cf. our colloquial "May lightning strike me if..."), in a manner similar to that of the Roman oath by the gods' weapons ${ }^{78}$ or by the sacred land..$^{79}$ The Patriarchs and Matriarchs are also executors,

${ }^{74}$ See above, notes $27-29$.

${ }^{75}$ See above, notes 29 and 55 .

76Lieberman 1942:137, note 163 .

77 Lieberman 1942:124, note 77 .

78Juvenal XIII, 77-83.

${ }^{79}$ Silius Italicus 8:106. 
invoked in a manner similar to "the souls of my three brothers, now spirits divine" in a Roman oath. ${ }^{80}$ On the other hand, the circumcised host (Israel), and more specifically the Jews of Hadrian's time, are invoked as sureties: if the oath is fulfilled, the Jews will live; if not, they will die, as they did under Hadrian. ${ }^{81}$

There is one Jewish source, however, which does seem to indicate that Jews used oath substitutes in order to avoid using God's name, in a manner similar to that of the Greek rhadamanthian oath. This is Philo's discourse on oaths, in which he expresses a preference for oaths which avoid mention of God's name. Philo writes as follows:

And if indeed occasion should force us to swear, the oath should be by a father and mother, their good health and welfare if they are alive, their memory if they are dead. For parents are copies and likenesses of the divine power, since they have brought the nonexistent into existence. In the laws we read of one of our first founders, who are particularly admired for their wisdom, that he swore by the fear of his father.... 82

but also a person may add to his ma or ne, if he wish, not the highest and most venerable and primal cause, but earth, sun, stars, heaven, the whole universe. For these are worthy of highest respect....83

Philo clearly interprets the oaths common in his time as rhadamanthian oaths. The beings and objects invoked are substitutes for the divine name, and not sureties for the truth of the oath. Philo insists that in contradistinction to the Greek practice, the Jew use substitutes which are objects of veneration in their own right, rather than mere common nouns.

However, it is likely that Philo is merely interpreting the common Roman practice of his day in light of Greek usage. The oaths cited were originally executor-, surety- and sacred-object-type oaths, common in Roman practice. It is Philo who reinterprets them as divinity-substitute oaths. The health and welfare of the swearer's parents were clearly invoked as sureties, not as objects of respect cited as executors or substitutes for the divine name. If Philo (and Lieberman) were correct,

\footnotetext{
${ }^{80}$ Ovid, Heroides III, 103-110.

${ }^{81}$ Lieberman 1942:125, note 77, also cites IV Maccabees 10:15, “By the blessed death of my brothers, by the everlasting destruction of the tyrant...." These may in fact be Philonic type rhadamanthian oaths by "things worthy of the highest respect" (see immediately below), as suggested by Lieberman, but they may also be oaths by abstract "sacred objects." Cf. Hera's oath by her marriage bed (Iliad 15:37-39), clearly meant to symbolize her sacred marriage itself, and Aeneas' oath "by this sacred land" (Silius Italicus 8:106).

${ }^{82}$ Philo, de Specialibus Legibus II, 2.

${ }^{83}$ Philo, de Specialibus Legibus II, 5.
} 
we would have expected the parents themselves to be invoked, and not their health and welfare. It may be that the memory of the parents is a type of divinity substitute, or alternate executor, akin to the "brave souls of my three brothers, now spirits divine," although it is also possible that the memory of the parents is invoked as surety: if I speak falsehood, may the memory of my parents be blotted out. On the other hand, heaven and earth, the sun, the stars, and the cosmos could hardly be considered by a religious Jew substitutes for the divine name. The natural elements themselves are called upon to punish the offending perjurer, as we saw in Roman literature. These types of oaths are typical of Roman culture, as we have seen.

Philo's misunderstanding of Roman oaths is typical of that of the Hellenistic writers of Roman Egypt. Thus Athenaeus of Nacritus, a thirdcentury C.E. Greek writer of Egyptian origin living in Rome, writes: "That people regarded the head as sacred is clear from the fact that they swore by it," 84 even though it is clear that when human heads are invoked in Roman oaths, they are invoked as sureties, and not as sacred executors.

A striking parallel to Mishnah Sanhedrin 3:2 and Tosefta Sanhedrin 5:1, cited by Lieberman as examples of rabbinic substitute oath formulae, is found in Roman law. Mishnah Sanhedrin 3:2 reads as follows:

If someone was obligated to swear to his fellow, and the fellow said to him "Vow [i.e. swear] to me [instead] by the life of your head," he can retract his statement....

The Tosefta further clarifies:

And thus said Rabbi Judah: Whoever was obligated to swear to his fellow in court, and the fellow said to him "Vow to me by the life of your head," and he agreed, cannot retract. And it happened that someone who was obligated to swear to his fellow in court vowed to him by the life of the fig-picker, and he accepted the oath.

As we have seen above, Lieberman considers the vows "by the life of my head" and "by the life of the fig-picker" substitutes for oaths "by God." In fact, however, we have shown that these are not mere substitutes, but a different sort of oath entirely. Instead of invoking God as executor of the oath, a human life is submitted as surety for the truth of the oath. This very situation is described clearly in the Digest of Justinian, in the name of the jurists Ulpian and Paul:

An oath ought to be sworn just as it is tendered. In the other case, as where I tender you an oath by a god and you swear on your head, or on that of your sons, the oath is not to be held good. Yet if I tell

${ }^{84}$ Athenaeus of Nacritus 2, 66c. 
you to swear on your salvation (welfare), and you so swear, that will be valid. ${ }^{85}$

The law is identical to that of the Tosefta. Only if the adjurer is willing to accept an oath "on so-and-so's head" is this type of oath acceptable in court. Note that in Latin, as in Hebrew, the same preposition (Latin per, Hebrew b-) is used for oaths "by God" and oaths "on so-and-so's life."

In Roman Egypt we find oaths by the king or emperor, as executor, ${ }^{86}$ side by side with oaths by the life of the king, ${ }^{87}$ as an object of affection whose life would be forfeit in case of a lie. The latter were taken as a token of affection for the king, ${ }^{88}$ although swearing on the king's life could clearly be interpreted otherwise. Thus the Rabbis assert that Joseph intentionally swore two false oaths "by the life of Pharaoh," 89 and Tertullian takes pains to assert that the Christian practice of swearing by the welfare of the emperor is not a Christian trick designed to place the emperor's welfare in jeopardy, but a sign of love for the emperor. ${ }^{90}$ Perhaps it is in this light that Caligula's edict demanding that the people swear by his genius (or "divinity") ${ }^{91}$ should be understood. The people may have been accustomed to swear on the welfare of this unpopular emperor, and Caligula feared that they did so out of disrespect. $\mathrm{He}$ therefore insisted that the name of his genius be invoked as executor, and not as surety. ${ }^{92}$

Lieberman is unsure of "the practical implications of the difference between these two kinds of oaths," oaths by his welfare, since in Lieberman's view the king's welfare is merely a substitute for the king's genius. According to Lieberman, in the latter type the king's divine nature is appointed executor of the oath, while in the former the king's welfare is used as a substitute for his divinity, but in either case the intent is to invoke an executor. However, the fact that Romans had both executor- and surety-type oaths makes the distinction clear: an oath by the king's divinity as executor is a clear sign of respect for the king, with practical implications as far as the

${ }^{85}$ Digesta XII, 3-5.

86 See citations in Lieberman 1942:118; Smith 1890:662-663.

${ }^{87}$ See Smith 1890:663 and citations there; Lieberman 1942:116, note 23.

${ }^{88}$ Tertullian, Apology, XXXII; Tosefta Sotah 6:1. See Lieberman 1942:118-119.

${ }^{89}$ Genesis Rabbah 91.

${ }^{90}$ Tertullian, Apology, XXXII.

${ }^{91}$ Suetonius, Caligula, 27. For the meaning of "genius" in this context, see OCD, s.v. "genius."

${ }^{92} \mathrm{Cf}$. also Tosefta Sotah 6:1: "A person does not swear by the king unless he loves the king." Perhaps this is an example of Jewish apologetic aimed at the Romans, akin to that of Tertullian. In that case, "swear by the king" would mean "swear by the life/welfare of the king," as opposed to his genius or divinity.

${ }^{93}$ Lieberman 1942:118. 
punishment for perjury is concerned. An oath with the king's life or welfare as surety can be a sign of affection for the king, but it can also be a roundabout way of bringing a curse on the king's head, or at least a sign that jeopardizing the king's life is of little consequence to the swearer.

\section{[7] Rabbinic Surety-Type Sanction Oaths and Doubly-Conditional Rabbinic Prohibitive Vows}

Lieberman points out that oaths in which the divine name is "replaced" by another noun are often referred to as neder, rather than shevu ${ }^{\prime} h{ }^{94}$ but he does not clearly explain the reason for this. According to our analysis, the reason is clear. Rabbinic oaths in which names other than that of God are cited are surety-type sanction oaths, rather than executor oaths. As such, they resemble the rabbinic neder, and are therefore easily confused with the rabbinic neder.

In Chapter One, we showed that the rabbinic neder originated as a dedicatory vow which cannot possibly be fulfilled as vowed: If a man says "the food that I eat is qorban," no food is actually given to the Temple, but the man is forbidden to eat. ${ }^{95}$ If he does in fact eat, a sanction ensues automatically: the food he is eating becomes sacred Temple property, and therefore he is guilty of trespass. This type of dedicatory vow thus becomes a substitute for a future-tense oath. Instead of saying: I swear by God that I shall not eat, the votary dedicates the food that he is about to eat to the Temple. The practical difference between the two is this: if he swears by God, God is asked to punish him if he violates his oath; if he dedicates the property to God when and if he eats it, the sanctions that ensue are legal consequences: death or lashing for trespassing upon Temple property intentionally; an asham sacrifice for trespassing unintentionally. ${ }^{96}$

Moreover, the Rabbis found a means by which vows could be substituted not only for future-tense negative oaths, but also for pasttense oaths and future-tense oaths that do not involve derivation of benefit from specific objects. Instead of swearing to his wife "I swear by God that I shall divorce you," a man can say "All the produce in the world is qonam upon me [= all the produce in the world is qorban if I eat it] if I do not divorce you. ${ }^{\prime \prime 7}$ If he takes an oath to divorce his wife, God is called upon to punish him should he fail to do so. If he makes a doubly-conditional neder to divorce his wife, and fails to do so, he is no

\footnotetext{
${ }^{94}$ Lieberman 1942:117-118.

${ }^{95}$ See above, Chapter 1 , section 2.

96 See above, Chapter 1, note 8; Chapter 3, note 43.

${ }^{97}$ Mishnah Gittin 4:8, BT Gittin 46b.
} 
longer permitted to eat agricultural produce. If he does not divorce her and eats agricultural produce, he is liable for trespass against Temple property.

Or take the following example: instead of saying "I swear by God that this produce belongs to the king," a man can vow "My property is qonam upon my wife and children [=my property is qonam if my wife and children make use of it] if this produce does not belong to the king." This doubly-conditional vow dedicates the votary's property to God if and when his family makes use of it, and then only if he is lying about the status of the produce. In effect this is tantamount to swearing that the produce does not belong to the king, since he cannot allow himself to cut his family off from his property either legally or morally. The difference is that if he swears that the produce belongs to the king, God is called upon to punish him if he is lying; if, on the other hand, he makes a conditional dedicatory-prohibitive vow to that effect, the sanction is that his family can no longer derive benefit from his property, and the legal consequences inherent in this fact. The conditional neder is thus very similar to the biblical sanction-type oath "if I forget you, O Jerusalem, let my right hand wither." If the swearer forgets Jerusalem, a consequence spelled out in the oath will ensue. If the votary fails to divorce his wife, he is forbidden to eat produce, as specified in his vow. Both of these can be distinguished from the executor-type oath invoking God. In the latter, the punishment is left up to the executor; in the first two, the punishment is specified by the swearer or votary.

It is no wonder therefore that the verb נis often used with suretytype oaths. These oaths have as much, if not more, in common with rabbinic vows than with classic biblical or rabbinic oaths. The suretytype oath offers the life or welfare of the swearer or his loved one as a surety for the execution of the oath, just as the conditional vow specifies the sanction that will ensue to the votary himself or his loved one if he is lying. It is in this light that we should understand the comment in the Sifre Bemidbar 153:

What is the difference between vows and oaths? Vows are like vowing by the life of the king; oaths are like swearing by the king himself.

Conditional vows are a lot like "vowing" by the life of the king; in both cases an unthinkable sanction, impossible to carry out, is mentioned. Oaths, on the other hand, are invocations of God as executor. As such, they are comparable to the Roman oath by the emperor's "genius" itself.

\footnotetext{
${ }^{98}$ Mishnah Nedarim 3:4. See below, Chapter 6, note 6, and reference cited there.
} 


\section{[8] The Divine Name in Rabbinic Oaths}

One further crux that has plagued Talmud commentators for centuries ${ }^{99}$ can be elucidated on the basis of the distinction between surety-type oaths and executor-type oaths. Mishnah Shevuot 4:13 reads as follows:

[If one swears] "by heaven and earth," he is not liable. "By Adonai," "by YH," "by Shaddai," "by Sebaoth," "by the gracious and merciful one," "by the patient one, most kind," and by all of the divine epithets, he is liable.

The mishnah's insistence upon the use of an actual divine name in an oath is puzzling in light of the oaths cited as halakhic paradigms throughout rabbinic literature, and in Mishnah tractate Shevuot in particular. In halakhic discourse, the oath formula is almost exclusively שבועה ש- followed by a direct statement. Mishnah Shevuot 3:1 lists the four basic types of oaths: future-tense positive, future-tense negative, past-tense positive and past-tense negative. The four classic formulae are all given in terms of the simple oath formula שבועה ש: "shevu ah that I shall eat," "shevi'ah that I shall not eat," "shevu'ah that I have eaten," and "shevu ah that I have not eaten."

On the other hand, the oath formula שבועה ש- is almost never found in citations, whether real or artificial, of rabbinic conversation in rabbinic narrative. ${ }^{100}$ The oaths found in rabbinic dialogue are of various types. We have already noted the common sanction-type oath formula "On your [=my] life that...." We also find the executor formulae 101 and משה. 102

What are we to make of this evidence? One mishnah, Shevuot 4:13, insists that a divine name be cited in an oath, but the usual examples of oaths given in the Mishnah have instead the word shevu ah. In dialogue, by contrast, the shevu'ah formula is never used, and instead we have various formulae: an executor formula citing a divine name, an executor formula citing Moses, and a surety formula, 7 חי

Various possibilities present themselves. The most obvious is that shevi ah is not a genuine oath formula at all, but a rabbinic device to avoid using actual oaths in halakhic discourse, when no actual oath is intended. In practice, Mishnah Shevuot 4:13 insisted upon the use of a

\footnotetext{
${ }^{99}$ See Yaffin-Ritba appendix 1977:23-26.

${ }^{100}$ The only clear example is BT Nedarim 25b, where the formula שבועתא is cited in an amoraic oath. However, this may be a late reworking of a parallel in BT Shevuot 26a, where the oath formula is not mentioned explicitly. See Epstein 1963:62, De Vries 1968:198-199; but see Benovitz 1993:407.

101 See citations above, Chapter 4 , note 16 .

${ }^{102}$ See citations above, Chapter 4, note 19.
} 
divine name, and the word shevi ah used in other examples of oaths merely represents the divine name in halakhic discourse. The people, however, including rabbis, nonetheless used oath formulae such as and משה, in addition to the classic האלהים. These were considered legitimate by some of the Rabbis, although not according to Mishnah Shevuot 4:13.

However, this cannot be the case. Although the use of shevu'ah as an oath formula is nowhere clearly attested in rabbinic dialogue, we do have indirect evidence that shevi'ah was an actual oath formula, and that it was rather common in popular usage. Mishnah Nedarim 1:2, which lists the substitute votive formulae, considers שבוקד, שבותה and an oath "by "פוהי" legitimate oath substitutes. These clearly hark back to the standard formulae shevi ah and "by משה."103

It is therefore clear that when the Mishnah cites the shevu'ah formula in its examples it is not merely using the term shevu'ah as a handy substitute for the divine name, but is reflecting common legitimate practice. Why then does Mishnah Shevuot 4:13 insist upon the use of the divine name?

Some of the medieval commentaries explain that both the word shevi'ah or some other oath formula and the name of God are necessary. ${ }^{104}$ Thus, when the Mishnah speaks of an oath "that I shall eat,"

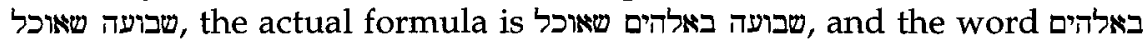
was left out from this and other paradigms in order to avoid the unnecessary use of God's name in halakhic discussion. However, this too is unlikely, for the reason cited above: Mishnah Nedarim 1:2 considers שבותה ,שבוקה and an oath "by Mohi" to be oath substitutes on a par with one another. If שבותה were a substitute for the word shevu'ah in an oath formula, and משה which in turn replaces the divine name, they would hardly have been listed together. Moreover, as we have already mentioned, oaths cited in the course of conversation almost never use the word shevi ah.

The most satisfactory explanation is therefore that of other medieval authorities, who explain that an oath can consist either of the words שבועה ש followed by a direct statement or of a direct statement with the divine name, and both are equally binding. ${ }^{105}$ This is consonant with the evidence presented above, since the word shevu'ah probably originally referred to seven (שבע) curses called down upon the head of the swearer

\footnotetext{
${ }^{103}$ See above, Chapter 4 , section 1 , notes $19-24$.

${ }^{104}$ Maimonides, Mishneh Torah, Shevuot 2:3, inter alia. For detailed survey and analysis of the various medieval views on the subject, see Yaffin-Ritba appendix 1977:23-26.

${ }^{105}$ Rabbenu Nissim to Shevuot 36b, Ritba to Nedarim 2a.
} 
in case he perjures himself. ${ }^{106}$ Like biblical oaths, rabbinic oaths can thus be either executor-type oaths invoking God's name (האלהים) or that of a spirit (משה, מוהי), or curse-type oaths in which the curses are not made explicit (שבועה ש-). In addition, rabbinic literature is replete with suretytype oaths, in which the swearer offers his own life or that of a loved one as surety for the truth of the oath. In rabbinic literature, בחייך or is often used in such oaths instead of בחיי חי חי onto others. ${ }^{107}$

106 See Greenberg 1971:1296.

${ }^{107}$ It is unclear whether one who takes a false surety- or curse- type oath could be considered taking the name of the Lord in vain (Exodus 20:7), or swearing falsely in God's name (Leviticus 19:12). See Yaffin-Ritba appendix 1977:23-26. 



\section{6}

\section{HATARAT NEDARIM: The Dissolution of Vows}

\section{[1] Hatarat Nedarim and Lack of Proper Intent}

Biblical law makes no provision for the dissolution of vows and oaths. The Israelites honor their treaty with the Gibeonites, sanctioned by oath, even though the Gibeonites acted in bad faith, and the treaty was sworn to under false pretenses (Joshua 9:15-27). Jephthah is obligated to sacrifice the first living being he encounters upon his return from battle even when this proves to be his daughter (Judges 11:35). The Israelites carry out their sworn resolution not to intermarry with the Benjaminites even though they regret it (Judges 21:1-7). From these stories and others ${ }^{1}$ it is apparent (a) that misinformation, misunderstanding, and unforeseen events are not grounds for the dissolution of an oath or vow, and (b) that no one has the authority to absolve the votary of his vow or oath. ${ }^{2}$

\footnotetext{
${ }^{1}$ In I Samuel 14:45 Jonathan is condemned to death for violating his father Saul's adjuration, but is "rescued" by a counter-oath of the people, not to carry out the execution that day. Read with LXX הזיום ימות instead of MT היונת 'see McCarter $1980: 248$ ). It would seem, however, that the curse of Saul's adjuration was never lifted. Jonathan dies shortly thereafter (I Samuel 31:2).

${ }^{2}$ The Rabbis, who anachronistically retrojected their own institution of hatarat nedarim and their conception that oaths made without proper intent are not binding onto the biblical stories, explain that Joshua decided to keep his treaty with the Gibeonites in order to "sanctify God's name" (BT Gittin 46a). On the other hand, Judges 21 is interpreted as an example of hatarah; the Benjaminites were permitted to take the virgins of Jabesh-Gilead as wives only after the oath was rescinded (PT Taanit 4:11, 69c). According to Genesis Rabbah 60:3, Jephthah was too proud to apply to the high priest Phineas for absolution from his vow.
} 
The Rabbis, however, considered vows which by convention were mere bargaining tactics ${ }^{3}$ or figures of speech, ${ }^{4}$ vows based upon misapprehension, ${ }^{5}$ and vows which could not be fulfilled by reason of a constraint beyond the votary's control ${ }^{6}$ not binding. Moreover, they felt themselves empowered to absolve the votary of his vow and the swearer of his oath, in these and other circumstances. ${ }^{7}$ An early mishnah, which dates according to some scholars to Herodian times, ${ }^{8}$ and according to others to the rabbinic assembly at Yavneh shortly after the destruction of the Temple, ${ }^{9}$ acknowledges the fact that these rabbinic laws regarding the dissolution of vows have no basis in Scripture: "The dissolution of vows flies in the air and has nothing to stand on" (Mishnah Hagigah 1:8). The precise meaning of the phrase היתר נדרים, literally, "the dissolution of vows," is unclear. It may refer to the rabbinic view that vows based upon misinformation or convention of various types are not binding, ${ }^{10}$ or it may refer to the rabbinic notion that a person can seek the dissolution of any vow from a rabbi. ${ }^{11}$

How and why did these rabbinic notions arise? $\mathrm{H}$. Albeck cites the gloss on Mishnah Hagigah 1:8 found in Tosefta Hagigah 1:9: "The dissolution of vows flies in the air and has nothing to stand on, but the sage can dissolve a vow by means of his wisdom," in order to show that the role of the sage in dissolving vows is similar to the role of the tax lawyer: he finds loopholes which render the original vow not binding. ${ }^{12}$ In general, these loopholes have to do with intention: the vow as executed would involve more than the votary had intended. ${ }^{13}$ The Rabbis in general, and the school of Hillel in particular, considered intention a

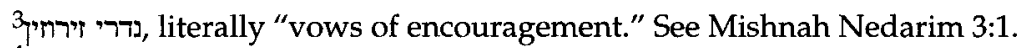

נדרי הבאי, "vows of gross exaggeration" made in casual conversation. See Mishnah Nedarim 3:2; Benovitz 1993:554-592.

5. מדרי שגנות. See Mishnah Nedarim 3:2; Benovitz 1993:401-407, 538-541.

6. See Mishnah Nedarim 3:3. This category also includes vows made under duress; see Mishnah Nedarim 3:4; Benovitz 1993:401-407.

${ }^{7}$ See Mishnah Nedarim Chapter 9, and sources cited below, notes 21, 43, and 44 .

${ }^{8}$ Epstein 1957:46-47.

${ }^{9}$ Efrati 1973:50-55.

${ }^{10}$ See Albeck 1959:140, and compare PT Hagigah 1:8, 76c and BT Hagigah 10a, which cite the opinion of Rabbi Joshua, according to which is derived from God's contention in Psalm 95:11 that he swore "in anger" not to lead the Israelites into Canaan, and therefore, in verse 7 , he reneges on his rash oath. Rabbi Joshua clearly understands היתר נדרים as the rabbinic notion that vows made without proper intent are not binding.

${ }^{11}$ This is the conventional interpretation. See Mishnah commentators ad loc., Tosefta Hagigah 1:9, and Lieberman 1962, volume 5:1285.

${ }^{12}$ Albeck 1959:140. Cf. also Epstein 1957:377, and S. Abramson as cited in Baer 1966:121.

${ }^{13}$ See Albeck 1959:140-141. 
mitigating factor with regard to many biblical laws: ${ }^{14}$ the validity of a sacrifice is affected by the intent of the officiating priest, a notion foreign to the Torah itself; ${ }^{15}$ whether or not an object is susceptible to impurity can be dependent upon the intended use of the object; ${ }^{16}$ prayer $^{17}$ and other ritual acts ${ }^{18}$ are valid only if one intends to fulfill his obligation. It would thus seem, at first glance, that Albeck is correct in viewing the rabbinic notion of the dissolution of vows in the same light. A votary who does not foresee the implications of his vow even though they could have been foreseen, ${ }^{19}$ or one who vows based upon misunderstanding, or one who vows merely as a matter of convention, does not have the proper intent, and therefore his vow is not binding.

However, a number of questions come to mind when we attempt to view the dissolution of vows in the context of the general rabbinic emphasis on intention. First of all, why does the mishnah in Hagigah consider the rabbinic notion unfounded, if indeed it merely involves the application of the rabbinic principle of intent to the laws of vows? How is this any different from any other of the numerous applications of the rabbinic principle of intent cited above? Second of all, not all of the rabbinic grounds for dissolution can be easily subsumed under the category of "lack of intent" or "lack of proper intent." 20 In fact, according to one view, mere regret is sufficient grounds for the cancellation of the vow. ${ }^{21}$ The Rabbis also deemed false vows used as bargaining tactics not

\footnotetext{
14See Eilberg-Schwartz 1986; Urbach 1986:179-193; Gilat 1992:72-83.

${ }^{15}$ See Mishnah Zevahim 1:2, 3:2; Tosefta Menahot 5:6.

${ }^{16}$ See Mishnah Kelim 25:9; Mishnah Makhshirin 6:1; BT Qiddushin 59b.

${ }^{17}$ See Mishnah Berakhot 2:1, 5:1; BT Berakhot 12a.

${ }^{18}$ See Mishnah Rosh Hashanah 3:7; Tosefta Rosh Hashanah 4:7.

${ }^{19} \mathrm{Cf}$. Epstein's claim (Epstein 1957:377) that the rabbinic decision to permit vows detrimental to one's parents is influenced by Jesus' polemic against the Pharisees in Matthew 15 and Mark 7 (see above, Chapter 1, section 3).

${ }^{20}$ The major categories of grounds for absolution cited in Mishnah Nedarim Chapter 9 are nolad ("unforeseen events") and kavod ("respect" for one's parents, children, or self). Neither of these indicate lack of proper intent at the time of the vow. Nolad implies that under the circumstances at the time of the vow, the votary's intent was perfectly sound; subsequent events made him change his mind. Kavod is also difficult to subsume under the rubric of lack of proper intent: if the votary had no idea how his relatives would react or how he would feel about the vow, then it is tantamount to nolad as far as intent is concerned; if he did have some idea of their possible reaction, then he probably would not have vowed unless he asked them first.

${ }^{21}$ Rabbi Judah ben Bathyra in Tosefta Nedarim 5:1 ("They say to him, 'If you had had the heart you have now at the time, would you have vowed?'" ), paraphrased in BT Nedarim 21a as פותחין בחרטה, "regret may be used as a loophole." Cf. Rabbi Judah ben Bathyra's claim in Mishnah Nedarim 9:9 that "self-respect" may be used as a loophole; this would seem to be more or less the same thing as "regret."
} 
binding, even though to be effective they would have to be believed by the other party. Thirdly, why did the Rabbis insist that a person who made a vow lacking the proper intent approach a sage and request its dissolution? A prayer or a sacrifice performed without the proper intent is invalid in and of its own accord, without the official release of a sage!

\section{[2] Hatarat Nedarim as a Power Vested in the Rabbis}

This last point deserves further amplification. We have already noted that it is unclear whether the term היתר נדרים, "dissolution of vows," in Mishnah Hagigah 1:8 refers to the various loopholes which the Rabbis considered grounds for the dissolution of vows, or the formal dissolution by a sage. Indeed, it is unclear whether these two phenomena are the same or different: Chapter Three of Mishnah Nedarim refers to "four types of vows deemed not binding by the Sages" (vows used in bargaining, vows of gross exaggeration, vows made on the basis of misinformation, and vows that cannot be fulfilled by reason of constraint), while Mishnah Nedarim Chapter Nine refers to various grounds on the basis of which a vow can be "opened" by a sage. Some of the amoraim believe that the two chapters are referring to the same phenomenon: the Rabbis deemed four types of vows not binding, but they nonetheless suggested that a votary who believes his vow to fall under one of these categories check with a rabbi, who will weigh the situation and then rule as to whether or not the vow was valid. ${ }^{22}$ Other amoraim believed that there is no relationship between the two chapters: Chapter Three lists types of vows that are not binding at all, for which no release need be sought, while Chapter Nine lists vows that are binding, and are thus subject to release only at the discretion of a rabbi. ${ }^{23}$

It would seem that two different conceptions of the dissolution of vows coexisted in tannaitic and amoraic times. Mishnah Hagigah 1:8, which deems the institution of dissolution baseless, views the dissolution

\footnotetext{
${ }^{22}$ The amora Isi/Asi in PT Nedarim 3:1, 37d; BT Nedarim 21b. This may also be the position of Rav and Samuel according to PT; see commentators ad loc.

${ }^{23}$ Rabbi Eleazar in the name of Rabbi Hiyya the Great in PT Nedarim 3:1, 37d; Rav and Samuel according to BT Nedarim 21b (and possibly also according to PT; see commentators ad loc.). Albeck (1959:141, note 17) objects to this view on the basis of Tosefta Gittin 4:3, which states that vows based upon misinformation can be dissolved without the investigation of a sage, from which Albeck infers that they do require the formal dissolution of a sage, albeit without an inquiry on the part of the sage. But it seems more likely that the term חירת חספ, "the investigation of a sage," in Tosefta Gittin 4:3 is a synonym for שהלת חכם, "application to a sage [for dissolution],". and thus Tosefta Gittin actually proves that vows based upon misinformation are automatically invalid, even without recourse to a sage.
} 
of vows as a power vested in the Rabbis, a power that has no basis in Scripture. Tosefta Hagigah 1:9, by contrast, views dissolution as analogous to any other rabbinic ruling: the sage finds grounds which render the vow not binding $a b$ initio. It would seem that the amoraim who believe that the sage dissolving the vow must rule in accordance with the rulings in Chapter Three of Mishnah Nedarim agree with the latter conception: a sage has no special power to dissolve vows; rather, he acts by means of his wisdom, finding loopholes in the intent of the votary which deem the vow not-binding in and of itself. But those amoraim who believe that a sage can absolve a votary even of vows not included in the four categories of Mishnah Nedarim Chapter Three believe, in accordance with Mishnah Hagigah 1:8, that the dissolution of vows is a power inexplicably granted to the Rabbis to be used at their discretion. Once a sage has determined the sincerity of the votary and his genuine regret, no "grounds" are needed to validate the dissolution. The grounds are needed not in order to permit the sage to dissolve the vow, but in order to convince him that he should dissolve the vow. If no grounds are extant, the votary may begin to take the institution of vows lightly. Therefore, as an educational tool, a sage should refuse to absolve the votary of his vow unless he feels it is warranted by the circumstances. ${ }^{24}$

\section{[3] The Evidence of Philo}

Which of these two conceptions is original: the view according to which the sage finds grounds for annulling the vow or the view according to which the sage has the power to annul the vow? Which accounts for the origin of this strange institution, which seems to undermine the very sanctity of the vow?

As stated above, Albeck posits that the rationalistic, "grounds" approach is the more original. According to Albeck, even the more dubious grounds cited in rabbinic literature, such as mere regret, invalidate the vow $a b$ initio, since the votary is in effect claiming to have vowed rashly and without the proper forethought. ${ }^{25}$ Albeck cites

${ }^{24}$ Cf. Tosefta Nedarim 1:6, PT Nazir 5:4, 54a, BT Nedarim 20a, and BT Nazir 32a, according to which a sage should refuse to discuss absolution with someone who has already violated his vow, until he keeps the vow for as many days as he had violated it. See Benovitz 1993:501-506.

${ }^{25}$ Albeck's view is very problematic. The term חרסה, "regret," implies regret after the fact, not haste at the time the vow was taken. Moreover, the notion of nolad (Mishnah Nedarim 9:2, see above, note 20) clearly indicates that even if the vow was deliberate, but circumstances changed subsequently, the sage may dissolve the vow. Albeck does not discuss this issue. It would seem more correct to say that if, indeed, the sages originally acted as mere agents and assistants in finding 
evidence in Second Temple sources to support his view: Josephus writes that some of the elders in biblical times believed the oath against intermarriage with the Benjaminites should not be honored because it was uttered rashly, ${ }^{26}$ an anachronism that seems to reflect the fact that the Rabbis of his own day, or at least some of them, deemed certain types of vows and haramim not binding. ${ }^{27}$

Albeck also cites Philo, de Specialibus Legibus II,9, in support of the notion that vows made in anger or lustful yearning are not considered vows at all. ${ }^{28}$ In fact, however, Philo says nothing of the kind. The citation from Philo reads as follows:

[One who swears] should use all his strength and every means in his power to make good his oath, and allow nothing to hinder him from carrying out his decision, particularly when he has taken the oath in a reasonable and sober frame of mind, not distraught by savage tempers or frenzied yearnings or uncontrollable desires, so that he does not know what he says or does.

Philo is unclear about the precise status of oaths made by one distraught, who does not know what he says or does. He clearly believes that even such oaths should be kept, but not at any cost. In II,15 he suggests that if such oaths are taken for improper purposes they should not be kept, but God must be propitiated with sacrifice and prayer. The same is true of antisocial oaths (II,17). These passages indicate, however, that the oath or vow is binding, and therefore the swearer or votary ignores his oath or vow at his own peril, and must seek the mercy of God. ${ }^{29}$

In his Hypothetica, Philo reiterates the notion that vows made without proper intent are binding. He suggests a different basis for the dissolution of vows, one which has nothing at all to do with the fact that vows uttered rashly or without proper intent are not binding. He writes as follows:

Each individual is master of his possessions unless he has solemnly named the name God over them or declared that he has given them to God. And if he has merely made a chance verbal promise of them he must not touch or handle them, but hold himself debarred from

loopholes, the public began to perceive the role of the sage in a "magical" light, and gradually the sages began to live up to the public expectations and absolve people of vows on dubious grounds, as though invested with a special power, thus giving rise to the "magical" approach. The fact that not all tannaim deemed all grounds for dissolution valid would seem to indicate that there existed a core of "rational" grounds, which was later expanded by some.

26Josephus, Antiquities V,2,12.

${ }^{27}$ See Belkin 1940:165; Albeck 1959:140-141.

${ }^{28}$ Albeck 1959:141.

${ }^{29} \mathrm{Cf}$. the position of the Damascus Document regarding oaths in violation of Torah law, above, Chapter 1, note 36 . 
them all...even with his own, I repeat, a chance word of dedication spoken unawares deprives him of them all and if he repents or denies his promise his life is forfeit also. The same holds of any other persons over whom he has authority. If a man has devoted his wife's sustenance...he must refrain from giving her that sustenance; so with a father's gifts to his son or a ruler's to his subjects. The chief and most perfect way of releasing dedicated property is by the priest refusing it, for he is empowered by God to accept it. Next to this, that [way of releasing] given by those who at the time have the higher authority may lawfully declare that God is propitiated so that there is no necessity to accept the dedication. ${ }^{30}$

From this passage it is clear that even a chance word, uttered "unawares," constitutes a binding vow. However, one can apply to the priest for release from any vow, because God appointed the priests his agents to receive the gift, and therefore they have the right of refusal on God's behalf. According to Philo, this is the source of the dissolution of dedicatory vows. "Those who at the time have the higher authority" (a phrase that presumably includes those referred to in the Mishnah as "sages") can substitute for the priest in their capacity as communal leaders.

Philo is making two claims here: that the priest is empowered to refuse a dedicated offering, and that the sages can substitute for the priest in this role. As far as I am aware, neither of Philo's assertions are corroborated by biblical or other Second Temple sources. Nowhere does the Torah speak of a priest's power to refuse a sacrifice; on the contrary, his role is clearly defined in Leviticus 27 : he assesses the property dedicated and is responsible for putting it up for sale or redemption. The very fact that dedicatory offerings are not necessarily put to use in the Temple, but are for the most part put up for sale or redemption, would seem to indicate that there is no possibility of or need for the rejection of unwanted items. ${ }^{31}$

30Philo, Hypothetica 7.3-5.

${ }^{31}$ According to Tosefta Arakhin 4:9, the donor can be forced to bid upon his own donated field for redemption immediately following the dedication. Mishnah Arakhin 8:1 cites a case in which a donor dedicated a worthless field, and then was asked to bid upon it immediately. He bid the minimal sum of one isar, and the priests accepted the bid. This indicates that the common practice in cases where the field was of no value to the Temple treasury was to force the donor himself to redeem the field, and not to release him from his vow. However, the basis for the rabbinic view that the donor can be forced to bid upon his field is unclear; moreover, it is unclear how this was enforced. Philo's description therefore probably reflects the actual practice in Temple times. Note also that according to Mishnah Arakhin 8:1 the donor is told to bid first (אומרין), rather than compelled to do so (כופין אותו) as in the Tosefta. See BT Arakhin 27a. 
Moreover, the notion that a sage can substitute for the priest in his capacity as God's agent for the rejection of offerings is also questionable: how can a sage possibly know whether or not the item in question is needed in the Temple or not? What authority does he have to declare God propitiated?

Nonetheless, these very questions make it likely that Philo's view on the dissolution of dedicatory vows actually reflects the Second Temple practice witnessed by Philo. Philo would have had no reason or occasion to make up these facts, which do not serve his main thesis in the Hypothetica: that the Jews are extremely scrupulous in the execution of vows.

Moreover, while neither of Philo's claims are directly corroborated by biblical, Second Temple, or rabbinic halakhic literature, both Philo's assertion that offerings can be rejected by the priests and his assertion that the sages assumed this duty are alluded to in rabbinic literature. PT Shabbat 1:1, $2 b$ cites Exodus $36: 6$ as the Torah source for the notion that carrying objects from one domain to another is a type of work, and is thus forbidden on the Sabbath. Exodus 36:6 reads as follows: "Moses commanded that they proclaim throughout the camp, saying, 'Let neither man nor woman do any more work for the offering of the sanctuary.' So the people refrained from bringing." PT comments:

The people refrained from taking the offerings out of their houses and giving them to the treasurers (גברים)....Just as the people refrained from bringing the offerings out of their houses and giving them to the treasurers, the treasurers refrained from accepting the offerings from their hands and bringing them into the Temple chamber (לשכה).

The word גiג is the rabbinic term for the treasurer in charge of Temple property; the word לשכה refers to the Temple chamber in which the offerings were stored. ${ }^{32}$ The anachronistic use of these terms with reference to the (as yet unbuilt[!]) Tabernacle makes it clear that PT viewed the donations in Exodus as analogous to offerings to the Temple treasury in Second Temple times. It is thus apparent that according to PT, the treasurer of the sacred property can refuse donations even after they had been dedicated, despite the rabbinic assertion (in agreement with Philo) that mere speech is enough to dedicate property to the Temple, and that immediately upon dedication the ownership of the

\footnotetext{
${ }^{32}$ The title, גובר for the Temple treasurer is of Persian origin, and is used in Ezra 1:8 and Ezra 7:21 of Persian treasury officials. For the precise role of the גבר their place in the Temple hierarchy, see Mishnah Sheqalim 5:2; Tosefta Horayot 2:10; Tosefta Menahot 13:21. For the term לשכה in the sense of Temple treasury, see Mishnah Sheqalim Chapters 3 and 4.
} 
property is transferred to the Temple, and the property becomes sacred (אמירתו לגבוה כמסירחו להריום). ${ }^{33}$ Presumably, the sanctity of the property is dependent upon the discretion of the treasurer: if the treasurer rejects the offering, the sanctity is nullified retroactively. ${ }^{34}$ This law is not mentioned in rabbinic legal literature except in this context, with reference to the construction of the Tabernacle, presumably because under normal circumstances the treasurer would have no reason to reject the offering, since it could be sold or redeemed by the offerer, with the proceeds accruing to the Temple treasury. However, when the donations for the construction of the Tabernacle exceeded the needs of the craftsmen, the offerings were rejected, and thus offerings could theoretically be rejected by Temple officials.

There is also evidence in rabbinic literature for Philo's second assertion, that rabbis replaced the priests in their duties as Temple treasurers. Mishnah Sanhedrin 1:1-3 lists various judicial functions carried out by a court of three:

Monetary cases are adjudicated in a court of three; robbery and torts are adjudicated in a court of three; damages...rape and seduction....cases for which the penalty is flagellation...the decision regarding the intercalation of [an extra day in] the month...the decision regarding the intercalation [of an extra month in] the year is made by a court of three...the delegation of sages for the laying of the hands upon a communal sin-offering...is composed of three...the release of a levir from his levirate duties and the annulment [of the marriage of a minor] is conducted by a court of three; the redemption of the fruit of the fourth year and of the second tithe whose value is unclear is conducted before a court of three; offerings to the Temple - before a court of three; evaluations...of moveable property [pledged to the Temple] are conducted by a court of three. Rabbi Judah says: one of them must be a priest. Real

\footnotetext{
${ }^{33}$ Mishnah Qiddushin 1:6; see above, Chapter 1, note 7.

${ }^{34}$ See Siftei Kohen to Shulhan Aruch Hoshen Mishpat 255:6, who insists that although property becomes heqdesh through mere speech, even before it is transferred to the Temple, this sanctity is contingent on the fact that the dedicatory vow is not subsequently dissolved, since speech can annul mere speech (אתי דיבור ומבטל דיבור). See also the opinion of Rashba cited there, who seems to allude to the possibility that annulment of a vow is tantamount to a lay person's rejection of a gift, and just as a lay person can reject a gift even after he has taken it into his hands, so too the sage can "reject" a donated object even after it has been made heqdesh through a votive formula.

According to Mishnah Nedarim 3:5, the donor cannot redeem property from the Temple until the transfer of ownership to the Temple has actually taken place. But this in no way contradicts our contention here. Redemption is actually repurchasing the property from the Temple; this obviously cannot be done unless and until the Temple actually owns the property. On the other hand, rejection of a donation can and should logically be done in advance.
} 
property - by nine and a priest; and the evaluation of persons is the same [nine and a priest].

These last items are puzzling: in what sense is the supervision and evaluation of various types of Temple offerings a judicial function, entrusted to a rabbinical court? ${ }^{35}$ Leviticus 27 repeatedly assigns this role to "the priest," but the Rabbis derived through one of their hermeneutical principles that the function of Temple treasurer is carried out by ten men, of whom only one need be a priest. ${ }^{36}$ This is clearly a later justification of the rabbinic appropriation of the role of Temple treasurer. While there is no direct evidence that laymen or sages actually appropriated the priestly role of treasurer on a regular basis during Temple times, Philo does indicate that at least occasionally "those who at the time have the higher authority" could and did release people from their dedicatory vows. Perhaps the reality that lies behind both Philo's assertion and the "court" mentioned in Mishnah Sanhedrin is that of Temple functionaries who handled dedicatory vows made outside of Jerusalem. Where priests were unavailable, prominent lay people may have been assigned the role of Temple treasury agents. Presumably these lay agents were assigned all the relevant tasks by the Temple officials: they assessed the donation and supervised its transfer to Jerusalem; and if the Temple priests could at least theoretically "reject" the offering on behalf of the Temple, then so could their lay representatives.

We have already established in Chapter One that prohibitive vows are an outgrowth of dedicatory vows: the votary dedicates to the Temple the very property from which he or the person named in the vow will derive benefit, thereby engendering trespass against Temple property the moment the property is used. ${ }^{37}$ The vow paradoxically takes effect immediately upon its violation. This being the case, prohibitive vows should also be subject, at least in theory, to the discretion of the priest: if the priest or Temple treasurer declares, before the vow is violated, that the Temple has no need of the property in question, then presumably the vow is canceled in advance, and when the property is used, it does not automatically become Temple property. Thus a priest or sage acting on

\footnotetext{
${ }^{35}$ See also Mishnah Megillah 4:3, which lists the requirement that ten people officiate at the dedication of real property to the Temple among occasions that require a minyan, a quorum of ten for ritual purposes.

${ }^{36}$ Leviticus 27 mentions the word כהן, priest, ten times in discussing the role of Temple treasurer. The Rabbis asserted that this unnecessary repetition comes to teach that ten people are needed to fulfill the duties of Temple treasurer, but only the first need be a priest, because of the principle that repeated information actually comes to exclude the very thing that it purports to include אין ריבוי אחר ריבוי אלא למעם

${ }^{37}$ See Chapter 1 above.
} 
behalf of the Temple treasury can declare both dedicatory and prohibitive vows null and void, simply by rejecting the property that has been dedicated to the Temple.

It would seem that it is this form of היתר נדרים that is referred to in Mishnah Hagigah 1:8: "The dissolution of vows flies in the air and has nothing to stand on." Leviticus 27 does not allow for the rejection of donations by the priest; the allusion in Exodus 36:6 is irrelevant, since it does not refer to Temple property, but to property used in the construction of the Temple. Thus the power granted to priest or lay authority or sage to "declare God propitiated" and thus annul the dedicatory or prohibitive vow has no basis in Scripture.

\section{[4] Hatarat Nedarim Prior to the Destruction of the Temple}

Any vow, dedicatory or prohibitive, could thus theoretically be annulled at the discretion of a priest or sage acting as God's agent. At the same time, some believed that vows and oaths uttered without proper intent are not binding. Both of these conceptions originated during the Second Temple period, and they originally had nothing to do with one another. Vows lacking proper intent simply do not take effect; proper intent is a requisite for vows and oaths, as it is for other halakhic acts. Vows made with proper intent may be "loosened" at the discretion of priest or sage, acting as the agent of the Temple in rejecting the "offering" on God's behalf.

\footnotetext{
${ }^{38}$ The cultic background of the rabbinic institution of the dissolution of vows may be alluded to in Mishnah Nedarim 8:7, a mishnah which should probably be grouped with the mishnayot in Chapter 9, and which therefore constitutes the opening mishnah in the section of Tractate Nedarim that deals with rabbinic dissolution:
}

If one says to his friend, "qonam is the benefit that I shall derive from you, unless you come and take for your sons one kor of wheat and two barrels of wine," he can be released from the vow without appeal to a sage, for the friend can say to him, "Did you not vow out of respect for me? This is the way to show respect [not by giving my sons gifts, but by coming to dine with me]." And similarly, if one says to his friend, "qonam is the benefit that you shall derive from me, unless you come and give my son one kor of wheat and two barrels of wine"...he, too, can be released without appeal to a sage, since he can say, "I consider it as though I received them."

These vows can be dissolved without recourse to a sage, because instead of the priest or sage declaring God propitiated without the dedication of the object, the votary or his friend can declare himself propitiated without the gift. 
Early tannaitic literature distinguishes between these two types of "dissolved" vows. Mishnah Nedarim 3:1-4 deals with four types of vows made without proper intent that are deemed not binding by the Rabbis: vows used in bargaining, vows of gross exaggeration, vows based upon misunderstanding, and vows which are made under constraint or which cannot be fulfilled by reason of constraint.

This passage of Mishnah dates to Temple times, as is apparent from the fact that the schools of Shammai and Hillel, which flourished during the period immediately preceding the destruction of the Temple, are twice mentioned $(3: 2,3: 4)$. Moreover, the only other attributed statement in the passage, Rabbi Eliezer ben Jacob's statement in 3:1, may also date from Temple times, since one of the two tannaim named Eliezer ben Jacob flourished during the end of the Second Temple period. ${ }^{39}$ The earliest stratum in the passage may predate Eliezer ben Jacob and the schools of Shammai and Hillel, since there are indications that the attributed material has been interpolated into an earlier layer of material. ${ }^{40}$

Mishnah Nedarim 3:1-4 makes no mention of the role of the priest or sage in dissolving these types of vows; on the contrary, the heading of the chapter, "Four types of vows were deemed not binding by the Rabbis," would seem to indicate that the Rabbis declared the four types of vows non-binding in a blanket declaration, and no rabbinic sanction is needed to loosen a vow made under these circumstances. This should be compared to Philo's assertion that vows made in the heat of passion with bad consequences should not necessarily be kept, ${ }^{41}$ and Josephus' claim that some members of the council during biblical times wished to declare the herem against the Benjaminites not binding, since it was declared rashly. ${ }^{42}$

Early rabbinic evidence also indicates that the possibility of applying to the authorities for release from a vow was a phenomenon associated with the Temple. According to an amoraic tradition, the school of Shammai did not allow for the dissolution of dedicatory vows, while the

\footnotetext{
${ }^{39}$ See Encyclopedia Judaica, s.v. Eliezer ben Jacob.

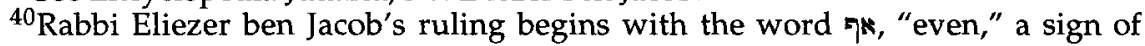
interpolation into an earlier stratum. See Epstein 1948:114; Lieberman 1967, volume 7:414. Similarly, if we read instead of in Mishnah Nedarim 3:2 (see Epstein 1948:1109), the dispute between the schools of Shammai and Hillel becomes an interpolation into an earlier stratum. In Mishnah Nedarim 3:4 the disputes between the schools of Shammai and Hillel clearly involve the interpretation of an earlier law.

${ }^{41}$ Philo, de Specialibus Legibus, II, 17. See Belkin 1940: 156-161, and above, note 28.

${ }^{42}$ See above, note 26 .
} 
school of Hillel did. ${ }^{43}$ But in fact it is clear from Mishnah Nazir 5:3 that the school of Shammai did allow for the dissolution of naziriteship and the accompanying offerings, and presumably the same is true of other dedicatory vows. ${ }^{44}$

To sum up, evidence from the Second Temple period indicates that we must distinguish between two independent phenomena, neither of which is necessarily more original than the other: the notion that vows without proper intent are in and of themselves not binding, and the fact that priests and sages were empowered to "reject" votive offerings on behalf of God and the Temple, at the request of the votary. The former phenomenon is attested by Josephus, who refers to "elders" who believed the oath regarding the Benjaminites should not be considered binding, the early stratum of Mishnah Nedarim Chapter Three, and perhaps also Mishnah Nazir 5:1-2. It is apparently a uniquely rabbinic notion, not shared by sectarians, and it should be associated with the general rabbinic emphasis on proper intent. The latter phenomenon, on the other hand, is attested by Philo and Mishnah Nazir 5:3.45

\footnotetext{
${ }^{43}$ See PT Nazir 5:1, 54a; BT Nedarim 78a, Nazir 9a, Bava Batra 120b, BT Arakhin $23 \mathrm{a}$ (where the amoraic tradition is read into a baraita!).

${ }^{44}$ See Lieberman 1967, volume 7:539. Lieberman, following PT Nazir 5:1, 54a, assumes, like Albeck, that the question of the dissolution of naziriteship or dedicatory vows is contingent upon the question of the status of naziriteship or dedicatory vows made without proper intent, since he assumes that the sage dissolved the vow by finding loopholes which render the vow invalid ab initio. Hence he sees a contradiction between Mishnah Nazir 5:1, in which the school of Shammai claims that unintended dedicatory vows are binding, and Mishnah Nazir 5:3, in which they allow for the dissolution of naziriteship and the accompanying offerings by a sage. In fact there is no contradiction: the school of Shammai recognizes the power of a priest or sage to reject a dedicatory vow or naziriteship on God's behalf, but they deny that loopholes can render a dedicatory vow invalid ab initio.

${ }^{45}$ One story in rabbinic literature, if taken at face value, would seem to indicate that even the absolution of dedicatory vows and naziriteships during Temple times was contingent upon finding appropriate grounds, and that the role of the sage was to find a loophole rendering the vow invalid $a b$ initio. PT Berakhot 7:2, 11 b (// PT Nazir 5:5, 55b // Genesis Rabbah 91) cites a Hebrew baraita with Aramaic elaboration. The baraita reads as follows:
}

Three hundred nazirites came up to Jerusalem [to bring their sacrifices, which they could not afford] in the days of Simeon ben Shetah. He found loopholes for one-hundred-and-fifty; for the other one-hundred-and-fifty he did not.

According to the Aramaic amoraic elaboration that follows, King Yannai (Alexander Janneus) agreed to pay for half of the nazirites on condition that Simeon pay for the remaining half, but Simeon annulled the vows of his half instead, whereupon Yannai became very angry. 


\section{[5] Hatarat Nedarim in Talmudic Law}

After the destruction of the Temple, the notion of applying to a priest or sage for release from a cultic vow was no longer relevant. However, the tradition of applying to a sage for release from a prohibitive vow continued. As we saw in Chapter One, the cultic significance of prohibitive vows was forgotten after the destruction of the Temple, and this significance was unclear to the general public even before the destruction of the Temple. ${ }^{46}$ The public thus continued to apply to the rabbis for dissolution from vows as though this were a special rabbinic power. At the same time, the rabbinic criteria for the automatic dissolution of vows, discussed in Nedarim Chapter Three, remained in effect, and presumably rabbis were also consulted as to whether a given vow met these criteria or not. ${ }^{47}$

Two similar phenomena thus existed side by side during the tannaitic period: the rabbinic notion that certain vows are not binding because of lack of proper intent, and the rabbinic role as priest-substitute, empowered to declare God propitiated and thus annul the vow. Although according to the early Mishnah Hagigah 1:8 there is no scriptural basis for this power, it was nonetheless apparently universally acknowledged and widely used both during Temple times and after the destruction of the Temple.

However, following the destruction of the Temple, when the cultic basis of prohibitive vows was forgotten, the tannaim were troubled by the unfounded rabbinic authority to annul any and all vows. Some tannaim therefore simply fused the two rabbinic roles. According to these tannaim, the sage has no "power" to annul vows; application for the annulment of a vow is merely the posing of a halakhic question to the rabbi: is my vow binding or not? Thus the Tosefta comments on Mishnah

Historians differ as to the historical import of this story: some deny its historicity entirely (see references in Efron 1987:150, notes 37-38); others claim that the story is based in part upon fragmentary historical traditions referring to either Alexander Jannaeus himself (Efron 1987:147-153) or Agrippa I (Goodblatt 1987:16-23, and references cited there, page 30, notes 60-61). However, even these scholars do not credit the detail that Simeon found loopholes for half of the nazirites, and this is apparently an anachronism. In fact, the story would seem to bear out our thesis according to which the Sages appropriated the right to reject Temple donations and grant release from vows from the priests some time before Philo; the dispute between Simeon and Yannai can be seen to reflect historical tension between sages and priests over the authority to grant automatic release from a dedicatory vow. Cf. Belkin 1940:167.

${ }^{46}$ See above, Chapter 1 , section 7 .

${ }^{47}$ The term for application to a sage for the dissolution of a vow, מאלת חכם , is the same term that is used for any other halakhic query concerning the ritual status of food, or other matters. See, e.g., BT Avodah Zarah 7a; Sanhedrin 65b. 
Hagigah 1:8: "The dissolution of vows flies in the air and has nothing to stand on - but the sage can dissolve a vow by means of his wisdom." According to these tannaim, the criteria for the annulment of a vow are no different than the four types of vows declared not binding by the Rabbis: the sage merely acts as a consultant. ${ }^{48}$

Other tannaim, however, continued to distinguish between the role of the sage as consultant in clarifying whether or not a vow is halakhically binding, and the power of the sage to annul vows at his discretion. Rabbi Eliezer, Rabbi Joshua, Rabbi Jonathan, and Rabbi Yose ben Judah all disagree with the contention of the early Mishnah Hagigah 1:8 that the rabbinic power to annul vows has no scriptural basis: each derives this power from Scripture. ${ }^{49}$ Two tannaim in particular, Rabbi Eliezer and Rabbi Judah ben Bathyra, both of whom often cite early halakhot, insist upon the right of the sage to annul vows even when the votary was fully aware of the facts and implications at the time of the vow. Rabbi Eliezer allows the sage to take into account developments subsequent to the time of the vow (פותחין בנולד), and annul a vow because of changed circumstances; ${ }^{50}$ he also allows the annulment of a vow if the votary's parents object. ${ }^{51}$ Rabbi Zadok, an adherent of the other school who insists upon proper grounds and lack of intent in order to validate an annulment, rightly declares, "If so (i.e., if Rabbi Eliezer's lenient position is correct), there is no such thing as a vow!"52 Rabbi Yehudah ben Bathyra goes further than Rabbi Eliezer, and allows the annulment of a vow if the votary himself objects, ${ }^{53}$ in other words, if the votary changed his mind.$^{54}$ He thus insists upon the rabbinic power to annul vows even without grounds, and even if the vow was made with the proper intent. It would seem that Rabbi Eliezer fundamentally agrees with Rabbi Judah ben Bathyra's blanket leniency; he merely insists that the sage use his power with some discretion, and insist upon a serious reason for the votary's change of heart. ${ }^{55}$

The amoraic dispute as to the relationship between Chapters Three and Nine in Mishnah Nedarim can likewise be traced back to these two

\footnotetext{
${ }^{48}$ See above, sections 1 and 2 of this chapter, and the references to the views of Albeck and Lieberman, cited in notes 25 and 45 above, respectively.

${ }^{49}$ See Sifre Bemidbar 73; Sifre Zuta to Numbers 30:2; and PT Hagigah 1:8, $76 \mathrm{c}$.

${ }^{50}$ Mishnah Nedarim 9:2.

${ }^{51}$ Mishnah Nedarim 9:1. See note 19 above.

${ }^{52}$ Mishnah Nedarim 9:1. This is the simple meaning of Rabbi Zadok's statement, as reflected in PT Nedarim 9:1, 41b. But see also the interpretations of the Babylonian amoraim in BT Nedarim 64a-b.

${ }^{53}$ Mishnah Nedarim 9:9.

${ }^{54}$ Tosefta Nedarim 5:1; BT Nedarim 21a. See note 21 above.

${ }^{55}$ Cf. Neusner 1973, volume 1:186.
} 
conceptions. Those amoraim who maintain that the four categories of vows listed in Mishnah Nedarim Chapter Three require the release of a sage, or that the only vows that a sage can dissolve are those listed in Chapter Three, view the two phenomena as identical: a sage grants release by finding grounds for release. ${ }^{56}$ Those who believe that the four categories of vows are automatically null and void, ${ }^{57}$ and that the sage's role is to grant release in other cases, where true grounds for annulment are lacking, view lack of proper intent and rabbinic release as two distinct issues, as they were originally, during Temple times.

Another amoraic dispute concerns the dissolution of oaths. In PT Nedarim 11:1, 42c, Rabbi Yohanan maintains that like vows and naziriteships, oaths can also be dissolved by a sage. Resh Laqish disagrees. BT assumes Rabbi Yohanan's position in a number of aggadot, ${ }^{58}$ and in BT Shevuot $27 \mathrm{~b}$ Rava and Amemar disagree as to the precise circumstances under which one can seek release from an oath. ${ }^{59}$ In BT Nedarim 28a Rav Ashi maintains (on the basis of Mishnah Nedarim 3:4) that the dispute ascribed by PT to Rabbi Yohanan and Resh Laqish is in fact a dispute between the houses of Hillel and Shammai. ${ }^{60}$

It is clear that Rabbi Yohanan's view, adopted by BT, that a sage can grant release from an oath as well as a vow, is rooted in the view that the sage merely finds loopholes in the original vow which render it not binding. If the sage's role is merely to find grounds which render the vow invalid $a b$ initio, there is no reason to distinguish between vows and oaths in this regard. On the other hand, Resh Laqish's view, according to which dissolution is unique to vows, is rooted in the Second Temple reality: the rabbinical power to release the votary is an outgrowth of the role of priest and sage as Temple functionary, and has nothing to do with the original intention of the votary. The Temple treasury has a role to play in the acceptance or rejection of vows, but oaths are a different matter entirely. No one is empowered to dissolve an oath, which is the invocation of a curse or punishment in the event that one's statement proves false.

\footnotetext{
56 See note 22 above.

${ }^{57}$ See note 23 above.

${ }^{58}$ BT Ketubot 77b; Sotah 36b; Sanhedrin 38a.

${ }^{59}$ See Benovitz 1993:501-523.

${ }^{60}$ But this is clearly a play of Rav Ashi's on the double entendre of the term 2 , and not the original meaning of Mishnah Nedarim 3:4. The dissolution of oaths is nowhere mentioned in tannaitic literature.
} 


\section{7}

\section{KOL NIDRE}

\section{[1] The Origin and Development of the Kol Nidre Formula}

The laws of vows, which formed an important part of talmudic legislation, were relegated to a position of lesser importance in posttalmudic halakhah. Rav Yehudai Gaon and Rav Natronai Gaon, who flourished in Babylonia during the seventh and eighth centuries respectively, attest that tractate Nedarim was not studied in the geonic academies; $;$ presumably vows were avoided entirely by the populace, rendering familiarity with the laws of vows and their dissolution unnecessary. Nonetheless, two curious customs associated with vows are practiced to this day on the high holy days:

(1) In some communities ${ }^{2}$ the individual seeks absolution from all his vows of the previous year from a "court" of three laymen on the morning before Rosh Hashanah or the morning before Yom Kippur. Following the morning service, the congregation divides into groups of four, each of whom take a turn petitioning the other three, who form a tribunal of laymen, using the following formula:

Hear ye gentlemen, expert judges: any vow, oath, issar, qonam or herem that I have vowed or sworn, when awake or while dreaming,

\footnotetext{
${ }^{1}$ See below, note 8 .

${ }^{2}$ The earliest attestation of this custom is Isaiah Horowitz's seventeenth-century description of the custom of Palestinian Ashkenazim (Shenei Luhot Haberit, Yoma, section 1). According to Horowitz, on the eve of Rosh Hashanah each member of the congregation petitioned the entire congregation for absolution with the formula cited here, following which the congregation as a whole granted absolution. The contemporary custom of dividing into groups of four probably arose in order to shorten the rite, for the sake of convenience. German Jews perform the rite on the eve of Yom Kippur. Sephardim do so forty days before Rosh Hashanah or forty days before Yom Kippur. See Kaf Hahayyim to Orah Hayyim 581, section 12 .
} 
or any oath that I have sworn using one of God's holy names that cannot be erased or the tetragrammaton, or any sort of naziriteship that I have undertaken, and any prohibition that I have imposed upon myself or others...I regret ever having uttered any of them, and I request and petition your excellencies for their dissolution, because I fear that I will, God forbid, stumble and fall with regard to the sin of [not keeping] vows, oaths, naziriteships, haramin, issarin, and qonamot. I do not regret having done good deeds; I simply regret having undertaken to do them using votive formulae...and although I know that by law a votary seeking absolution must specify the vow, be aware, gentlemen, that I cannot specify my vows, because they are many. I am not seeking absolution for vows that cannot be absolved; therefore I ask you to consider it as though I have specified the vows.

The tribunal responds:

They are all permitted to you; they are all forgiven you; they are all dissolved for you; there is no longer any vow or oath or naziriteship or herem or issar or qonam or excommunication or ban or curse; instead there is pardon and forgiveness and atonement. And just as the earthly tribunal dissolves them, so shall they be dissolved in the heavenly tribunal, and they shall have no effect at all.

(2) On Yom Kippur evening blanket absolution is granted from the pulpit for all the vows of the past and/or the coming year made by anyone in the congregation, with the formula known as Kol Nidre. The earliest extant version of Kol Nidre, which has survived in Hebrew, ${ }^{3}$ although its existence in Aramaic is also attested, ${ }^{4}$ reads as follows:

All vows, issarin, oaths, qonamot, and haramin that we have vowed
and prohibited and sworn and taken upon ourselves from last Yom
Kippur until the Yom Kippur that is about to commence - we
regret all of them, and we announce before our father in heaven
that if we vowed a vow, there is no vow; if we took upon ourselves
an issar, there is no issar; if we made a herem, there is no herem; if we
swore an oath, there is no oath; if we made a qonam, there is no
qonam. The vow is annulled ab initio, the oath is annulled ab intio,
and the qonam is annulled ab initio; there is neither vow nor issar nor
oath nor qonam, but rather pardon and forgiveness and atonement.

${ }^{3}$ This version is found in an addition to the Siddur of Amram Gaon, and in the mahzorim of Rome and Romania. See Goldschmidt 1970:26, note 1. This was the Palestinian version; see Herr 1980:75, note 70, and references cited there. Cf. also the ninth- and tenth-century Karaite polemics against the custom, which cite the Hebrew version (Mann 1972, volume 2:51), and Lewin 1942, volume 11:22.

${ }^{4}$ See Goldschmidt 1970:26, notes 2 and 3, and citation of the name of the prayer in the Geonic responsum cited below (see note 8). See also Rav Hai Gaon's emended Aramaic version, cited in Shibbolei Haleqet 317 (see Goldschmidt 1970:27, and note 5 there). 
In the Ashenazic rite today 5 the following version is used, in Aramaic:

All vows, issarin, haramin, qonamot, substitute formulae, qonas formulae, and oaths that we have vowed and sworn and declared herem and prohibited upon ourselves from this Yom Kippur to the coming Yom Kippur [sic] - we regret all of them. All of them shall be permitted, abandoned, set aside, null and void, invalid and nonexistent. The vows are not vows; the issarin are not issarin; and the oaths are not oaths.

These customs, and in particular the Kol Nidre formulae, have puzzled scholars for generations. ${ }^{6}$ As we have seen in the previous chapter, the halakhic rulings regarding the dissolution of vows are quite detailed; even according to the more lenient positions mentioned in the Talmud an individual must apply to a sage for the dissolution of a specific vow, whereupon the sage may or may not annul the vow. ${ }^{7}$ How and why did the custom evolve of granting blanket absolution from all vows and all types of votive formulae on the holiest night of the year, on which we are presumably expected to take our religious obligations most seriously?

Until recently, the earliest known reference to these customs was a passage from a responsum of Rav Natronai Gaon (eighth century) citing Rav Yehudai Gaon (seventh century), as follows:

And as to that which you asked: Can the congregation make contingent all vows which they vow from one year to the next? Answer: Tractate Nedarim has not been studied in the two academies for more than one hundred years. And Rav Yehudai Gaon, light of the world, said as follows: We do not study Nedarim, nor do we know how to rule strictly or leniently in this area, neither regarding vows nor regarding oaths, and it is not the custom in the academy or elsewhere to dissolve vows on Rosh Hashanah or Yom Kippur. Although we have heard that in other lands they say "Kol Nidre ve-Esare," we have neither seen it nor heard of it from our teachers. ${ }^{8}$

In the early part of the twentieth century, scholars debated the reference to "other lands" in which Kol Nidre was customary; the theory was that the provenance of the custom held a clue as to its meaning and origin. S. Poznanski and S. Krauss ${ }^{9}$ argued for a Palestinian provenance, viewing the custom as a public repudiation of the Karaites, who did not

${ }^{5}$ In most congregations. But see Goldschmidt 1970:27-28; Wieder 1978:189-209.

${ }^{6}$ See bibliography in Herr 1980:66, note 24 .

${ }^{7}$ See above, Chapter 6 .

${ }^{8}$ See Lewin 1942, volume 11:22-23. The responsum is found in a number of collections of Geonic responsa; for complete bibliography see Herr 1980:65-66, note 23.

${ }^{9}$ Poznanski 1918; Krauss 1928:85-97. 
accept the rabbinic institution of the dissolution of vows, which, as we have seen, has no scriptural basis. Against this view it is argued that since both the Karaites and Rav Yehudai describe the custom in terms that indicate that it has been long established, it is unlikely that it developed as a response to Karaism. ${ }^{10}$ Other scholars therefore retained the notion of Palestinian provenance, without accepting Poznanski and Krauss's theory as to the reason for the custom. ${ }^{11}$

J.S. Bloch argued that Kol Nidre arose in Visigothic Spain of the seventh century, among Jews forced to publicly renounce their religion under oath. ${ }^{12}$ This is apparently an attempt to retain the once widelyheld view that Kol Nidre originated among the Marranos in fifteenthcentury Spain; ${ }^{13}$ the original view was discredited with the discovery of the geonic responsum which antedated the Marranos by seven hundred years, ${ }^{14}$ and was thus modified, ad hoc, by Bloch. ${ }^{15}$ In fact, there is no evidence that the Jews of Visigothic Spain were sufficiently learned to come up with such a formula. Moreover, it is unlikely that a secret rite practiced in Spain under such conditions would have become common knowledge in Babylonia almost immediately.

I. Davidson, ${ }^{16}$ in a theory recently reiterated by M. D. Herr, ${ }^{17}$ argued for a Babylonian provenance, despite the geonic reference to "other lands." In the view of Davidson and Herr, Kol Nidre was originally an announcement made at the beginning of the year to the effect that all vows made in the coming year are to be considered null and void, as in the Ashkenazic rite. ${ }^{18}$ Since both a Hebrew version and an Aramaic version are extant, Davidson argued that this announcement was originally made by each individual: scholars made the announcement in Hebrew, while the ignorant used an Aramaic version. In his view, this dichotomy suggests Babylonian provenance. ${ }^{19}$ Finally, Davidson pointed out that it is the Babylonian Talmud (Nedarim 23b) which cites a baraita according to which one can announce on Rosh Hashanah that the vows of the coming year are void. ${ }^{20}$ During the geonic period, the formula gradually developed from an announcement concerning the coming year

\footnotetext{
${ }^{10}$ See Mann 1972, volume 2:53, note 100.

${ }^{11}$ Mann 1972, volume 2:51-52; Lewin 1942, volume 11:10; Goldschmidt 1970:24.

${ }^{12}$ Bloch 1922.

${ }^{13}$ See Herr 1980:67, note 25.

${ }^{14}$ See Herr 1980:67, note 26.

${ }^{15}$ See Herr 1980:67-68.

${ }^{16}$ Davidson 1923:180-194; in greater detail in Davidson 1929, volume 2:480.

${ }^{17}$ Herr 1980:67-76.

${ }^{18}$ See above, note 5 , and references there.

${ }^{19}$ Davidson 1929, volume 2:480.

${ }^{20}$ Davidson 1923:182; Davidson 1929, volume 2:480; Herr 1980:64.
} 
into a formula granting absolution for the vows of the past year, thus arousing geonic opposition. ${ }^{21}$

Davidson's theory not only ignores the clear evidence in the geonic responsum that the provenance was not Babylonian ("other lands"); ${ }^{22}$ it is also based entirely upon incorrect assumptions. The Aramaic of Kol Nidre as cited by the Geonim is certainly Babylonian, but the Palestinian custom was to use a Hebrew version, as cited by the Palestinian Karaites, ${ }^{23}$ and therefore it is unnecessary to posit that the Hebrew and Aramaic versions existed side by side from the very inception of the custom, as argued by Davidson. Moreover, all geonic versions clearly indicate that Kol Nidre was originally a formula for the dissolution of the past year's vows. None of the Geonim who oppose the custom suggests "reverting" to a more "original" custom of annulling future vows; ${ }^{24}$ it is Rashi's son-in-law, Meir ben Samuel of eleventh-century France, who first suggested this. ${ }^{25}$ Even in the version proposed by Meir ben Samuel and customary among Ashkenazim today, the verb forms ("that we have vowed...") are past tense, and the phrase "from this Yom Kippur until the next..." has been rather inelegantly superimposed upon a dissolution formula. ${ }^{26}$ The origin of the Asheknazic custom is clear: Meir ben Samuel emended the text because of geonic objections to mass release from past vows, and it is his son, Rabbenu Tam, who cites BT Nedarim $23 \mathrm{~b}$ as precedent for a ritual that his father originated. ${ }^{27}$ In fact, the phrase "on Rosh Hashanah" in the baraita in BT Nedarim does not refer to the high holy day season at all; it is used in contradistinction to בשעת הנדר, "at the time of the vow," and means simply, "well in advance." 28

\footnotetext{
${ }^{21}$ Davidson 1929, volume 2:480; Herr 1980:70.

${ }^{22}$ According to Herr 1980:75, the Geonic responsum refers to a period following the Geonic opposition, during which the custom was all but abolished in its native Babylonia. But this is far-fetched.

${ }^{23}$ See above, note 3 .

${ }^{24}$ The questioner who asks the question in the Geonic responsum refers to "making vows contingent," which may be a reference to the abrogation of future vows. However, the Gaon himself assumes that the question refers to the dissolution of past vows, as in the original Kol Nidre formula.

${ }^{25}$ See Goldschmidt 1970:27; Wieder 1978:189-209.

${ }^{26}$ Other later versions attempted to tidy up the Aramaic anomaly. See references cited in previous note.

${ }^{27}$ Rabbenu Tam, Sefer Hayashar, Hiddushim, section 100.

${ }^{28}$ For similar usage, see BT Pesahim $6 \mathrm{~b}$. The context in Nedarim 23a is so clear, that it is a wonder that any scholars view this text as the basis of the custom of reciting Kol Nidre during the high holy day season. Moreover, BT merely cites a version of a Palestinian tannatic text, in the name of Rabbi Eliezer ben Jacob, and thus there is no indication that original provenance of the ruling is Babylonian.
} 
Other scholars ${ }^{29}$ argue for the Babylonian provenance of Kol Nidre on the basis of the similarity of its language to Babylonian Jewish Aramaic magical texts, ${ }^{30}$ particularly magic bowls inscribed with formulae breaking spells, adjurations, and vows with which demons had been bound to carry out the will of men. ${ }^{31}$ According to these scholars, Kol Nidre originated in the same circles as these magical texts, and thus aroused the opposition of the Geonim, who opposed the practice of magic. $^{32}$

However, the reason the Geonim give for their opposition has nothing to do with magic. ${ }^{33}$ Moreover, it is clear that the magical texts are based upon Kol Nidre, and not the other way around. The writer of an amulet (or the one who casts an oral spell, but these, of course, have not survived) adjures a demon or demons and makes him swear and vow and conditionally forfeit his life under herem as a guarantee that he will harm so-and-so. So-and-so then inscribes a bowl with a formula releasing the demon from all vows, oaths, issarin, and haramin imposed by his enemy, and shatters the bowl. ${ }^{34}$ Needless to say, the amulets contain the very votive formulae and adjurations used among humans, and the bowls are inscribed with the formulae for the absolution of vows current among humans. The reason is not some inexplicable propensity

${ }^{29}$ See Gordon 1966:6-7, note 23, and others cited by Herr 1980:69, note 30 . This is also the view of Deshen 1980:145, and Herr himself, 1980:64, and note 22 there. ${ }^{30}$ See list of citations in Herr 1980:69-70, note 29.

${ }^{31}$ See Deshen 1980:145, and literature cited in note 12 there.

${ }^{32}$ Deshen goes a step further than the others, and argues that Kol Nidre itself, as recited in the synagogue, was originally a formula designed to chase away demons and break magic spells; he cites the following formula recited in the South Arabian Jewish community of Haban following Kol Nidre:

In the assembly above and in the assembly below, with the agreement of the Holy One, blessed be he, and Elijah and the court of Jerusalem and holy communities everywhere, we dissolve and abrogate and annul all adjurations with which any angel or devil or angel of destruction or [there follow the names of specific demons] is adjured. All of these shall be loosened, erased, forgiven, and dissolved.

Needless to say, this is a late development, and can hardly be said to reflect the original intent of the Kol Nidre prayer itself. See Merhaviah 1984:1076, note 86. ${ }^{33}$ See, at length, Merhaviah 1984:1084-1096.

${ }^{34}$ Merhaviah 1984:1074-1075 argues that the language of the magical text is in fact unrelated to the language of votive formulae and their abrogation. Each formulation arose independently in its own context, and any similarity is in his view coincidental. This view, too, is far-fetched and unnecessary. The spells and amulets are in fact adjurations, but of demons, not of people; the magic bowl inscriptions are in fact the regular dissolution formulae, but they are directed at demons, not at people. 
to use votive and magical terms interchangeably. ${ }^{35}$ Spells use votive formulae because a spell is actually an adjuration of evil spirits to do the will of the one reciting or writing the charm. The victim of the magic spell could thus make use of the regular formulae for the dissolution of vows, current among humans, in order to release the demons from their oaths.

There is thus no reason to posit a Babylonian origin for Kol Nidre. Recently discovered evidence has confirmed the Palestinian origin of the custom of dissolving vows publicly during the high holiday season. A Palestinian halakhic work from the Geniza contains the following ruling:

It is forbidden to dissolve vows on the night of Rosh Hashanah which falls on the Sabbath, but on Saturday night it is permitted, and it is forbidden both for the individual and for the community on the night of Rosh Hashanah which falls on the Sabbath. It is forbidden to dissolve the vow of an individual on Rosh Hashanah itself, whether it falls on a weekday or on the Sabbath. ${ }^{36}$

The reference to the dissolution of vows for the community indicates that in Palestine the dissolution of vows during the high holy day season had become a public event.

Mishnah Shabbat 24:5 permits the dissolution of a vow on the Sabbath only if the vow in question prevents proper observance of the Sabbath (לצורך השבת). The implication is that the dissolution of vows is normally forbidden on the Sabbath, either because it is a judicial procedure, ${ }^{37}$ or because it is tantamount to "repairing" the person bound by the vow. ${ }^{38}$ There is no explicit prohibition in the Talmud against dissolving vows on a festival, but Mishnah Betzah 5:2 would seem to indicate that there is no reason to distinguish between Sabbaths and festivals in this regard. ${ }^{39}$ Nonetheless, the public dissolution was performed on Rosh Hashanah in Palestine, and later, in Babylonia, even on the Sabbath. Rav Hai Gaon says that this is because "the community does not assemble except on the Sabbath, and if they do not do so on the

${ }^{35}$ Lieberman 1942:119 argues that magic terminology found its way into votive formulae because the biblical oath is in fact a curse. But it is much simpler to assume that votive terminology found its way into magic formulae because spells, amulets, and magic bowls are in fact adjurations.

36 See Rabinowitz 1972:287-288; Margaliot 1974:45.

${ }^{37}$ See BT Nedarim 77a; BT Shabbat 157a.

${ }^{38}$ Maimonides, Mishneh Torah, Shabbat 24:1,6. This would seem to be the simple meaning of Mishnah Shabbat $24: 5$ in context. See also BT Nedarim 77b, with reference to the manner in which the husband may annul his wife's vow on the Sabbath.

${ }^{39}$ According to this mishnah, all rabbinic prohibitions regarding the Sabbath are applicable on festivals as well. One of these is the prohibition against conducting a judicial procedure. 
Sabbath, they would not assemble on any other day." 40 According to the Palestinian halakhic text cited above, this lenient ruling was adopted in Palestine only in so far as Rosh Hashanah is concerned, presumably because the prohibition against dissolving vows on a festival is not explicitly mentioned in rabbinic literature. However, the petition of an individual for the dissolution of his vow is forbidden even on a festival, according to this text.

The manuscript in which this passage is found shows no traces of Babylonian influence. ${ }^{41}$ The text clearly indicates that in Palestine the dissolution of vows had developed into a public, communal affair by the sixth or seventh century. This is confirmed by an early Palestinian liturgical poem; which refers to the dissolution of vows on Yom Kippur, and other Palestinian halakhic material. ${ }^{42}$ Thus it is clear that the geonic reference to the custom in "other lands" refers to Palestine.

From the Palestinian text it would seem that the public Kol Nidre formula for the dissolution of vows was developed as an alternative to the individual's petition before a tribunal, since the latter was forbidden on Sabbaths and festivals.

It would therefore seem that the two customs mentioned at the beginning of this chapter were originally one and the same. The individual originally sought release from his vows on either Rosh Hashanah or Yom Kippur from a sage or a tribunal of three laymen, who subsequently granted absolution. This custom aroused opposition, since the dissolution of the vows of an individual on Sabbaths and festivals is forbidden. The solution was for the entire congregation to seek absolution together using the Kol Nidre formula. Y. D. Eisenstein, ${ }^{43}$ followed by Davidson, ${ }^{44}$ is probably correct in suggesting that originally the first part of Kol Nidre ("All vows...we regret all of them") was recited by the petitioners, while the second part ("All of them shall be permitted...the oaths are not oaths") was the response of the tribunal. This public recitation was permitted, since communal vows such as haramim could only be dissolved when the community assembled on Sabbaths and festivals, and personal vows were dissolved along with communal vows. At some later date an even better solution was found: Kol Nidre was recited in the synagogue shortly before the onset of Yom Kippur, when the congregation was assembled, but which is technically

\footnotetext{
${ }^{40}$ Ginzburg 1929:129. See also sources cited in Herr 1980:71, note 43.

${ }^{41}$ See Margaliot 1974:39. Herr 1980:70 cites this fact without comment, despite the fact that it would seem to contradict his central thesis.

${ }^{42}$ See I. Ta-Shma in Margaliot 1974:55, and also other Palestinian halakhic material cited there; Herr 1980:71 and sources cited there, notes 45-47.

${ }^{43}$ Eisenstein 1951, volume 5:275-276.

${ }^{44}$ Davidson 1923:188.
} 
weekday, making the dissolution of vows permissible without reservation. This is the custom today. ${ }^{45}$

\section{[2] Kol Nidre and the High Holy Days}

Palestine is thus the land in which Kol Nidre and the custom of absolving vows originated. But the question that puzzled scholars for generations remains: how did the dissolution of vows come to be associated with the high holy day season? Why, on the holiest day of the year, do we declare a blanket absolution of vows, without worrying about the moral implications? Indeed, why is such a blanket absolution necessary at all, and how does it work halakhically?

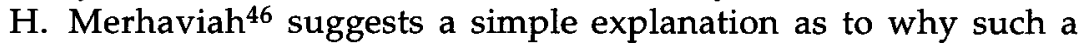
blanket absolution was considered necessary, and why it evolved in connection with the high holy day season. The high holy days are the season of repentance. According to the Rabbis, sincere repentance clears the slate of sins, but one can hardly repent a vow that one has not yet kept. We therefore absolve the votary of his vows so that he need not have any outstanding obligations on his conscience. The votary is not meant to subsequently ignore the vow. He must still make every effort to keep it. But on Yom Kippur he has a clean slate, since technical absolution has been granted on the eve of Yom Kippur.

The Palestinian halakhic text cited above indicates that the original custom was for the individual to seek absolution from specific vows from a sage or tribunal during the high holy day season, ${ }^{47}$ just as one seeks forgiveness from friends. Since many people probably approached the sage or convened a tribunal of laymen on the holidays themselves, when they were at leisure to do so and found themselves in the synagogue, and since the dissolution of individual vows is forbidden on festivals, the custom developed of absolving all the vows of the community together on the festival itself; individual vows were thus subsumed under the general absolution granted to the entire community using the Kol Nidre formula. ${ }^{48}$

\footnotetext{
${ }^{45}$ See the commentary of Asher ben Yehiel (Rosh) to Yoma; paragraph 28; Isserles' gloss to Shulhan Aruch Orah Hayyim 616:1 and commentators ad loc. 46 Merhaviah 1984:1062-1063.

${ }^{47}$ The reference is not to a public Kol Nidre formula, but to hatarat nedarim, which presumably consists of individual petitions (see Chapter 6 above). Thus the custom first described by Isaiah Horowitz in seventeenth-century Palestine (see above note 2) may in fact be a continuation of the original Palestinian custom. ${ }^{48}$ Another possibility is that the public absolution dates from the seventh century, and is a polemic against the Karaite opposition to the dissolution of vows. Those who objected to the theory of Poznanski and Krauss that Kol Nidre is a polemic against the Karaites (see above, section 1) point out that the dissolution of vows
} 
However, we must still address the question of the halachic validity of communal absolution, or even a blanket absolution of the vows of an individual. According to the dominant halakhic approach, neither of these forms of absolution is valid. One can be released from a vow only on real "grounds;" under normal circumstances, a vow is always binding. If these customs have no halakhic validity whatsoever, it is hard to understand how they evolved, even as a mere precautionary measure of achieving a clean slate.

However, "grounds" are a sine que non for absolution only according to one of the approaches discussed in the previous chapter. ${ }^{49}$ According to the other approach, sages are not mere consultants who find grounds for annulling the vow $a b$ initio; the sages have the power to annul vows whenever they see fit to do so. They act as agents for the Temple, "rejecting" the offering made in connection with the vow. ${ }^{50}$ It would seem that the custom of granting blanket absolution to vows is valid according to this approach. Although normally a sage would annul a vow only after a personal interview, and only if he is convinced that the sincere regret of the votary or changed circumstances render annulment warranted, he could theoretically annul any vow. Since on Yom Kippur it is clear that the annulment is not meant to release the votary from his obligation, but only to create an atmosphere of moral purity upon which no outstanding obligations impinge, it is assumed that the "regret" is sincere, even if the votary offers no reasons or explanations or sign of a change of heart.

It is not necessary to assume that the circles in which the custom of granting blanket absolution from vows on the high holy days actually adopted this second approach to the dissolution of vows. In fact, it is clear from the fact that oaths are included in the Kol Nidre formula that the author of the formula was unaware of the cultic basis of this conception of annulment, since, as we saw in the previous chapter, ${ }^{51}$ this view cannot explain the annulment of oaths, which are included in Kol Nidre. However, it is customary before Yom Kippur to take any and all measures to purify oneself, even if the chances are slim that these measures are halakhically valid. Thus it is customary to immerse in a mikveh on the day before Yom Kippur, despite the fact that a mikveh alone is insufficient to remove most types of impurity to which males are

during the high holy days is clearly an earlier phenomenon (see above, note 10); it may be, however, that the earlier custom involved individual petitions for absolution, but the custom of publicly absolving the entire congregation can still be considered a response to Karaism.

${ }^{49}$ See above, Chapter 6 , sections 1 and 5 .

50 See above, Chapter 6 , sections 2,3 , and 5 .

${ }^{51}$ See above, Chapter 6 , section 5 . 
susceptible. ${ }^{52}$ These customs can be compared to the measures taken with regard to leaven before Passover: the house is purged of leaven, and nonetheless the search for leaven takes place, followed by the burning of the leaven and the declaration that any and all leaven found in one's home is no longer one's property, and also that the leaven is tantamount to dust; all of which are usually accompanied today by the sale of any and all leaven found in one's home to a gentile for the duration of Passover. ${ }^{53}$

The Geonim nonetheless objected to the custom of dissolving vows with the Kol Nidre formula on ethical and halakhic grounds, since it was generally conceded that a sage could annul a vow only if he found proper grounds for annulment $a b$ initio. ${ }^{54}$ Hai Gaon therefore emended Kol Nidre so that it became a prayer to God to overlook vows that were not kept. ${ }^{55}$ Meir ben Samuel of eleventh-century France, on the other hand, rather carelessly emended the formula so that it became a declaration that the vows of the coming year were not to be considered binding, on the basis of BT Nedarim 23a. ${ }^{56}$ At this point, some reverted to the original custom of having the individual petition a tribunal of three for blanket absolution on a weekday during the high holy day season. ${ }^{57}$ This is only slightly preferable, from the halakhic point-of-view, to Kol Nidre: no reasons for the change of heart are proffered by the petitioner, and blanket absolution is still granted for all vows.

Nonetheless, all forms of absolution connected with the high holy day season become comprehensible when seen in context, as an attempt to enter Yom Kippur with a clean slate and a pure heart. The petitioner and the congregation are not expected to take advantage of Kol Nidre by reneging on oaths and vows; they merely wish to take all precautions in order to enter Yom Kippur with no outstanding obligations. In the words of Merhaviah:

The preparations for the Day of Judgment and one's behavior on the Day of Judgment not only aim to achieve atonement, but also self-improvement to the point of perfection, and self-purification to the point of catharsis. The customs are many and well-known: immersion...confession...absolution of vows...repentance...seeking forgiveness from others...appeasement...repayment of debts...selfdenial (even flagellation)...the slaughter of a rooster or hen as a

\footnotetext{
${ }^{52}$ See commentary of Elijah Gaon of Vilna to Orah Hayyim 606:4.

${ }^{53}$ See Shulhan Aruch Orah Hayyim 434:2; 448:3, and Magen Avraham ad loc.

${ }^{54}$ See Herr 1980:73-75 and citations there.

${ }^{55}$ See references above, note 4 .

56 See above, section 1 , and references cited above, note 25 .

${ }^{57}$ See above, note 2 . But perhaps this is merely a continuation of the original custom; see above, note 47 .
} 
form of vicarious atonement...memorial candles, white clothes, walking barefoot, and, of course, almsgiving, prayer, and fasting.

Kol Nidre is the last attempt at achieving purity and catharsis, after all other means and measures have been taken for the resolution of outstanding issues between man and God and between man and his fellow man. Kol Nidre cements the last crack in the personal defense system.... Only an unconditional declaration of absolution can create an atmosphere of festive sanctification, but the existing restrictions are in no way undermined...Even the excommunicated will revert to their excommunication after Yom Kippur, but on the day itself they are not prohibited from participating in the services. The day of reckoning and judgment thus becomes the day of faith and hope. ${ }^{58}$

${ }^{58}$ Merhaviah 1984:1062-1063. 


\section{Bibliography}

\section{Albeck 1959}

סדר נשים, מתוך: ששה סדרי משנה מפורשים כירי חגוך אלבק, ירושלים ותל-אביב חשי״ט. Albeck 1960

ש אלבק, "יסודות משסר הקהילות בספרד עד הרמ"ה", ציון כה (תש"ך), עמ' 85-121.

\section{Allegro 1956}

J. M. Allegro, "Further Light on the History of the Qumran Sect," Journal of Biblical Literature 75 (1956), pp. 89-95.

Allen 1907

W. C. Allen, A Critical and Exigetical Commentary on the

Gospel According to S. Matthew (International Critical

Commentary), Edinburgh 1907.

\section{Amit 1992}

" אמית, ספר שופטים - אמנוח העריכה, ירושלים חשנ"ב.

\section{Arndt and Gingrich 1952}

W. F. Arndt and F. W. Gingrich, A Greek-English Lexicon of the

New Testament and other Early Christian Literature, Chicago and Cambridge 1952.

Avishur 1979

$$
\text { " אבישור, כתובות פיקיות והמקרא, כרך ב', ירושלים חשל״,. }
$$

Azar 1981

$$
\text { מ' אזר, לשונות החחייבות במקרא ובמשנה, חיפה תשמ"א. }
$$

\section{Baer 1950}

י יכער, "ההתחלות והיסודות של ארגון הקהילות היהודיות בימי הבינים", ציון טו (תש״י), עמ'1-41.

\section{Baer 1966}

" בער, "לבעיית דמותה של היהדות באבנגלינים הסינאופטיים", ציון לא (תשכ"ו), עמ' 117-152. 


\section{Baumgarten 1984-85}

A. I. Baumgarten, "Korban and the Pharisaic Paradosis," Journal of the Ancient Near Eastern Society of Columbia University 16-17 (198485) (E. Bickerman Memorial Volume), pp. 5-17.

\section{Behm 1964}

J. Behm, "Anathema," Theological Dictionary of the New Testament, volume 1, Grand Rapids, MI 1964.

\section{Belkin 1940}

S. Belkin, Philo and the Oral Law, Cambridge MA 1940.

\section{Benovitz 1993}

מ' בנוביץ, פירוש מדעי לפרק שבועות שחים בתרא בכבלי (ריסרטציה), ניו יורק תשצ'ג.

Benovitz 1995

מ' בנוביץ, "נדר האיסור בימי הבית השגי ובספרות התנאים: מוצאו ומשמעו", תרביץ סד (תשנ"ה), עמ' 203-228.

Benovitz 1996

$$
\text { מ' בנוביץ, "כל כינויי נדרים", סידרא יב (תשנ׳י), עמ' 5-25. }
$$

\section{Bickerman 1950}

E. Bickerman, "The Date of the Testaments of the Twelve

Patriarchs," Journal of Biblical Literature 69 (1950), pp. 245-260.

\section{Biella 1982}

J. C. Biella, Dictionary of Old South Arabic: Sabaen Dialect (Harvard Semitic Studies 25), Chico CA 1982.

\section{Birnbaum 1951}

P. Birnbaum, translator and editor, High Holyday Prayer Book, New York 1951.

\section{Bloch 1922}

J. S. Bloch, Kol Nidre und seine Enstehungsgeschichte, third edition, Berlin 1922.

\section{Bokser 1987}

B. M. Bokser, "Todos and Rabbinic Authority in Rome," in Religion, Literature and Society in Ancient Israel I (1987), pp. 117130.

\section{Bowman 1965}

J. Bowman, The Gospel of Mark: The New Christian Jewish Passover Haggadah, Leiden 1965. 


\section{Breuer 1987}

" ברויאר, "על לשון העברית של הטמוראים בתלמוד הבבלי", מחקרים בלשון ב-ג (תשמ"ז), עמ'

\section{Broshi 1992}

M. Broshi, editor, The Damascus Document Reconsidered, Jerusalem 1992.

\section{Buchanan 1965}

G. W. Buchanan, "Some Vow and Oath Formulas in the New

Testament," Harvard Theological Review 58 (1965), pp. 319-326.

\section{Buechler 1895}

A. Buechler, Die Priester und der Cultus im letzten Jahrzehnt des jerusalmischen Tempels, Vienna 1895.

\section{Buechler 1901}

A. Buechler, "Le Dositheens dans le Midrasch," part 2, Revue des Etudes Juives 43 (1901), pp. 50-71.

Cassuto 1969

$$
\text { מ"ר קסושו, פירוש על ספר בראשית, ירושלים חשכ"ט. }
$$

\section{Childs 1974}

B. S. Childs, The Book of Exodus (Old Testament Library), Phildelphia 1975.

\section{Cohn 1971}

H. H. Cohen, "Herem. In Later Jewish Law," Encyclopedia Judaica, volume 8, Jerusalem 1971.

\section{Colson 1941}

F. H. Colson, translator and editor, Philo (Loeb Classical Library), volume 9, Cambridge MA 1941.

\section{Conzelmann 1975}

H. C. Conzelmann, I Corinthians (Hermenia), Philadelphia 1975.

\section{Cooke 1903}

G. A. Cooke, A Text-Book of North Semitic Inscriptions, Oxford 1903.

\section{Crawley 1917}

A. E. Crawley, "Oath," The Encyclopedia of Religion and Ethics, volume 9, Edinburgh and New York 1917.

\section{Cross and Livingstone 1974}

F. L. Cross and E. A. Livingstone, editors, The Oxford Dictionary of the Christian Church, second edition, Oxford 1974. 


\section{Dalman 1894}

G. H. Dalman, Grammatik des juedisch-palaestinischen Aramaeisch, Leipzig 1894.

\section{Dalman 1896}

G. H. Dalman, Aramaeische Dialektproben, Leipzig 1896.

\section{Daniel-Nataf 1986}

ס' דניאל נטף, עורכת, פילון האלכסנדרוני, כתבים, כרך א', ירושלים חשמ"ו.

\section{Davidson 1923}

J. Davidson, "Kol Nidre," American Jewish Yearbook 5684, 25

(1923), pp. 180-194.

\section{Davidson 1929}

" דאווידזאן, אוצר השירה והפיוט, כרך ב', ניו יורק תרפ״ט.

\section{Davies 1983}

P. R. Davies, The Damascus Covenant, Sheffield 1983.

\section{Derret 1969-70}

J. Duncan M. Derret, "KORBAN, HO ESTIN DORON," New

Testament Studies 16 (1969-1970), pp. 364-368.

\section{Derret 1983}

J. Duncan M. Derret, “'Behuqey Hagoyim,' Damascus Document IX,1, Again," Revue de Qumran 11 (1982-1984), pp. 409-415.

\section{Deshen 1980}

$$
\begin{aligned}
& \text { שי דשן, "חידת כל גדרי: בירור אגתרופולוגי והיסטורי", }
\end{aligned}
$$

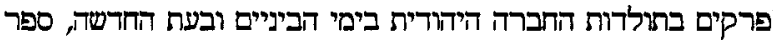

$$
\begin{aligned}
& \text { היובל ליעקב כ"ץ, ירושלים חש"ם, עמ' קלו-קנג. }
\end{aligned}
$$

De Vries 1968

$$
\text { ב' דה-פריס, מחקרים בספרות התלמד, ירושלים תשכ"ח. }
$$

\section{Donner and Roellig 1964}

H. Donner and W. Roellig, Kanaanaeische und Aramaeische Inschriften, Wiesbaden 1964.

\section{Driver 1913}

S. R. Driver, Notes on the Hebrew Text of the Books of Samuel, Oxford 1913.

\section{Driver 1967}

G. R. Driver, "Hebrew Homonyms," Hebraeische Wortforschung (Supplements to Vetus Testamentum 16), 1967, pp. 50-64. 


\section{Edersheim 1873}

A. Edersheim, The Temple, its Ministry and Services, London 1873.

\section{Efrati 1973}

" אפרתי, "למקורות הספרותיים השקועים במשנתנו", בר אילן יא (תשל'צ), עמ' 49-68.

\section{Efron 1987}

J. Efron, Studies on the Hasmonean Period, Leiden 1987.

Ehrentreu 1912

H. Ehrentreu, "Sprachliches und Sachliches aus dem Talmud," Jahrbuch der juedisch-literarischen Gesellschaft 10 (1912), pp. 193197.

\section{Eilberg-Schwartz 1986}

H. Eilberg-Schwartz, The Human Will in Judaism: The Mishna's

Philosophy of Intention, Atlanta 1986.

Eisenstein 1951

$$
\text { י"ד אייענשסיין, אוצר ישראל, כרך ה', ניי יורק חשי״ב -1951. }
$$

Eissfeldt 1935

O. Eissfeldt, Molk als Opferbegriff im Punischen und Hebraeischen, Halle 1935.

Epstein 1938

$$
\text { י״נ, אפשטיין, "ללשון גזירות", ספר מננס, ירושלים תרצ"ח, עמ' 10-16. }
$$

Epstein 1948

$$
\text { ינין אפשטיין, מבוא לנוסח המשנה, ירושלים תש"ח. }
$$

Epstein 1957

ייף אפשטיין, מבואות לספרוח התנאים, ירושלים וחל אביב תשייז.

Epstein 1963

י"ב אפשטיין, מבואות לספרות האמראים, ירושלים ותל אביב חשכ"ג.

Falk 1966

Z. W. Falk, "On Talmudic Vows," Harvard Theological Review 59 (1966), pp. 309-312.

\section{Falk 1967}

Z. W. Falk, "'Behuqey Hagoyim' in Damascus Document IX,1,"

Revue de Qumran 6 (1967-1969), p. 569.

Finkelstein 1962

L. Finkelstein, The Pharisees, Philadelphia 1962. 
Fitzmyer 1959

J. M. Fitzmyer, "The Aramaic Qorban Inscription from Jebel Hallet et-Turi and Mark 7:11//Matt 15:8, Journal of Biblical Literature 78 (1959), pp. 60-65.

\section{Fraenkel 1898}

S. Fraenkel, Review of S. Krauss, Griechische und lateinische Lehnwoerter in Talmud, Midrasch und Targum, Zeitschrift der Deutschen Morgenlaendischen Gesellschaft 52 (1898), pp. 290-300.

\section{Frankel 1994}

ד' פרנקל, סיפורי התלונה במרבר על פי האסכולה הכהנית" (דיסרטציה), ירושלים תשנ"ד.

Friedman 1991

ש״יי פרידמן, תלמוד ערוך, השוכר את האומנין, הפירושים, ירושלים תשנ״א.

Friedman 1992

ש״יי פרידמן, "תיקוני ערכים למילון התלמודי (ד): אמדא", מחקרים בלשון דהו (תשנ״ב), עמ' .327-345

Friedrich 1951

J. Friedrich, Phoenizisch-punische Grammatik, Analecta Orientalia 32, Rome 1951.

Gibson 1982

J. C. L. Gibson, Textbook of Syrian Semitic Insriptions, volume 3, Oxford 1982.

\section{Gilat 1992}

ייד גילת, פרקים בהשתלשלות ההלכה, רמת גן תשנ"ב.

Ginzburg 1929

$$
\text { ל' גינצבורג, עורך, גני שכטר, ספר ב', ניו יורק תרפ״ס. }
$$

Goldschmidt 1970

ר' גולדשמידט, מחזור לימים הנוראים, כרך ב': יום כיפור, ירושלים תשי', מבוא.

Goodblatt 1987

D. Goodblatt, "Agrippa I and Palestinian Judaism in the First Century," Jewish History 2 (1987), pp. 7-32.

\section{Gordon 1966}

C. H. Gordon, "Leviathan, Symbol of Evil," in Biblical Motifs, Cambridge MA 1966, pp. 1-9. 


\section{Gould 1896}

E. P. Gould, A Critical and Exegetical Commentary on the Gospel According to St. Mark (International Critical Commentary), Edinburgh 1896.

\section{Gray 1964}

J. Gray, I and II Kings (Old Testament Library), London 1964.

\section{Green 1979}

W. S. Green, "Rabbinic Holy Men," in Aufsteig und Niedergang der roemischen Welt II 19/2 (1979), pp. 619-648.

\section{Greenberg 1957}

M. Greenberg, "The Hebrew Oath Particle HAY/HE," Journal of Biblical Literature 76 (1957), pp. 34-39.

\section{Greenberg 1971}

M. Greenberg, "Herem. In the Bible," Encyclopedia Judaica, volume 8, Jerusalem 1971.

\section{Greenberg 1983}

M. Greenberg, Ezekiel 1-20 (Anchor Bible), Garden City NY 1983.

\section{Greenfield 1976}

J. C. Greenfield, Review of Essays on the Semitic Background of the Old Testament by J. A. Fitzmyer, Journal of Near Eastern Studies 35 (1976), pp. 59-61.

\section{Halevy 1906}

$$
\text { י"א הלוי, דורות ראשונים, תלק א', כרך ג', פרנקפורט תרס"ו. }
$$

\section{Halper 1915}

B. Halper, A Volume of the Book of Precepts, Philadelphia and

Oxford 1915.

\section{Haran 1968}

$$
\text { מ' הרן, "נדריז, אנציקלופדיה מקראית, כרך ה', ירושלים תשכ"ח. }
$$

Haran 1978

M. Haran, Temples and Temple Service in Ancient Israel, Oxford 1978.

\section{Haran 1979}

M. Haran, "The Law Code of Ezekiel XL-XLVIII and its Relation to the Priestly School," Hebrew Union College Annual 50 (1979), pp. 45-72. 
Harris 1939

Z.S. Harris, The Development of the Canaanite Dialects, New Haven CT 1939.

Hart 1907

J. H. A. Hart, "Corban," Jewish Quarterly Review (Old Series) 19 (1907), pp. 615-650.

Hauck 1972

F. Hauck, "Koinos," Theological Dictionary of the New Testament, volume 3, Grand Rapids 1972.

Herr 1980

מ"ד הר, "ענייני הלכה בארץ ישראל במאה הששית והשביעית לספירת הנוצרים", תרביץ מט

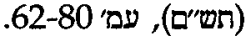

Hershler 1985

מ' הרשלר, עורך, תלמור בבלי מסכת נדרים עם "רקדוקי סופרים השלם", כרך א', ירושלים תשמ"ה.

Hoftijzer and Jongeling 1995

J. Hoftijzer and K. Jongeling, Dictionary of the North-west Semitic Inscriptions, Leiden 1995.

Kaufman 1974

S. Kaufman, The Akkadian Influences on Aramaic, Chicago 1974.

Kaufmann 1929

" קויפמן, גולה ונכר, חל אביב תרפ״ם.

Klausner 1927

" קלוזנר, ישו הנוצרי: זמנו, חייו, ותורהו, מהדורה שנייה, ירושלים-ורשה תרפ־ז.

Klein 1939

שי קליין, ספר היישוב, כרך אי, ירושלים תרצ׳ם.

Klostermann 1926

E. Klostermann, Das Marcusevangelium, Tuebingen 1926.

Koehler 1928

L. Koehler, "Eid," Die Religion in Geschichte und Gegenwart, volume 2, Tuebingen 1928.

Krauss 1898-99

S. Krauss, Griechische und lateinische Lehnwoerter in Talmud, Midrasch und Targum, mit Bemerkungen von I. Loew, Berlin 1898-1899. 


\section{Krauss 1928}

S. Krauss, "Das Problem Kol Nidre," Jahrbuch der juedischliterarischen Gesellschaft 19 (1928), pp. 85-97.

\section{Kuhn 1990}

H. W. Kuhn, "Anathema," Exegetical Dictionary of the New Testament, Edinburgh 1990.

Kutscher 1970

$$
\text { י קוסשר, "חי פרעה", ספר שמואל ייבין, ירושלים תשיל, עמ' 460-461. }
$$

Kutscher 1975

$$
\text { הח קופשר, "מצב דמחיקר של לשון דזו"ל (בעיקר במילוטאות) ותפקידיו", ערכי המילון }
$$

Lane 1863-1893

E. W. Lane, An Arabic-English Lexicon, London 1863-1893.

\section{Lehmann 1969}

M. R. Lehmann, "Biblical Oaths," Zeitschrift fuer die

alttestamentliche Wissenschaft 81 (1969), pp. 74-92.

\section{Leibson 1975}

$$
\text { ג' ליבזון, "על מה מנדין ?", שנתן המשפט העברי ב (חסל״"), עמ' 292-342. }
$$

\section{Leibson 1979-80}

ג' ליבזון, ינידוי ומנודה בעיני ודתנאים והאמוראים", שנתון המשפם העברי ו-ז (תמל״ם-תש״ם), עמ'

\section{Levenson 1976}

J. D. Levenson, The Theology of the Program of Restoration of Ezekiel 40-48, Missoula 1976.

Levias 1933

$$
\text { ק' לויאט, ״מיולים בשדה הלשון", לשוננו ה (תרצ׳ג) ,עמ׳ 205-220. }
$$

Levine 1974

B. A. Levine, In the Presence of the Lord, Leiden 1974.

Levine 1989

B. A. Levine, Leviticus (JPS Torah Commentary), Philadelphia, New York, and Jerusalem 1989.

\section{Lewin 1942}

$$
\text { ב־מם לוין, עורך, אוצר הגאונים, כרך יא, נדרים, ירושלים תש"ב. }
$$

\section{Liddel and Scott}

H. G. Liddel and R. Scott, A Greek-English Lexicon, Oxford 1940. 


\section{Lichtenstein 1931-32}

H. Lichtenstein, "Die Fastenrolle....מילח תענית," Hebrew Union College Annual 8-9 (1931-32), pp. 257-351.

Lieberman 1937-39

$$
\text { שי ליברמן, תוספת ראשונים, ירושלים תרצ"ז-תרצ״". }
$$

\section{Lieberman 1942}

S. Lieberman, Greek in Jewish Palestine, New York 1942.

\section{Lieberman 1955}

ש' ליברמן, תוספתא כפשופה, זרעים, ניו יורק תשט"ו.

Lieberman 1962

$$
\text { שי ליברמן, תוספחא כפשופה, מועד, ניו יורק תשכ"ב. }
$$

Lieberman 1963

$$
\text { שי ליברמן, יוונית ויוונות בארץ ישראל, ירושלים תשכ"ג. }
$$

Lieberman 1967

$$
\text { ש' ליברמן, תוספתא כפשוטה, נשים, ניו יורק תשכ״י. }
$$

Lieberman 1968

$$
\text { שי ליברמן, ספרי זוטא (מדרשה של לוד), ניו יורק תשכ"ח. }
$$

Lieberman and Kutscher 1963

שי ליברמן ויי קוטשר, "חרגין, חרמין ותגרין, לשונני כז (תשכ"ג), שמ' 34-39.

Lightfoot 1859

J. Lightfoot, Commentary on the New Testament from the Talmud and Hebraica, Oxford 1859.

\section{Lizbarski 1902-1915}

M. Lizbarski, Ephemeris fuer semitische Epigraphik, Giessen 19021915.

\section{Loew 1924-1934}

I. Loew, Die Flora der Juden, Vienna 1924-1934.

Loewenstamm 1976

שיא ליונשטם, "שכועה", אנציקלופדיה מקראית, כרך ז', ירושלים חשל"ז.

\section{Lohfink 1986}

N. Lohfink, "חרם," Theological Dictionary of the Old Testament, volume 1, Grand Rapids, MI 1986.

\section{McCarter 1980}

P. K. McCarter, Jr., I and II Samuel (Anchor Bible), Garden City NY 1980. 


\section{Malamat 1961}

א' מלמט, "החרם במארי ומקרא", ספר היובל ליחקאוא קויפמן, ירושלים חשכ׳א.

Mann 1917

J. Mann, "Oaths and Vows in the Synoptic Gospels," American Journal of Theology 21 (1917), pp. 260-274.

Mann 1972

J. Mann, Texts and Studies, volume 2, reprinted with new matter, New York 1972.

Manson 1943

T. W. Manson, The Teaching of Jesus, Cambridge 1943.

Margaliot 1974

מ׳ מרגליות, הלכות ארץ ישראל מן הגניזה, ירושלים תשלי״.

Merhaviah 1984

ח' מרחביה, "כל נדרי - בין בעיה לחידה", ספר היובל לגריי״ד סולוביציק, ירושלים וניו יורק תשמ"ר, עמ' תתרנו-תחרצו.

\section{Milgrom 1976}

J. Milgrom, Cult and Conscience, Leiden 1976.

\section{Milgrom 1981}

J. Milgrom, "Sancta Contagion and the Altar/City Asylum,"

Supplements to Vetus Testamentum 32 (1981), pp. 278-310.

\section{Milgrom 1990}

J. Milgrom, Numbers (JPS Torah Commentary), Philadelphia,

New York, and Jerusalem 1990.

\section{Milgrom 1991}

J. Milgrom, Leviticus 1-16 (Anchor Bible), New York 1991.

\section{Milik 1976}

J. T. Milik, The Books of Enoch, Oxford 1976.

\section{Montefiore 1968}

C. G. Montefiore, The Synoptic Gospels, volume 1, second edition, New York 1968.

Moore 1927

C. F. Moore, Judaism in the First Centuries of the Christian Era, Cambridge 1927.

Moulton and Milligan 1930

J. H. Moulton and G. Milligan, The Vocabulary of the Greek

Testament, London 1930. 


\section{Murphy-O'Connor 1972}

J. Murphy-O'Connor, "A Literary Analysis of Damascus

Document XIX,33 - XX,34," Revue Biblique 79 (1972), pp. 544-564.

\section{Naveh and Shaked 1993}

J. Naveh and S. Shaked, Magic Spells and Formulae: Aramaic Incantations of Late Antiquity, Jerusalem 1993.

Neusner 1973

J. Neusner, Eliezer ben Hyrcanus: The Traditions and the Man, Leiden 1973.

Niditch 1993

S. Niditch, War in the Hebrew Bible: A Study in the Ethics of

Violence, New York and Oxford 1993.

\section{Noth 1968}

M. Noth, Numbers (Old Testament Library), London 1968.

Pardee 1995

N. Pardee, "The Curse that Saves (Didache 16.5)," Supplements to Novum Testamentum 77 (1995), pp. 156-176.

Pease 1935

A. S. Pease, editor, Aeneidos Liber IV, Cambridge MA 1935.

Pedersen 1914

J. Pedersen, Der Eid bei den Semiten, Strassbourg 1914.

Porat 1938

א' פורת, לשון חכמים, ירושלים תרצ׳"ח.

Pouilly 1975

J. Pouilly, "L'evolution de la legislation penale dans le communaute de Qumran," Revue Biblique 92 (1975), pp. 522551.

Poznanski 1918

S. Poznanski, Eine neue Hypothese ueber die Entstehung des Kol

Nidre, Vienna 1918.

\section{Pritchard 1969}

J. B. Pritchard, Ancient Near Eastern Texts Relating to the Old

Testament, Princeton 1969.

\section{Qimron 1994}

א' קימרון, "קובץ חרש של כתובות ותעודות קדומות", לשוננו ני (תשכ"ד), עמ'267-272. 


\section{Rabin 1958}

C. Rabin, editor, The Zadokite Documents, second edition, Oxford 1958.

\section{Rabinowitz 1967}

S. Rabinowitz, "The Meaning and Date of 'Damascus' Document IX,1," Revue de Qumran 6 (1967-1969), pp. 433-435.

Rabinowitz 1972

צ׳מ רבינוביץ, "ספר המעשים לבני ארץ ישראל, שרידים חדשים", תרביץ מא (חשל״ב), עמ' .275-305

Reeg 1989

G. Reeg, Die Ortsname Israels nach der rabbinischen Literatur, Wiesbaden 1989.

\section{Rendsburg 1992}

G. A. Rendsburg, "The Galilean Background of Mishnaic Hebrew," in The Galilee in Late Antiquity, edited by L. I. Levine, New York and Jerusalem 1992, pp. 225-240.

\section{Rengstorf 1965}

K. H. Rengstorf, "korban, korbanas," Theological Dictionary of the

New Testament, volume 3, Grand Rapids MI 1965.

\section{Rosenthal 1952}

F. Rosenthal, Review of Johannes Friedrich's Phoenizisch-punische Grammatik, Journal of the American Oriental Society 72 (1952), pp. 171-173.

\section{Rosenthal 1993}

א"ש רוזנטל, "בירורי מלים ועיוני נוסח', מחקרי תלמד ב', ירושלים תשנ״ג, עמ' יג-מו. Rost 1933

L. Rost, editor, Das Damaskusschrift, Berlin 1933.

San Nicolo 1938

M. San Nicolo, "Eid," Reallexikon fuer Assyrologie, volume 2,

Berlin and Leipzig 1938.

\section{Sarfatti 1957}

גב'ע צרפתי, "חסידים ואגשי מעשה והנביאים הראשונים", תרביץ כו (תש"ז), עמ' 125-153.

\section{Schechter 1970}

S. Schechter, editor, Documents of Jewish Sectaries, second edition, New York 1970. 
Schiffman 1983

L. H. Schiffman, Sectarian Law in the Dead Sea Scrolls, Chico CA 1983.

\section{Schiffman 1991}

L. H. Schiffman, "The Law of Vows and Oaths in the Zadokite Fragments and the Temple Scroll," Revue de Qumran 15 (1981), pp. 199-214.

\section{Schuerer-Vermes-Millar 1973-1987}

E. Schuerer, A History of the Jewish People in the Age of Jesus Christ, Edinburgh 1973-1987.

\section{Segal 1928-1929}

מ״צ סגל, "לבניית פסוקי השבועה והנדר בעברית", לשוננו א (תרפ״ח-תרפ״ט), עמ'215-277.

\section{Segert 1976}

S. Segert, A Grammar of Phoenician and Punic, Munich 1976.

\section{Smith $\mathbf{1 8 9 0}$}

W. Smith, Dictionary of Greek and Roman Antiquities, London 1890.

\section{Smith 1966}

H. W. Smith, Greek Grammar, Cambridge MA 1966.

\section{Sperber 1984}

D. Sperber, Greek and Latin Legal Terms in Rabbinic Literature, Ramat Gan 1984.

\section{Spiegel 1969}

S. Spiegel, The Last Trial, New York 1967.

\section{Stade 1875}

B. Stade, "Erneuete Pruefung des zwischen dem Phoenicischen und Hebraeischen bestehenden Verwandtschaftsgrades," Morgenlaendischen Forschungen, Leipzig 1875, pp. 167-232.

\section{Stegemann 1963}

H. Stegemann, "Der Pesher Psalm 37," Revue de Qumran 4 (19631964), pp. 235-270.

\section{Stern 1974}

M. Stern, Greek and Latin Authors on Jews and Judaism, volume 1, Jerusalem 1974.

Stern 1976

$$
\text { א' שטרן, "קבר, קבורה", אנציקלופריה מקראית כרך ז', ירושלים תשל"ו. }
$$




\section{Stern 1991}

P. D. Stern, The Biblical Herem, Atlanta 1991.

Stone 1991

M. E. Stone, Selected Studies in Pseudepigrapha and Apocrypha, Leiden 1991.

Strack and Billerbeck 1922

H. L. Strack and P. Billerbeck, Kommentar zum neuen Testament, Munich 1922.

\section{Taylor 1965}

V. Taylor, The Gospel According to St. Mark, London and Basingstoke 1965.

\section{Torrey 1912}

C. C. Torrey, "New Notes on Some Old Inscriptions," Zeitschrift fuer Assyrologie 26 (1912), pp. 83-84.

Torrey 1937

C. C. Torrey, "A New Phoenician Grammar," Journal of the American Oriental Society 57 (1937), pp. 407-408.

\section{Tur-Sinai 1956}

$$
\text { נ״״ה טור-סיני, הלשון והספר, כרך ג', ירושלים תשט״ז. }
$$

\section{Urbach 1986}

א"א אורבך, ההלכד: סקורותיה והתפחחותה, גבעתיים תשמ"ד.

\section{Von Rad 1962}

G. von Rad, Old Testament Theology, Edinburgh and London 1962.

\section{Wasserstein 1993}

A. Wasserstein, "A Note on the Phonetic and Graphic Representation of Greek Vowels and of the 'Spiritus Asper' in the Aramaic Transcription of Greek Loanwords," Scripta Classica Israelica 12 (1993), pp. 200-208.

\section{Weinfeld 1972}

M. Weinfeld, "The Worship of Molech and the Queen of Heaven and its Background," Ugarit Forschungen 4 (1972), PP. 133-154.

\section{Weinfeld 1975}

M. Weinfeld, "Berit - Covenant vs. Obligation," Biblica 56 (1975), pp. 120-128. 


\section{Weinfeld 1986}

M. Weinfeld, The Organizational Pattern and Penal Code of the

Qumran Sect, Fribourg 1986.

\section{Weinfeld 1993}

M. Weinfeld, The Promise of the Land, Berkeley 1993.

Wellhausen 1903

J. Wellhausen, Das Evangelium Marci, Berlin 1903.

Wieder 1978

נ' וידר, "עבר ועתיד בנוסח כל נדרי", מכתם לדוד (ספר זכרון הרב ר' אוקס ז״ל), רמת גן

חשל"ח, עמ' בער ושיר ה189-209.

\section{Wilson 1948}

J. A. Wilson, "The Oath in Ancient Egypt," Journal of Near Eastern Studies 7 (1948), pp. 129-156.

Winter 1967

P. Winter, "Sadoqite Fragments IX,1," Revue de Qumran 6 (19671969), pp. 131-136.

Wuensche 1878

A. Wuensche, Neue Beitraege zur Erlaueterung der Evangelien aus Talmud und Midrasch, Goettingen 1878.

Yadin 1983

Y. Yadin, The Temple Scroll, Jerusalem 1983.

Yaffin-Ritba appendix 1977

מילואים, בסוף חידושי הרימב"א, מסכת נדרים, מהדורת הרב אהרן יפה'ן, ירושלים תשצ'ג. 


\section{Index of Citations}

\begin{tabular}{|c|c|}
\hline le & 33 \\
\hline & 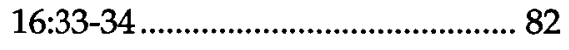 \\
\hline .......90 & $17: 12 \ldots \ldots \ldots . .$. \\
\hline ......... 92 & 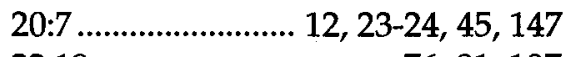 \\
\hline ........ 53 & 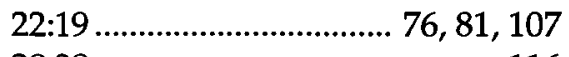 \\
\hline .......8 & $28: 28$ \\
\hline$\ldots 88$ & $30: 16$ \\
\hline$\ldots . . .88$ & 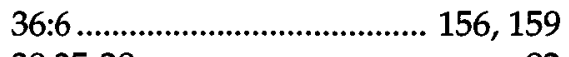 \\
\hline .88 & $38: 25-28$ \\
\hline$\ldots . . .88$ & Levitic \\
\hline ..............88 88 & 45 \\
\hline$\ldots . .88$ & $5: 14-16 \ldots \ldots \ldots \ldots$ \\
\hline$\ldots . . .88$ & 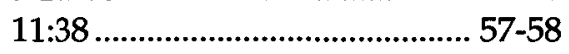 \\
\hline$\ldots . . .88$ & 82 \\
\hline .... 88 & 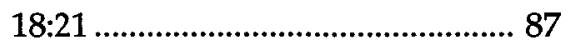 \\
\hline. .88 & 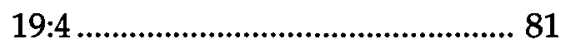 \\
\hline$\ldots 88$ & 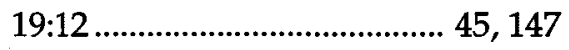 \\
\hline ...... 9 & 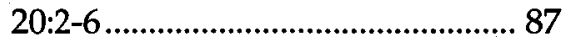 \\
\hline 77 & .................................. \\
\hline 7 & 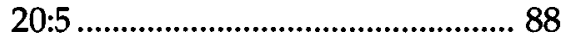 \\
\hline 2 & 71 \\
\hline 132 & 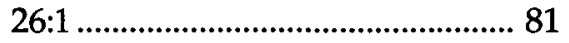 \\
\hline$\ldots 80$ & $77,82-84,102,1$ \\
\hline .. 127 & ................ \\
\hline 80 & 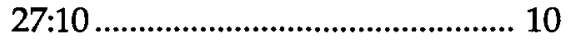 \\
\hline$F x$ & (1) \\
\hline .... 128,130 & .................................. \\
\hline ........... 115 & $27: 28 \ldots \ldots \ldots \ldots \ldots . . \ldots 9,74,83-87,90-92$ \\
\hline$\ldots 115$ & …..................94, 101, 1 \\
\hline & ........... \\
\hline & \\
\hline
\end{tabular}


Numbers

$31: 29$.......................................... 82

6:1-21

$931: 30$

$15: 20$

$8531: 41$

$16: 14$

16:32

$31: 47$

17:1-5

78

31:50

$17: 5$

$17: 25$

82

18 83-86

18:7

78

18:9-10

.. 847

82

18:9

$84 \quad 7: 25-26$ 80

18:11-19

$84 \quad 7: 26$ 80

18:11

$18: 13$

85

85

18:14 $75,84-86,108$

10:20 128

18:19

85

21:1-3

72

21:2-3

72

21:3

75

25:1-5

76

$12: 30-31$

...79

25:4

$81 \quad 14: 3$

79-80

25:7

81

30

$3,9-10,12,40-45,52$

$13: 5$ .. 80 $56,59-62,64,68$

30:3-15

.. 4

$30: 3$ $12-13,16,38,42-43,46-49$

$13: 6$

128

13:13-18 88

30:4

$30: 5$

$30: 6$

$30: 7$

$30: 8$

$30: 9$

30:10

30:11

30:12

30:13

30:14

$30: 15$

31

$31: 28$ $51,58,60-61$ 43-44, 46, 51 $43-44,51$ 43,51 $43,45-46$ 43,51 $43,45-46$ 43-44 43,51 43,51 43,51 $13: 16$ $13: 17-18$ 80 105

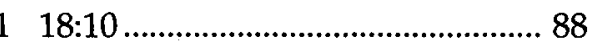

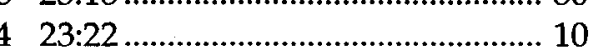

26:14 ................................................ 28

\section{Joshua}

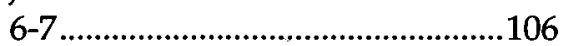

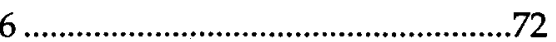

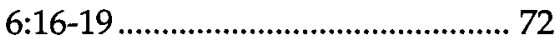

6:17-19 …....................................... 72

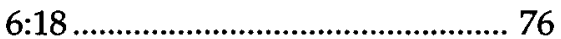

6:19 …................................... 75, 77

6:24 ....................................... 75, 100

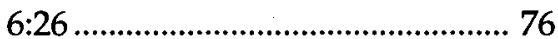

7:23-24 …........................................ 75

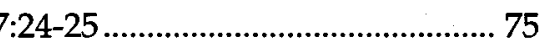

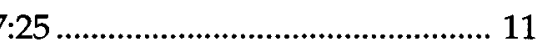

$43 \quad 8: 28 \ldots \ldots \ldots \ldots \ldots \ldots \ldots \ldots \ldots \ldots \ldots . . . . . \ldots 5-76,80,85$

$86,90,108$

$9: 15-27$ 
Index

11

11:11

11:13

Judges

1:17

5:16-17

$5: 23$

8:1-3

11

11:35

11:36

12:1-6

19:30

21

21:1-14

21:1-7

21:5

21:8

21:11

I Samuel

1:11

1:21

1:26

2:12-17

11:5-10

14:24

14:45

15 .

15:14.

15:19

15:22-23

15:33

17:55

20:3

20:8

25:22

25:26

31:2

31:11-13

II Samuel

14:32

21:6.
.75

75-76

75-76

2:2

2:4

2:6

90

.90

. .88

149

89

.90

89

108,145

89

145

$89-91,106$

90

76

(3)

9

9

9

131

30,32

90

$10,93,107$

149

.75

75

75

75

75

131

131

132

137

132

149

90

132

77
I Kings

5:18 ….............................................. 77

I Kings

4:30 …………………………….... 132

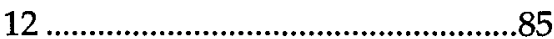

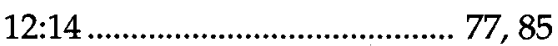

12:19 …......................................... 77

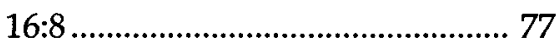

18:14-15 …………………………..... 77

19:11 …..................................... 71-72

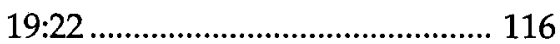

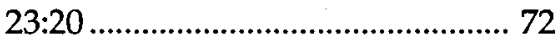

Isaiah

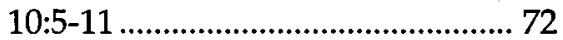

29:13 ….......................................... 22-23

30:33 …...................................... 72

34:1-8 ....................................... $72-73$

37:11 …….................................... 71-72

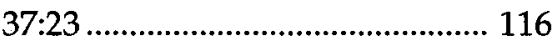

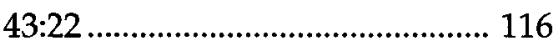

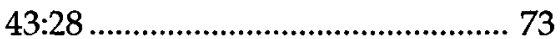

Jeremiah

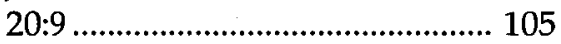

25:9 …....................................... 73

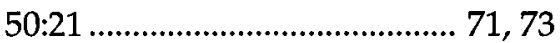

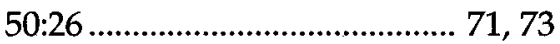

51:3 …........................................ 71, 73

Ezekiel

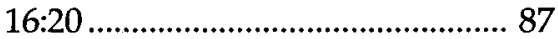

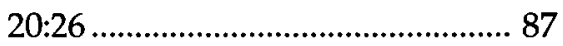

22:19-22 ….............................. 100

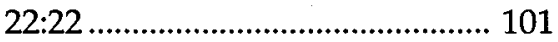

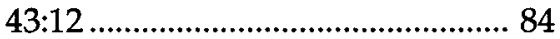

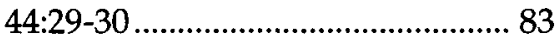

$44: 29 \ldots \ldots \ldots \ldots \ldots \ldots \ldots \ldots \ldots \ldots \ldots . . . . .15-86,108$

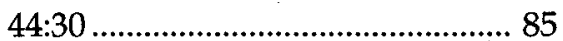

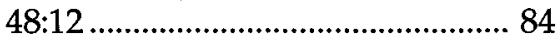


Amos Ezra

8:14 $127 \quad 1: 8$ 156

Micah $7: 21$ 156

4:13

$72 \quad 10: 8$ $70,95,107$

$7: 2$

31-32 Nehemiah

Jonah

10:35

1:16.

9 II Chronicles

Zechariah 20:23 71-72

14:11 $73 \quad 24: 14$. 78

Malachi

3:24. 73

Psalm

22:26

35:16

$37: 15$

$56: 13$

61:6-9

95:7.

95:11

116:17-18

.9

116

100

9 I

\section{Apocrypha and Pseudepigrapha} Tobit

132:1-5

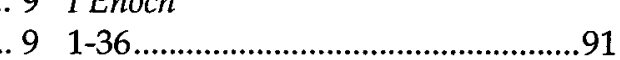
28

132:2

137:5. 150 150

Song of Songs

2:7. 127

Ecclesiastes

5:1 116 5:5-6 116

\section{Lamentations}

2:16

Daniel

6

$6: 8$

$6: 9$

6:10

6:13

6:14 139

4:17 28

\section{Ecclesiasticus}

30:18.

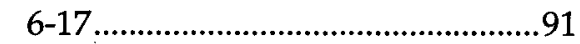

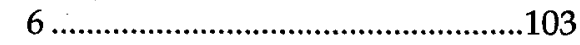

6:1-6 ................................. 91-92, 109

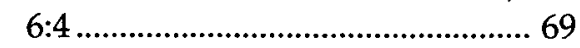

Testament of Reuben

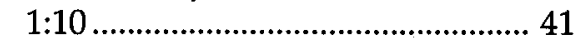

Testament of Judah

15:4 ..................................................... 41

Testament of Naphtali

$7: 4$

Testament of Zebulun

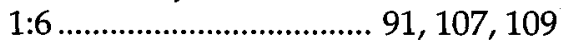

IV Esdras

9:24 ...................................................... 41

41

Jubilees

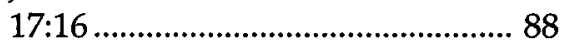

$6: 16$

51

$10: 3$ 


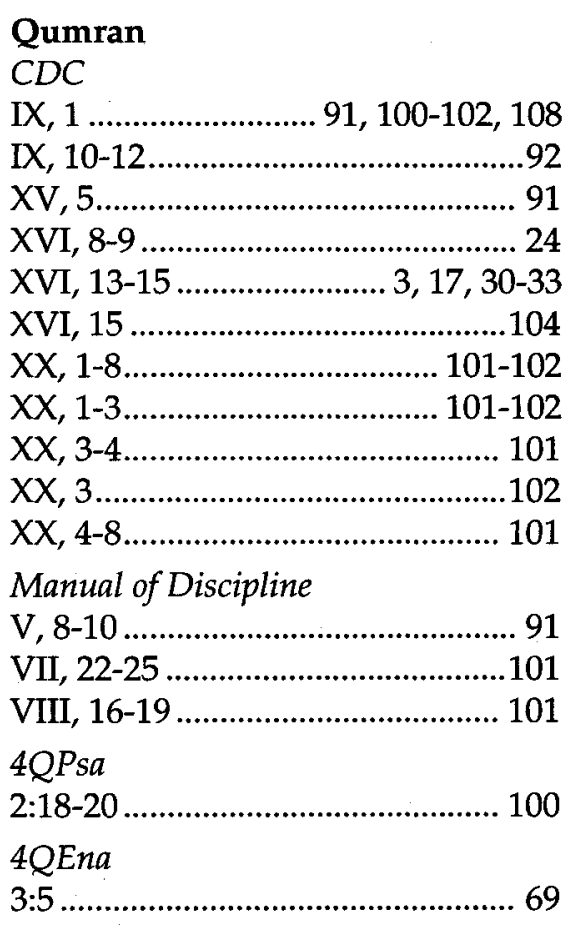

\section{Hellenistic Jewish Writers}

Philo, De Specialibus Legibus

II, 2 .

II, 5 .

II, 9 .

II, 12-13

II, 15.

II, 17 .

III, 83

Philo, Hypothetica

7.3-5

7.3

7.3-4 39 3, 33-35, 154-155 34-35 34
Philo, De Vita Mosis

I, 17 .. .115

Josephus, Antiquities

II, 228 .

$\mathrm{V}, 1$

$.11,78$

$\mathrm{V}, 2,12$ 154

Josephus, Contra Apion

I, 167 .. .39

24 Josephus, War

II, 145 ... 115

II, 175 . 10

New Testament

Matthew

5:36 139

15.

15:3-9. 26

$91 \quad 15: 3-6$ 17-18 101 15:3-5 122

101 15:5 $3,17-18,26$ 15:6-7. 22 23:16-22 ................... 18, 26-27, 38-39 26:34-35 _........................................ 94

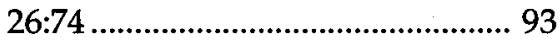
$27: 6$ 10

Mark 7 151

$7: 6-7$ 22 $7: 9-13$ 17,26 $7: 11$ $7: 12$ $3,16-17,29,31,34,38$ (4:

14:30-31 _......................................... 94 14:71 93,102 Luke 21:5 103 105 John 9:22 105

$12: 42$ $16: 2$ 
Acts

4:32-35

$4: 32$

4:35

23

23:12-14 $69,92,108$

Romans

9:3

15:26

I Corinthians

5

12:1

$12: 2-3$

12:2

12:3

12:4-31

13

14

14:1-25

14:25-40

14:39

15

16:1-21

16:22

16:23-24

II Corinthians

3:15

9:13 98, 105-106 124

105

106 105 106 106 106 .106 . .106 106 106 106 106 106 105 106

Galatians

1:8 105

\section{Church Fathers}

Eusebius, Praeparatio Evangelica

7.3-7.5

Origen, Commentary to Matthew 15:1

Tertullian, Apology XXXII.

Classical Authors

Iliad

$15,37-39$.

\section{Cratinus}

Kock, fragment 231 133

Sosicrates

Jacoby 461, fragment 3 133 Euripides

Helen, 1. 835 133

Aristophanes, Birds

1. 194 134

1. 521 134,136

Scholia to Plato's Apology $22 \mathrm{a}$

Scholia to Plato's Republic

398e 133

Scholia to Plato's Phaedrus

$228 \mathrm{~b}$ 133

Scholia to Aristophanes Birds

1. 521 . 136

Zenobius v 81

Philostratus, Vita Apollonius vi...

Callimachus, Lock of Berenice

fragment 3

Plutarch, Moralia

669e-671c

Athenaeus of Nacritus

$2,66 \mathrm{c}$

Catullus

66

Aeneid

4:357

9:300

Horace, Odes

$2,8,5-6$

Pliny the Younger, Epistles

II, 20.

Juvenal

$133,140 \mathrm{VI}, 16$ 137-138 
XIII, 77-83

138-139 Mishnah Taanit

XIII, 84-85

..138 3:8

Martial

IX, 48, 2 .138

Mishnah Hagigah

Ovid, Amores

II, 16,44 . 138

$1: 8$ $150-153,159,162-163$

Mishnah Ketubot

Ovid, Tristia

$\mathrm{V}, \mathrm{iv}, 45$.

$7: 10$ 34

Ovid, Ex Ponto

138 Mishnah Nedarim

$3,3,68$

$1: 1$

$66,98,103-104$

$138 \quad 1: 2$

$5,11,14,111-112,121$

Ovid, Heroides

$1: 3-4$.

$11,13,37-38,135$

III, 103-110

138,140

Suetonius, Caligula,142

27.

Silius Italicus

8, 106

138-140

Digesta

XII, 3-5. 142

$1: 3$ 124

$2: 1$

$2: 2$ 25

$2: 3$ 67,103

$2: 4$ $70,87,104$

$2: 5$ $70,103-104,135-136$ 3 7, 152-153, 161-164

Tannaitic Literature

$3: 1$ 160

$3: 2$ 150

Scroll of Fasting. 4, 51-55

Mishnah Berakhot

2:1 161

5:1 161

Mishnah Kilayim

$3: 3$

$3: 4$

$3: 5$

$4: 2$ $13-14,25,150,160$

1:8 125

Mishnah Sheviit

9:1 125

$4: 4$ $13-14,25,150,160$

$5: 3$

$5: 4$ 37,157

Mishnah Shabbat

24:5

171

Mishnah Sheqalim

5:2 156

$5: 6$ $144,150,160,164$

$6: 1$ 37

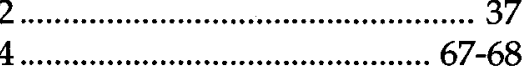

Mishnah Betzah

5:2

$7: 6$ $70,98-99,105$

$7: 9$ 15,37

Mishnah Rosh Hashanah

$8: 7$ ... 14

9 . 9:1 11,14 14-15

3:7

9:2

15,159

171

9:3

.

Mishnah Megillah

9:7 16

$151 \quad 9: 9$

14-15

4:3

11:2 151,163 158 
Mishnah Nazir

1:1

2:1-2

2:1

$5: 1-2$

$5: 1$

5:3

Mishnah Gittin

$4: 7$

$4: 8$

7:5

Mishnah Qiddushin

1:6

Mishnah Sanhedrin

1:1-3

$3: 2$

9:6

Mishnah Shevuot

3:1

$3: 6$

$3: 7$

$4: 13$

$7,26,114,145-146$

Mishnah Avodah Zarah

3:7

Mishnah Eduyot

2:2

119-120

10,157

157-158

134-135, 141

11,78

114,145

Mishnah Zevahim

$1: 2$

$3: 2$

Mishnah Arakhin

5

$6: 2$

$8: 1$

8:6

Mishnah Middot

2:2

Mishnah Kelim

25:9

Mishnah Makhshirin

6:1
143

120

$24 \quad 5: 3$

$67 \quad 7: 3$
-

Tosefta Nazir

$1: 1$ 114

120

Mishnah Uqtsin

Tosefta Hagigah $1: 9$ $150-153,162-163$ Tosefta Nedarim

$1: 2-3$ 13,37

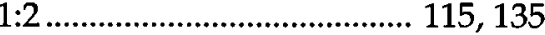

$1: 3$

106,124

$1: 4$ $47-48,61$ 87,153

$2: 9$ 38

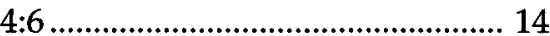

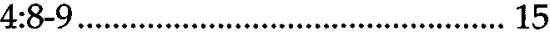

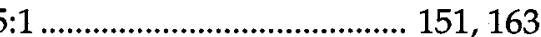

103

14

11.14

Tosefta Sotah

$97 \quad 6: 1$

134,142

Tosefta Gittin

$151 \quad 4: 3$

152

151 Tosefta Sanhedrin

$5: 1$

.10 Tosefta Shevuot

$34 \quad 2: 16$

Tosefta Avodah Zarah

3:7

Tosefta Horayot

2:10. 156

151

Tosefta Zevahim

12:17

11,78 134-136, 141 
Tosefta Menahot

PT Taanit

5:6

151 2:13, 66a 55

13:21 156

$4: 1,67 \mathrm{~b}$

Tosefta Arakhin

$4: 11,69 \mathrm{c}$

$4: 9$

155 PT Megillah

4:34

86 1:6, 70c 55

Tosefta Parah $4: 8,75 \mathrm{c}$

2:1 120 PT Hagigah

Tosefta Niddah

$1: 8,76 \mathrm{c}$ 163

4:6 120 PT Moed Qatan

Mekhilta Pisha $3: 1,81 \mathrm{c}-\mathrm{d}$

16

Mekhilta Bahodesh

$3: 1,81 \mathrm{~d}$ 97-98

7

24 13:2, 35d 37

Sifra Shemini PT Nedarim

Chapter 11, paragraphs 3-4 57

Sifra Zavim

Parashah 5, paragraph 7 . .57

Sifra Emor

Chapter 12, section 2 57

Sifre Bemidbar

8

153

Sifre Zuta

Numbers 30:2....... 46-47, 49, 52, 163

Numbers 30:3. $12-13,16$

\section{Palestinian Talmud}

PT Berakhot

7:2, 11b 161 PT Sotah

PT Shabbat $3: 4,18 \mathrm{~d}$ 57

$1: 1,2 b$ 156

PT Terumot

8:10, 46b .98

PT Yoma

$4: 4,19 \mathrm{c}$

PT Qiddushin

1:7,61a 24

PT Sanhedrin

$1: 1,38 \mathrm{c}$ 115

2:1,19d 115

$2: 8,20 \mathrm{c}$ 28 
PT Sheouot

3:5, 34c.

3:11, 34a

PT Horayot

3:2, 47a.

\section{Babylonian Talmud}

BT Berakhot

$12 \mathrm{a}$

$18 \mathrm{a}$

$24 \mathrm{~b}$

BT Shabbat

$92 \mathrm{~b}$

$94 \mathrm{~b}$

$101 \mathrm{~b}$

$115 \mathrm{~b}$

$128 \mathrm{a}$

$157 \mathrm{a}$

BT Eruvin

$34 \mathrm{a}$

$64 \mathrm{a}$

BT Pesahim

6b.

BT Yoma

$63 \mathrm{~b}$

BT Sukkah

$39 \mathrm{a}$

BT Betsah

38b

BT Taanit

$12 \mathrm{a}$

$23 \mathrm{a}$

BT Moed Qatan

$16 \mathrm{a}-17 \mathrm{~b}$.

$16 \mathrm{a}$

BT Hagigah

$10 \mathrm{a}$

BT Ketubot

$75 \mathrm{a}$
$75 b$

$2977 \mathrm{~b}$

24 BT Nedarim

$2 a$

$1155 b$

$10 \mathrm{a}$

$10 \mathrm{~b}$

$12 \mathrm{a}$

$13 a$

$14 a$

$16 \mathrm{~b}$

$20 \mathrm{a}$

$21 \mathrm{a}$ 56

114

115

120

125

171

$21 \mathrm{~b}$

$23 \mathrm{~b}$

$25 \mathrm{~b}$

$28 \mathrm{a}$

$35 a$

$64 a-b$.

$77 a$

$12577 \mathrm{~b}$

$12178 \mathrm{a}$

146

52

$6,112-113,115$

.114-115

.50

12

11-13, 38

65 153

$. .151,163$

BT Nazir

169

$9 a$

$1032 a$

52

161

153

BT Sotah

$11536 \mathrm{~b}$ 164

BT Gittin

$11546 a$

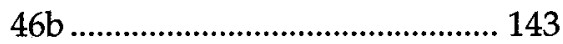

52-55 BT Qiddushin

$975 \mathrm{~b}$

$32 \mathrm{~b}$ 52

$59 \mathrm{~b}$

151

94

$.96,106$

BT Bava Qamma

$48 \mathrm{~b}$ 56 150

BT Bava Metsi'a

$82 \mathrm{~b}$ 56

$84 a$

...98 
Bava Batra

$120 \mathrm{~b}$

BT Sanhedrin

38 a

$65 \mathrm{~b}$

BT Shevuot

$20 \mathrm{a}-\mathrm{b}$

$20 \mathrm{a}$

$20 \mathrm{~b}$

$21 \mathrm{a}$

$22 a-b$

$22 \mathrm{a}$

$25 \mathrm{a}$

$26 \mathrm{a}$

$27 \mathrm{~b}$

$36 \mathrm{~b}$

BT Avodah Zarah

$7 a$

$11 \mathrm{a}$

BT Menahot

$64 \mathrm{a}$ .57

$68 \mathrm{~b}$

BT Hullin

$7 a$

$51 \mathrm{a}$

$93 a$

BT Arakhin

$23 \mathrm{a}$ 161

$27 \mathrm{a}$ .155

$29 \mathrm{a}$

BT Temurah

$3 \mathrm{~b}$. 24

\section{Midrash Aggadah}

Genesis Rabbah

41 . .104

$56: 4$ 88

60:3 149

91 142,161
Numbers Rabbah

Deuteronomy Rabbah

Shir Hashirim Rabbah

2:7 ................................................. 139

47 Pirke deRabbi Eliezer

38

$91,93,106$

Tanhuma Vayeshev .......... 91, 93, 106

Midrash Tehillim

10 ..............................................104 . 

140001 Approaches to Ancient Judaism I

140002 The Traditions of Eleazar Ben Azariah

140003 Persons and Institutions in Early Rabbinic Judaism

140004 Claude Goldsmid Montefiore on the Ancient Rabbis

140005 The Ecumenical Perspective and the Modernization of Jewish Religion

140006 The Sabbath-Law of Rabbi Meir

140007 Rabbi Tarfon

140008 Rabban Gamaliel II

140009 Approaches to Ancient Judaism II

$140010 \quad$ Method and Meaning in Ancient Judaism I

140011 Approaches to Ancient Judaism III

140012 Turning Point: Zionism and Reform Judaism

140013 Buber on God and the Perfect Man

$140014 \quad$ Scholastic Rabbinism

140015 Method and Meaning in Ancient Judaism II

140016 Method and Meaning in Ancient Judaism III

140017 Post Mishnaic Judaism in Transition

140018 A History of the Mishnaic Law of Agriculture:

Tractate Maaser Sheni

140019 Mishnah's Theology of Tithing

140020 The Priestly Gift in Mishnah: A Study of Tractate Terumot

140021 History of Judaism: The Next Ten Years

140022 Ancient Synagogues

140023 Warrant for Genocide

140024 The Creation of the World According to Gersonides

140025 Two Treatises of Philo of Alexandria: A Commentary on De Gigantibus and Quod Deus Sit Immutabilis

140026 A History of the Mishnaic Law of Agriculture: Kilayim

140027 Approaches to Ancient Judaism IV

140028 Judaism in the American Humanities I

140029 Handbook of Synagogue Architecture

140030 The Book of Mirrors

140031 Ideas in Fiction: The Works of Hayim Hazaz

140032 Approaches to Ancient Judaism V

140033 Sectarian Law in the Dead Sea Scrolls: Courts, Testimony and the Penal Code

$140034 \quad$ A History of the United Jewish Appeal: 1939-1982

140035 The Academic Study of Judaism

$140036 \quad$ Woman Leaders in the Ancient Synagogue

140037 Formative Judaism I: Religious, Historical, and Literary Studies

140038 Ben Sira's View of Women: A Literary Analysis

140039 Barukh Kurzweil and Modern Hebrew Literature

140040 Israeli Childhood Stories of the Sixties: Yizhar, Aloni, Shahar, Kahana-Carmon

140041 Formative Judaism II: Religious, Historical, and Literary Studies

140042 Judaism in the American Humanities II: Jewish Learning and the New Humanities
William S. Green

Tzvee Zahavy

William S. Green

Joshua B. Stein

S. Daniel Breslauer

Robert Goldenberg

Joel Gereboff

Shamai Kanter

William S. Green

Jacob Neusner

William S. Green

Howard R. Greenstein

Pamela Vermes

Anthony J. Saldarini

Jacob Neusner

Jacob Neusner

Baruch M. Bokser

Peter J. Haas

Martin S. Jaffee

Alan. J. Peck

Baruch M. Bokser

Joseph Gutmann

Norman Cohn

Jacob J. Staub

Winston/Dillon

Irving Mandelbaum

William S. Green

Jacob Neusner

Marilyn Chiat

Daniel C. Matt

Warren Bargad

William S. Green

Lawrence H. Schiffman

Marc L. Raphael

Jacob Neusner

Bernadette Brooten

Jacob Neusner

Warren C. Trenchard

James S. Diamond

Gideon Telpaz

Jacob Neusner

Jacob Neusner 
140043 Support for the Poor in the Mishnaic Law of Agriculture:

Tractate Peah

140044 The Sanctity of the Seventh Year: A Study of Mishnah

Tractate Shebiit

140045 Character and Context: Studies in the Fiction of Abramovitsh, Brenner, and Agnon

140046 Formative Judaism III: Religious, Historical,

and Literary Studies

140047 Pharaoh's Counsellors: Job, Jethro, and Balaam

in Rabbinic and Patristic Tradition

140048 The Scrolls and Christian Origins: Studies in the Jewish Background of the New Testament

140049 Approaches to Modern Judaism I

$140050 \quad$ Mysterious Encounters at Mamre and Jabbok

140051 The Mishnah Before 70

140052 Sparda by the Bitter Sea: Imperial Interaction in Western Anatolia

140053 Hermann Cohen: The Challenge of a Religion of Reason

140054 Approaches to Judaism in Medieval Times I

140055 In the Margins of the Yerushalmi: Glosses on the English Translation

140056 Approaches to Modern Judaism II

140057 Approaches to Judaism in Medieval Times II

$140058 \quad$ Midrash as Literature: The Primacy of Documentary Discourse

140059 The Commerce of the Sacred: Mediation of the Divine Among Jews in the Graeco-Roman Diaspora

140060 Major Trends in Formative Judaism I: Society and Symbol in Political Crisis

140061 Major Trends in Formative Judaism II: Texts, Contents, and Contexts

140062 A History of the Jews in Babylonia I: The Parthian Period

140063 The Talmud of Babylonia: An American Translation XXXII: Tractate Arakhin

140064 Ancient Judaism: Debates and Disputes

140065 Prayers Alleged to Be Jewish: An Examination

of the Constitutiones Apostolorum

140066 The Legal Methodology of Hai Gaon

140067 From Mishnah to Scripture: The Problem of the Unattributed Saying

140068 Halakhah in a Theological Dimension

140069 From Philo to Origen: Middle Platonism in Transition

140070 In Search of Talmudic Biography: The Problem of the Attributed Saying

140071 The Death of the Old and the Birth of the New: The Framework of the Book of Numbers and the Pentateuch

140072 The Talmud of Babylonia: An American Translation XVII: Tractate Sotah

140073 Understanding Seeking Faith: Essays on the Case of Judaism II: Literature, Religion and the Social Study of Judiasm

Jack Martin Balcer

William Kluback

David R. Blumenthal

Jacob Neusner

Marc Lee Raphael

David R. Blumenthal

Jacob Neusner

Jack N. Lightstone

Jacob Neusner

Jacob Neusner

Jacob Neusner

Jacob Neusner

Jacob Neusner

David Fiensy

Tsvi Groner

Jacob Neusner

David Novak

Robert M. Berchman

Jacob Neusner

Dennis T. Olson

Jacob Neusner

Jacob Neusner

140074 The Talmud of Babylonia: An American Translation

VI: Tractate Sukkah

140075 Fear Not Warrior: A Study of 'al tira' Pericopes

in the Hebrew Scriptures

Jacob Neusner

Edgar W. Conrad 
140076 Formative Judaism IV: Religious, Historical, and Literary Studies

140077 Biblical Patterns in Modern Literature

140078 The Talmud of Babylonia: An American Translation

I: Tractate Berakhot

140079 Mishnah's Division of Agriculture: A History and Theology of Seder Zeraim

140080 From Tradition to Imitation: The Plan and Program of Pesiqta Rabbati and Pesiqta deRab Kahana

140081 The Talmud of Babylonia: An American Translation XXIII.A: Tractate Sanhedrin, Chapters 1-3

140082 Jewish Presence in T. S. Eliot and Franz Kafka

140083 School, Court, Public Administration: Judaism and its Institutions in Talmudic Babylonia

140084 The Talmud of Babylonia: An American Translation XXIII.B: Tractate Sanhedrin, Chapters 4-8

140085 The Bavli and Its Sources: The Question of Tradition in the Case of Tractate Sukkah

140086 From Description to Conviction: Essays on the History and Theology of Judaism

140087 The Talmud of Babylonia: An American Translation XXIII.C: Tractate Sanhedrin, Chapters 9-11

140088 Mishnaic Law of Blessings and Prayers: Tractate Berakhot

140089 The Peripatetic Saying: The Problem of the Thrice-Told Tale in Talmudic Literature

140090 The Talmud of Babylonia: An American Translation XXVI: Tractate Horayot

Jacob Neusner Hirsch/Aschkenasy

Jacob Neusner

Alan J. Avery-Peck

Jacob Neusner

Jacob Neusner Melvin Wilk

Jacob Neusner

Jacob Neusner

Jacob Neusner

Jacob Neusner

Jacob Neusner Tzvee Zahavy

Jacob Neusner

Martin S. Jaffee

140091 Formative Judaism V: Religious, Historical, and Literary Studies

140092 Essays on Biblical Method and Translation

140093 The Integrity of Leviticus Rabbah

140094 Behind the Essenes: History and Ideology of the Dead Sea Scrolls

140095 Approaches to Judaism in Medieval Times III

140096 The Memorized Torah: The Mnemonic System of the Mishnah

$140097 \quad$ Knowledge and Illumination

140098 Sifre to Deuteronomy: An Analytical Translation I: Pisqaot 1-143. Debarim, Waethanan, Eqeb

Jacob Neusner

Edward Greenstein Jacob Neusner

Philip R. Davies David R. Blumenthal Jacob Neusner Hossein Ziai

Jacob Neusner

140099 Major Trends in Formative Judaism III: The Three Stages in the Formation of Judaism

Jacob Neusner

140101 Sifre to Deuteronomy: An Analytical Translation II: Pisqaot 144-357. Shofetim, Ki Tese, Ki Tabo, Nesabim, $H a^{\prime} a z i n u$, Zot Habberakhah

140102 Sifra: The Rabbinic Commentary on Leviticus

140103 The Human Will in Judaism

140104 Genesis Rabbah I: Genesis 1:1 to 8:14

140105 Genesis Rabbah II: Genesis 8:15 to 28:9

140106 Genesis Rabbah III: Genesis 28:10 to 50:26

140107 First Principles of Systemic Analysis

140108 Genesis and Judaism

140109 The Talmud of Babylonia: An American Translation

XXXV: Tractates Meilah and Tamid

Jacob Neusner

Neusner/Brooks

Howard Eilberg-Schwartz

Jacob Neusner

Jacob Neusner

Jacob Neusner

Jacob Neusner Jacob Neusner

140110 Studies in Islamic and Judaic Traditions I

Peter J. Haas

Brinner/Ricks 
140111 Comparative Midrash: The Plan and Program of Genesis

Rabbah and Leviticus Rabbah

140112 The Tosefta: Its Structure and its Sources

140113 Reading and Believing

140114 The Fathers According to Rabbi Nathan

140115 Etymology in Early Jewish Interpretation: The Hebrew

Names in Philo

140116 Understanding Seeking Faith: Essays on the Case of Judaism I:

Debates on Method, Reports of Results

140117 The Talmud of Babylonia: An American Translation

VII: Tractate Besah

140118 Sifre to Numbers: An American Translation and Explanation I: Sifre to Numbers 1-58

140119 Sifre to Numbers: An American Translation and Explanation II: Sifre to Numbers 59-115

140120 Cohen and Troeltsch: Ethical Monotheistic Religion and Theory of Culture

140121 Goodenough on the History of Religion and on Judaism

140122 Pesiqta deRab Kahana I: Pisqaot 1-14

140123 Pesigta deRab Kahana II: Pisqaot 15-28 and Introduction to Pesiqta deRab Kahana

140124 Sifre to Deuteronomy: Introduction

140126 A Conceptual Commentary on Midrash Leviticus Rabbah: Value Concepts in Jewish Thought

140127 The Other Judaisms of Late Antiquity

140128 Josephus as a Historical Source in Patristic Literature through Eusebius

140129 Judaism: The Evidence of the Mishnah

140131 Philo, John and Paul: New Perspectives on Judaism

and Early Christianity

140132 Babylonian Witchcraft Literature

140133 The Making of the Mind of Judaism: The Formative Age

140135

140136

140137

140138

140139

140140

Why No Gospels in Talmudic Judaism?

Torah: From Scroll to Symbol Part III: Doctrine

The Systemic Analysis of Judaism

Sifra: An Analytical Translation I

Sifra: An Analytical Translation II

140141

140142

140143

140144

140145

140146

Sifra: An Analytical Translation III

Midrash in Context: Exegesis in Formative Judaism

Sifra: An Analytical Translation IV

Oxen, Women or Citizens? Slaves in the System of Mishnah

The Book of the Pomegranate

Wrong Ways and Right Ways in the Study of Formative Judaism

Sifra in Perspective: The Documentary Comparison of the

Midrashim of Ancient Judaism

140147 Uniting the Dual Torah: Sifra and the Problem of the Mishnah

140148 Mekhilta According to Rabbi Ishmael: An Analytical

Translation I

140149 The Doctrine of the Divine Name: An Introduction to Classical Kabbalistic Theology

140150 Water into Wine and the Beheading of John the Baptist

140151 The Formation of the Jewish Intellect

140152 Mekhilta According to Rabbi Ishmael: An Introduction to Judaism's First Scriptural Encyclopaedia

Jacob Neusner

Jacob Neusner

Jacob Neusner

Jacob Neusner

Lester L. Grabbe

Jacob Neusner

Alan J. Avery-Peck

Jacob Neusner

Jacob Neusner

Wendell S. Dietrich

Neusner/Frerichs

Jacob Neusner

Jacob Neusner

Jacob Neusner

Max Kadushin

Alan F. Segal

Michael Hardwick

Jacob Neusner

Peder Borgen

Tzvi Abusch

Jacob Neusner

Jacob Neusner

Jacob Neusner

Jacob Neusner

Jacob Neusner

Jacob Neusner

Jacob Neusner

Jacob Neusner

Jacob Neusner

Paul V. Flesher

Elliot R. Wolfson

Jacob Neusner

Jacob Neusner

Jacob Neusner

Jacob Neusner

Stephen G. Wald

Roger Aus

Jacob Neusner

Jacob Neusner 
140153 Understanding Seeking Faith: Essays on the Case of Judaism III: Society, History, and Political and Philosophical Uses of Judaism

140154 Mekhilta According to Rabbi Ishmael: An Analytical Translation II

140155 Goyim: Gentiles and Israelites in Mishnah-Tosefta

140156 A Religion of Pots and Pans?

140157 Claude Montefiore and Christianity

140158 The Philosophical Mishnah III: The Tractates' Agenda:

From Nazir to Zebahim

Jacob Neusner

acob Neusner

Gary P. Porton

Jacob Neusner

Maurice Gerald Bowler

From Ancient Israel to Modern Judaism I: Intellect

in Quest of Understanding

140160 The Social Study of Judaism I

$140161 \quad$ Philo's Jewish Identity

140162 The Social Study of Judaism II

140163 The Philosophical Mishnah I: The Initial Probe

140164 The Philosophical Mishnah II: The Tractates' Agenda:

From Abodah Zarah Through Moed Qatan

140166 Women's Earliest Records

140167 The Legacy of Hermann Cohen

140168 Method and Meaning in Ancient Judaism

140169 The Role of the Messenger and Message in the Ancient Near East

140171 Abraham Heschel's Idea of Revelation

140172 The Philosophical Mishnah IV: The Repertoire

140173 From Ancient Israel to Modern Judaism II: Intellect

in Quest of Understanding

140174 From Ancient Israel to Modern Judaism III: Intellect

in Quest of Understanding

Jacob Neusner

Neusner/Frerichs/Sarna Jacob Neusner

Alan Mendelson

Jacob Neusner

Jacob Neusner

Jacob Neusner

Barbara S. Lesko

William Kluback

Jacob Neusner

John T. Greene

Lawerence Perlman

Jacob Neusner

Neusner/Frerichs/Sarna

Neusner/Frerichs/Sarna

140175 From Ancient Israel to Modern Judaism IV: Intellect

in Quest of Understanding

Neusner/Frerichs/Sarna

140176 Translating the Classics of Judaism: In Theory and In Practice

Jacob Neusner

140177 Profiles of a Rabbi: Synoptic Opportunities

in Reading About Jesus

140178 Studies in Islamic and Judaic Traditions II

140179 Medium and Message in Judaism: First Series

140180 Making the Classics of Judaism: The Three Stages

of Literary Formation

140181 The Law of Jealousy: Anthropology of Sotah

140182 Esther Rabbah I: An Analytical Translation

140183 Ruth Rabbah: An Analytical Translation

140184 Formative Judaism: Religious, Historical and Literary Studies

140185 The Studia Philonica Annual 1989

140186 The Setting of the Sermon on the Mount

140187 The Midrash Compilations of the Sixth and Seventh Centuries I

140188 The Midrash Compilations of the Sixth and Seventh Centuries II

140189 The Midrash Compilations of the Sixth and Seventh Centuries III

140190 The Midrash Compilations of the Sixth and Seventh Centuries IV

140191 The Religious World of Contemporary Judaism: Observations and Convictions

140192 Approaches to Ancient Judaism VI

140193 Lamentations Rabbah: An Analytical Translation

140194 Early Christian Texts on Jews and Judaism

140196 Torah and the Chronicler's History Work

Bruce Chilton

Brinner/Ricks

Jacob Neusner

Jacob Neusner

Adriana Destro

Jacob Neusner

Jacob Neusner

Jacob Neusner

David T. Runia

W.D. Davies

Jacob Neusner

Jacob Neusner

Jacob Neusner

Jacob Neusner

Jacob Neusner

Neusner/Frerichs

Jacob Neusner

Robert S. MacLennan

Judson R. Shaver 

From Literature to Theology in Formative Judaism

Judaism, Christianity, and Zoroastrianism

Eugene Weiner/Anita Weiner

in Talmudic Babylonia

140205 Tzedakah: Can Jewish Philanthropy Buy Jewish Survival?

Jacob Neusner

New Perspectives on Ancient Judaism I

Neusner/Borgen/Frerichs/Horsley

Christian Faith and the Bible of Judaism

ousner

Philo's Perception of Women

140210

Case Citation in the Babylonian Talmud: The Evidence

Tractate Neziqin

140211 The Biblical Herem: A Window on Israel's Religious Experience

Jacob Neusner

Dorothy Sly

140213 The Talmud of Babylonia: An American Translation

XXI.A: Tractate Bava Mesia Chapters 1-2

Eliezer Segal

Philip D. Stern

A.T. Kraabel

140214 The Talmud of Babylonia: An American Translation XXI.B: Tractate Bava Mesia Chapters 3-4

Jacob Neusner

140215 The Talmud of Babylonia: An American Translation

Jacob Neusner

140216 The Talmud of Babylonia: An American Translation
XXI.D: Tractate Bava Mesia Chapters 7-10

Jacob Neusner XXI.D: Tractate Bava Mesia Chapters 7-10

Jacob Neusner

140217 Semites, Iranians, Greeks and Romans: Studies in their Interactions

140218 The Talmud of Babylonia: An American Translation XXXIII: Temurah

Jonathan A. Goldstein

140219 The Talmud of Babylonia: An American Translation XXXI.A: Tractate Bekhorot Chapters 1-4

140220 The Talmud of Babylonia: An American Translation XXXI.B: Tractate Bekhorot Chapters 5-9

Jacob Neusner

Jacob Neusner

140221 The Talmud of Babylonia: An American Translation

Jacob Neusner XXXVI.A: Tractate Niddah Chapters 1-3

Jacob Neusner

140222 The Talmud of Babylonia: An American Translation XXXVI.B: Tractate Niddah Chapters 4-10

Jacob Neusner

140223 The Talmud of Babylonia: An American Translation XXXIV: Tractate Keritot

140224 Paul, the Temple, and the Presence of God

140225 The Book of the People

140226 The Studia Philonica Annual 1990

Jacob Neusner

140227 The Talmud of Babylonia: An American Translation XXV.A: Tractate Abodah Zarah Chapters 1-2

David A. Renwick

William W. Hallo

David Runia

140228 The Talmud of Babylonia: An American Translation XXV.B: Tractate Abodah Zarah Chapters 3-5

140230 The Studia Philonica Annual 1991

Jacob Neusner

Jacob Neusner

David Runia

140231 The Talmud of Babylonia: An American Translation XXVIII.A: Tractate Zebahim Chapters 1-3

Jacob Neusner

140232 Both Literal and Allegorical: Studies in Philo of Alexandria's

Questions and Answers on Genesis and Exodus

David M. Hay

140233 The Talmud of Babylonia: An American Translation

XXVIII.B: Tractate Zebahim Chapters 4-8

Jacob Neusner 
140234 The Talmud of Babylonia: An American Translation XXVIII.C: Tractate Zebahim Chapters 9-14

Jacob Neusner

140235 The Talmud of Babylonia: An American Translation XXIX.A: Tractate Menahot Chapters 1-3

Jacob Neusner

140236 The Talmud of Babylonia: An American Translation XXIX.B: Tractate Menahot Chapters 4-7

Jacob Neusner

140237 The Talmud of Babylonia: An American Translation XXIX.C: Tractate Menahot Chapters 8-13

140238 The Talmud of Babylonia: An American Translation XXIX: Tractate Makkot

140239 The Talmud of Babylonia: An American Translation XXII.A: Tractate Baba Batra Chapters 1 and 2

Jacob Neusner

Jacob Neusner

Jacob Neusner

Jacob Neusner XXII.B: Tractate Baba Batra Chapter 3

140241 The Talmud of Babylonia: An American Translation XXII.C: Tractate Baba Batra Chapters 4-6

140242 The Talmud of Babylonia: An American Translation XXVII.A: Tractate Shebuot Chapters 1-3

140243 The Talmud of Babylonia: An American Translation XXVII.B: Tractate Shebuot Chapters 4-8

140244 Balaam and His Interpreters: A Hermeneutical History of the Balaam Traditions

140245 Courageous Universality: The Work of Schmuel Hugo Bergman

140246 The Mechanics of Change: Essays in the Social History of German Jewry

140247 The Talmud of Babylonia: An American Translation XX.A: Tractate Baba Qamma Chapters 1-3

Jacob Neusner

Jacob Neusner

Jacob Neusner

John T. Greene

William Kluback

Steven M. Lowenstein

Jacob Neusner

140248 The Talmud of Babylonia: An American Translation XX.B: Tractate Baba Qamma Chapters 4-7

140249 The Talmud of Babylonia: An American Translation XX.C: Tractate Baba Qamma Chapters 8-10

Jacob Neusner

Jacob Neusner

140250 The Talmud of Babylonia: An American Translation XIII.A: Tractate Yebamot Chapters 1-3

Jacob Neusner

140251 The Talmud of Babylonia: An American Translation XIII.B: Tractate Yebamot Chapters 4-6

140252 The Talmud of Babylonia: An American Translation XI: Tractate Moed Qatan

140253 The Talmud of Babylonia: An American Translation XXX.A: Tractate Hullin Chapters 1 and 2

Jacob Neusner

Jacob Neusner

Tzvee Zahavy

140254 The Talmud of Babylonia: An American Translation XXX.B: Tractate Hullin Chapters 3-6

Tzvee Zahavy

140255 The Talmud of Babylonia: An American Translation XXX.C: Tractate Hullin Chapters 7-12

140256 The Talmud of Babylonia: An American Translation XIII.C: Tractate Yebamot Chapters 7-9

Tzvee Zahavy

Jacob Neusner

140257 The Talmud of Babylonia: An American Translation XIV.A: Tractate Ketubot Chapters 1-3

Jacob Neusner

140258 The Talmud of Babylonia: An American Translation XIV.B: Tractate Ketubot Chapters 4-7

140259 Jewish Thought Adrift: Max Wiener (1882-1950)

140260 The Talmud of Babylonia: An American Translation XIV.C: Tractate Ketubot Chapters 8-13

Jacob Neusner Robert S. Schine

Jacob Neusner 
140261 The Talmud of Babylonia: An American Translation XIII.D: Tractate Yebamot Chapters 10-16

140262 The Talmud of Babylonia: An American Translation XV. A: Tractate Nedarim Chapters 1-4

140263 The Talmud of Babylonia: An American Translation XV.B: Tractate Nedarim Chapters 5-11

140264 Studia Philonica Annual 1992

140265 The Talmud of Babylonia: An American Translation XVIII.A: Tractate Gittin Chapters 1-3

140266 The Talmud of Babylonia: An American Translation XVIII.B: Tractate Gittin Chapters 4 and 5

140267 The Talmud of Babylonia: An American Translation XIX.A: Tractate Qiddushin Chapter 1

140268 The Talmud of Babylonia: An American Translation XIX.B: Tractate Qiddushin Chapters 2-4

140269 The Talmud of Babylonia: An American Translation XVIII.C: Tractate Gittin Chapters 6-9

140270 The Talmud of Babylonia: An American Translation II.A: Tractate Shabbat Chapters 1 and 2

140271 The Theology of Nahmanides Systematically Presented

140272 The Talmud of Babylonia: An American Translation II.B: Tractate Shabbat Chapters 3-6

140273 The Talmud of Babylonia: An American Translation II.C: Tractate Shabbat Chapters 7-10

140274 The Talmud of Babylonia: An American Translation II.D: Tractate Shabbat Chapters 11-17

140275 The Talmud of Babylonia: An American Translation II.E: Tractate Shabbat Chapters 18-24

140276 The Talmud of Babylonia: An American Translation III.A: Tractate Erubin Chapters 1 and 2

140277 The Talmud of Babylonia: An American Translation III.B: Tractate Erubin Chapters 3 and 4

140278 The Talmud of Babylonia: An American Translation III.C: Tractate Erubin Chapters 5 and 6

140279 The Talmud of Babylonia: An American Translation III.D: Tractate Erubin Chapters 7-10

140280 The Talmud of Babylonia: An American Translation XII: Tractate Hagigah

140281 The Talmud of Babylonia: An American Translation IV.A: Tractate Pesahim Chapter I

140282 The Talmud of Babylonia: An American Translation IV.B: Tractate Pesahim Chapters 2 and 3

Jacob Neusner

Jacob Neusner

Jacob Neusner David T. Runia

Jacob Neusner

Jacob Neusner

Jacob Neusner

Jacob Neusner

Jacob Neusner

Jacob Neusner

David Novak

Jacob Neusner

Jacob Neusner

Jacob Neusner

Jacob Neusner

Jacob Neusner

Jacob Neusner

Jacob Neusner

Jacob Neusner

Jacob Neusner

Jacob Neusner

Jacob Neusner

140283 The Talmud of Babylonia: An American Translation

IV.C: Tractate Pesahim Chapters 4-6

Jacob Neusner

140284 The Talmud of Babylonia: An American Translation

IV.D: Tractate Pesahim Chapters 7 and 8

140285 The Talmud of Babylonia: An American Translation

IV.E: Tractate Pesahim Chapters 9 and 10

140286 From Christianity to Gnosis and From Gnosis to Christianity

Studia Philonica Annual 1993

140288

Diasporas in Antiquity

140289

The Jewish Family in Antiquity

Shaye J. D. Cohen, Ernest S. Frerichs

140290

The Place of Judaism in Philo's Thought

Shaye J. D. Cohen

Ellen Birnbaum 
140294 The Talmud of Babylonia: An American Translation

$$
\text { V. A: Tractate Yoma Chapters } 1 \text { and } 2
$$

Jacob Neusner

140295 The Talmud of Babylonia: An American Translation

V. B: Tractate Yoma Chapters 3-5

Jacob Neusner

140296 The Talmud of Babylonia: An American Translation

V. C: Tractate Yoma Chapters 6-8

140297 The Talmud of Babylonia: An American Translation XXII.D: Tractate Baba Batra Chapters Seven and Eight

140298 The Talmud of Babylonia: An American Translation XXII.E: Tractate Baba Batra Chapters Nine and Ten

Jacob Neusner

Jacob Neusner

Jacob Neusner David T. Runia

140299 The Studia Philonica Annual, 1994

140300 Sages, Stories, Authors, and Editors in Rabbinic Judaism

Richard Kalmin

140301 From Balaam to Jonah: Anti-prophetic Satire in the

David Marcus

140302 The History of Sukkot in the Second Temple and Rabbinic Periods

140303 Tasting the Dish: Rabbinic Rhetorics of Sexuality

Jeffrey L. Rubenstein

140304 The School of Moses: Studies in Philo and Hellenistic Religion

Michael L. Satlow

140305

The Studia Philonica Annual, 1995

John Peter Kenney

David T. Runia

140306 . The Talmud of Babylonia, An American Translation

Alan J. Avery-Peck IX, Tractate Rosh Hashanah

140307 Early Rabbinic Civil Law and the Social History of Roman Galilee: Hayim Lapin A Study of Mishnah Tractate Baba Mesia

140308 The Libes Briv of Isaac Wetzlar

140309 The Studia Philonica Annual, 1996

Morris M. Faierstein

140310 Rashbam's Commentary on Exodus: An Annotated Translation

140311 The Elijah Legends and Jehu's Coup

140312 The Studia Philonica Annual, 1997; Wisdom and Logos:

Studies in Jewish Thought in Honor of David Winston

140313 The Echoes of Many Texts: Reflections on Jewish and Christian

Traditions, Essays in Honor of Lou H. Silberman

William G. Dever and

J. Edward Wright

140315 Kol Nidre: Studies in the Development of Rabbinic

Votive Institutions

Moshe Benovitz

\section{Brown Studies on Jews and Their Societies}

145001 American Jewish Fertility

145002 The Impact of Religious Schooling: The Effects of Jewish Education Upon Religious Involvement

145003 The American Jewish Community

145004 The Naturalized Jews of the Grand Duchy of Posen in 1834 and 1835

145005 Suburban Communities: The Jewishness of American Reform Jews
Calvin Goldscheider

Harold S. Himmelfarb

Calvin Goldscheider

Edward David Luft

Gerald L. Showstack 


\section{Brown Studies in Religion}

$147001 \quad$ Religious Writings and Religious Systems I

147002 Religious Writings and Religious Systems II

147003 Religion and the Social Sciences
Jacob Neusner, et al Jacob Neusner, et al Robert Segal 